Universidade de SÃo PAUlo

FACUldade DE Filosofia, LeTRAS E CiênCIAS Humanas

DEPARTAMENTO DE LINGUÍSTICA

A concordância verbal nas comunidades quilombolas de Alcântara (MA): uma contribuição para a discussão sobre o contato linguístico no português brasileiro

— versão corrigida -

WÂNia Miranda ARaúJo da SiLva

São Paulo

2017 
UNIVERSIDAdE DE SÃo PAUlO

FaCuldade De Filosofia, Letras E CiÊnCIAs Humanas

DEPARTAMENTO DE LINGUÍSTICA

\title{
A concordância verbal nas comunidades quilombolas de Alcântara (MA): uma contribuição para a discussão sobre o contato linguístico no português brasileiro
}

\author{
WÂNia Miranda ARAúJO DA SILVA
}

TESE De Doutorado APRESENTAdA AO PROGRAMA DE PÓS-GRAdUAÇÃO EM SEMIÓTICA E LiNGUÍSTICA GERAL DO DEPARTAMENTO DE LINGUÍSTICA DA FACULDADE DE FILOSOFIA, LETRAS E CIÊNCIAS HUMANAS DA UNIVERSIDADE DE SÃo PAUlo PARA A OBTENÇÃo DO TÍTULO DE DOUTOR EM LINGUÍSTICA.

OrIENTADOR: PROF. DR. MARCOS LOPES

São Paulo

2017 
Autorizo a reprodução e divulgação total ou parcial deste trabalho, por qualquer meio convencional ou eletrônico, para fins de estudo e pesquisa, desde que citada a fonte.

Catalogação na Publicação

Serviço de Biblioteca e Documentação

Faculdade de Filosofia, Letras e Ciências Humanas da Universidade de São Paulo

Miranda, Wânia

A concordância verbal nas comunidades quilombolas de Alcântara (MA) : uma contribuição para a discussão sobre o contato linguístico no português brasileiro / Wânia Miranda ; orientador Marcos Lopes. - São Paulo, 2017 .

$230 \mathrm{f}$.

Tese (Doutorado)- Faculdade de Filosofia, Letras e Ciências Humanas da Universidade de São Paulo. Departamento de Linguística. Área de concentração: Semiótica e Lingüística Geral.

1. Contato Linguístico. 2. Comunidades

Quilombolas. 3. Concordância Verbal. 4. Português Brasileiro. 5. Maranhão. I. Lopes, Marcos, orient. II. Título. 


\section{Agradeço...}

Ao Marcos Lopes, por ter sido um excelente orientador, pela compreensão, paciência e pela dedicação em todos esses anos, especialmente por sempre acreditar em mim.

Ao Departamento de Linguística por ter financiado a viagem de campo.

À Capes pelo auxílio financeiro.

Aos professores do Departamento de Linguística que contribuíram para a minha formação.

À Prof ${ }^{a}$ Margarida Petter, um exemplo de pessoa, professora e pesquisadora, sempre muito atenciosa e disposta a me ajudar.

À Prof ${ }^{a}$ Evani Viotti, por seus valorosos conselhos tanto no mestrado quanto no doutorado.

À Prof ${ }^{a}$ Esmeralda Negrão, sempre tão atenciosa e interessada nas pesquisas desenvolvidas pelos alunos da pós.

Aos funcionários do Departamento de Linguística, Robson, Denise e, especialmente, Érica.

Ao Eduardo pela amizade de sempre.

À Vanessa por quase uma década de amizade que, apesar da distância, continua a mesma.

A tantos outros que fizeram parte desse caminho, de maneira especial Renata, Kamunjin e Laís Katarine.

À Ana Stela Cunha pelas dicas sobre a viagem de campo e sobre o Maranhão e pelos contatos estabelecidos.

Aos moradores das comunidades de Mamuna e Itamatatiua pela recepção e acolhimento, principalmente Ivana, dona Eloisa, dona Neide e dona Ceci, em Itamatatiua e dona Militina, em Mamuna.

Ao Sérvulo Borges, o Borjão, pelo acolhimento em Alcântara e por ter acreditado na minha pesquisa e ter possibilitado a minha estadia nas comunidades.

Ao Bruno David pela companhia, mesmo que breve, em Alcântara e em Mamuna.

A Rildo Pinto e Alberto Pereira pela recepção em Itapecuru-Mirim.

À Ana Stela Cunha pelo apoio.

Aos meus pais, por terem incentivado e apoiado minhas decisões em relação à vida acadêmica.

Ao Yuri, meu filho querido, pela compreensão e paciência.

Aos meus irmãos, Wanny, Wellington e, é claro, Flávia, por entenderem que nem sempre eu podia estar presente.

Ao Saulo, meu companheiro, por ter me acompanhado e me apoiado nessa jornada. 
Todo povo colonizado - isto é, todo povo no seio do qual nasceu um complexo de inferioridade devido ao sepultamento de sua originalidade cultural - toma posição diante da linguagem da nação civilizadora [...] quanto mais assimilar os valores culturais da metrópole, mais o colonizado escapará de sua selva. Quanto mais ele rejeitar sua negridão, seu mato, mais branco será.

Frantz Fanon

As mulheres negras tiveram que desenvolver uma visão mais ampla da nossa sociedade, mais do que, talvez, qualquer outro grupo. Elas tiveram de compreender os homens brancos, as mulheres brancas e os homens negros. E elas tiveram de se compreender. Quando uma mulher negra conquista uma vitória é um ganho para praticamente cada segmento da sociedade.

Angela Davis 


\section{Resumo}

A presente tese realiza uma descrição e análise da marcação de terceira pessoa de plural nas comunidades quilombolas de Mamuna e Itamatatiua, localizadas em Alcântara (MA).

Esta marcação está no centro dos debates sobre a formação do português brasileiro, ora sendo tomada para explicar a deriva (Naro \& Scherre, 2007), ora para explicar o contato linguístico (Lucchesi et al., 2009; Silva, 2005, entre outros).

Esta pesquisa parte do princípio de que o contato ocorrido na época colonial entre o português trazido para o Brasil àquela época, as diferentes línguas africanas trazidas para cá, especialmente as línguas bantas (LBs), e as diferentes línguas indígenas existentes neste território, é o responsável pelas particularidades do português falado no Brasil.

Nesse sentido, as especificidades da marcação de terceira pessoa das comunidades alcantarenses podem ser explicadas a partir do contato linguístico estabelecido na formação dessas comunidades. O plural de terceira pessoa em Mamuna e Itamatatiua traz um terceiro tipo de marcação, que emerge a partir do processo fonológico de redução dos ditongos nasais pós-tônicos finais. Esta marcação revela-se como a mais produtiva não só em termos quantitativos, mas também por aparecer em contextos distintos aos de outras comunidades, como verbos no presente do indicativo, verbos de segunda conjugação e verbos irregulares.

Os processos fonológicos para evitar encontros vocálicos das LBs e o contexto final átono poderia explicar essa redução, apontada por diferentes autores como característica da fala de pretos (Mendonça, 1933; Raimundo, 1933, entre outros).

Adicionalmente, a ecologia externa de formação das comunidades alcantarenses poderia ter ajudado não apenas na manutenção desse final reduzido, mas na sua reinterpretação como morfema plural de terceira pessoa, bem como na sua expansão para contextos nos quais uma redução fonológica para uma vogal posterior não seria prevista no português brasileiro.

Palavras-chave: concordância verbal; contato de línguas; comunidades quilombolas; Maranhão. 


\begin{abstract}
This thesis presents a linguistic description and analysis of the third person plural mark in the Quilombola communities of Mamuna and Itamatatiua located in Alcântara (MA). This mark is in centering of debates about formation of Brazilian Portuguese and may be used to explain linguistic drift and language contact (Naro \& Scherre, 2007), (Lucchesi et al., 2009; Silva, 2005, among others).

This research assumes that linguistic contact between the Portuguese brought to Brazil in the colonial era, different African languages, especially Bantu languages (LBs), and different Native Brazilian languages spoken in the territory, is responsible for peculiarities of the Portuguese spoken in Brazil.

In this sense, specificities of the third person plural of Alcântara communities can be explained by linguistic contact established in formation of these communities. These third person plural in Mamuna and Itamatatiua have a third type of plural that emerges from the phonological process of reduction of nasal diphthongs in a final post-tonic position which proves to be the most productive in quantitative terms that appear in different contexts, i.e. verbs in present indicative, verbs of second conjugation and irregular verbs.

The phonological processes to avoid vowel encounters of LBs and final unaccented context could explain the reduction that characterize black speech or "fala de pretos", as pointed out by different authors (Mendonça, 1933; Raimundo, 1933 among others).

In addition, the external ecology of Alcântara communities's formation could have helped not only maintain the final reduced mark but in its reinterpretation as plural morpheme of third person, as well as its expansion into contexts in which phonological reduction for posterior vowel would not be anticipated in Brazilian Portuguese.
\end{abstract}

Key words: verbal agreement; language contact; quilombola communities; Maranhão. 


\section{Lista de abreviações}

$\begin{array}{ll}\text { 1SG/2SG/3SG } & 1^{\mathrm{a}} / 2^{\mathrm{a}} / 3^{\mathrm{a}} \text { pessoa do singular } \\ \text { 1PL/2PL/3PL } & 1^{\mathrm{a}} / 2^{\mathrm{a}} / 3^{\mathrm{a}} \text { pessoa do plural } \\ \text { AUX } & \text { auxiliar } \\ \text { DEM } & \text { demonstrativo } \\ \text { DET } & \text { determinante } \\ \text { DU } & \text { dual } \\ \text { IMPF } & \text { imperfeito } \\ \text { NEG } & \text { partícula de negação } \\ \text { NOMZ } & \text { nominalizador } \\ \text { OBJ } & \text { objeto } \\ \text { PFV } & \text { perfectivo } \\ \text { PL } & \text { plural } \\ \text { POSS } & \text { possessivo } \\ \text { PREP } & \text { preposição } \\ \text { PST } & \text { passado } \\ \text { PRON } & \text { pronome } \\ \text { RSM } & \text { resumptivo } \\ \text { SC } & \text { concordância sujeito } \\ \text { T } & \text { pronome tônico }\end{array}$




\section{Sumário}

Resumo vii

Abstract viii

Lista de abreviações $\quad$ ix

1 Introdução 1

2 Metodologia $\quad 7$

2.1 Primeiros dados . . . . . . . . . . . . . . . 7

2.1.1 Dos fenômenos inicialmente estudados . . . . . . . 9

2.1.1.1 Marcação de número . . . . . . . . . . . . . 9 9

2.1.1.2 Marcação de gênero . . . . . . . . . . . . . 15

2.2 Trabalho de campo . . . . . . . . . . . . . . . . . . . 24

2.3 Transcrição . . . . . . . . . . . . . . . . . . 28

2.3.1 Fenômenos escolhidos . . . . . . . . . . . 30

2.4 Breves considerações . . . . . . . . . . . . . . 31

3 O contato linguístico e o contexto histórico de formação do PB 32

3.1 O contato linguístico . . . . . . . . . . . . 32

3.1.1 Evolução das línguas como especiação . . . . . . . . 33

3.1.2 De volta à História Linguística do português brasileiro 36

3.2 Contexto histórico da formação do PB . . . . . . . . . . . 38

3.3 O contato no português brasileiro . . . . . . . . . . . . . 46

3.4 Considerações do capítulo . . . . . . . . . . . . . 57

4 Alcântara e a ecologia maranhense $\quad \mathbf{6 0}$

4.1 A ecologia maranhense . . . . . . . . . . . . . . . 60 60

4.2 Quilombos .................... 70

4.2.1 Os quilombolas na Balaiada . . . . . . . . . . . 74

4.3 Alcântara ..................... . 76 
4.4 Itamatatiua . . . . . . . . . . . . . . . . . 81

4.5 Mamuna . . . . . . . . . . . . . . . . . . 85

4.6 Consideraçõos do capítulo . . . . . . . . . . . . . . 89

5 Concordância Verbal de Terceira Pessoa do Plural 93

5.1 Português brasileiro e português europeu . . . . . . . . . . . 94

5.2 PB, PE e outras variedades de português . . . . . . . . . . . . . 102

5.3 Português de Moçambique e português de Angola . . . . . . 106

5.4 A CV nas variedades urbanas do português brasileiro . . . . 111

5.5 A CV em variedades não urbanas do português brasileiro . . 113

5.6 Considerações do capítulo . . . . . . . . . . . . . . . . 117

6 Concordância Verbal de 3PP nas Comunidades de Mamuna e Ita$\begin{array}{ll}\text { matatiua } & 120\end{array}$

6.1 Origem da variação na concordância verbal . . . . . . . . . . 121

6.2 Marcação padrão versus não padrão . . . . . . . . . . . . . 123

6.3 Introduzindo os dados . . . . . . . . . . . . . . . 128

6.4 Marcação intermediária . . . . . . . . . . . . . . . . . . 131

6.4.1 Marcação intermediária no passado . . . . . . . . . . 132

6.4.2 Marcação intermediária no presente . . . . . . . . . 137

6.5 Consideraçõos do Capítulo . . . . . . . . . . . . . . . 142

7 Reanálise da marca de concordância da 3PP $\quad 144$

7.1 Reinterpretação da marcação intermediária . . . . . . . . . . 144

7.2 Marcação com verbos de segunda conjugação e com verbos irregulares . . . . . . . . . . . . . . . . 150

7.2.1 O contato com as línguas africanas e a redução final do verbo . . . . . . . . . . . . . . 155

7.3 Marcação com sujeitos no singular . . . . . . . . . . . . . . 162

7.3.1 Mamuna e Itamatatiua . . . . . . . . . . . . . . . 165

7.4 Considerações do Capítulo . . . . . . . . . . . . . 169

8 Sujeitos coletivos $\quad 171$

8.1 Considerações teóricas . . . . . . . . . . . . . . . . . 171

8.2 Sujeitos coletivos nas comunidades alcantarenses . . . . . . 177

8.3 Considerações do Capítulo . . . . . . . . . . . . . . . . . 184

9 Considerações Finais $\quad 185$

$\begin{array}{ll}\text { Referências } & 188\end{array}$ 
$\begin{array}{ll}\text { Anexos } & 205\end{array}$

Anexo I - Mapas 206

Anexo II - Carta de Alcântara sobre a cessão da Base Espacial aos EUA 


\section{Lista de Tabelas}

3.1 Total de africanos que desembarcaram no Brasil de 1580 a 169040

3.2 Total de africanos que desembarcaram no Brasil de 1691 a 175040

3.3 Total de africanos que desembarcaram no Brasil de 1751 a 180840

3.4 Total de africanos que desembarcaram no Brasil de 1808 a 185041

3.5 Total de africanos que desembarcaram no Brasil de 1500 a 187542

4.1 População Livre e Escrava no Maranhão - 1821 . . . . . . . . 65

4.2 População do Maranhão 1798 - 1872 . . . . . . . . . . . . . 65

4.3 Porcentagem de trabalhadores livres e escravizados nas diferentes profissões .................... 67

5.1 Concordância sujeito/verbo - PB/PE . . . . . . . . . . . 95

5.2 Concordância sujeito/verbo - PB/PE . . . . . . . . . . . 100

5.3 Concordância sujeito/verbo - PB/PE . . . . . . . . . . . . . 101

5.4 Concordância sujeito/verbo - PB/PE/PST . . . . . . . . . . 102

5.5 Concordância sujeito/verbo - PB/PE/PST . . . . . . . . . . . 104

5.6 Concordância sujeito/verbo - PE/PST/PB/PL . . . . . . . . 105

5.7 Concordância sujeito/verbo - Normas popular e culta (BA) . 112

5.8 Concordância verbal em Cinzento, Morrinhos e Poções - PB (BA) . . . . . . . . . . . . . . . . . 114

5.9 Continuum de marcação da concordância verbal em diferentes variedades do português brasileiro . . . . . . . . . . . . 115

5.10 Concordância sujeito/verbo em variedades do português brasileiro. . . . . . . . . . . . . . . . . . 119

6.1 Variação na marcação de CV na comunidade de Itamatatiua 129

6.2 Variação na marcação de CV na comunidade de Mamuna . . 129

6.3 Marcação intermediária somada à marcação padrão - Itamatatiua . . . . . . . . . . . . . . . . 130

6.4 Marcação intermediária somada à marcação padrão - Mamuna130

6.5 Marcação intermediária no pretérito - Mamuna e Itamatatiua 133 
6.6 Marcação padrão de plural no verbo no pretérito - Mamuna e Itamatatiua . . . . . . . . . . . . . . . . . . . . . 136

6.7 Verbos sem marcação de plural no verbo no pretérito - Mamuna e Itamatatiua . . . . . . . . . . . . . . . . . . . 136

6.8 Marcação intermediária de plural no verbo no tempo presente - Mamuna e Itamatatiua . . . . . . . . . . . . . 138

6.9 Marcação padrão de plural no verbo no tempo presente Mamuna e Itamatatiua . . . . . . . . . . . . . . . . 139

6.10 Sem marca de plural em verbos no tempo presente - Mamuna e Itamatatiua . . . . . . . . . . . . . . . . . . . 140 


\section{Lista de Figuras}

2.1 Primeiros quilombos estudados . . . . . . . . . . . . . 9

3.1 Tráfico de escravos: regiões e portos . . . . . . . . . . . . . . 4 43

3.2 Línguas da África: troncos linguísticos. . . . . . . . . . . . . 51

4.1 Mapa político do Maranhão . . . . . . . . . . . . . . . . . . . 61

4.2 Localização de Alcântara (MA) . . . . . . . . . . . . . . 76

4.3 Mapa das Comunidades Remanescentes de Quilombos em Alcântara . . . . . . . . . . . . . . . . . 79

4.4 Área do Centro de Lançamento, Alcântara/MA . . . . . . . 80

4.5 Visão da entrada da comunidade de Itamatatiua, Alcântara/MA ...................... 82

4.6 Escola municipal, comunidade de Itamatatiua, Alcântara/MA 82

4.7 Peças de cerâmica produzidas na comunidade de Itamatatiua, Alcântara MA . . . . . . . . . . . . . . . 84

4.8 Peças de cerâmica produzidas na comunidade de Itamatatiua, Alcântara MA . . . . . . . . . . . . . . . . 84

4.9 Comunidade de Mamuna, Alcântara/MA . . . . . . . . . . . 86

4.10 Comunidade de Mamuna, Alcântara/MA . . . . . . . . . . . 87

4.11 Praia de Mamuna, Alcântara/MA . . . . . . . . . . . . 88

7.1 Tráfico de escravos: regiões e portos . . . . . . . . . . 158

1 Localização de Alcântara, Maranhão. . . . . . . . . . . . . . . 207

2 Território das Comunidades Remanescentes de Quilombos em Alcântara/MA. . . . . . . . . . . . . . . . . . . . . . 208

3 Área do Centro de Lançamento, Alcântara/MA . . . . . . . 209

4 Tráfico de escravos: regiões e portos. . . . . . . . . . . . . . . 210

5 Línguas da África: troncos linguísticos. . . . . . . . . . . . . 211

6 Tráfico de escravos: regiões e portos . . . . . . . . . . . . . 212 


\section{Capítulo 1}

\section{Introdução}

Nesta tese explorarei a marcação de terceira pessoa do plural, fenômeno que está no centro dos debates sobre a origem do português brasileiro, nas comunidades quilombolas de Mamuna e Itamatatiua, localizadas em Alcântara, no estado do Maranhão. De modo diferente dos estudos que analisam o mesmo tema e que dividem a análise entre a presença e a ausência de marcação de plural no verbos, irei analisar um terceiro tipo de marcação de terceira pessoa do plural, que emerge do processo fonológico de redução dos ditongos pós-tônicos finais ${ }^{1}$.

Esse terceiro tipo de marcação revela-se como o mais produtivo nas comunidades alcantarenses, não só em termos quantitativos, mas também por aparecer em contextos distintos aos de outras comunidades que apresentam esse tipo de marcação, como verbos no presente do indicativo, no pretérito imperfeito, verbos irregulares e de segunda conjugação.

Tais contextos, assim como a quantidade de ocorrências, mostraram a necessidade de olhar para essa redução de modo mais detido, pois indicava ser não apenas um fenômeno de redução fonológica. Ao que parece, esse morfema resultante da redução do ditongo nasal átono final estaria sendo entendido pelos falantes das comunidades alcantarenses como morfema marcador de terceira pessoa do plural.

Partindo do pressuposto de que as mudanças existentes no português do Brasil (PB) são fruto do contato com as línguas africanas (LAs) e indígenas no período colonial, esse tipo de marcação poderia ter resultado deste contato. Diferentes estudos apontam para a perda da nasalização final do verbo como consequência do contato com as línguas africanas (Lucchesi et al., 2009; Castro, 2001, entre outros) e relacionam a ocorrência do final

\footnotetext{
${ }^{1}$ Agradeço à banca por todas as cuidadosas sugestões. Os erros que, porventura, ainda estiverem presentes na tese são de minha inteira responsabilidade.
} 
verbal reduzido em vogal posterior à fala dos pretos (Mendonça, 1933; Raimundo, 1933, entre outros).

Diante disso e a partir de uma perspectiva teórica que leva o contato como fator chave para mudanças linguísticas, explorarei, ao longo da tese, como modo de entender a marcação intermediária de plural das comunidades de Alcântara, o contexto de formação dessas comunidades, a fim de traçar de que modo as línguas que estiveram em contato no período colonial moldaram as características existentes hoje nessas comunidades.

Para este intento, a tese está dividida como segue: no capítulo 2 serão apresentados os dados e a metodologia de tratamento desses dados, bem como os modelos de transcrição utilizados.

No capítulo 3 apresento a teoria que servirá de base para a análise dos dados (Mufwene, 2001, 2008), que considera tão importante quanto esses últimos a história da colonização e das relações socioeconômicas subjacentes às interações entre os membros da população que será estudada.

Essa teoria parte do princípio de que o contato entre diferentes línguas gera um banco de traços que entram em competição. Para o empreendimento da investigação linguística é preciso verificar os traços linguísticos em competição nesse ambiente, voltando-se para as propriedades gramaticais das línguas que participaram da formação do português brasileiro, no caso do presente estudo, analisando não só os traços das línguas participantes, mas também a possível congruência existente entre esses traços que pode ter levado a uma reestruturação da língua analisada.

Em resumo, para entender e analisar a formação do português brasileiro, deve-se iniciar com uma profunda investigação da história da colonização e das relações socioeconômicas subjacentes às interações entre a população da época e, concomitantemente, estudar as propriedades gramaticais das línguas em contato para delas extrair os possíveis traços em competição que podem ter integrado o banco formado.

O contexto histórico brasileiro no período colonial e os dados sobre a escravização dos africanos também serão trabalhados neste capítulo. Será possível perceber que, apesar da imprecisão das informações sobre as origens dos africanos vindos para o Brasil em condição de escravos, tanto em termos numéricos quanto em relação à origem exata deles, é possível traçar quais os principais lugares de onde esses africanos vieram: África Ocidental e Centro Ocidental, especialmente da região Angola-Congo. A partir dessa informação percebe-se que grande parte das línguas transplantadas para o Brasil era do tronco nigero-congolês, especialmente as línguas bantas (LBs); as línguas dos troncos afro-asiático e nilo-saariano vieram em menor número. Logo, as características relevantes para o entendimento da forma- 
ção do PB seriam as das línguas do primeiro tronco que, provavelmente, devem ter contribuído com a maior quantidade de traços.

Os estudos sobre a participação das línguas africanas na formação do português falado no Brasil são vários e serão explorados brevemente no capítulo 3. Têm início com os trabalhos de Jacques Raimundo e Renato Mendonça, em 1933, e abarcam diversas áreas da Linguística, como léxico, fonologia, morfologia e sintaxe. Serão apresentados alguns dos estudos dessas diversas áreas chamando a atenção para os estudos de Negrão \& Viotti $(2008,2010,2011,2012,2014)$, os quais apontam para um novo direcionamento nas pesquisas que buscam entender o português brasileiro a partir do contato com as línguas africanas.

No capítulo 4, ainda dentro da perspectiva de contato que leva em conta o contexto sócio-histórico de formação das comunidades estudadas, será apresentada a história de formação do Maranhão, dos quilombos maranhenses e de Alcântara. O Maranhão é o segundo estado em número de negros do país e foi o maior em número de população negra escravizada, fato que gera consequências para a população negra do estado ainda nos dias de hoje. $\mathrm{O}$ fato de a vida dos escravizados ter sido muito dura neste estado, tanto em relação aos maus-tratos dos senhores, como ao trabalho, além do descaso do governo, levou à insurreição da população escravizada, com a consequente fuga e formação de quilombos.

Além dos ambientes de revoltas, a grande área coberta de matas em torno das fazendas também facilitou a formação dos quilombos maranhenses, o que pode ser visto pela quantidade de comunidades remanescentes de quilombos que existem hoje no estado, em torno de 400.

O Maranhão é uma sociedade de escravização tardia, apresentando os traços de uma escravização agrícola desenvolvida apenas no último quarto do século XVIII, logo, esses quilombos foram formados em um momento posterior, se comparados a estados como a Bahia, por exemplo. Os quilombos se formaram em maior quantidade, no Maranhão, no decorrer do século XIX.

Especialmente em Alcântara, a autodeclaração dessas comunidades como remanescentes de quilombos veio tardiamente, principalmente após a implantação da Base de lançamento de Alcântara, que gerou conflitos territoriais. A questão da posse da terra também foi um fator importante para esse autorreconhecimento, embora a grande maioria ainda não possua a titulação da terra.

Interessante sempre observar que os quilombos de modo geral não permaneceram tão isolados em relação à sociedade, como é comum pensar; muito pelo contrário, estabeleciam comércio com a população livre, ven- 
diam produtos agrícolas, mantinham contato com os escravizados que não conseguiam fugir das fazendas e comunicavam-se entre si.

Durante toda a época de surgimento dos quilombos maranhenses, eles foram perseguidos pelas tropas que representavam o governo, ou pelos capitães do mato dos senhores das fazendas, ou ainda por pessoas livres que buscavam alguma recompensa. A fuga das fazendas não significava paz e liberdade, eles eram constantemente perseguidos, tendo que mudar de local e, muitas vezes, as pessoas que fugiam eram capturadas e levadas aos seus antigos donos.

Alcântara aparece, porém, com um cenário distinto, uma vez que grande parte dos quilombos foi formada a partir do abandono das terras pelos antigos donos e não pela fuga de negros escravizados.

A importância das comunidades quilombolas para o entendimento da formação do português brasileiro é inegável, como já apontava Mattos e Silva (2004). A organização dessas comunidades apresenta uma ecologia interessante para pesquisa linguística, uma vez que nelas conviveram diferentes "falares" em um ambiente relativamente isolado. $\mathrm{O}$ fato de ser um contexto no qual os aquilombados gozavam de certa liberdade, longe dos maus-tratos dos senhores das fazendas e das horas extenuantes de trabalho, possibilitava uma interação linguística mais ampla, tanto quantitativa como qualitativamente. Acredita-se, salvaguardadas as devidas proporções, que algumas dessas comunidades podem ainda preservar resquícios desse contato.

Partindo para as questões linguísticas, o capítulo 5 será dedicado a apresentar alguns dos trabalhos sobre a variação na concordância verbal em diferentes regiões do Brasil, a saber, Florianópolis (SC), São José do Rio Preto (SP), São Carlos (SP), Rio de Janeiro (RJ), Salvador (BA), Vitória da Conquista (BA), Feira de Santana (BA), Pelotas (RS), em comunidades do interior da Bahia, São Miguel dos Pretos (RS) e Caiana dos Crioulos (PB). E também no português europeu e nas variedades do português falado no continente africano, como o falado em São Tomé, em Luanda (Angola), em Cabo Verde e em Moçambique.

Os dados dos referidos trabalhos são analisados, em sua quase totalidade, pela perspectiva sociolinguista variacionista.

Embora os estudos sobre a concordância verbal e, de modo mais específico, a variação no uso da concordância verbal sejam muitos, com uma tradição de mais de trinta anos de análises e tentativas de relacionar a variação encontrada no português brasileiro à frequência de uso da $\mathrm{CV}$ em outras variedades do português, como o português europeu - em maior número - e o português falado na África, é possível observar que os estudos sobre essa variação em comunidades quilombolas são poucos. 
Nesse sentido, se considerarmos que esse fenômeno está no centro das discussões sobre as origens do português brasileiro e que as comunidades quilombolas seriam excelentes fontes de dados para investigar essa origem, seria de se esperar que estudos sobre tal fenômeno nessas comunidades fossem em maior número.

No capítulo 6, dedicado à descrição da marcação intermediária nas comunidades de Mamuna e Itamatatiua, será possível notar que os dados dessas comunidades divergem dos dados dos trabalhos apresentados no capítulo 5, logo, não seria possível empreender uma análise com os mesmos critérios. Enquanto os trabalhos apresentados no capítulo 5 tratavam da variação na $\mathrm{CV}$ no tocante à presença ou à ausência de marca de plural no verbo, tanto em uma tentativa de explicar o contato, quanto como uma tentativa de explicar a deriva, esta tese busca analisar os dados da marcação intermediária - termo amplamente explicado no decorrer do capítulo 6 tentando entendê-la a partir de uma teoria de contato que considera fatores sócio-históricos e econômicos como relevantes para a interação entre os indivíduos.

Serão apresentados os contextos de marcação intermediária no pretérito perfeito, no pretérito imperfeito e no presente do indicativo, esses dois últimos contextos distintos aos de outras comunidades que também apresentam a redução do ditongo nasal átono final em vogal posterior. Essas ocorrências serão relacionadas, além do tempo verbal, ao tipo de sujeito.

No capítulo 7, além da análise dessa marcação com verbos no presente do indicativo, verbos de segunda conjugação e verbos irregulares, será oferecida uma proposta de análise para a origem da ocorrência dessa terminação nas comunidades alcantarenses.

Os falantes das comunidades de Mamuna e Itamatatiua, por meio de

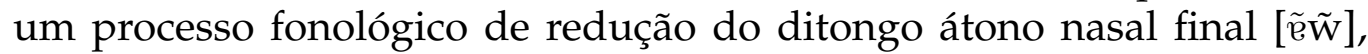
teriam reanalisado a terminação, transcrita ortograficamente como -0 , em um morfema de marcação de plural de terceira pessoa. Essa hipótese de reanálise seria reforçada pela ocorrência dessa mesma terminação verbal em contextos nos quais a redução fonológica para [v] não seria prevista, como verbos de segunda conjugação e verbos irregulares.

Tal redução fonológica teria sido resultado do contato com as línguas bantas no período de formação dessas comunidades e a posterior reinterpretação do morfema, um resultado da ecologia externa de formação.

O fato de este tipo de marcação — com final [-o] — ocorrer no português falado em Angola e em Moçambique ajuda a corroborar a hipótese apresentada, pois essas variedades de português ainda convivem com as LBs, faladas como línguas nativas pela grande maioria dos falantes, especialmente em Angola. 
Outro fenômeno explorado no mesmo capítulo é a ocorrência de verbos no plural com sujeitos singulares que também pode evidenciar um resquício do contato entre o português e as LBs a partir de outros traços dessas línguas. Embora esta marcação não represente a maioria das marcações do plural nem nas comunidades alcantarenses nem no português de Angola (PA), tampouco no português de Moçambique (PM), sua ocorrência é significativa, pois, ao considerarmos que o número verbal ocorre em todos os troncos das línguas africanas, especialmente no oeste daquele continente, é possível afirmar que as línguas que tiveram contato com o português quinhentista também apresentavam este fenômeno. E a presença de traços semelhantes nas variedades africanas do português pode ser um reflexo do contato deste português com as línguas nativas faladas tanto em Angola quanto em Moçambique.

O capítulo 8 será dedicado à ocorrência de verbos plurais com sujeitos coletivos singulares. Embora a ocorrência dessa marcação de plural com nomes coletivos não se relacione diretamente com a hipótese de reinterpretação do final verbal reduzido como morfema marcador de terceira pessoa do plural, apresenta uma característica que, teoricamente, não seria prevista para o português. De acordo com diferentes estudiosos do tema, verbos plurais com nomes coletivos singulares só poderiam ocorrer caso o sujeito estivesse distante do verbo; não é o que foi observado nos dados das comunidades alcantarenses apresentados na subseção 8.2, nem nos dados do PA e do PM.

No capítulo 9 apresento as considerações das análises dos dados, bem como da tese de modo geral. 


\section{Capítulo 2}

\section{Metodologia}

\subsection{Primeiros dados}

Os primeiros dados utilizados para a tese foram retirados do documentário Kilombos, realizado por Paulo Nuno Vicente e Luís Melo no ano de 2010, e das entrevistas com os mesmos informantes que participaram deste documentário. Tanto o documentário quanto as entrevistas estão disponíveis em http://www.kilombos.org/pt. O material foi transcrito ortograficamente, por mim, em LaTeX, com o editor de texto Kile.

As entrevistas foram feitas com 31 informantes de doze comunidades quilombolas localizadas no estado do Maranhão, a saber: Santo Antônio dos Sardinhas, São Sebastião dos Pretos, Santa Joana, Santa Rosa dos Pretos, Jacareí dos Pretos, Juçaral dos Pretos, Felipa, Monte Alegre, Matões dos Moreira, Monge Belo, Santa Maria dos Pinheiros e o povoado de Barreira Funda. E um informante do município de Itapecuru Mirim.

De acordo com informações encontradas no site do projeto, o documentário Kilombos não pode ser considerado um filme sobre a escravatura ou sobre o processo de luta pela titulação das propriedades. Filmado em várias comunidades maranhenses, "Kilombos procura ser o resgate de memórias e narrativas orais de uma cultura contemporânea, um contributo para uma antropologia visual de ideias, práticas e artefatos que são também o Brasil de hoje" e é uma iniciativa do projeto "O percurso dos Quilombos: de África para o Brasil e o regresso às origens" co-financiado pela Comissão Europeia e pela Cooperação Portuguesa, que terminou em julho de $2012^{1}$.

Segue abaixo a relação dos informantes com as siglas utilizadas para identificá-los:

\footnotetext{
${ }^{1}$ Para mais detalhes sobre o projeto, ver http://web. esecs.ipleiria.pt/quilombos/
} 
Primeiros dados

\begin{tabular}{|c|c|c|}
\hline Entrevistado & Nome do quilombo & Entrevista \\
\hline JWG & Quilombo Santo Antônio dos Sardinhas (SADS) & $02: 11$ \\
\hline $\mathrm{JR}$ & Quilombo Santo Antônio dos Sardinhas (SADS) & $02: 23$ \\
\hline GC & Quilombo São Sebastião dos Pretos (SSDP) & 03:34 \\
\hline JFC & Quilombo Santa Joana (STJN) & 02:11 \\
\hline JB & Quilombo Santa Joana (STJN) & $02: 46$ \\
\hline MAC & Quilombo Santa Joana (STJN) & $00: 51$ \\
\hline NS & Quilombo Santa Joana (STJN) & 01:57 \\
\hline TS & Quilombo Santa Joana (STJN) & $06: 55$ \\
\hline$\overline{\mathrm{LP}}$ & Quilombo Santa Rosa dos Pretos (SRDP) & 01:36 \\
\hline JP & Quilombo Santa Rosa dos Pretos (SRDP) & 01:39 \\
\hline JDV & Quilombo Jacareí dos Pretos (JRDP) & $00: 59$ \\
\hline JGT & Quilombo Jacareí dos Pretos (JRDP) & 09:07 \\
\hline JC & Quilombo Juçaral dos Pretos (JCDP) & 01:01 \\
\hline $\mathrm{AD}$ & Quilombo Juçaral dos Pretos (JCDP) & 04:39 \\
\hline 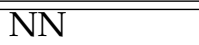 & Quilombo Felipa (QFLP) & 01:17 \\
\hline$\overline{\mathrm{JPL}}$ & Quilombo Monte Alegre (MTLG) & $02: 47$ \\
\hline VDA & Quilombo Monte Alegre (MTLG) & $08: 48$ \\
\hline RGC & Quilombo Monte Alegre (MTLG) & 03:18 \\
\hline EM & Quilombo Matões dos Moreira (MTDM) & $02: 28$ \\
\hline MG & Quilombo Matões dos Moreira (MTDM) & $02: 34$ \\
\hline$\overline{\mathrm{LDA}}$ & Quilombo Matões dos Moreiras (MTDM) & $\overline{\mathrm{DOC}}$ \\
\hline BLC & Quilombo Monte Alegre (MTLG) & DOC \\
\hline \multirow[t]{2}{*}{ LF } & Quilombo Santa Rosa dos Pretos (SRDP) & DOC \\
\hline & Transcrição do site & \\
\hline PS & Quilombo de Monge Belo (MGBL) & TS \\
\hline JBF & Quilombo Santa Rosa dos Pretos (SRDP) & TS \\
\hline ВРВ & Povoado de Barreira Funda (PVBF) & TS \\
\hline FB & Quilombo Santa Rosa dos Pretos (SRDP) & TS \\
\hline JS & Quilombo Santa Rosa dos Pretos (SRDP) & TS \\
\hline $\mathrm{SP}$ & Quilombo Santa Rosa dos Pretos (SRDP) & TS \\
\hline $\mathrm{CB}$ & Quilombo Santa Rosa dos Pretos (SRDP) & TS \\
\hline TN & Quilombo de Santa Maria dos Pinheiros (SMDP) & TS \\
\hline $\mathrm{AM}$ & Quilombo de Monge Belo (MGBL) & TS \\
\hline SG & Município de Itapecuru Mirim (ITMR) & TS \\
\hline $\mathrm{AF}$ & Quilombo de Monge Belo (MGBL) & TS \\
\hline
\end{tabular}




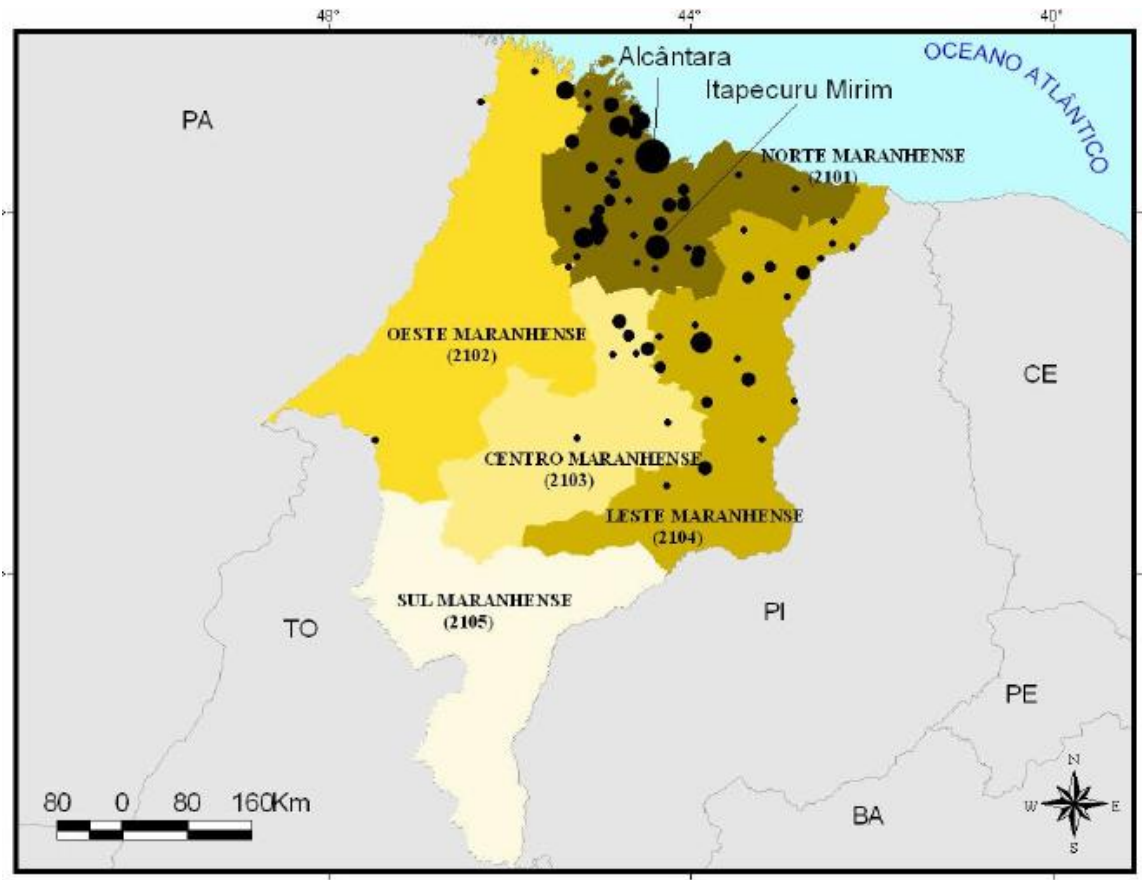

Figura 2.1: Distribuição dos primeiros quilombos estudados no estado do Maranhão. Fonte: www.kilombos.org

\subsubsection{Dos fenômenos inicialmente estudados}

Após a transcrição dos dados, fiz uma análise preliminar sobre quais fenômenos poderiam ser estudados nessas comunidades e, talvez pela experiência anterior do mestrado, acabei selecionando alguns fenômenos do sintagma nominal, a saber, a marcação de número e de gênero e o uso de algumas preposições.

Exponho brevemente a análise realizada sobre os dados iniciais da tese. Não apresentarei toda a análise, pois embora tenha continuado com o estudo da variação na marcação do plural, resolvi empreendê-lo no âmbito verbal, não mais no sintagma nominal. Os motivos para tal decisão serão explicados na seção sobre a viagem de campo — quando houve a mudança.

\subsubsection{Marcação de número}

Para o português brasileiro, sobre a marcação de plural dentro do sintagma nominal (SN), observam-se três possibilidades:

- a marcação em todos os elementos do SN, como em os meus tios queridos; 
- a marcação em apenas alguns elementos, como em os meus tio querido e todos aqueles estudante;

- e a marcação de plural em apenas um elemento do SN, em geral, na primeira posição, mas não necessariamente, como em os meu tio querido e todos aquele estudante .

No que concerne à variação de marcação do plural, diversos estudos observam que, quando ocorre a marcação de plural em apenas um elemento do SN, o primeiro seria aquele que, preferencialmente, receberia esta marca (Scherre, 1988, 1994, 2001; Guy, 1981; Oliveira et al., 2009; Baxter, 2009; Castro \& Pratas, 2006; Perini, 2011, entre outros) e levaria a noção de pluralidade para todo o SN.

Nos dados das comunidades quilombolas maranhenses também notase a variação na marcação de plural dentro do sintagma nominal. Nessas comunidades o plural pode ser marcado:

- em todos os elementos do sintagma nominal ${ }^{2}$, conforme exemplos (1) e (2):

(1) Então ...é ... ao longo DESSES ANOS — JR/SADS

(2) é isso que eu queria que NOSSOS GESTORES tivesse ... que olhasse esses meninozinho aí - JGT/JRDP

- apenas no primeiro elemento do sintagma nominal, sendo esse tipo de marcação o mais frequente (cf. (3) e (4)):

(3) E aí procurou que o papel tava ilegal ... que queria botar em ordem ... OS PAPEL ... né - TN/SMDP

(4) segundo OS DOCUMENTO que seu Nonato falou que tem JFC/STJN

- nos dois primeiros elementos do SN com o segundo elemento apresentando apagamento do "s", como em (5), (6) e (7):

(5) aqui nesse setor nossozinho aqui ... já ensinei UNS DOI ... pegava na mão deles botava em cima ... montava aqui pra trás ... pegava ... que é por aqui ó "pucutucu ... pucutucu ... pucutucu" JP/SRDP

\footnotetext{
${ }^{2} \mathrm{~A}$ marcação, em todos os elementos do sintagma nominal, ocorre de forma marginal nos dados das diferentes comunidades quilombolas estudadas.
} 
(6) pra num deixar morrer a identidade da DAS PRANTA MEDICINAI - NN/QFLP

(7) Ah ...pra mim é um grande prazer eu tá junto com meus ...com meus amigos ...com MEUS LUTADORE - TS/STJN

Para os dados em (6) e (7) a marcação não redundante do plural esperada seria das pranta medicinal e com meus lutador, respectivamente, sem a vogal no final.

Esse tipo de ocorrência também é encontrada no português de Angola, como em (8) e (9):

(8) outro bebê só tem dez mesi

(9) ante postuguesi irem embora

(Inverno, 2005: 133-4)

- apenas no segundo elemento do sintagma nominal, cf. (10). Esse tipo de marcação pode ocorrer tanto na posição de sujeito, como em (11) e (12), quanto na posição de objeto, em (13) e (14):

(10) Embora que A PESSOAS num ... né ... num sabe mesmo a ... o ritmo da toada ... né ... mas aquilo ali é uma adoração $\mathrm{LP} / \mathrm{SRDP}$

(11) ESSA HISTÓRIAS né ... que a gente é ... via no começo da da gente e hoje ... ela num tá desse jeito —LP/SRDP

(12) De uns tempo ... já O VELHOS morre ... morreu outro TN/SMDP

(13) Com certeza esperamos acontecer UM OUTROS MOMENTO porque é muito difícil falar de uma briga ... falar de um povo - EM/MTDM

(14) nós não devemos entregar o ... A NOSSAS ... as nossas herança que nossos avô deixou —JDV /JRDP

Sobre esse último tipo de marcação, Scherre (1988: 157) observa:

Com relação ao fato de os determinantes apresentarem menos marcas na primeira posição, é importante observar que neste caso os determinantes não marcados se encontram inseridos numa estrutura sintagmática peculiar, ou seja, ocorrem 
nas sequências do tipo [artigo ou demonstrativo + possessivo + substantivo] (casa do meus pais).

Ou seja, para esta autora, essa marcação ocorreria apenas em uma estrutura específica do tipo [artigo ou demonstrativo + possessivo + substantivo], todavia, nos dados do português escrito por africanos no século XIX, marcações deste tipo, ou seja, em que há marcação de plural apenas no segundo elemento do SN, não ocorrem somente nessa estrutura particular apontada por Scherre. Pelo contrário, nestes dados, as estruturas possíveis para esse tipo de marcação são bem diversificadas, conforme é possível observar a seguir nos dados retirados de Oliveira et al. (2009: 297):

- [ART + SUBST]: A Leis (MVS, 02, 19.02.1834), A Leis (MVS, 04, 05.04.1835);

- [ADJ + SUBST]: ACTUAL aDeministradores (JFO, 01, 18.10.1835), O Senhores (MSR, 13,06.06.1835);

- [INDEF + SUBST]: QUALQUER Mezários (LTG, 08, 02.02.1833);

- [SUBST + ADJ]: MEZA Mensaes (LTG, 08, 02.02.1833);

- [POSS + SUBST]: SEU mensaes (MSR, 15, 11.10.1835);

- $[$ ART + POSS + SUBST]: O seos trabalho (GMB, 02, 29.12.1834), A suas Somas (MSR, 15,11.10.1835);

- [ART + SUBST + ADJ]: O pogetos oferecidos (MC, 01, 21.10.1834), O socios Adiminstradores (MSR, 06, 07.01.1835);

- $[$ ART + ADJ + SUBST]: O novo Estatutos (MSR, 08, 08.02.1834), O dito Estatutos (MSR, 08,08.02.1834);

- [ART + ADV + SUBST]: O Mais Mezario (MVS, 02, 19.02.1834), O Mais Mezario (MVS[LTG,14, 04.10.1835]);

- [PREP + ART + SUBST]: DO termos (JFO, 04, 05.06.1836), DO Mencaes (MC, 02, 02.05.1841);

- [PREP + ADJ + SUBST]: PRUNANAMINE Vondades (MVS, 03, 29.03.1835);

- $\left[\mathrm{ART}+\mathrm{SUBST}+\mathbf{X}^{3}\right]$ : O numeros de cinco (MSR, 15, 11.10.1835);

\footnotetext{
${ }^{3}$ Sintagma preposicionado.
} 
- $[\mathrm{ART}+\mathrm{ADV}+\mathrm{SUBST}+\mathrm{ADJ}]:$ O Mais Mezario Dreminitador (MVS, $01,02.02 .1834)$;

- $[$ PREP + ART + SUBST + ADJ]: DA despozicoens Geral (JFO, 02, 01.11.1835), DO Senhores Devedores (MSR, 15, 11.10.1835);

- $[$ PREP + ART + POSS + SUBST]: DO Nossos estatutos (JFO, 02, 01.11.1835), DO nossos deveres (JFO, 08, 02.10.1836), DO Nossós Estatuto (JFO, 12, 02.10.1842);

- $[$ PREP + ART + NUM + SUBST]: Nossa Senhora do Ruzario DO 15 Misterio (MVS, 03, 29.03.1835);

- $[$ PREP + ART + NUM + SUBST + X]: PELA 8 ora da Menha (MC, 01, 21.10.1834), AO dois dia do Mez de Fevereiro (MVS, 01, 02.02.1834), AO deNove dia do Mez de Feverero (MVS, 02,19.02.1834), AO Cinco dia do Mez de Abril (MVS, 04, 05.04.1835), AO Cinco dia do Mez de Abril (MVS, 04, 05.04.1835);

- $[$ PREP + ART + ART + SUBST]: PELLA as fatas (MC, 02, 02.05.1841);

- $[$ PREP + ART + ADJ + SUBST]: DO Novos Adremenetador (MVS, $08,16.10 .1835)$.

Os dados das comunidades quilombolas do Maranhão também não estão presentes apenas nessa estrutura característica segundo Scherre [artigo ou demonstrativo + possessivo + substantivo], como se verá mais adiante.

Embora a marcação de plural apenas no segundo elemento do SN seja descartada, por questões quantitativas, de grande parte dos estudos sobre a variação de marcação do plural dentro do sintagma nominal, é possível observar que ela se encontra presente em diferentes estudos sobre variedades do português e línguas crioulas.

\section{Helvécia, Bahia}

(15) DO MEUS pai.

(Baxter, 2009: 281)

(16) A LEIS são feita.

(Antonino, 2007: 54)

São Tomé e Príncipe

(17) TODA ESSAS coesa.

(Baxter, 2009: 281) 


\section{Português de Almoxarife, São Tomé}

taqui ISSOS HOME

estão aqui esses homens.

(19) OUTRO TRABALHOS de televisão

outros trabalhos de televisão

(Figueiredo, 2008: 34)

\section{Caboverdiano}

(20) Ka ten OTRU MEIUS mas di vive

NEG ter outro meio mais PREP viver

Não tem outro meios de viver.

(21) $\mathrm{Bu}$ trabadja $\mathrm{ku}$ NHA POVUS

2SG trabalhar com POSS povos

Você trabalhou com meu povos.

(22) Ami NHA MININUS es fika tudu la pa fora 1SG.T POSS meninos 3PL ficar tudo lá PREP fora Meu meninos, eles ficaram todos lá fora.

(Baptista, 2002: 37,39)

\section{Português de Moçambique}

(23) A única coisa melhor era que houvesse assim ESSE MACHIMBOMBOS

(24) A Sida é UMA DOENÇAS transmitida

(25) A água é importante para os seres vivos pois assegura A SUA EXISTÊNCIAS

(26) Eu passei bem A FÉRIAS

(Dzeco, 2011: 28; 77 e 80)

A hipótese inicial para estes dados foi de que, em termos semânticos, o fato de a marcação de número atomizar o conjunto e, ainda, este traço ser interpretado apenas uma vez (Alexiadou et al., 2007), faria com que não houvesse necessidade de marcação redundante do plural, porém, a afirmação de que, no português brasileiro, o traço de número seria carregado no determinante (Magalhães, 2004; Silva et al., 2012, entre outros) seria questionada com base nos dados apresentados.

Para que o SN como um todo fosse considerado plural, bastaria então que essa informação fosse apresentada apenas uma única vez para o con- 
junto ser atomizado, independentemente se essa informação aparecesse no núcleo nominal ou no determinante.

\subsubsection{Marcação de gênero}

O gênero é uma das categorias gramaticais mais intrigantes, está presente em algumas línguas, porém é totalmente ausente em outras. A despeito de tal fato, o estudo dessa categoria é de grande importância e já foi realizado por vários estudiosos em diferentes línguas.

O gênero, entendido em um sentido amplo como modo de classificação dos nomes, é uma noção universal e, quanto à origem e aos critérios dessa classificação, existem várias hipóteses que não permitem uma interpretação unificada (Mattoso Camara Jr, 1973; Vilela, 1974, entre outros).

O português brasileiro possui dois gêneros, o masculino e o feminino. As gramáticas normativas, em geral, apontam que o primeiro é veiculado pelo morfema -o adicionado ao final do nome (menino) e o feminino pela adição do morfema - $a$ (menina). Essa relação, todavia, nem sempre é verdadeira. Embora algumas vezes, no PB, o gênero possa ser veiculado por meio da adição dos morfemas - - /- $a$ no final dos nomes, não é possível afirmar que o gênero seja veiculado apenas por aspectos formais, ou seja, não é possível tomar um critério puramente morfológico como ponto de partida para a classificação do gênero na língua: nomes como o planeta, $o$ mapa evidenciam que os morfemas não são suficientes para indicar gênero. Este independe da flexão do nome (Vilela, 1974; Carvalho, 1989; Mattoso Camara Jr, 1973; Mattoso Camara Jr., 2004, entre outros).

Outro problema encontrado em descrições tradicionais de gênero é o de não se realizar a distinção entre flexão de gênero e processos lexicais e sintáticos de indicação de sexo. É comum nas gramáticas, por exemplo, apresentar o nome mulher como feminino de homem, a descrição exata porém é que o substantivo mulher é sempre feminino, ao passo que outro substantivo, a ele semanticamente relacionado, é sempre de gênero masculino (Mattoso Camara Jr., 2004).

As associações de sexo feminino com gênero feminino e de gênero feminino com o marcador $-a$ são altamente favorecidas na subclasse de nomes que referem seres humanos. Estes três fatores, contudo, estão muito aquém de serem "sempre e somente" verdadeiros tanto na classe dos nomes com traço [+humano], quanto em qualquer outra classe.

Para Harris (1991), entre significado, forma e gênero, apenas gênero teria relevância direta, pois a associação tanto de significado/gênero quanto de forma/gênero impõem algumas restrições: 


\section{Masculino Feminino \\ * presidento presidente(a) \\ *linguisto linguista}

Nos exemplos acima, embora as palavras presidento e linguisto não existam nem em espanhol nem em português, elas não violam nenhuma restrição fonológica, no entanto, não são aplicáveis para se referir ao gênero masculino. Nesses casos, linguista pode indicar tanto o referente do sexo feminino quanto o referente do sexo masculino; em espanhol, presidente indica tanto o referente do sexo masculino quanto o referente do sexo feminino; já no português, temos a forma presidenta para indicar o referente do sexo feminino, embora, por questões outras, não seja unanimemente utilizada.

Essa relação entre gênero e sexo biológico também é questionada por diversos outros autores (Mattoso Camara Jr, 1973; Mattoso Camara Jr., 2004; Gleason Jr, 1978; Carvalho, 1989; Corbett, 1991; Barbosa, 1996; Monteiro, 2002; Bechara, 2007, entre outros). Para o PB, ela pode funcionar em alguns nomes com o traço [+animado], como o dono / a dona; o irmão / a irmã, mas não é sempre verdadeira como, por exemplo, em nomes do tipo o colega / a colega; o líder / a líder.

Mesmo nos seres animados, as formas do masculino ou do feminino podem não determinar a diversidade do sexo, o que ocorre nos substantivos chamados epicenos, por exemplo, cuja função semântica é a de apontar a espécie: a cobra, a lebre, a formiga, o tatu, o jacaré; nos substantivos aplicados a pessoas: o/a estudante, este/esta consorte que podem ser diferenciados pelo determinante; e também nos nomes denominados sobrecomuns, cuja referência a homem ou à mulher será depreendida pelo contexto: $o$ algoz, 0 carrasco, o cônjuge (Bechara, 2007).

Há, ainda, nomes com significados próximos, porém de gêneros distintos, como a ave / o pássaro e a criança / o menino. Estes pares podem indicar o mesmo referente, no entanto, possuem gêneros distintos, independentemente do sexo biológico do referente apontado. Alguns nomes, ainda, mudam de gênero no aumentativo ou no diminutivo, por exemplo um mulherão é o aumentativo de uma mulher.

Nomes com o traço [-animado] também comprovam que a relação gênero / sexo biológico / referente no mundo não pode ser feita pois mesmo esses nomes possuem gênero. Não há nada no objeto mesa, por exemplo, que o faça ser enquadrado na classe de gênero feminino, assim como não há nada no objeto lápis que o faça ser enquadrado na classe de gênero masculino, no português. Em suma, essa relação gênero / sexo biológico é vaga e pode não ser considerada tão relevante. 
Pode-se dizer então que o masculino e o feminino possuem uma relação do tipo gênero e espécie. Sob o aspecto do significado, enquanto o nome masculino tem uma aplicação genérica, o do feminino quase sempre tem um sentido específico. O masculino seria a classe dos nomes genéricos enquanto o feminino, a classe dos nomes específicos. No par fruto/fruta, o primeiro elemento é não marcado.

$\begin{array}{ll}\text { barco/barca } & \text { bolso/bolsa } \\ \text { braço/braça } & \text { caneco/caneca } \\ \text { cesto/cesta } & \text { cinto/cinta } \\ \text { barraco/barraca } & \text { horto/horta } \\ \text { lenho/lenha } & \text { manto/manta } \\ \text { ovo/ova } & \text { poço/poça } \\ \text { porto/porta } & \text { sapato/sapata } \\ \text { tamanco/tamanca } & \text { tampo/tampa }\end{array}$

Fonte: Monteiro (2002: 87)

Nesses casos o $a$ seria utilizado para marcar diferenças de dimensão entre o masculino e o feminino, do tipo secador / secadora.

Importante aqui é lembrar que essa divisão em classes genérica e específica funciona apenas para os nomes que possuem o par masculino/feminino, no entanto, no português brasileiro, há vários nomes que não possuem um par correspondente na outra classe.

É possível encontrar diversos pares semanticamente relacionados para os quais poderíamos estabelecer uma relação de proximidade:
o travesseiro/a almofada
o banco/a cadeira
o lápis/a caneta
o sofá/a poltrona
o edredon/a coberta
a calça / o short
o livro / a revista
o retrato/a foto
o freezer/a geladeira
o caixote/ a caixa
o e-mail/ a carta
o rodo/ a vassoura

O meu ponto aqui é que, em português brasileiro, essa relação masculino=genérico, ou não marcado, e feminino=específico deve ser vista com cuidado, já que temos diversos nomes que demonstram que essa relação não se sustenta todas as vezes.

Se formos tomar critérios de classificação mais específicos, podemos ter mais de uma classe masculino - com traço [+humano], com traço [humano] genérico, com traço [+animado] genérico, com traço [-animado] genérico etc. - , e mais de uma classe feminino - com traço [+humano], 
com traço [-humano] específico, com traço [+animado] genérico, com traço [-animado] genérico, com traço [+animado] específico, com traço [-animado] específico etc.

Em síntese, a divisão de gênero nas diversas línguas é antes um critério classificatório que agrupa os nomes em diferentes classes, do que uma aproximação dos diferentes gêneros ao sexo biológico ou qualquer traço do referente no mundo real.

Um exemplo a ser citado é o das línguas bantas, que possuem noções que não masculino e feminino para o critério de aplicação de gênero. Nessas línguas há um complexo sistema de classificação nominal no qual os nomes são agrupados em diferentes classes de acordo com valores morfológicos (singular e plural) ou semânticos (humano e não humano; animado e inanimado, entre outros).

Os nomes estão associados a uma determinada classe, e cada uma dessas classes possui um prefixo distinto que se agrupa aos pares, em oposição binária, indicando, quase sempre, o número: singular ou plural. Reproduzo a seguir um quadro com os prefixos de classe do quimbundo retirado de Gomes \& Okoudowa (2015: 141: adaptado):

\begin{tabular}{|l|l|l|}
\hline CLASSES & Valor & EXEMPLOS sg/pl \\
\hline \hline 1-2 mu / a & humano & mútù / átù (pessoa) \\
3-4 mu / mi & planta & mújî / míî̀ (árvore) \\
5-6 di / ma & corpo & dízwì / mázwì (língua) \\
7-8 ki / i & fabricado & kínù / ínù (pilão) \\
9-10 Ø; i / 3 & animal & hómbò / 3ìhómbò (cabra) \\
11-6 lu / ma & objeto & lúmbù / màlúmbù (muro) \\
12-13 ka / tu & diminutivo & kátótè (manchinha) \\
14-6 u / ma & abstração & ùkámbà / mákámbà (amizade) \\
$15-6 \mathrm{ku} \mathrm{/} \mathrm{ma}$ & infinitivo & kújà / mákújà (ir) \\
$16 \mathrm{bu}$ & em cima de & búlú (no céu) \\
$17 \mathrm{ku}$ & junto a & kúkù (por aqui) \\
$18 \mathrm{mu}$ & dentro de & mùbátà (na casa) \\
\hline
\end{tabular}

Todas as raízes nominais do quimbundo são precedidas por um dos 18 prefixos de classe que desencadeiam o mecanismo de concordância, o qual possui um papel importante em separar as classes nominais nas línguas bantas, em geral. Cada agrupamento de classe corresponde a um gênero. Nesse sentido, de acordo com o quadro apresentando as classes nominais do quimbundo, esta língua teria 12 gêneros e 18 classes nominais.

Em lembama, falada do Gabão, por exemplo, há 12 classes nominais e 9 gêneros (Gomes \& Okoudowa, 2015: 142: adaptado): 


\begin{tabular}{|l|l|l|}
\hline GENNERO & CLASSES & VALOR \\
\hline \hline I & Classes 1 e 2 & deuses, humanos, animais e fen. da natureza \\
II & Classes 3 e 4 & plantas, animais, objetos e partes do corpo \\
III & Classes 5 e 6 & partes do corpo \\
IV & Classes 7 e 8 & lugares, líquidos, objetos e animais \\
V & Classe 9 & partes do corpo, plantas, animais e objetos \\
VI & Classe 10 & partes do corpo, plantas, animais, objetos \\
VII & Classes 7 e 4 & \\
VIII & Classe 11 & substantivos abstratos \\
IX & Classe 12 & infinitivos, objetos, adjetivos e substantivados \\
\hline
\end{tabular}

Heine (1982) em Katamba (2003) observa que há, aparentemente, dois princípios básicos para atribuir um certo nome a um determinado gênero. O gênero pode ser atribuído com base em um critério semântico como sexo, por exemplo, em que nomes masculinos referem a machos e nomes femininos referem a fêmeas. Alternativamente, nomes podem ser alocados em determinados gêneros de uma maneira mecânica, semanticamente arbitrária.

Conforme foi possível verificar em línguas como português e espanhol, por exemplo, a atribuição arbitrária de um gênero não é algo incomum às línguas. O importante aqui é o fato de que nem sempre a ideia de gênero está associada a noção de sexo biológico do referente, levando em conta, inclusive, que muitos referentes não possuem tal noção.

De modo mais simples, o gênero é inerente ao nome, contudo, não há nada na forma, nem no significado, que indique que o nome seja masculino ou feminino, ou seja, o gênero independe da forma ou da morfologia do nome, o que vai indicar o gênero daquele nome são os demais elementos do sintagma nominal. O gênero do nome se 'espalharia' para o determinante e para o adjetivo e estes evidenciariam o gênero daquele nome, dado que nem o determinante, nem o adjetivo possuem gênero inerente, mas sim concordam com o nome ao qual estão relacionados. E é nesse sentido que é possível afirmar que o gênero é uma propriedade do sintagma nominal.

Dentro dessa perspectiva, sempre em uma situação de conflito, o gênero seria aquele atribuído ao determinante e ao adjetivo. Por exemplo, em $o$ pele-vermelha pacificado a forma do determinante $o$ e do adjetivo pacificado manifestam o gênero masculino do sintagma nominal todo. Esse gênero manifesto pelo determinante e pelo adjetivo bloquearia o gênero feminino de pele indicado pelo adjetivo vermelha. Ou seja, em qualquer circunstância o gênero do sintagma nominal do nome equivaleria àquele indicado claramente no determinante e no adjetivo (Carvalho, 1989). 
Ainda que seja possível levar essa hipótese adiante, não se pode esquecer que, no português, há casos em que nem sempre ocorre uma concordância, mesmo entre o determinante e o adjetivo de um mesmo sintagma nominal. Carvalho (1989) apresenta um exemplo que, embora possa não parecer válido nos dias de hoje, ou pelo menos a minha intuição não o considera válido, ajuda a compreender os casos de variação existentes em comunidades afrodescendentes, por exemplo. $\mathrm{O}$ autor advoga a existência de dois níveis de gênero dentro do sintagma nominal: o do SN enquanto tal e o do nome que o integra:

A modelo brasileiro

O nome modelo é dotado de gênero próprio inerente masculino, que se associa ao valor substantivo desse nome e controla o gênero de brasileiro, levando-o a assumir por concordância a forma masculina. O determinante, por sua vez, assume claramente a forma feminina $a$, em aparente discordância com o nome e com o adjetivo. O sintagma em causa, de acordo com a análise, é perfeitamente aceitável gramaticalmente, admite-se nele a existência de dois níveis de gênero próprio:

i. a do gênero inerente masculino do nome modelo, que está impondo concordância ao adjetivo brasileiro. O valor substantivo a que se vincula esse gênero transparece através do significado "substantivo" peculiar de modelo (padrão ou manequim).

ii. a do gênero feminino do sintagma nominal a modelo brasileiro, que exige a forma feminina do artigo. $\mathrm{O}$ valor substantivo a que se vincula o SN evidencia-se através do próprio significado do conjunto: enquanto modelo (no gênero masculino) por si é inespecificado, podendo significar padrão ou manequim, o SN inteiro (no gênero feminino) refere-se especificamente a "uma mulher brasileira que exerce a função de manequim".

Partindo desse exemplo, é possível dizer então que, mesmo dentro da concordância, haveria uma hierarquia na veiculação do gênero, tendo o determinante maior proeminência na marcação de gênero do que o adjetivo. Nesse sentido, os casos de variação não seriam um problema, permanecendo o gênero designado pelo determinante. Resumindo, no português brasileiro, o gênero seria indicado através do processo de concordância e da correlação anafórica (Said Ali, 1964: 33; Lucchesi, 2009a: 298, entre outros).

- A variação de gênero: 
A variação de concordância em relação ao gênero pode ser encontrada em comunidades afrodescendentes e nas variedades do português falado na África. Em Helvécia, na Bahia, o nível de variação é bastante reduzido, em torno de 5\% (Baxter, 1992; Lucchesi, 2000, 2009a) e pode ser exemplificado da seguinte forma (Lucchesi, 2009a:306):

1. Valor positivo - realização da concordância de gênero no SN

(28) Eu comprei ESSA CASA aí NA RUA.

(29) Fiquei no soro durante A NOITE TODA.

2. Valor negativo — não realiza a concordância de gênero no SN

(30) Ele era UMA PESSOA MUITO QUERIDO.

(31) foi vendeno TUDO ESSAS MADEIRA.

(32) se tirá O CERTIDÃO DE ÓBITO do meu pai.

A variação presente na comunidade de Helvécia é explicada por meio de um processo histórico de contato de línguas. Quando da formação de Helvécia em meados do século XIX e princípio do século XX, houve, nas palavras de Lucchesi, a aquisição precária do português por parte dos africanos e uma consequente redução na marcação de gênero. Esse modelo, por conseguinte, teria sido nativizado entre os descendentes desses africanos. Posteriormente, à medida que os membros dessa comunidade aumentavam sua relação com o mundo exterior, o uso da regra de gênero teria sido gradativamente implementado.

O pequeno índice de variação em Helvécia, apenas 5\%, indicaria, segundo o estudo, um processo de mudança em curso, na medida em que se observa um padrão ascendente de aplicação da regra de concordância. A marcação de gênero seria feita, essencialmente, no núcleo nominal.

A marcação de gênero também se apresenta como um fenômeno variável no português falado em Angola:

(33) PRIMEIRA FILHO já tem trinta e oito ano.

(34) eu tinha MINHAS IRMÃOS.

(35) fui lá embaixo NA MINHA MANO no centro.

(Inverno, 2005: 136) 
Nessa língua a variação seria tão grande que, em alguns casos, nas palavras de Inverno, tornaria difícil perceber se o falante refere-se a uma entidade masculina ou feminina (Inverno, 2005: 137):

agora A SENHORA FICOU SOZINHO! Depois a sinhora começa a dizer: "Eu tinha mesmo MINHAS IRMÃOS e tinha TODO FAMÍLIA. só NETA já tem bué de NETA. É mãe DO vinte cinco NETO! antão, tinha UM AVÔ, O MEU AVÔ, avô de pai, que na[s]ceu pai. Po[i]si. ESSA AVÔ dizia assim (... ) não cumpri daquilo qu'a velha, o avô, dizia.

Destaco aqui, no tocante à afirmação de que não é possível saber se o nome refere-se à entidade masculina ou feminina, que a questão do gênero do nome não tem a ver com isso. É claro que quando se trata de nomes com traço [+humano] espera-se que a relação seja unívoca, nomes femininos refiram-se a entidades do sexo feminino e nomes masculinos refiram-se a entidades do sexo masculino. É importante lembrar que essa relação não é sempre verdadeira e nem necessária e que se deve manter as noções gênero do nome e sexo biológico bem distintas.

No português falado em Moçambique é igualmente possível evidenciar a variação na marcação de gênero:

(39) Eu tenho MINHAS NETOS.

(40) É UMA CIDADE mais ou menos IDÊNTICO à de Maputo

(41) AS CONDIÇÕES não estão nada BOM.

(Gonçalves, 2015: 12)

Tanto no português falado em Angola, quanto no português falado em Moçambique, a variação na atribuição de gênero seria tão elevada que poderia ser considerada imprevisível e arbitrária (Petter, 2008: 126). Gostaria de lembrar que mesmo nas línguas em que não há uma acentuada variação de gênero, este, além de não ser previsível, é arbitrário, logo, isso não seria uma consequência da variação.

No Brasil, além de Helvécia, a variação na marcação de gênero é encontrada também no Cafundó (Petter; Petter, 1999), e em Cangume (Petter \& Zanoni, 2005). A variação de concordância, porém, gira em torno de 5\%, o que revelaria, de acordo com os autores, uma mudança quase completa em favor da adoção da norma padrão.

Nas comunidades quilombolas maranhenses há, igualmente, uma variação na marcação de gênero. 
(42) Como eles num tinha documento ... num tinha recurso ... né ... AS PESSOAS PODEROSOS começaro a dilapidar o patrimônio — JFC/ STJN

(43) Porque logo são UMAS PESSOA ESTUDADO — NS/STJN

(44) Quando a criança tá de pé só no pegar ... no reparar ... A PARTEIRA JÁ É ACOSTUMADO — TS/STJN

Os dados em (42), (43) e (44) seguem a hipótese da concordância, os determinantes as, umas e $a$ evidenciam o gênero dos nomes pessoas, pessoa e partera, respectivamente. $\mathrm{O}$ fato de o adjetivo não exibir a concordância não interfere no fato de o gênero do SN ser feminino, uma vez que ele já foi evidenciado pelo determinante e não há a obrigatoriedade de ser marcado no adjetivo.

(45) Porque os serviços que eles querem ... O SÃO LUÍ́s não ... não ...não ... é mais certo — SP/SRDP

Aqui, em (45), há a concordância com o nome São Luís, que é masculino. A marcação de gênero esperada, que é a mais amplamente utilizada, seria $a$ São Luís, concordando com a ideia de cidade, no entanto, optou-se por uma concordância com o gênero do nome, ou melhor, gramatical, o que, apesar de poder causar um primeiro estranhamento, é perfeitamente aceitável.

(46) “Em dezembo não ... tu vai ganhar agora em novembo ... no fim de novembo e TEU MENINO É MULHER" — TS/ STJN

No dado em (46), o gênero do SN é masculino, no entanto, o referente possui o sexo biológico feminino, indicado pelo nome mulher, o que evidencia que a relação gênero do nome e sexo biológico do referente não é sempre necessária. Essa estratégia é bem parecida com a do caboverdiano para nomes com o traço [+animado], em que o sexo biológico do referente é apontado pelos nomes matxu ou femia, estratégia distinta da atribuição de gênero do sintagma nominal que, em boa parte dos casos, permanece no masculino.

(47) Que ESTE FOI UMA HERANÇA que nossos avós ... meu bisavô deixou que foi o senhor de meu avô —JDV/JRDP

À semelhança do exemplo (46), em (47) o gênero é indicado ao final do SN e o determinante anterior ao verbo não exibe a concordância. Note-se que os exemplos possuem estrutura predicativa, com verbo de ligação e, nos 
dois casos, a indicação de gênero se dá após o verbo, os determinantes e os nomes que antecedem o verbo de ligação permanecem no masculino.

Sobre esses dados, pode-se dizer que, embora os dados (42), (43) e (44) apresentem variação na marcação do gênero, esta não comprometeria as teorias que advogam ser, o gênero, evidenciado através da concordância, uma vez que os determinantes apresentam concordância com o gênero do nome, independentemente do adjetivo. Para o dado (45), também não há qualquer problema quanto a essa marcação, a concordância escolhida dá-se no nível formal e não semântico.

Já em (46) e em (47), o questionamento que surge é se a estrutura predicativa interfere na manifestação do gênero, ou seja, se o verbo bloqueia a concordância dos elementos que estão antepostos a ele, deixando apenas os elementos mais próximos ao nome receberem essa concordância.

Diante desses dados e análises iniciais, ainda permaneceu o questionamento sobre as estruturas predicativas, além da frequência dessa variação, se é equivalente aos demais estudos de comunidades afrodescendentes brasileiras (5\%), além da frequência de variação da marcação com nomes de traço [+ animado/+ humano].

\subsection{Trabalho de campo}

O trabalho de campo foi realizado entre os dias 04 e 26 de julho de 2016. É fato que realizar um trabalho de campo é sempre um desafio para qualquer pesquisador. Na grande maioria das vezes, não sai como planejado e meu trabalho de campo no Maranhão não foi diferente.

$\mathrm{O}$ intuito era visitar as comunidades nos municípios de Bacabal e Itapecuru-Mirim, das quais já havia feito uma análise prévia dos dados, para realizar testes semânticos e sanar as dúvidas que surgiram nas análises iniciais do corpus, apontadas na seção anterior. O plano inicial era permanecer dez dias em cada município para visitar as comunidades e realizar os testes necessários.

Alguns contatos prévios já tinham sido estabelecidos via internet, pois algo que aprendi em meu trabalho de campo em Cabo Verde, na África, foi que não se pode chegar no informante, ou na comunidade na qual se quer realizar a pesquisa, diretamente, pois dificilmente você conseguirá realizar suas entrevistas ou testes a contento. Você não será bem recebido ou, ainda, os informantes podem querer te cobrar pela entrevista, ou falarão qualquer coisa para "te despachar". A melhor abordagem é através de um intermediário, alguém de confiança do informante ou daquela comunidade que te apresente como pesquisador, que fale de você e de sua pesquisa para 
que os informantes confiem em você tanto como pesquisador quanto como pessoa. Caso não consiga esse intermediário, é melhor seguir em frente, no entanto, eu precisava encontrar estes contatos para que pudesse ir às comunidades ${ }^{4}$.

Nos primeiros dias de trabalho fiquei em busca desses contatos. Primeiro em São Luís, com a Associação das Comunidades Negras Rurais (ACONERUQ), no entanto, não obtive sucesso. Os números de telefone não existiam, os endereços eram desencontrados e as pessoas não conseguiam informar nada a respeito. Acabei por descobrir, em meu último dia de campo, que essa associação já não estava mais ativa.

Diante dessa adversidade, visitei a cidade de Alcântara, que não estava no roteiro, porém, é uma cidade próxima a São Luís, com alguns quilombos. O primeiro contato foi excelente e deixei essa cidade como uma opção viável caso as que tinha como meta não dessem certo.

Na primeira cidade do interior, Bacabal, não obtive sucesso. Infelizmente, o contato estabelecido para me levar às comunidades não compareceu à reunião marcada na UFMA (Universidade Federal do Maranhão) e, como eu já estava na cidade há três dias esperando este contato e a questão da violência estava presente, decidi seguir adiante.

Fui para a cidade seguinte do roteiro, Itapecuru-Mirim. Não foi muito fácil estabelecer os primeiros contatos nessa cidade. A Casa de Cultura, referência que eu tinha, estava desativada e, depois de conversar com algumas pessoas, fui até o sindicato dos professores da cidade e entrei em contato com Jorge Silva dos Santos, presidente do sindicato, que me colocou em contato com Rildo Pinto da comunidade Felipa. Rildo me acompanhou até essa comunidade e as de Moreiras e Santa Rosa do Barão (ou Santa Rosa dos Pretos). Embora muito solícitos, não foi possível a aplicação dos testes, devido ao tempo escasso das pessoas que estavam me acompanhando e da impossibilidade de eu permanecer nessas comunidades, então fiz apenas o reconhecimento, conversei com algumas pessoas, gravei algumas entrevistas e segui adiante ${ }^{5}$.

\footnotetext{
${ }^{4}$ Uma constante em todo o estado foi a questão da segurança. Fui muito avisada em São Luís e em Bacabal, cidade do interior, em relação a isso. Sabemos que quando se viaja sozinho fica-se mais vulnerável e suscetível a essas coisas e, infelizmente, quando se é mulher, fica-se mais exposta ainda. Então, tive de tomar cuidado redobrado para não me expor, nem me colocar em situação de risco. O que, querendo ou não, acaba limitando um pouco as coisas.

${ }^{5}$ Outra lição que aprendi em Cabo Verde e trabalhando com pessoas é que não dá para chegar aplicando testes diretamente, a menos que você já tenha estabelecido uma relação anterior com essa comunidade. Deve haver um reconhecimento do local, as pessoas sentem muita necessidade de contar as histórias do lugar, de mostrar as coisas, o que leva tempo. E esse primeiro contato é fundamental para seguir com a aplicação dos testes, $\mathrm{o}$
} 
Por fim, já no final da segunda semana, acabei seguindo para a cidade que havia "reservado", Alcântara, na qual programei mais de uma semana de campo, esperando que fosse possível realizar os testes e uma abordagem mais independente.

Nessa cidade tive a felicidade de encontrar Sérvulo de Jesus Morais Borges, o Borjão, grande conhecedor da causa quilombola em Alcântara, com mais de trinta anos de trabalho em prol das comunidades e em especial da luta dessas comunidades com a Base Espacial da Aeronáutica. Borges não apenas me ofereceu estadia, como também me colocou nas comunidades quilombolas de Itamatatiua e Mamuna, nas quais pude permanecer por dois dias, em cada, e realizar gravações com os moradores dessas comunidades.

$\mathrm{O}$ acesso às comunidades é relativamente fácil. Itamatatiua está localizada a uma hora de carro da sede de Alcântara, o acesso pode ser feito por ônibus - apenas dois por dia - ou por moto-táxi e a rodovia de acesso, MA-106, está em ótimas condições. Para Mamuna não há ônibus direto; localizada no litoral, o acesso pode ser feito por carro ou moto-táxi. Para essa comunidade consegui, por intermédio de um amigo, carona com o ônibus escolar que transportava as crianças da comunidade para a Colônia de Férias, uma atividade da prefeitura que ocorre durante as férias escolares e tem por objetivo entreter as crianças das diferentes comunidades de Alcântara.

Diante dos imprevistos ocorridos durante o campo, não podia simplesmente aplicar os testes que havia levado nas comunidades de Alcântara, pois não sabia se iria encontrar os mesmos fenômenos das comunidades de Bacabal e Itapecuru-Mirim, ainda mais considerando a localização desses municípios, já que Alcântara é mais próxima à capital.

A decisão que tomei então foi recomeçar, gravar novamente entrevistas espontâneas com os falantes das comunidades, para daí realizar as transcrições e verificar quais fenômenos poderiam ser estudados. Embora tenha sido uma decisão arriscada, não havia outro meio de proceder considerando o tempo que restava de campo e de tese.

Semelhante ao relato de Almeida (2006b) sobre seu trabalho de campo nas comunidades de Alcântara, no qual pude identificar muitos pontos comuns com o meu, tão logo chegava nas comunidades e esclarecia o objetivo da minha estada bem como o da pesquisa, os moradores, sistematicamente, sugeriam conversar com os que detinham a autoridade de constituir a história do lugar, em geral os mais velhos - mais evidente em Itamatatiua -, os

que demanda, no mínimo, duas visitas à mesma comunidade. Logo, nas comunidades de Itapecuru essa segunda etapa não foi possível. 
dirigentes das comunidades e os que tinham algum papel na organização delas, ou seja, dez anos após o trabalho de campo realizado por Alfredo Wagner, as atitudes quanto a esta questão não apresentaram mudanças.

Entre uma entrevista e outra, procurava sempre entrevistar algum morador que não tinha sido indicado e que demonstrava uma abertura para conversa. Sobre o fato de as pessoas indicarem, invariavelmente, os idosos para a realização das entrevistas, Almeida (2006b: 29) observa:

É bem verdade que os idosos, que usufruem de aposentadorias, atualmente são vistos num patamar superior de possibilidades econômicas, com papel de destaque, seja na manutenção de seus grupos familiares, devido aos recebimentos mensais regulares, seja no âmbito da própria entidade sindical dos trabalhadores rurais, em virtude de suas contribuições sindicais voluntárias. Embora não tenham qualquer obrigatoriedade legal em recolhê-las, cerca de 900 aposentados têm contribuído generosa e espontaneamente para o STTR de Alcântara. Trata-se de um número significativo, uma vez que, conforme os dados do Censo Demográfico de 2000 do IBGE, a população residente do município de Alcântara corresponde a 21.291 habitantes, sendo que $73,3 \%$ encontram-se na área rural distribuídos por mais de duas centenas e meia de povoados, e os que se encontram numa faixa etária igual ou superior a 60 anos correspondem a 1.833 habitantes, ou seja, pouco mais de 8,0\% da população residente.

Por outro lado, a abordagem dos informantes mais novos foi dificultada, em geral, pelo fato de a grande maioria não participar ativamente das atividades das comunidades, seja das atividades que geram algum retorno financeiro, como a roça, a cerâmica ou a pesca, seja das atividades culturais dessas comunidades. Nos relatos dos informantes, observa-se uma grande preocupação em relação à parcela mais jovem da população desses povoados devido ao desinteresse em continuar as atividades tradicionais, ou em ter uma atividade remunerada regular. O que se nota é que uma boa parte dos jovens acaba vivendo da renda dos mais velhos, tanto dessas atividades tradicionais quanto da aposentadoria.

Em verdade, os que movimentam a economia dessas comunidades em Alcântara são os idosos, pelas atividades que geram alguma renda e principalmente pela aposentadoria.

As entrevistas foram realizadas de modo espontâneo, pelo motivo já explicitado acima, os temas abordados foram aqueles familiares à comunidade. No caso de Itamatatiua, uma comunidade cuja renda é basicamente 
da venda de cerâmica, um dos tópicos das entrevistas era sobre a cerâmica, o surgimento, a importância para a comunidade, o modo de fabricação, além de temas como o dia a dia na comunidade, emprego, mudança da comunidade no decorrer dos anos, e algumas percepções dos informantes sobre temas pertinentes que surgiam no decorrer das entrevistas.

Em Mamuna, além de temas como o dia a dia na comunidade, emprego, mudança da comunidade no decorrer dos anos, o tópico comum foi a luta da comunidade com a Base de Lançamento de Alcântara e a constante ameaça de desapropriação da comunidade, assim como aconteceu com comunidades que eram próximas à Mamuna e foram deslocadas.

A possibilidade de tópicos em uma entrevista espontânea é gigantesca, contudo, temas pertinentes ao cotidiano dos entrevistados facilitam o desenvolvimento do tema por parte dos informantes e os deixam mais à vontade, algo essencial para a coleta dos dados. As gravações das entrevistas duraram em média 40 minutos, mas, no geral, as entrevistas começavam antes de o gravador ser ligado e terminavam bem depois de o gravador ser desligado.

\subsection{Transcrição}

Tão logo retornei da viagem de campo iniciei as transcrições dos dados, que foram realizadas em um programa específico para transcrição linguística, ELAN.

O ELAN é um programa de anotação de arquivos de áudio e vídeo, desenvolvido pelo Instituto Max Planck de Psicolinguística em Nijmegen, Holanda, e está disponível para download no site https://tla.mpi.nl/ tools/tla-tools/elan/ ${ }^{6}$.

No mesmo site é possível encontrar um manual para a utilização do ELAN, em inglês. Utilizei o manual feito pela professora $\operatorname{Dr}^{a}$ Livia Oushiro para o Projeto SP2010: construção de uma amostra da fala paulistana, disponível no site do projeto, http://projetosp2010.fflch.usp.br/, por ser mais sucinto.

Para o tratamento dos dados, optei por seguir algumas normas de transcrição do manual de Oushiro, como, por exemplo, marcar trechos ininteligíveis com (xxx), pausas curtas com ..., trechos duvidosos entre parênteses e truncamentos marcados com (/).

\footnotetext{
${ }^{6}$ No site é possível encontrar as versões compatíveis com os sistemas operacionais Windows, Mac OS ou Linux. No meu caso, embora utilize o Linux para o desenvolvimento da tese, para o ELAN usei a versão para Windows.
} 
Importante ressaltar que se trata de uma transcrição ortográfica ${ }^{7}, \operatorname{logo}$, optei por não alterar a ortografia das palavras, exceto para o fenômeno em questão - concordância verbal -, ou para algum fenômeno que não fosse considerado geral no português brasileiro, como, por exemplo, a alteração da vogal em $a$ pela $e$ em compremo, que é atestada apenas em certas comunidades.

Por mais que algumas transcrições de comunidades quilombolas reproduzam palavras do tipo andar, comer, pedir como andá, comê, pedí, não acho por bem transcrever as palavras dessa forma, considerando que a apócope do $r$ no infinitivo é um fenômeno amplo que atinge a norma popular e culta, de norte a sul do país e já foi atestada por diferentes autores (Marroquim, 1934; Elia, 1987; Amaral, 1920, entre outros).

Outro fenômeno que não registrei nas transcrições foi a monotongação, do tipo chegou, falou, dinheiro, pinheiro, transcritas muitas vezes como chegô, falô, dinhêro, pinhêro, pois, assim como a apócope, o apagamento de semivogais em ditongos nos nomes é amplo no português brasileiro e não restrita a essas comunidades.

Contudo, conforme já apontado, a variação da concordância verbal foi registrada nas transcrições por ser o fenômeno analisado e, ainda, por apresentar particularidades que não são encontradas no português brasileiro falado fora dessas comunidades, como ficará claro no decorrer da tese.

Em Itamatatiua foram entrevistados dez informantes entre a faixa etária de 21 a 86 anos. Apenas uma informante possuía o ensino médio completo, quatro informantes eram analfabetos, cincos tinham cursado até a quarta série do ensino fundamental e um informante havia concluído o ensino fundamental. Todos eles tinham nascido e passado toda a vida na comunidade.

Na comunidade de Mamuna, entrevistei oito informantes entre a faixa etária de 31 a 86 anos. Três informantes eram analfabetos, um informante cursou até a quarta série do ensino fundamental, um informante cursou até a quinta série do ensino fundamental, dois informantes concluíram o ensino fundamental e uma informante possuía o ensino superior completo. Dos oito informantes, dois deles passaram um tempo fora da comunidade, os demais tinham nascido e passado toda a vida na comunidade.

A falta de engajamento dos jovens nas duas comunidades impediu a realização de entrevistas com informantes de faixa etária mais jovem.

\footnotetext{
${ }^{7}$ Conforme apontado pela banca, a transcrição fonética poderia auxiliar no entendimento do fenômeno em questão, especialmente quando a forma de terceira pessoa do plural no tempo presente se confunde com a forma da primeira pessoa do singular, no entanto, ela não será contemplada na presente tese e sim explorada em trabalhos futuros.
} 
Todas as informações que pudessem identificar o informante foram abreviadas, como o nome do próprio informante e alguns nomes citados. A seguir apresento um quadro com os dados sobre os informantes:

\begin{tabular}{|c|l|c|}
\hline Informante & Comunidade & Entrevista \\
\hline \hline MJJ & Itamatatiua (ITM) & $32: 06$ \\
TV e ENJ & Itamatatiua (ITM) & $20: 32$ \\
ENJ & Itamatatiua (ITM) & $41: 27$ \\
JB e CL & Itamatatiua (ITM) & $34: 32$ \\
MJL e RJ & Itamatatiua (ITM) & $47: 17$ \\
DJ & Itamatatiua (ITM) & $16: 05$ \\
NJ & Itamatatiua (ITM) & $42: 56$ \\
ACJ & Itamatatiua (ITM) & $28: 41$ \\
\hline \hline MGS & Mamuna (MMN) & $45: 52$ \\
CD & Mamuna (MMN) & $50: 51$ \\
IPM & Mamuna (MMN) & $25: 01$ \\
MFF & Mamuna (MMN) & $31: 38$ \\
MJPL & Mamuna (MMN) & $47: 46$ \\
LSM & Mamuna (MMN) & $25: 54$ \\
NDS & Mamuna (MMN) & $33: 46$ \\
CMDS & Mamuna (MMN) & $30: 12$ \\
\hline TOTAL & \multicolumn{2}{|}{} \\
\hline
\end{tabular}

\subsubsection{Fenômenos escolhidos}

Após a transcrição dos dados, assim como nos dados das análises iniciais, busquei um fenômeno que fosse relevante para o estudo. De modo interessante, os fenômenos de variação na marcação de número e gênero no sintagma nominal não foram encontrados nessas comunidades; quando muito, ocorreram de forma marginal.

Não obstante, os dados apresentaram um fenômeno de variação de número nos verbos quando ocorrem com a primeira e com a terceira pessoa do plural, fenômeno este já amplamente estudado por diversos linguistas. Porém, os dados dessas comunidades apresentaram uma particularidade, a marcação intermediária de plural - noção que será explicitada ao longo da tese - ocorrendo em grande quantidade, gerando, inclusive, consequências sintáticas.

O fenômeno escolhido para a presente tese foi o da variação verbal na marcação de terceira pessoa do plural, diferentemente da tese inicial, que se debruçava sobre o domínio nominal. A variação na marcação de concor- 
dância verbal na primeira pessoa do plural, que também foi identificada nos dados, ficará para um momento posterior de análise.

\subsection{Breves considerações}

Neste capítulo foi apresentado o primeiro corpus com o qual trabalhei, assim como os fenômenos inicialmente estudados e, de modo breve, algumas das análises realizadas. Expus, ainda, os motivos que me levaram a mudar de corpus e de objeto de análise, o que ocorreu durante a viagem de campo realizada no Maranhão em julho de 2016.

Conforme mencionado no decorrer do capítulo, é importante para o pesquisador que vai fazer uma viagem de campo para coletar de dados ter sempre um Plano B, pois pode ser que - e em geral é o que acontece não saia como planejado, haja vista que trabalhamos com pessoas e sempre dependemos da disponibilidade e boa vontade delas.

A metodologia de tratamento dos dados, o programa utilizado para as transcrições a as normas seguidas também foram expostos, assim como os fenômenos escolhidos para esta segunda etapa. Da mesma forma como procedido com o primeiro corpus, dado o fato de não conhecer previamente a fala da comunidade, os fenômenos foram selecionados após as transcrições e análise dos dados.

Diferentemente da primeira etapa na qual me debrucei sobre um fenômeno na esfera nominal, nesta segunda selecionei, ou melhor, os dados me levaram a selecionar um fenômeno na esfera verbal, mais especificamente, a variação na concordância verbal, contudo, logo no início já foi possível perceber que a análise não se daria nos termos tradicionais em que este fenômeno vem sendo estudado. 


\section{Capítulo 3}

\section{O contato linguístico e o contexto histórico de formação do PB}

\subsection{O contato linguístico}

Os estudos sobre o contato linguístico têm ganhado espaço dentro da Linguística. Dentre os diversos motivos pelos quais as temáticas de contato linguístico têm se tornado importante, Mello et al. (2011:9) apontam quatro:

- a relevância cada vez maior que os estudos históricos têm dado ao contato na formação das línguas;

- a globalização e a intensificação do contato entre países distantes faz com que as dinâmicas de contatos linguísticos aumentem e fiquem mais complexas;

- a intensificação dos fenômenos migratórios que envolve novas e complexas direções; e

- o reconhecimento de que o monolinguismo é mais a exceção do que a regra e que algum tipo de relação com mais de uma variedade linguística envolve a grande maioria da população do planeta.

Diante do crescente interesse em relação ao contato linguístico, Negrão \& Viotti (2012) chamam a nossa atenção para a necessidade de abrir espaço para o estudo social do português brasileiro e para a realização de uma História Linguística dele, não no sentido da Linguística Histórica mas, sim, no sentido de reconstruir a ecologia de contato existente no início da colonização brasileira entre os falantes das diferentes línguas que aqui coexistiam. Além disso caberia, igualmente, recuperar o conjunto de traços 
linguísticos formados a partir desse contato, levando em conta a participação das diferentes línguas que contribuíram para a formação do português brasileiro.

As autoras argumentam em favor de uma nova linha de pesquisa intitulada História Linguística com caráter multidisciplinar. Nessa perspectiva, as análises levam em conta os fatos históricos, econômicos e sociais do Brasil, além de fatores geográficos e políticos. A inclusão desses fatores na análise visa, segundo Negrão \& Viotti (2012: 311), a "uma explicação mais abrangente para o conjunto de fenômenos linguísticos que têm sido apontados como caracterizadores do português brasileiro".

Diante disso, a proposta das autoras é de dar maior ênfase à elaboração de uma reconstituição histórica das relações socioeconômicas que estavam subjacentes às interações linguísticas que ocorriam no Brasil no período colonial. Igualmente, o diálogo com a História proveria material para essa reconstituição e isso permitiria levantar hipóteses sobre alguns fenômenos do português brasileiro que o diferem do português europeu. Por trás dessa busca estaria o questionamento do porquê, não obstante a desproporção demográfica entre brancos e não brancos e uma política de escolarização tardia (século XIX) durante o período colonial, a maioria dos processos de substituição linguística se deu em direção ao português.

As autoras admitem, contudo, que para a elaboração dessa História Linguística é necessário adotar uma teoria de mudança linguística que abarque essas questões translinguísticas. A teoria desenvolvida por Mufwene (2001, 2008) parece dar conta dessas questões.

\subsubsection{Evolução das línguas como especiação}

A ideia geral da teoria desenvolvida por Mufwene $(2001,2008)$ seria a de que toda mudança linguística advém do contato entre diferentes idioletos. Para o autor, a parte mais significativa do contato começa entre indivíduos em vez de populações, pois a coexistência de duas populações numa mesma área geográfica não é uma condição suficiente para o contato entre as línguas.

O contato de diferentes variedades produziria um "feature pool", ou banco de traços. Não haveria, contudo, uma proporção particular entre input e output do número de variedades. O que importa, neste caso, é que as variedades de input e output não apresentariam estruturas idênticas.

Essa situação do contato colocaria diferentes variedades e, consequentemente, os diferentes traços / características dessas variedades em competi- 
ção. Nessa situação os falantes selecionariam — não de modo consciente as características mais relevantes para eles.

De acordo com a abordagem do banco de traços, os membros de uma comunidade de fala, especialmente os que interagem um com outro, contribuem com diferentes modelos de pronúncia, de material lexical, de modelos gramaticais e de restrições pragmáticas ao banco de traços. Embora os falantes selecionem suas características do mesmo banco, eles não selecionam as mesmas variantes e, mesmo que selecionassem, não as recombinariam da mesma maneira em seus idioletos.

A seleção seria restringida pelas ecologias internas e externas específicas da interação linguística. A externa, que é a ecologia socioeconômica, imporia um ranking particular de variantes que seriam sensíveis às seleções feitas pelos falantes. A congruência, que favorece características compartilhadas pelas variedades em contato, seria, ela mesma, um fator que direcionaria a seleção.

As mudanças que afetam a língua de uma comunidade seriam o acúmulo e a convergência de seleções feitas repetidamente pelos falantes individuais durante seus atos comunicativos.

As escolhas seriam influenciadas por quando os falantes adquiriram a língua e quem interagia com eles. Esses fatores, a saber, o ambiente social e a rede de comunicação, são o que Mufwene chama de ecologia da linguagem.

Assim como na recombinação de genes, as unidades e os princípios selecionados das diferentes variedades seriam reestruturados dentro de um novo sistema. Nesse caso, assim como no desenvolvimento das línguas românicas, quando do contato entre o latim e as línguas célticas, bem como no desenvolvimento do inglês pelo contato com as línguas germânicas, a seleção teria sido feita de alternativas em competição. A competição toma lugar onde há variação entre parâmetros fonológico, morfológico, sintático ou semântico. Competição e seleção seriam, então, inerentes à dinâmica da evolução das línguas.

Assumindo um banco de traços do qual cada idioleto e, por extrapolação, cada novo estado da língua comum extrai unidades e princípios e os recria em um novo sistema, cada língua seria híbrida em algum sentido.

Em suma, a ideia geral presente no pensamento de Mufwene é a de que toda mudança linguística seria engatilhada através do contato e isso colocaria em "pé de igualdade" todas as línguas naturais. O que as diferenciaria seriam os aspectos sociais e históricos, ou seja, a ecologia particular a cada situação de contato de línguas.

Negrão \& Viotti (2012) nos alertam que analisar a mudança linguística dentro dessa perspectiva teórica implica um conhecimento relevante no que diz respeito à história das comunidades de fala, dos povos, das relações 
estabelecidas e, também, da posição dos indivíduos na história de suas comunidades.

Em Miranda (2013), sugeri que línguas como o caboverdiano, sãotomense e principense ajudariam a entender certas mudanças ocorridas no português brasileiro, dadas algumas semelhanças existentes entre elas no que concerne ao contexto de formação. Levando em conta o fato de que o português que foi levado tanto para o Brasil quanto para Cabo Verde ou ainda para São Tomé e Príncipe foi o português europeu do século XVI e, ainda, que existiu uma situação de contato entre esse português e outras línguas - africanas no caso de Cabo Verde e São Tomé e Príncipe e línguas africanas e indígenas no caso do Brasil - nesses diferentes países, faria mais sentido aproximar essas diferentes línguas (português brasileiro, caboverdiano, são-tomense e principense) entre si, do que compará-las ao português europeu, por exemplo, sobretudo ao português europeu contemporâneo.

O português europeu contemporâneo sofreu uma mudança em relação ao português que foi levado às diferentes colônias no século XVI como, por exemplo, a expressão do aspecto progressivo. Logo, se há alguma relação entre o português brasileiro ou o caboverdiano e o PE, seria com o português quinhentista.

É fundamental trazer à tona também a proposta de Petter (2008). A autora mostra que, através da história do contato e dos aspectos linguísticos comuns entre o português moçambicano (PM), o português angolano (PA) e o português brasileiro (PB), é possível levantar a hipótese de um continuum entre essas variedades que derivam de uma origem comum, a saber, a expansão da língua portuguesa num contexto de colonização. Esse contínuo resultaria de uma "mistura" de línguas locais com uma língua dominadora comum. A autora observa ainda que:

Desse contexto decorre um estatuto linguístico específico para a língua portuguesa em cada território onde ela é falada, que não impede, no entanto, a existência de um continuum entre as variedades linguísticas selecionadas (Petter, 2008: 12).

O contínuo se daria na medida em que essas três variedades do português revelariam momentos históricos diferentes do contato entre o português europeu e diversas línguas africanas, somadas às línguas indígenas no caso do Brasil. Aqui, no Brasil, teríamos um primeiro momento desse contato, iniciado no século XVI, enquanto as variedades africanas revelariam momentos posteriores, uma vez que, lá, o português europeu foi introduzido apenas no século XIX. Logo, alguns fatos de língua presentes 
no PA e PM mostrariam um "momento" pelo qual o PB já teria passado no que diz respeito às mudanças advindas do contato.

Embora hoje no Brasil não se falem mais línguas africanas e não se possa postular a hipótese de que o português seja adquirido como segunda língua pela maioria da população, os dados históricos e os fatos linguísticos observados em Angola e Moçambique, onde as línguas africanas ainda convivem com o PE, podem indicar que essa teria sido uma das situações que provocou as variações ainda observadas hoje, após mais de quatro séculos do contato do português com as LBs no Brasil ${ }^{1}$ (Petter, 2008: 193).

Petter (2008: 66) observa ainda que

a língua portuguesa sempre foi a língua alvo de todos os falantes, mesmo que em alguns momentos e em algumas localidades uma língua - indígena (a língua geral) ou africana (o quimbundo, o iorubá, ou a língua geral de mina) - pudesse assumir o estatuto de língua veicular, configurando uma situação de bilinguismo dos falantes de português.

É preciso ressaltar que a autora não afirma que a direção da mudança no PA e no PM será a mesma tomada pelo PB, pois há fatores de ordem linguística e social diferentes daqueles que atuaram aqui no Brasil que podem interferir nos processos de mudança. O que se deve fazer é estar atento aos processos e à situação de contato existentes nas variedades africanas, pois podem fornecer dados importantes para o entendimento das especificidades encontradas no PB (Petter, 2008: 193).

\subsubsection{De volta à História Linguística do português brasi- leiro}

Em seu texto a respeito do estabelecimento de uma História Linguística do português brasileiro, Negrão \& Viotti (2012) delineiam as bases de um projeto de investigação sobre o contato, tomando como base a teoria de mudança linguística de Mufwene $(2001,2008)$. As autoras nos alertam que, para a investigação do português brasileiro, é preciso centrar-se em uma análise criteriosa do contato estabelecido entre:

\footnotetext{
${ }^{1}$ As línguas bantas constituem a maior parte da família benue-congolesa, do tronco linguístico nigero-congolês e são faladas no sudeste do continente africano, na África Central e na Âfrica do Sul (Petter, 2015: 60).
} 
i. as variedades do português que chegaram no Brasil, nos diferentes fluxos da empresa colonial, levando em conta que esse português já havia sido exposto a um contato com grande número de línguas africanas;

ii. as incontáveis línguas indígenas nativas aqui encontradas; e

iii. todas as línguas e dialetos que foram trazidos pelos africanos para o Brasil, das mais diversas partes do continente africano, em diferentes momentos e configurações do tráfico.

Os pontos arrolados devem ter início, na visão das autoras, em uma profunda investigação da história da colonização e das relações socioeconômicas subjacentes às interações entre os membros da população colonial.

Na esfera linguística caberia, então, verificar os traços linguísticos das variedades em competição nesse ambiente, voltando-se para as propriedades gramaticais das línguas que participaram da formação do português brasileiro, analisando, desta feita, não só os traços das línguas participantes, mas também a possível congruência entre os traços das línguas em contato.

As autoras observam, porém, que dentro dessa perspectiva, a questão da busca por evidências que apontam de maneira exata para as línguas que participaram em uma determinada situação de contato pode ser modalizada. Para entender as situações de contato das quais emergiram as línguas coloniais, ou mesmo as ditas línguas crioulas, é possível trabalhar com noções mais amplas, como por exemplo traços comuns de famílias de línguas, ou com características areais (Negrão \& Viotti, 2014: 302-3).

Ademais, diante desse pensamento, estudar o português brasileiro a partir dessa perspectiva reorientaria os debates existentes sobre a participação das línguas africanas e indígenas na emergência das características que distinguem o português brasileiro da variedade europeia. As autoras propõem, então, uma investigação de dupla face: iniciando com uma profunda investigação da história da colonização e das relações econômicas subjacentes às interações entre a população da época. Em igual passo, o estudo das propriedades gramaticais das línguas em contato para delas extrair os possíveis traços em competição que integram o banco de traços.

Ainda, nas palavras de Negrão \& Viotti (2012: 334 e 35):

Só assim será possível, a nosso ver, chegar a um entendimento mais claro do que foram os resultados do contato entre o português europeu com as línguas indígenas da costa, nos primeiros anos de exploração. Só assim poderemos delinear o que foi a 
chamada língua geral paulista, fazendo hipóteses sobre as línguas que participaram de sua formação, sobre a extensão de seu uso no território nacional, e sobre a distância que ela mantinha em relação à língua vernacular que emergia nos centros urbanos da costa brasileira. Só assim vamos poder levantar hipóteses sobre as relações entre a língua geral paulista e a língua geral amazônica, tanto de um ponto de vista linguístico quanto de um ponto de vista sócio-histórico. Só assim vamos poder buscar uma reconstituição das interações linguísticas entre falantes de línguas europeias, de línguas gerais e de línguas africanas, avançando nosso conhecimento sobre a formação do português brasileiro.

Não devemos esquecer também que os resultados obtidos sobre a emergência dessas línguas, e de certas características do português tomadas dentro dessa perspectiva de contato, são hipotéticos: por mais meticulosa que seja a reconstituição dos fatos, não será possível reconstituir com exatidão a ecologia de contato existente entre o português, as línguas africanas e as línguas indígenas na época colonial (Negrão \& Viotti, 2014).

\subsection{Contexto histórico da formação do PB}

Diversos autores, ao tratar da formação do português brasileiro, apresentaram o contexto histórico existente na época da colonização do país (Lucchesi, 2009b; Mussa, 1991; Bonvini, 2008a; Ribeiro, 1897; Mattoso, 1979; Vianna Filho, 1946; Raimundo, 1933; Mendonça, 1933, entre outros).

Isso posto, apresento o contexto de formação do português brasileiro de maneira global, dando ênfase posteriormente ao contexto de formação do Maranhão, objeto de análise da presente tese, atentando-me a um ou outro ponto pertinente à discussão que será empreendida posteriormente, pois, conforme observado na seção anterior, não seria possível falar sobre o contato existente entre as diferentes línguas no período colonial sem passar pelas questões históricas pertinentes a este tema.

Antes da chegada dos africanos, o maior contingente populacional era composto pelos indígenas que aqui existiam bem antes da chegada dos portugueses. Nas primeiras décadas da colonização, mais precisamente, de 1540 a 1570, os indígenas foram os principais produtores de açúcar no Brasil, compondo quatro quintos da força de trabalho no Nordeste e quase toda a mão de obra nos engenhos que se desenvolviam mais ao sul, na região do Rio de Janeiro (Luna \& Klein, 2010). 
Os índios brasileiros eram divididos, grosso modo, entre os tupi-guarani e os tapuia, os primeiros ocupando o litoral e os tapuia o interior. Ambos compreendiam muitas nações e tribos e eram, em um primeiro momento, inimigos. Após a vivência com os europeus, acabou ocorrendo uma fusão entre esses índios (Lima, 1981:23).

As doenças endêmicas trazidas pelos portugueses se tornaram verdadeiras epidemias entre a população indígena, dizimando centenas deles. Em 1560, no auge da utilização da mão de obra indígena, eclodiu um grande surto de varíola entre essa população. Estima-se que esta epidemia ceifou a vida de cerca de 30 mil índios que viviam nos engenhos e nas aldeias missionárias.

Relativo à população europeia que veio para o Brasil, em especial os portugueses, merece destaque o fato de que a maioria pertencia à camada popular, em grande parte composta por homens, de origem rural e muito provavelmente não letrados, considerando que o letramento em Portugal começou a difundir-se, aos poucos, no século XVI (Mattos e Silva, 2004: 74). A mão de obra portuguesa que chegou aqui era oriunda de diferentes localidades como Madeira, Açores, Porto, Alentejo, Minho e Lisboa. Entre 1538 e 1600, os europeus representavam cerca de 30\% da população; esse índice aumentou para $41 \%$ na segunda metade do século XIX.

A data exata de chegada dos primeiros africanos ao Brasil é incerta, contudo, sabe-se que após as tentativas frustradas de escravização dos indígenas entre 1540 e 1570, aliadas à próspera riqueza dos senhores de engenho brasileiros, deu-se o início da importação de africanos ao Brasil. Em 1580, Pernambuco já registrava a quantidade de 2 mil africanos trabalhando na produção de açúcar. Os trabalho indígena foi sendo substituído pela mão de obra dos africanos escravizados que, em 1620, já compunham a maioria dos trabalhadores na produção açucareira (Luna \& Klein, 2010).

É essencial destacar que, embora existam diversos estudos que tentem sistematizar as informações sobre o tráfico de africanos para o Brasil, ele não deve ser entendido em ciclos bem definidos. Este quadro, assim como o quadro do contato linguístico que se desenvolverá no país àquela época, é complexo, composto por diferentes agentes, com diferentes interesses e papéis dentro da conjuntura esboçada neste contexto. Almeida (2014) apresenta algumas tendências gerais do tráfico de africanos, as quais reproduzo a seguir:

- 1500 - 1580: nesse período a grande fornecedora de africanos escravizados foi a Alta Guiné, que compreende a região entre o rio Senegal e a atual Libéria. 
- 1580 - 1690: no final do XVI e decorrer do XVII a grande parte dos africanos trazidos para o Brasil era originária da África Centro-Ocidental. Com a fundação de Luanda, em 1576, e a eclosão das guerras angolanas, as zonas de comércio e escravidão deslocaram-se para o sul do reino do Congo. Na segunda metade do século XVII, iniciou-se o comércio na África Ocidental, em especial na Baía de Benin.

\begin{tabular}{|l|c|}
\hline África Centro-Oriental & $93 \%$ \\
África Ocidental & $6 \%$ \\
África Oriental & $1 \%$ \\
\hline \hline Total de africanos & 667.778 \\
\hline
\end{tabular}

Tabela 3.1: Total de africanos que desembarcaram no Brasil no período de 1580 a 1690. Fonte: Almeida (2014:354).

- 1690 - 1808: nesse período há duas rotas paralelas para abastecer a zona açucareira e a área de extração de metais e pedras preciosas, a África Ocidental e a Centro-Ocidental. Nessa época, o tráfico com a Baía de Benin tornou-se bastante expressivo. É possível dividir este período da seguinte maneira:

$1691-1750$

\begin{tabular}{|l|c|}
\hline África Centro-Ocidental & $55 \%$ \\
África Ocidental & $45 \%$ \\
\hline \hline Total de africanos & 1.034 .171 \\
\hline
\end{tabular}

Tabela 3.2: Total de africanos que desembarcaram no Brasil no período de 1691 a 1750. Fonte: Almeida (2014:354)

$1751-1808$

\begin{tabular}{|l|c|}
\hline África Centro-Ocidental & $68 \%$ \\
África Ocidental & $31 \%$ \\
África Oriental & $1 \%$ \\
\hline \hline Total de africanos & 1.371 .489 \\
\hline
\end{tabular}

Tabela 3.3: Total de africanos que desembarcaram no Brasil no período de 1751 a 1808. Fonte: Almeida (2014:355) 
- 1808 - 1850: o tráfico alcançou níveis altíssimos nesse período impulsionado pela abertura dos portos e pela expansão cafeeira no Sudeste brasileiro. As regiões do rio Congo e de Benguela, no interior da África Centro-Ocidental, passaram a ser fundamentais para o comércio do tráfico de africanos, a despeito do fato de Luanda ter tido um papel importante até 1840 . Nesse período cresceu vertiginosamente o tráfico em Moçambique.

\begin{tabular}{|l|c|}
\hline África Centro-Ocidental & $71 \%$ \\
África Ocidental & $15 \%$ \\
África Oriental & $14 \%$ \\
\hline \hline Total de africanos & 1.832 .648 \\
\hline
\end{tabular}

Tabela 3.4: Total de africanos que desembarcaram no Brasil no período de 1808 a 1850. Fonte: Almeida (2014:355)

Sobre a quantidade total de africanos trazidos para o Brasil durante o tráfico, o banco de dados do projeto Slave Voyages ${ }^{2}$, presente no site http: //www. slavevoyages.org/ apresenta a tabela 3.5, a seguir. Não obstante a aparente precisão dos números, estas informações ainda representam estimativas.

\footnotetext{
${ }^{2}$ Este projeto possui o Banco de Dados do Tráfico Transatlântico de Escravos que reúne informações sobre aproximadamente 36.000 viagens da África para as Américas. Estimase que um total de 12,5 milhões de africanos tenham sido embarcados à força entre os séculos XVI e XIX. O projeto é coordenado por David Eltis, professor de História na Universidade Emory, Atlanta, Georgia e por Martin Halbert, também da Universidade Emory, envolvido em programação digital e divisão de sistema, e recebe a colaboração de diversos profissionais de diferentes áreas do conhecimento.
} 


\begin{tabular}{|l|r|}
\hline Período & Total \\
\hline \hline $1501-1525$ & 7.000 \\
$1526-1550$ & 25.387 \\
$1551-1575$ & 31.089 \\
$1576-1600$ & 90.715 \\
$1601-1625$ & 267.519 \\
$1626-1650$ & 201.609 \\
$1651-1675$ & 244.793 \\
$1676-1700$ & 297.272 \\
$1701-1725$ & 474.477 \\
$1726-1750$ & 526.696 \\
$1751-1775$ & 528.693 \\
$1776-1800$ & 673.167 \\
$1801-1825$ & 1.160 .601 \\
$1826-1850$ & 1.299 .969 \\
$1851-1875$ & 9.309 \\
\hline \hline Total & 5.848 .266 \\
\hline
\end{tabular}

Tabela 3.5: Total de africanos que desembarcaram no Brasil no período de 1500 a 1875. Fonte: Projeto Slave Voyages.

As informações da tabela mostram que no período de 1501 a 1875, vinte e cinco anos após a proibição do tráfico de africanos, o total estimado de negros escravizados trazidos para o Brasil é de um pouco mais de 5 milhões e 800 mil pessoas. Nota-se inclusive uma drástica diminuição logo após a proibição do tráfico pela Inglaterra em 1850. Se nos 25 anos anteriores à proibição do tráfico o número de africanos que chegaram ao Brasil passou de um milhão e duzentos e noventa mil, o maior número desde o início da colonização, nos 25 anos posteriores à proibição do tráfico, este número passou para pouco mais de 9 mil africanos, o que representa uma queda de um milhão e duzentos mil.

Também não há consenso no que concerne às regiões de origem desses africanos trazidos para o Brasil. Almeida (2014) aponta para um total de pouco mais de 1 milhão 180 mil vindos da África Ocidental, compreendendo as regiões da Senegâmbia e ilhas atlânticas, Serra Leoa, Costa do Barlavento, Costa do Ouro, Baía de Benin e Baía de Biafra, um total de mais de 3 milhões e 300 mil africanos oriundos da África Centro-Ocidental e pouco mais de 270 mil vindos da África Oriental. 


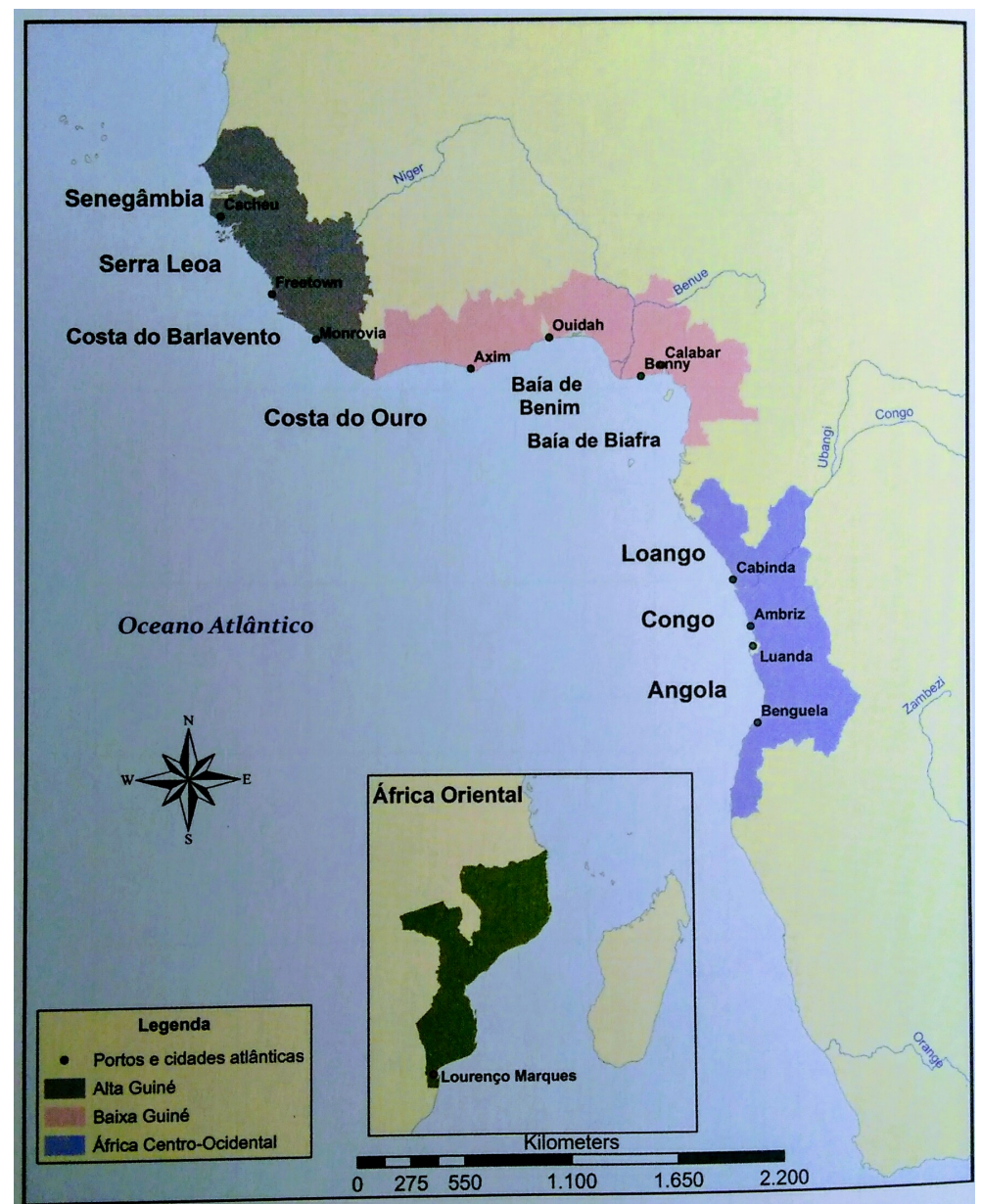

Figura 3.1: Tráfico de escravos: regiões e portos. Fonte: Almeida (2014:358).

Luna \& Klein (2010), com base nos dados do projeto Slave Voyages, apresentam um total de 5.479 .583 pessoas vindas da África para o Brasil no período de 1561-1850. Desse total, 70,1\% eram oriundos da região AngolaCongo; $18 \%$ do Golfo de Benin; 5,7\% de Moçambique; 2,4\% do Golfo de Biafra; 2,2\% da Senegâmbia; 1,3\% da Costa do Ouro; 0,2\% de Serra Leoa.

No que diz respeito à tentativa de diversificar a origem dos diferentes africanos para impedir rebeliões, esta veio mais dos proprietários do que dos traficantes. Estes compravam escravos onde havia oferta, e a disponibilidade dependia exclusivamente das regiões da África que podiam 'oferecer' essa mão de obra. Ademais, alguns eventos podem ter proporcionado uma grande 'oferta' de africanos de determinada região como, por exemplo, diversas guerras ocorridas em meados do século XVI que ocasionaram o declínio do império Wolof, bem como o colapso do império 
Oyo no final do século XVIII, o que levou muitos iorubás ao cativeiro (Luna \& Klein, 2010).

Em vias de fato, os fazendeiros não tinham como determinar as regiões de origem dos cativos que adquiriam, considerando inclusive o fato de que a muitos deles era atribuído como origem o porto de onde embarcaram e não necessariamente a região onde foram capturados, ou ainda por muitos deles não saberem identificar exatamente sua origem. Mesmo existindo essa tentativa, não se deve esquecer o fato de que boa parte dos africanos era bilíngue ou multilíngue, o que faria com que essa tentativa, de todo modo, não surtisse o efeito esperado.

Relevante observar o fato de que muitos dos africanos trazidos para o Brasil chegavam doentes e morriam logo após a chegada, além é claro das mortes ocorridas durante a travessia. Embarcações que vinham de Moçambique, por exemplo, por realizar um trajeto mais longo, tinham um índice de mortalidade maior do que as embarcações vindas da costa oeste, por exemplo.

Os africanos que vieram para o Brasil por meio do tráfico ocupavam diferentes atividades, a mão de obra africana era utilizada não só na produção açucareira ou na mineração no século XVIII, mas estava dispersa em diferentes atividades nas cidades, como carregadores, escravos de ganho ${ }^{3}$, serviços domésticos, artesãos, pedreiros, sapateiros, funileiros e em outras atividades rurais como agricultura e pesca. Isso sugere que eram diversos os espaços sociais ocupados pelos africanos escravizados, não estavam apenas isolados no trabalho das grandes plantações ou na mineração, mas participavam amplamente da vida social como um todo, considerando sempre, é claro, o papel que eles ocupavam na sociedade, vistos como propriedades ou coisas.

Não se deve esquecer que, mesmo com algumas especificidades e complexidades, o sistema escravista brasileiro foi sempre pautado pela violência, física, emocional ou psicológica, exposta ou velada. Trazer à tona o fato de que os africanos estavam inseridos em diferentes atividades econômicas ou evidenciar maior participação deles na vida social brasileira na época colonial não é, de forma alguma, atenuar ou mascarar a violência perpetrada por esse regime que durou tantos anos no Brasil e que ainda traz consequências para a população negra brasileira.

Na zona rural, o trabalho diário atingia, em média, de quinze a dezoito horas. As senzalas ficavam próximas à residência do fazendeiro para

\footnotetext{
${ }^{3}$ Os escravos de ganho vendiam produtos ou serviços por conta própria. Os proprietários alugavam seus cativos a terceiros para todo o tipo de trabalho e recebiam uma quantia fixa mensal e o escravizado não tinha qualquer autonomia nesse processo (Luna \& Klein, 2010: 150).
} 
que fosse possível uma maior fiscalização. A alimentação consistia basicamente em feijão, angu e farinha de mandioca, às vezes tinha um pedaço de carne-seca. Em alguns casos, eles eram alimentados apenas de feijão, sem qualquer condimento. $\mathrm{O}$ senhor representava toda a autoridade existente, jurídica, civil e religiosa (Costa, 1997).

Dada a intensa miscigenação, mestiços e pardos logo formam a maioria da sociedade, tanto como escravos quanto como forros e pessoas livres. A partir da década de 1870, os negros crioulos, isto é, nascidos no Brasil, passaram a compor a maior parte da população escrava.

Durante o período de grande atividade econômica, em todas as regiões do país e em todas as atividades era utilizada de maneira generalizada a mão de obra africana. Após o fim do tráfico, em 1850, os cativos africanos concentram-se nas regiões de maior desenvolvimento econômico. Com a diminuição da chegada de mão de obra trazida da África, ocorreu também o fenômeno de migração interna, em que os escravizados eram deslocados para as regiões com maior demanda.

Concernente ao crescimento demográfico da população africana aqui no Brasil, a baixa percentagem de mulheres trazidas para cá afetava esse número. Uma boa parte das mulheres que desembarcava já quase não estava mais na fase reprodutiva e o número de crianças trazidas também era baixo. Esse quadro impedia que a população africana mantivesse seu número por meio de novos nascimentos (Luna \& Klein, 2010).

Não obstante todos esses fatos, a taxa de natalidade dos escravizados aqui no Brasil era relativamente alta, 35 a 45 por mil. Contudo, ela foi insuficiente para manter a população devido ao grande número de homens trazidos da África, à elevada taxa de mortalidade dos africanos, e também ao elevado índice de morte dessas crianças nascidas em situação de cativeiro: cerca de um terço das crianças nascidas morria antes de completar um ano de vida e pouco menos da metade não vivia mais do que cinco anos de idade. A expectativa de vida dos meninos que não morriam antes do primeiro ano de vida ou antes dos cinco anos era de 38,4 anos, e a das meninas era de 39 anos (Luna \& Klein, 2010).

Sobre a dita baixa expectativa de vida dos africanos nas lavouras, que ficou por algum tempo conhecida ser de sete anos, diferentes estudos apontam que a média de vida dos africanos trazidos para o Brasil era de quinze (Costa, 1997:302) a vinte e poucos anos (Luna \& Klein, 2010: 185). Apesar dessa aparentemente elevada expectativa de vida, não se deve deixar de lado o fato de a população escravizada estar sujeita a diversas doenças e situações de risco que poderiam levar à morte, tanto envolvendo doenças adquiridas durante o trabalho quanto relacionadas à má alimentação, bem 
como mortes consequentes dos castigos físicos recebidos e dos acidentes de trabalho.

\subsection{O contato no português brasileiro}

Sobre os estudos em relação às possíveis origens do português brasileiro, é importante ter em mente que não estão limitados apenas às versões que defendem a deriva linguística de um lado ou a crioulização de outro ${ }^{4}$. Há visões intermediárias que entendem que

o português brasileiro é sem dúvida uma das variedades de uma abstração linguística convencionalmente chamada de língua portuguesa, marcada, porém, pela sua história de aquisição como segunda língua por milhares, senão milhões, de pessoas de diferentes proveniências linguísticas e pelo contato e renovação linguística ao longo de séculos (Mello, 2011: 174).

Dentro do contexto de contato linguístico delineado nos primeiros anos de colonização do Brasil que possibilitou a formação do PB, tanto indígenas quanto africanos foram, paulatinamente, abandonando suas primeiras línguas e adotando o português como língua veicular. Esse português adquirido como segunda língua por adultos que não possuía grande disponibilidade de modelos acessíveis de L1 sofreu modificações e essas mudanças influenciadas pelas L1s - indígenas e africanas - dos falantes, em contato com o português falado pelos colonos, foram se consolidando ao longo do tempo (Mello, 2011).

É crucial observar que a língua portuguesa que chegou aqui no Brasil na época da colonização já havia entrado em contato com outras línguas, pois Portugal já tinha um longo histórico de comunicação com outros povos, a exemplo do contato com os árabes quando o país estava ocupado pelos califados árabes durante os séculos VIII ao XI e na Idade Média, época em que os portugueses participaram ativamente das cruzadas (Naro \& Scherre, 2007; Negrão \& Viotti, 2014).

Outro fato relevante é que a língua portuguesa que veio para cá não foi a fala culta, mas sim a popular, de diferentes partes de Portugal, e o quadro que se delineava, na época da colonização, é o de diferentes línguas se influenciando mutuamente, em especial pelo aprendizado de segunda língua por adultos. Naro \& Scherre (2007) apontam que parece ter sido

\footnotetext{
${ }^{4}$ Para uma exposição e reflexão geral sobre essas diferentes hipóteses e, ainda, sobre a hipótese de transmissão linguística irregular, ver Lins (2009).
} 
inevitável, nesse contexto, a existência de pelo menos duas línguas gerais de base africana.

Como já mencionado, esta tese parte da ideia de que as características particulares existentes no português brasileiro são oriundas do contato entre o português europeu vindo para cá na época da colonização, as diversas línguas indígenas aqui já existentes e as diferentes línguas africanas para cá transplantadas, e é sempre digno de nota o fato de que contato não é sinônimo de crioulização (Parkvall \& Álvarez López, 2003). Dentro da perspectiva de contato adotada, todas as línguas do mundo mudam por meio do contato, independente se são consideradas ou não línguas crioulas ${ }^{5}$.

Sobre a negação da participação das línguas africanas no processo de constituição do PB, trago à baila a citação de Mussa, que ilustra bem a questão

É impossível desconsiderar, como se vem fazendo, a participação das populações africanas no conjunto da história linguística brasileira. Do ponto de vista de uma dinâmica histórica, o português dos africanos e o português europeu detêm o mesmo valor, não podendo ser tomados isoladamente como ponto de partida exclusivo (Mussa, 1991: 244).

Em consonância com essa linha de pensamento, Mattos e Silva (2004: 106) observa que os africanos e os afrodescendentes foram os principais agentes na difusão do português no território brasileiro, levando em conta a mobilidade dessa população à época da colonização. Tomando por base dados de Mattoso (1979: 23-24;53-54), Mattos e Silva considera a respeito dos africanos:

Nos séculos XVI e XVII, se concentravam nas lavouras da canade-açúcar nas capitanias litorâneas de Pernambuco, Bahia e Rio de Janeiro. Nos séculos XVII e XVIII, transitou grande parte para as áreas de mineração do ouro e de diamantes, nos interiores paulistas, no centro e centro-oeste do Brasil. Do século XVIII para o XIX, diminuindo a mineração referida, em boa parte voltam para o litoral do Rio de Janeiro e de São Paulo, onde ocorre um novo impulso açucareiro. No século XIX, concentram-se no Vale do rio Paraíba do Sul, em áreas paulistas, do Rio e de Minas Gerais, locais em que se explorou o novo ouro, o café. Acompanhando seus senhores, seguem para o Maranhão, para

\footnotetext{
${ }^{5}$ Sobre a visão que adoto a respeito das línguas crioulas, ver Miranda (2013).
} 
a colheita do algodão e fumo, também para a Amazônia, para a exploração de especiarias. Desde o século XVI, se dispersam os escravos e também os indígenas pelas imensas regiões pastoris interioranas, deslocando-se, a partir do século XVII, aos interiores nordestinos (Mattos e Silva, 2004: 129).

O fato de os africanos e afrodescendentes terem sido sempre a maioria durante o período colonial e pós-colonial fará com que eles sejam os grandes difusores da língua portuguesa pelo país. Não esquecendo o fato de que esses africanos aprenderam o português como segunda língua em uma situação não propriamente adequada de aprendizado.

A noção ora apresentada é diferente da transmissão linguística irregular advogada por Lucchesi (2000, 2006, 2009b, 2012), entre outros. Nessa visão, a aquisição de segunda língua em condições irregulares levaria à erosão da gramática da língua alvo nessas variedades de segunda língua formadas. Na visão de Mufwene (2001, 2008), que adoto na tese, o que ocorre é uma competição e seleção de traços que podem, inclusive, resultar de uma convergência desses traços fazendo surgir uma característica diferente daquelas de origem, enfim, não ocorre qualquer erosão de gramática, mas sim um processo de contato que leva à mudança linguística.

Uma ecologia semelhante à existente no Brasil colônia é a que se atesta em Angola e Moçambique, por exemplo, em que o português convive com as diferentes línguas faladas nesses países. Gonçalves \& Chimbutane (2004: 2) apontam para a interferência das línguas maternas (L1s) dos falantes - basicamente línguas bantas - no aprendizado do português em Moçambique. As línguas nativas atuam na fixação de novas propriedades gramaticais, como de verbos agentivos e inacusativos, por exemplo. Nas palavras dos autores: "ficou demonstrado que o conhecimento da gramática das LBs por aprendentes de Português como língua segunda (L2) interfere no processamento do input, dando origem a uma nova gramática do Português."

Importante trazer à tona também que, conforme nos lembram Raso et al. (2011:26), a complexidade e as particularidades do contexto sociocultural e linguístico dos primeiros séculos do Brasil colonial talvez não possam ser jamais inteiramente desveladas. O que nos fica são pistas que podem levar a hipóteses de como se dava esse processo de interação linguística e contato entre estes povos. No final, por mais que se tenha informações históricas sobre esse período, as conjecturas levantadas sobre a interação linguística ainda serão hipóteses.

A perspectiva do contato leva em consideração o cenário desse contato, bem como os diversificados inputs das línguas africanas, indígenas e do 
português lusitano. Como um primeiro passo, faz-se necessário traçar quais línguas ou quais famílias de línguas tiveram participação na constituição do PB. Como evidenciado na seção 3.2, grande parte dos africanos trazidos para o Brasil era oriunda da África Ocidental, mais especificamente da região Angola-Congo, em que são faladas as línguas bantas, e a outra região principal foi a austral. Partindo dessas regiões é possível traçar quais as línguas faladas pelos africanos trazidos para o Brasil. Da primeira área temos o tronco nigero-congolês.

O tronco nigero-congolês é o maior do mundo, com 1.524 línguas. Estende-se por grande parte da África ao sul do Saara, inclui quase toda a África ocidental, central, oriental e meridional. Dados recentes apontam que atualmente este tronco possui 470.000 .000 de falantes e as línguas mais faladas são o uólofe, no Senegal; o fula, na região central e ocidental do continente; todas as variedades de mandinga — o bambara, no Mali e o diúla, na África ocidental; o acan, em Gana; o iorubá e o ibo, na Nigéria; o sango, na República Centro-Africana; as línguas do grupo banto como lingala, quimbundo, suaíli, setsuana, quicongo, umbundo, zulu, entre outras (Petter, 2015: 53-54).

Desse tronco, foram transplantadas para o Brasil as seguintes famílias (Bonvini, 2008a: 30-31; Petter, 2011, 2014: 260-1, 345-6):

- atlântica: fula (fulfulde), uólofe, manjaco, balanta;

- mandê (sobretudo o mandinga): bambara, maninca; diúla;

- gur: subfamília gurúnsi;

- cuá (subgrupo gbe): eve, fon, gen, jeje;

- ijoide: ijó;

- benuê-congolesa: dentro da família benuê-congolesa há os grupos:

- defoide: falares iorubás designados no Brasil pelo termo nagô-queto;

- edoide: edo;

- nupoide: nupe (tapa);

- iboide: ibo;

- cross-River: efique, ibíbio. 
Dessa região há ainda o tronco afro-asiático, do qual foi trazida a língua hauçá, da família chádica, e o tronco nilo-saariano, cuja língua transplantada é a canúri, da família saariana. O tronco afro-asiático possui 366 línguas localizadas na África setentrional que se distribuem em seis famílias: berbere, chádico, egípcio, semítico, cuchita e omótico. O tronco nilo-saariano também está localizado nos países da África setentrional; as 198 línguas deste tronco são faladas em 15 países, com a maior concentração genética no Chade, Sudão e Etiópia (Petter, 2015).

Da área austral, vieram línguas essencialmente do grupo banto (tronco nigero-congolês, família benuê-congolesa), limitadas à região da costa oeste (atuais República do Congo, República Democrática do Congo e Angola) e posteriormente estendidas à costa leste, mais precisamente à região de Moçambique. As línguas dessa região são tipologicamente homogêneas, mas faladas pelo maior número de cativos, são elas (Bonvini, 2008a:30-31, Petter, 2011, 2014: 260-1, 346):

- congo (quicongo): quissilongo, quissicongo, quizombo, quissundi ${ }^{6}$ e quivíli, iuoio (fiote), quiombe ${ }^{7}$;

- quimbundo ${ }^{8}$ : quissama, quindongo.

- iaca-holo: iaca, imbangala, chinji;

- chôcue: uchôcue, ochinganguela, chilucazi, luena (luvale);

- luba: chiluba-cassai (lulua);

- lunda: chilunda, urunda;

- macua: omacua;

- umbundo9 $^{9}$ : umbundo, olunianeca;

- cuaniama, indonga: ochicuaniama, cuambi;

- herero: ochiherero.

\footnotetext{
${ }^{6}$ Falada pelos bacongos, região correspondente ao atual reino do Congo.

${ }^{7}$ Faladas em Cabinda e em Loango.

${ }^{8}$ Falada pelos ambundos, na região central de Angola, antigo reino de Ndongo.

${ }^{9}$ Falada pelos ovimbundos na região de Benguela, Angola.
} 


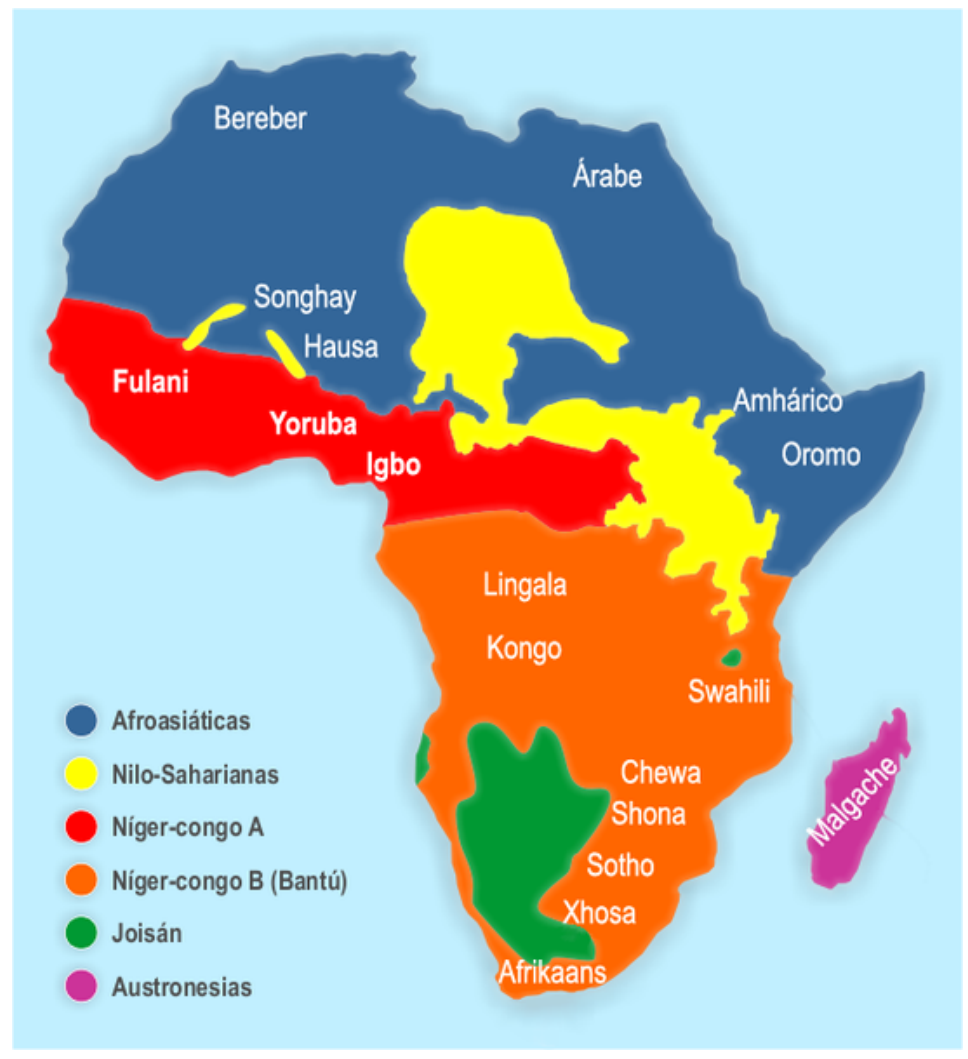

Figura 3.2: Línguas da África: troncos linguísticos.

Fonte: pt.wikipedia.org

Traçar quais línguas foram transplantadas para o Brasil não significa que se deva olhar para os traços de cada uma dessas línguas e tentar reconhecê-los no PB. A complexidade do contexto de contato linguístico não nos permite fazer tal procedimento e tampouco a teoria de contato de Mufwene $(2001,2008)$ apresenta a interação entre as línguas dessa forma.

O reconhecimento das línguas africanas que participaram da ecologia linguística de formação do $\mathrm{PB}$ pode ajudar a reconhecer traços tipológicos ou areais que tiveram parte na constituição da língua falada hoje no Brasil e entender as mudanças que se processaram durante esse contato. Como afirma Petter (2011: 262)

[...] fica difícil tentar comparar traços da fonologia, morfologia ou sintaxe dessas línguas com aspectos considerados particulares do PB. Mas é inegável que o conhecimento dos traços tipológicos dos diferentes grupos linguísticos pode evitar que se façam afirmações apressadas sobre as línguas africanas, como 
aquelas comumente repetidas: "as línguas africanas só têm sílabas CV; não há encontros consonantais; as LAs têm dupla negação" etc.

Não obstante essa dificuldade de precisar as exatas características das línguas africanas que tomaram parte na constituição do português brasileiro, vários foram os autores que trataram da influência ${ }^{10}$ das línguas africanas na formação do PB, trazendo evidências desde o nível lexical até o sintático. Mendonça (1933), ao lado de Rodrigues (1932) e Raimundo (1933), é um dos pioneiros nesse sentido. O autor traz um vocabulário de 375 termos considerados por ele como de origem africana, usados no Brasil ou empregados por escritores brasileiros. Além do significado de cada termo, Mendonça apresenta a língua de origem, a área geográfica em que é falada no Brasil e, em alguns casos, o contexto em que o termo é empregado.

Em A influência africana no português do Brasil, Mendonça (1933) percorre desde a etnografia africana, distinguindo os grupos étnicos, passando pela linguística e a classificação das línguas africanas, até a história do tráfico dos africanos trazidos para o Brasil e a tentativa de estabelecer a origem desses africanos. Sobre a influência das línguas africanas, o autor apresenta questões fonéticas e morfológicas, trazendo uma análise geral sobre a fonética do quimbundo e a influência no PB, bem como a noção de classes nominais e como o português brasileiro foi alterado por elas ${ }^{11}$. O autor não nega, contudo, a participação das línguas indígenas e aponta alguns erros de interpretação que atribuem às línguas indígenas características das línguas africanas.

Em Falares africanos na Bahia: um vocabulário afro-brasileiro, Castro (2001) traz um vocabulário de 3.517 palavras, com 1.322 termos de origem banta, 1.299 do oeste africano, 34 de origem imprecisa e 853 de formação brasileira que, mesmo não sendo de origem africana, seriam pertencentes exclusivamente ao falar baiano, os quais a autora julgou pertinente incorporar

\footnotetext{
${ }^{10} \mathrm{O}$ termo influência, como apontou Bonvini (2002) em Cunha (2003) ao falar do léxico, pode ser metodologicamente inadequado ao falar de interações linguísticas, no entanto, é utilizado na presente tese sem qualquer juízo de valor, especialmente em relação às línguas africanas.

${ }^{11}$ Não me deterei nos detalhes da análise deste autor, pois há diversos estudos recentes que abordam essas questões, inclusive com dados e informações mais atualizadas. As análises pontuais serão apresentadas quando forem pertinentes à argumentação da tese. A obra de Mendonça figura entre as primeiras a trazerem à tona este tema e é leitura obrigatória para quem tratará da influência das línguas africanas no $\mathrm{PB}$, contudo, não se deve esquecer que o autor era um homem de seu tempo, o que implica a visão de mundo da época em que a obra foi escrita, a bibliografia disponível à época e os estudos realizados até então.
} 
ao vocabulário apresentado por ela nessa obra. A autora identifica cinco níveis de contexto de utilização desses vocábulos: o nível 1 corresponde à linguagem religiosa dos candomblés da Bahia, ou língua de santo; o nível 2 corresponde à linguagem usual do povo de santo; o nível 3 representa a linguagem popular da Bahia; já o nível 4 é o que se refere à linguagem corrente, familiar na Bahia e, por fim, o nível 5 corresponde ao português do Brasil em geral.

Antes de apresentar o vocabulário, Castro (2001), nos mesmos moldes de Mendonça (1933), passa pela classificação das línguas africanas, pelos ciclos do tráfico de africanos trazidos para o Brasil e pelas possíveis origens das línguas africanas transplantadas. Também não desconsidera a participação indígena na formação do português brasileiro, nas palavras da autora:

[...] as diferenças que separam o português falado no Brasil e em Portugal são, a priori, o resultado de um longo, progressivo e ininterrupto movimento explícito de aportuguesamento dos africanismos e, em sentido inverso, de africanização do português sobre uma base indígena preexistente no Brasil. Por sua vez, sustentada em fatores favoráveis de natureza extralinguística (prestígio social, poder econômico, escolaridade, etc.) [...] (Castro, 2001: 118)

Ainda no domínio lexical, Alkmin \& Petter (2008) apresentam um estudo sobre vocábulos de origem africana em uso no PB, observando a historicidade dessas palavras por meio de registros de estudiosos dos séculos XIX e XX, analisando a estabilidade e o dinamismo desses vocábulos. O corpus utilizado pelas autoras foi constituído a partir do vocabulário apresentado por Castro (2001), retirando os vocábulos de níveis 1 e 2, o que resultou um total de 400 termos. Após a verificação desses vocábulos com informantes naturais de Salvador (BA), Rio de Janeiro (RJ), São Paulo (SP) e Campinas (SP), as autoras compilaram um total de 249 vocábulos que foram submetidos novamente a análises de falantes nativos do $\mathrm{PB}$, desta vez oriundos de regiões mais variadas, a saber, Macapá (AM), Rio de Janeiro (RJ), São Paulo (SP), Salvador (BA), Vitória da Conquista (BA) e Barreiras (BA).

No final da análise e após a exclusão de termos referentes a regionalismos evidentes, religião, música, comidas reconhecidamente de origem africana, e palavras chulas, Alkmin \& Petter (2008) chegaram a um total de 56 vocábulos comuns ao universo dos informantes pesquisados. Este total foi organizado em três categorias: a primeira delas, com 30 vocábulos, inclui termos utilizados em qualquer interação social, como, por exemplo, 
abadá, caçula, marimbondo, quilombo, cochilar, entre outros; a segunda categoria, com 9 vocábulos, é integrada por termos informais, de uso coloquial como cafuné, muxoxo, catinga, banguela, bamba, entre outros, e a terceira categoria, com 17 vocábulos, é formada por termos marcadamente informais, de uso restrito como muvuca, zumbi, cafundó, babaca, cafofo, cambada, entre outros.

Quanto à historicidade desses termos, os vocábulos da categoria 1 são encontrados já nos primeiros trabalhos do século XIX e seus significados se mantêm estáveis, equivalentes aos utilizados nos dias de hoje. Sobre a categoria 2, alguns dos termos também são atestados em obras do século XIX, contudo, aparecem alguns vocábulos como catimba, por exemplo, de uso mais recente, não encontrados em nenhum dos trabalhos consultados do século XX. Já em relação à categoria 3, ao que parece, alguns termos tiveram uso no século XIX, não sendo encontrados em obras do século XX, mas retornando posteriormente, sendo utilizados nos dias de hoje, como é o caso de biboca, cafofo, quizumba e sacana, por exemplo. As autoras observam que esta categoria teria o maior dinamismo, considerando o fato ainda de serem os vocábulos de uso mais informal e restrito.

Importante ainda observar, a respeito do trabalho de Alkmin \& Petter (2008), que a grande maioria dos vocábulos presente no estudo das autoras é de origem banta, o que comprova a grande participação das línguas desse grupo na formação do $\mathrm{PB}^{12}$.

Em termos morfológicos, a flexão verbal reduzida, ausência de concordância sujeito-verbo, marca de número no primeiro termo do sintagma nominal, emprego do pronome objeto e referência definido/indefinido são alguns dos fenômenos explorados.

Entre as características morfológicas estudadas para atestar a participação das línguas africanas no PB está o preenchimento do sujeito pronominal, o que faria com que o português estivesse perdendo a propriedade de ser uma língua de sujeito nulo. Esta necessidade de preenchimento do sujeito pronominal estaria ligada diretamente ao enfraquecimento do paradigma da flexão de número e pessoa do verbo. $\mathrm{O}$ enfraquecimento do paradigma verbal é utilizado ora para explicar uma possível crioulização do PB (Holm, 1992) ou uma reestruturação parcial (Holm, 2004, 2011), ora para explicar uma transmissão linguística irregular (Lucchesi, 2009c), contudo, em todos os casos, esta característica está associada ao contato do português com

\footnotetext{
${ }^{12}$ Há ainda outros trabalhos que tratam do léxico para falar da presença das línguas africanas no PB, entre eles cito Vogt \& Fry (1996), Queiroz (1998), Petter $(1999,2002)$, Bonvini $(2002,2008 b)$, entre outros.
} 
as línguas africanas durante o período colonial. No entanto, nenhum dos estudos aprofunda ou explicita de que forma se deu essa influência.

Outro aspecto do PB que é bastante discutido quando se fala de participação das línguas africanas em sua formação é a marcação de número no sintagma nominal, em especial a marcação de número plural apenas no primeiro elemento do sintagma ${ }^{13}$. Este traço característico do português brasileiro é atribuído especialmente às línguas bantas, em particular às classes nominais dessas línguas. Nas línguas bantas, a informação gramatical de número é veiculada por meio de prefixo como, por exemplo, em quimbundo, o nome pessoa no singular é mú-tù e no plural é á-tù (Gomes \& Okoudowa, 2015), logo, de acordo com os diferentes estudos sobre o tema, no português falado no Brasil, devido ao contato com as línguas bantas, bastaria apenas a presença da informação gramatical de plural no primeiro elemento para que todo o sintagma fosse interpretado como plural ${ }^{14}$.

Na sintaxe, estão entre as características estudadas a marca pré-verbal, a predicação não verbal, dupla negação, focalização do predicado, equivalência reflexivo/passivo, redobro, ter e estar, falar $p a$, preposições $n i, n a$, entre outros (Bonvini, 2008a). Entre os estudos no âmbito da sintaxe, merecem destaque as análises que têm sido desenvolvidas por Negrão e Viotti a respeito das estratégias de impessoalização.

Negrão \& Viotti $(2008,2010,2011,2014)$ defendem a hipótese de que as construções de impessoalização do português brasileiro surgiram a partir do contato entre o português clássico e o quimbundo. Essas construções são entendidas como

construções em que a figura do agente perde sua força, quer porque apareça em uma posição periférica, como no caso da passiva prototípica; quer porque seja um agente indeterminado, genérico, ou indefinido, como nas construções tradicionalmente conhecidas como passiva sintética ou construções de sujeito indeterminado (Negrão \& Viotti, 2014: 304) ${ }^{15}$.

Importante sublinhar o fato de que no quimbundo não há as passivas prototípicas, mas sim construções consideradas como

\footnotetext{
${ }^{13}$ Mais detalhes dos estudos sobre a marcação de número no sintagma nominal foram apresentados no capítulo 2, em 2.1.1.1.

${ }^{14}$ Dos diversos trabalhos que abordaram este tema para falar da participação das línguas africanas na formação do PB é possível citar Guy (1981), Holm (1992), Baxter (2009), Oliveira et al. (2009), entre outros.

${ }^{15}$ Para mais detalhes sobre a análise, bem como sobre a noção de impessoalização, ver os trabalhos já citados das autoras.
} 
parte do epifenômeno 'passiva', advindas da confluência de estruturas de deslocamento à esquerda, e de estruturas de indeterminação do sujeito marcadas pela morfologia da $3^{a}$ pessoa do plural no verbo na forma ativa (Negrão \& Viotti, 2014:310).

As construções de impessoalização estudadas no PB pelas autoras também são consideradas parte desse epifenômeno passiva, que estão distantes das passivas prototípicas do português, conforme exemplos apresentados a seguir:

(1) A cada um minuto quatro coisas vendem.

(2) A entrevista tá gravando.

(Negrão \& Viotti, 2014:316-7)

Construções como as apresentadas em (1) e (2), analisadas como impessoalização total, nas quais o argumento tema/paciente é promovido, são chamadas de construções absolutas e tidas como resultante do contato entre o português clássico e o quimbundo. Os traços do português clássico que fizeram parte do banco de traços do qual se originaram essas construções absolutas foram:

- (i) a posição pré-verbal da sentença não é a posição canônica para sujeitos, sendo frequentemente ocupada por argumentos tema/paciente por razões pragmáticas;

- (ii) argumentos agente, sujeitos da sentença desencadeadores de concordância no verbo, frequentemente são nulos ou se realizam em posição pós-verbal;

- (iii) sujeitos nulos recebem interpretação referencial definida se estiverem anaforicamente ligados a constituintes já inseridos no discurso;

- (iv) nas construções com se, o argumento tema/paciente, quando fronteado, ocupa a posição pré-verbal destinada a constituintes nãosujeito e o argumento agente recebe interpretação definida genérica.

Já os traços do quimbundo que também constituíram o banco de traços foram:

- (i) a posição pré-verbal da sentença é ocupada por argumentos tema/paciente fronteados;

- (ii) o argumento tema/paciente fronteado é retomado pelo prefixo de objeto, adjacente ao verbo; e 
- (iii) o prefixo de sujeito, afixado ao verbo em sua forma ativa, carregando marcas de $3^{a}$ pessoa do plural, causa ambiguidade entre duas interpretações possíveis para o argumento sujeito: a intepretação referencial definida pelo estabelecimento da relação anafórica com algum constituinte já introduzido no discurso, ou uma interpretação genérica/indefinida.

O que teria ocorrido no PB é a congruência dos traços do português clássico e do quimbundo, o que teria gerado as construções absolutas com argumento tema/ paciente deslocado para a posição pré-verbal, e o verbo na voz ativa. A leitura impessoal, oriunda do quimbundo, gera a total ausência de agentividade.

As autoras ainda explicam, com base nessa mesma linha de raciocínio, as construções de impessoalização parcial do português, bem como as 'passivas curiosas' do português angolano. Não é meu intuito aqui apresentar todo o trabalho desenvolvido pelas autoras, mas sim chamar a atenção para a importância desse trabalho dentro dos estudos que buscam explicar o português brasileiro através do contato de línguas, em especial com as línguas africanas. Esta importância, entre outras razões, reside principalmente em dois pontos: o primeiro deles é o fato de ser uma análise na área da sintaxe que avança em muito os estudos já realizados até então, os quais residiam, como já apontados anteriormente, no estudo das marcas pré-verbais, da predicação não verbal, da dupla negação, entre outras características.

A segunda razão é a explicação oferecida em termos de congruência de traços, que mostra que a participação das línguas africanas na formação do PB não reside apenas nos traços característicos da língua A ou da língua $B$, mas sim que, por meio do contato, pode surgir uma característica distinta daquelas disponíveis no banco de traços de uma dada ecologia de contato linguístico. Estes fatos ampliam ainda mais o leque de possibilidades dentro dos estudos que buscam explicar a participação das línguas africanas na formação do PB e oferecem um direcionamento de análise que até então não tinha sido explorado.

\subsection{Considerações do capítulo}

Neste capítulo foi apresentada a teoria de contato linguístico (Mufwene, 2001, 2008) a partir da qual serão analisados os dados das comunidades quilombolas alcantarenses. Dentro dessa perspectiva, para melhor se compreender a formação do português brasileiro, é preciso uma profunda 
investigação da história da colonização e das relações socioeconômicas subjacentes às interações entre os membros da população colonial.

Já em termos linguísticos, a tarefa é verificar os traços linguísticos das variedades em competição nesse ambiente, voltando-se para as propriedades gramaticais das línguas que participaram da formação do português brasileiro, analisando não só os traços das línguas participantes, mas também a possível congruência entre os traços das línguas em contato. Para entender as situações de contato das quais emergiram as línguas coloniais, ou mesmo as ditas línguas crioulas, no entanto, é possível trabalhar com noções mais amplas, como por exemplo traços comuns de famílias de línguas, ou com características areais (Negrão \& Viotti, 2014:302-3), não necessariamente com características $\mathrm{X}$ ou $\mathrm{Y}$.

Ou seja, para entender e analisar a formação do português brasileiro, deve-se iniciar com uma profunda investigação da história da colonização e das relações econômicas subjacentes às interações entre a população da época. E, concomitantemente, estudar as propriedades gramaticais das línguas em contato para delas extrair os possíveis traços em competição que integram o banco de traços.

É preciso lembrar sempre que os resultados obtidos sobre a formação das línguas, e de certas características do português analisadas dentro dessa perspectiva de contato, são hipotéticos. Por mais meticulosa que seja a reconstituição dos fatos, não será possível reconstituir com exatidão a ecologia de contato existente entre o português, as línguas africanas e as línguas indígenas na época colonial (Negrão \& Viotti, 2014; Raso et al., 2011).

Pode-se observar também que, apesar da imprecisão das informações sobre as origens dos africanos vindos para o Brasil em condição de escravos, tanto em termos numéricos quanto em relação à origem exata deles, é possível traçar os principais lugares dos quais esses africanos vieram, África Ocidental e Centro Ocidental, especialmente da região Angola-Congo. A partir dessa informação percebe-se que grande parte das línguas transplantadas para o Brasil era do tronco nigero-congolês, as línguas dos troncos afro-asiático e do tronco nilo-saariano eram em menor número. Logo, as características relevantes para o entendimento da formação do PB seriam as das línguas do primeiro tronco, dado o fato de serem em maior número e, provavelmente, terem contribuído com a maior quantidade de traços.

Em relação ao contexto histórico, foi possível notar que a questão de separar os africanos de diferentes etnias para evitar rebeliões dava-se mais por parte dos fazendeiros do que dos traficantes, pois estes, muitas vezes, não tinham como escolher ou separá-los por etnia pelo fato de dependerem da 'disponibilidade' da oferta. 
Observou-se, ainda, uma ampla participação dos africanos em diferentes áreas da sociedade colonial, contudo, mesmo inseridos em diferentes contextos, a relação entre europeus e africanos escravizados era sempre permeada de violência intensa, tanto física quanto psicológica.

Foi possível verificar que a conhecida expectativa de vida de sete anos dos africanos não era de todo verdade. Estudos apontam para uma expectativa de vida, dos africanos trazidos para o Brasil, de quinze a vinte anos.

Diante do contexto histórico colonial brasileiro, é difícil negar a participação dos africanos na formação do português falado hoje no Brasil, não só por estarem em maior número, mas também por estarem presentes em diferentes setores da sociedade - sempre colocados em posição inferior, é claro. Pode-se dizer que os africanos trazidos para o Brasil na condição de escravos e aprendendo o português como segunda língua foram os grandes responsáveis pela difusão do português pelo Brasil, levando em conta a intensa migração interna impulsionada pelos diferentes ciclos econômicos brasileiros.

Mesmo com essa inegável participação, ainda parece não ser uma tarefa óbvia apontar exatamente de que forma as línguas maternas dos africanos aqui presentes no período colonial interferiram no PB. Vários são os estudos sobre a participação das línguas africanas na formação do português falado no Brasil, com início no começo do século XX, e abarcam diversas áreas da Linguística, como léxico, fonologia, morfologia e sintaxe.

Estudos recentes mostram análises mais elaboradas sobre essa questão, a exemplo de Negrão \& Viotti (2008, 2010, 2011, 2012, 2014), que apontam para um novo direcionamento nas pesquisas que buscam entender o português brasileiro a partir do contato com as línguas africanas. No entanto, essa é uma questão que parece estar longe de ser esgotada, pois os diferentes estudos realizados vêm apontando para novos caminhos de análise, evidenciando as diferentes e complexas formas de participação das línguas africanas na formação do português do Brasil. 


\section{Capítulo 4}

\section{Alcântara e a ecologia maranhense}

Neste capítulo apresento a ecologia do Maranhão na época colonial e imperial, a fim de traçar os elementos constitutivos daquela sociedade e como se dava a interação entre eles, além de identificar o papel de cada setor na sociedade. Exploro igualmente a história da formação dos quilombos maranhenses e como era a relação dos aquilombados com a sociedade externa, e também a participação dos negros e quilombolas na sociedade como um todo e em rebeliões como a Balaiada.

Discorro sobre a história de formação de Alcântara e dos quilombos deste município, com o intuito de entender o contato linguístico que originou determinadas características das falas das comunidades alcantarenses estudadas.

Por fim, serão apresentadas as comunidades de Mamuna e Itamatatiua, sua organização, estrutura, atividades comerciais, história de formação entre outras informações relevantes para o entendimento delas.

\subsection{A ecologia maranhense}

O estado do Maranhão, localizado no Nordeste brasileiro, cuja capital é a cidade de São Luís, possui hoje uma população de aproximadamente 6 milhões e 900 mil pessoas. Relatos afirmam que, antes da chegada dos portugueses, o estado era habitado pelos povos das famílias etnolinguísticas tupi e jê. Os primeiros residiam no litoral e os jês, no interior. 


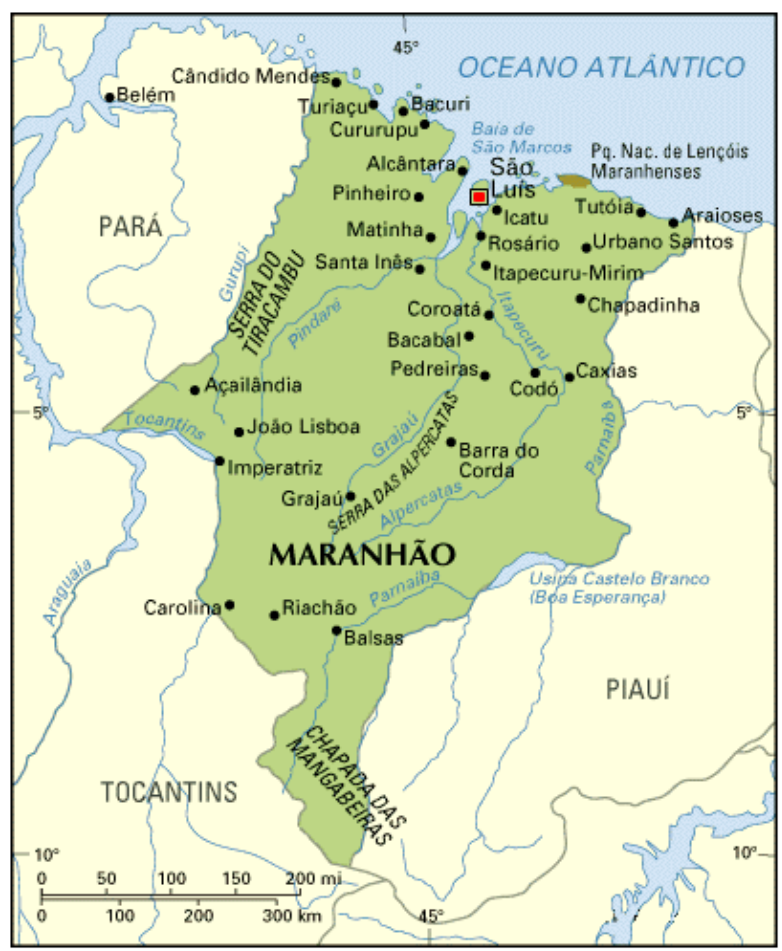

Figura 4.1: Mapa político do Maranhão. Fonte: postocastelo.com.br

O Estado do Maranhão e Grão-Pará, instituído como unidade administrativa pela Coroa Portuguesa em 1621, era ligado diretamente a Lisboa, separado do Brasil. Até meados do século XVIII englobava as áreas que correspondem à Amazônia brasileira, ao Ceará e ao Piauí. Após a segunda metade do século XVIII as áreas do Grão-Pará e Maranhão seriam separadas (Gomes, 2005: 132) ${ }^{1}$. Somente durante o século XIX é que o estado ganhou a configuração geográfica que possui hoje.

Autores apontam que havia no Maranhão, no século XVII, aproximadamente 23 aldeias tupinambás. No início desse século, de modo mais preciso, em 1618 e 1619, o Maranhão já recebe navios com portugueses vindos de Açores a fim de colonizar o local — nesta época chegam em torno de 500 açorianos. Entre 1620 e 1627, a Coroa portuguesa enviou mais 700 açorianos em uma tentativa de impulsionar o desenvolvimento da província (Lima, 1981:58-59; Viveiros, 1954: 15).

Por volta de 1622, foram instalados os primeiros engenhos de açúcar na região de Itapecuru, interior do estado (Santos, 1983: 8; Viveiros, 1954: 17).

\footnotetext{
${ }^{1}$ Nesse sentido, o Estado do Maranhão mencionado no decorrer do capítulo refere-se a essa unidade administrativa e não ao estado do Maranhão - grafado com letra minúscula - que corresponde aos limites geográficos atuais.
} 
A situação da população do Estado do Maranhão em meados do século XVII era de miséria:

todos andavam descalços, os escravos nus, nas cidades e nas fazendas, as pessoas mais importantes com vestes de panos de algodão tinturadas de preto. Em 61, famílias nobres deixaram de ir à missa, no Natal, por não terem as moças o que vestir. (Lima, 1981: 74)

Entre os anos de 1621 e 1684 a vida econômica do Estado do Maranhão era instável e precária. No princípio havia o tráfico de índios, uma pequena exportação de algodão e alguns produtos da terra, sempre baseada no trabalho servil do índio.

Em 1682 criou-se a Companhia de Comércio do Maranhão e Grão-Pará, com a concessão de monopólio e o compromisso de trazer até dez mil escravos negros em 20 anos, mínimo de 500 por ano (Lima, 1981: 80; Santos, 1983: 15). Além de importar fazendas e gêneros para abastecer o mercado, melhorar a indústria e a lavoura, e garantir a entrada no porto de, pelo menos, um navio por ano. Todavia, os escravos não vieram, os gêneros eram de má qualidade, os navios eram escassos e a Companhia roubava nos preços, nos pesos e nas medidas.

No final do século XVII, a vida da colônia ainda era difícil. Em 1694 nenhum navio aportou de Lisboa, não havia sal, importado do reino, e as missas deixaram de ser celebradas por falta de hóstias e vinho. O comércio era feito por meio de trocas, não havia dinheiro; o cravo, principal produto de então, entrou em decadência. A população estava abaixo de $10 \mathrm{mil} \mathrm{e,}$ para completar esse cenário, uma nova e violenta epidemia de varíola se estendeu por todo o Estado, vitimando mais de 200 pessoas, deixando a cidade com o cheiro dos mortos que, de tão grande o número, as pessoas não davam conta de enterrar.

Em 1721 houve uma nova tentativa de introduzir africanos escravizados no estado e só em 1732 começou a circular no Maranhão o dinheiro em forma de moedas de ouro, prata e cobre. Em 1753 há uma nova mudança de nome e o Maranhão passa a se chamar Grão-Pará e Maranhão, com capital em Belém, compreendendo as capitanias de São José do Rio Negro, Grão-Pará, Maranhão e Piauí. Em 1772, divide-se novamente em Grão-Pará, com Rio Negro e Maranhão, com Piauí.

Segundo Bernardo Pereira de Berredo, que governou o estado entre 1718 e 1722, além da capital São Luís, só existiam na capitania as vilas de Alcântara e Icatu, ambas no continente, em frente à ilha de São Luís, e pequenas povoações, engenhos e fazendas em locais não muito afastados do litoral como Itapecuru, Mearim, Pindaré e Munim (Faria, 2012:53). 
Apesar do escasso número de africanos na região desde o início da colonização, entre os anos de 1756 e 1788 foram introduzidos cerca de 28.500 africanos no Maranhão e Grão-Pará. Destes, pouco mais de 12.000 ficaram na região do Maranhão, os demais foram levados para a região do Pará. Entre 1779 e 1790 a média anual de africanos escravizados trazidos para o Maranhão era de 1605 e de 547 para o Grão-Pará (Gomes, 1997: 43;45).

A criação da segunda Companhia de Comércio, em 1755, agora Companhia Geral do Grão-Pará e Maranhão, trouxe certa prosperidade ao estado. Em vinte anos de serviço possibilitou a construção de navios, muitos deles utilizados para o tráfico negreiro, e promoveu a cultura de arroz e de algodão em grande escala. Faria (2012: 48) observa que parece ser consenso entre os estudiosos do Maranhão que a criação da segunda Companhia de Comércio do Grão-Pará e Maranhão, maior símbolo da política de Pombal, seria o "marco zero" da história econômica do estado.

O Maranhão viveu seu apogeu econômico de meados do século XVIII até 1894. Estes sinais de riquezas são decorrências do início e da expansão de um sistema agroexportador, parte da política de incentivo da agricultura colonial desenvolvida por D. José I e por seu ministro, o Marquês de Pombal (Faria, 2012:39).

Este apogeu divide-se em dois momentos: o Ciclo do Algodão, até 1868, e o Ciclo do Açúcar, de 1868 a 1894. Em 1870, o estado contava com aproximadamente 500 engenhos de açúcar. As exportações cresceram até a metade da década de 1880, declinando de forma abrupta após a abolição da escravatura, em 1888, e cessando nos primeiros anos do século seguinte (Faria, 2012: 45).

Apesar dessa ideologia da decadência, termo cunhado por Alfredo Wagner para explicar a postura de alguns autores que sustentam a hipótese de que $o$ Maranhão entrou em decadência após a Abolição, outros estudiosos, como o próprio Almeida $(2006$ b,c) e Faria (2012), contestam essa decadência tão advogada por alguns. O fim do escravismo ocasionou a decadência da agroexportação no Maranhão, no entanto, a pequena produção baseada no trabalho familiar expandiu-se, passando a ser o padrão de produção, não limitada apenas à subsistência, mas sim vinculada ao mercado. A economia do estado assentou-se, após 1888, em outras bases.

Na primeira metade do século XIX, o Maranhão tinha duas bases econômicas, uma fundamentada na pecuária extensiva e a outra, na agricultura de exportação. Como consequência dessa prosperidade, formaram-se vilas, instituições, houve a miscigenação dos povos, criaram-se novas relações de produção e intensificou-se a imigração europeia do reino, especialmente dos Açores (Santos, 1983: 7; Lima, 1981: 105). 
No início século XIX, em 1804, a população escrava do Maranhão era de mais de 37.600 e o total do estado era de 74.100; em 1819 esse número saltou para mais de 133.300, de um total de 200.000. Entre 1811 e 1820 foram importados cerca de 36 mil africanos para o Maranhão. Em 1819, a população escrava alcançou o índice de $66,6 \%$ em relação ao total da população (Luna \& Klein, 2010: 192; Gomes, 2005: 133). Precisar exatamente a origem desses africanos seja, talvez, impossível, no entanto, há algumas pistas que podem indicar uma direção. Negros minas, grupo que inclui as áreas sudanesas, foram introduzidos no Pará e Maranhão e chegaram de Bissau, capital da Guiné portuguesa, em 1753.

Notícias sobre a introdução de africanos vindos de Angola, região banta, datam de 1759. Nesse ano chegou o navio Nossa Senhora da Conceição com 500 negros da nação Moxicongo, dos quais 132 morreram na viagem e os 338 restantes chegaram com febre e muito magros. Sabe-se que os africanos vinham dos portos de Bissau, Cacheu, Angola e Guiné e dos entrepostos de Cabo Verde e Serra Leoa (Salles, 1971: 56; Lima, 1981: 115; Assunção, 2010).

No século XIX, a cidade de São Luís tinha por volta de 152.890 habitantes. Entre os brancos encontravam-se portugueses, vindos das ilhas de Açores e de outras partes da Europa, a grande maioria casada com as filhas do país. A predominância da população escrava era incontestável nessa época, chegando à proporção de dois para um. Esse número pode ser ainda maior, considerando o fato de que muitos escravos não eram computados pelas autoridades civis e eclesiásticas (Prazeres [Maranhão], 1891; Lima, 1981).

Faria (2012: 63) chama atenção para o fato de que a falta de certeza, bem como o desencontro dos dados populacionais, é reflexo da precariedade dos levantamentos estatísticos da época da Colônia e do Império. Os recenseamentos regulares só começaram a ser feitos a partir da política mercantilista pombalina, apesar de esses levantamentos não serem realizados em todas as províncias. 


\begin{tabular}{|l|c|c|r|}
\hline & Homens & Mulheres & Total \\
\hline \hline LIVRES & & & $\mathbf{6 8 . 5 5 9}$ \\
Brancos & 12.647 & 11.347 & 23.994 \\
Índios & 5.118 & 4.569 & 9.687 \\
Mulatos & 13.419 & 11.874 & 25.111 \\
Eclesiásticos & - & - & 259 \\
ESCRAVIZADOS & & & $\mathbf{8 4 . 5 3 4}$ \\
Mulatos & 3.706 & 2.874 & 6.580 \\
Pretos & 42.980 & 34.974 & 77.954 \\
\hline \hline TOTAL & & & $\mathbf{1 5 2 . 8 9 3}$ \\
\hline
\end{tabular}

Tabela 4.1: População Livre e Escrava no Maranhão - 1821. Fonte: Lago (1822) em Faria (2012: 63).

Após essa época, houve um declínio da população escrava, consequência da proibição do tráfico, em 1850, e do aumento da população livre. Em 1853 teve início a imigração estrangeira para o Maranhão, especialmente a europeia (Gomes, 2005: 274)

\begin{tabular}{|l|c|c|c|c|c|}
\hline ANO & LIVRES & $\%$ & ESCRAVIZADOS & $\%$ & TOTAL \\
\hline \hline 1798 & 42.244 & $(53,5 \%)$ & 36.616 & $(46,5 \%)$ & 78.860 \\
1821 & 68.359 & $(44,7 \%)$ & 84.534 & $(55,3 \%)$ & 152.892 \\
1841 & 105.147 & $(48,7 \%)$ & 111.905 & $(51,6 \%)$ & 217.054 \\
1861 & 227.873 & $(72,5 \%)$ & 84.755 & $(27,5 \%)$ & 312.628 \\
1872 & 284.101 & $(69,2 \%)$ & 74.939 & $(20,8 \%)$ & 359.048 \\
\hline
\end{tabular}

Tabela 4.2: População do Maranhão 1798 - 1872. Fonte: Faria (2012: 65, adaptada) e Gomes (2005: 133, adaptada).

Em 1872, 78\% da população do Maranhão era livre, em números absolutos são 263.080 pessoas, no entanto, desse total, apenas 80.902 eram considerados "brancos"(Gomes, 2005: 133).

Em termos gerais, na primeira metade do século XIX, a sociedade maranhense poderia ser entendida a partir de três critérios. $O$ primeiro critério era o da "cor" que traduzia uma hierarquia social baseada na "dimensão ideológica" e estava dividida da seguinte forma: no topo da pirâmide encontravam-se os brancos (portugueses e brasileiros); na faixa intermediária estavam os mestiços (cafuzos, mulatos e outros); e na base, que era extensa, encontravam-se os pretos $^{2}$.

\footnotetext{
${ }^{2}$ Importante salientar o fato de que os autores mencionam a população indígena apenas brevemente na constituição dessa pirâmide, quando consideram o critério jurídico.
} 
O segundo critério com base no qual é possível entender a sociedade maranhense é o econômico, determinado pela situação dos indivíduos na produção. No topo dessa pirâmide estariam os grandes fazendeiros e os comerciantes; na faixa do meio um grupo bem diversificado e hierarquizado entre si: pequenos fazendeiros, artesãos e soldados, além de uma "elite" dentro da própria massa escrava, composta por negros de ganho, escravos artesãos, feitores, entre outros; e na base dessa pirâmide estão os escravos de eito. $\mathrm{O}$ critério econômico, no entanto, reproduzia o critério de cor.

O último critério está assentado em uma "dimensão jurídica" e teria quatro camadas: a primeira camada composta de indivíduos livres, proprietários de escravos, a segunda camada de pessoas livres sem escravos, a terceira de forros e índios "domesticados" e a quarta de escravos (Faria, 2012: 85; Assunção, 1996) ${ }^{3}$. Ou seja, os critérios de cor, econômico e jurídico acabavam dividindo a população da mesma forma, pois os homens livres, proprietários de escravizados, eram os grandes fazendeiros e comerciantes brancos, e a base, composta por pessoas escravizadas, era negra. A parte intermediária dessa pirâmide era composta pela camada da população mestiça, forros, pequenos fazendeiros, entre outros.

A vida dos africanos no Maranhão não era muito diferente da vida dos africanos do restante do país. A alimentação era à base de arroz e mandioca, de vez em quando uma posta de carne. De dois em dois anos recebiam peças novas de roupa, um calção grosso ou saia. Moravam em senzalas e a carga horária de trabalho diária era de quinze horas ou mais.

No que concerne ao trato dos escravizados, no entanto, o estado possuía uma péssima reputação, sendo que o envio para o Maranhão era muitas vezes usado como ameaça aos cativos de outras regiões. Não há uma explicação exata sobre o motivo dessa má reputação, contudo, as péssimas condições de trabalho e a proliferação de doenças endêmicas como a malária contribuíram bastante (Assunção, 2010).

Em relação à sociedade maranhense, a oposição entre o grupo reinol e o nacional era patente: os brasileiros desfrutavam dos benefícios da posse de terra e da sua produção e os portugueses exerciam exclusividade sobre o comércio externo (Santos, 1983: 55). Havia também a presença de escravos nos trabalhos artesanais, em que conviviam com homens livres assalariados, o que deu possibilidades, embora restritas, de ascensão social e o despertar de novas expectativas.

\footnotetext{
${ }^{3}$ Após a segunda metade do século XIX a população maranhense se tornou mais complexa, com várias nuances, porém, essa divisão se reflete ainda hoje na sociedade maranhense e mesmo no Brasil como um todo, com uma pequena parcela da população branca detentora de grandes capitais e a população negra, em geral, compondo a camada pobre da sociedade.
} 


\begin{tabular}{|l|c|c|}
\hline Profissões & Livres & Escravos \\
\hline \hline Alfaiates & $61(38,8 \%)$ & $96(61,2 \%)$ \\
\hline Caldeireiros & $04(80,0 \%)$ & $01(20,0 \%)$ \\
\hline Carpinteiros & $178(35,3 \%)$ & $326(64,7 \%)$ \\
\hline Entalhadores & $96(69,5 \%)$ & $42(30,5 \%)$ \\
\hline Carpinteiros navais & $80(67,7 \%)$ & $38(32,3 \%)$ \\
\hline Serralheiros & $05(100,0 \%)$ & $0(0,0 \%)$ \\
\hline Ferreiros (em São Luís) & $37(61,6 \%)$ & $23(38,4 \%)$ \\
\hline Tanoeiros (em São Luís) & $02(66,6 \%)$ & $01(33,4 \%)$ \\
\hline Marceneiros & $30(52,6 \%)$ & $27(47,4 \%)$ \\
\hline Ourives & $49(81,6 \%)$ & $11(18,4 \%)$ \\
\hline Pedreiros e britadores & $404(40,0 \%)$ & $608(60,0 \%)$ \\
\hline Pintores e ceriadores & $10(66,6 \%)$ & $05(33,4 \%)$ \\
\hline Corrieiros & $04(80,0 \%)$ & $01(20,0 \%)$ \\
\hline Curtidores & $04(40,0 \%)$ & $06(60,0 \%)$ \\
\hline \hline Total & $964(44,9 \%)$ & $1.185(55,1 \%)$ \\
\hline \hline Escravos na indústria & & 1.800 \\
\hline
\end{tabular}

Tabela 4.3: Porcentagem de trabalhadores livres e escravizados nas diferentes profissões. Fonte: Santos (1983)

Em relação à população indígena do estado, esta dividia-se basicamente em dois grupos: o grupo tupi, que contemplava as tribos tupinambás, tabajaras, caetés, além de outras, e o grupo tapuia, com as tribos guajas, guajajaras, gamelas, barbados entre outras, povoando os vales dos rios Itapecuru, Pindaré, Grajaú, Mearem e Munim (Lima, 1981: 23).

Os índios possuíam uma organização socioeconômica, praticavam a lavoura, tinham animais domésticos e criavam galinhas. Ao serem perseguidos pelos portugueses, reagiam lutando ou fugindo e, para escapar à escravidão, mudavam-se constantemente.

Após a derrota e consequente expulsão dos franceses do Maranhão, os tupinambás ficaram à mercê dos portugueses. O contato entre eles teve consequências letais para os tupinambás. Na Ilha de São Luís existiam 27 grupos locais importantes, com um total de 12 mil indivíduos, na época da conquista portuguesa (Fernandes, 1963: 49). Ao todo, contando os de fora da Ilha, existiam 35 mil indivíduos.

Os índios foram escravizados desde o início da colonização do Maranhão. Todos os serviços ficavam a cargo do índio. De acordo com Viveiros (1954: 27), não houve morador de São Luís, desde o Capitão General Governador até o mais humilde colono, que não utilizasse a força de trabalho 
indígena. Esta população foi muito afetada pelo contato com os portugueses, em especial pelas doenças trazidas por estes últimos. Duas grandes epidemias contribuíram para aumentar a taxa de mortandade dos indígenas: a primeira ocorreu em 1662 e vitimou aproximadamente 2 mil pessoas e a segunda ocorreu em 1695.

Em resumo, os tupinambás do Maranhão e do Pará que não foram exterminados nas guerras contra os portugueses afastaram-se para o litoral e os que ficaram entre os brancos foram aldeados ou tornaram-se cativos, trabalhando para seus senhores. No final do século XVII e início do XVIII havia apenas três aldeias exclusivamente com índios tupinambás, situadas na Ilha de São Luís, em Tapuitapera e na Ilha do Sol. Alguns estavam espalhados em outras aldeias, convivendo com índios de outros grupos; uma outra parte estava espalhada nas casas e fazendas dos colonos (Fernandes, 1963:54).

Sobre a situação dos índios no Maranhão, Lima diz que

[a]través dos dois primeiros séculos de contato com os europeus, estes índios encontraram guarida e alguma proteção contra os colonos nas missões religiosas, principalmente jesuíticas. Com a expulsão dos jesuítas, em 1759, a administração das aldeias foi entregue a sacerdotes menos interessados na obra catequética e posteriormente a oficiais civis. Mais tarde, os índios foram declarados cidadãos livres e suas aldeias promovidas a vilas, recebendo nomes portugueses, pelourinhos e outras prerrogativas. Esta farsa libertária só representou para os índios o direito de serem explorados sem ter para quem apelar. Os administradores da vila foram recrutados, em geral, entre vizinhos que cobiçavam as terras da antiga missão ou a seara representada pelo controle da força de trabalho de todos os índios aldeados (Lima, 1981:34).

O convívio dos índios com a população sertaneja que cresceu junto com o desenvolvimento do estado era permeado de conflitos. Os sertanejos submetiam os índios de tal maneira que estes se viram obrigados a abandonar suas antigas aldeias, havia muita hostilidade e conflitos por posse de terras.

No século XIX, foram realizadas muitas entradas ${ }^{4}$, pois os indígenas eram vistos como uma ameça ao crescimento das fronteiras das plantações em direção às terras virgens. Por meio dos registros dessas entradas é possível identificar alguns povos indígenas que entravam em choque com

\footnotetext{
${ }^{4}$ Expedições particulares ou oficiais que visavam apresar ou transferir de lugar os povos indígenas.
} 
essas expedições. Na ribeira do Itapecuru, de Cantanhede a Codó, eram os gamela; acima de Caxias, na direção de Pastos Bons, os timbira mateiro; nas margens do Grajaú eram os timbira pukobyé. Em relação ao índio, a prioridade daquela época não era integrá-los ao mundo do trabalho, mas sim mantê-los longe e contê-los para que não atrapalhassem o crescimento das fazendas de agricultura e pecuária (Faria, 2012: 118-24).

A colonização do território brasileiro estava intimamente ligada à política de extermínio indígena. Em um período de 32 anos, mais de 2 milhões de índios de 400 aldeias foram extintos. Faria (2012: 217) observa que, dos 200.000 índios estimados para o Maranhão quando da chegada dos primeiros portugueses, apenas 8.000 sobreviventes chegaram no início do século XX.

Sobre a integração de negros e índios, Salles (1971) faz a seguinte observação:

Charles Wagley e Eduardo Galvão[...] [e]ncontraram o negro solidário com o índio nas vicissitudes sociais. Não importa se negro autêntico ou se índio autêntico. O passaporte da autenticidade, naquele contexto, já havia perdido tôda ou quase tôda importância. Ambos despojados dos seus padrões culturais, quebrados definitivamente, amalgamados numa nova cultura, resultante da fusão de três componentes étnicos. O processo de desenvolvimento dessa nova cultura, visto superficialmente, é pouco acelerado. Visto porém em profundidade mostra-se extremamente ativo. Sobretudo no que diz respeito às convergências culturais (Salles, 1971: 67).

Apesar da aparente harmonia, essa relação nem sempre foi de solidariedade. Houve muitos conflitos entre indígenas e escravizados, especialmente quando estes últimos fugiam e formavam quilombos, o que fazia com que os índios se sentissem ameaçados quanto ao território.

Além dos fazendeiros, comerciantes, índios e escravizados, havia a camada da população livre e pobre. Esta parte da população, também segregada, era empregada em tarefas que os escravos não podiam realizar como, por exemplo, reprimir quilombos, vigiar os índios do sertão, agricultar terras longínquas, descobrir novos regatos auríferos, entre outras. Esta camada era marcada pela "mobilidade espacial, heterogeneidade, fluidez, insegurança do cotidiano e pânico perante a Justiça, vivendo em tensão constante, numa situação de conflito latente e violência pulverizada" (Faria, 2012: 134) $)^{5}$.

\footnotetext{
${ }^{5}$ Uma pequena parte dessas pessoas era presa por vadiagem e passava por um processo judicial - havia legislação proibindo a vadiagem desde os tempos coloniais -, caso a
} 
Esses pobres livres eram vistos pela elite maranhense como inúteis e perigosos por estarem fora da grande lavoura, ou participarem dela de forma marginal. Assim como os índios, a preocupação maior era mais em contê-los do que integrá-los de fato ao mundo do trabalho. Ao que parece, as camadas excluídas da sociedade maranhense, índios, negros e pobres livres, quando não em conflito por questões territoriais, estabeleciam uma relação de solidariedade. Estes últimos casavam-se com escravas, relacionavam-se com os escravos fugidos, avisavam-lhes das diligências, entre outras coisas (Faria, 2012: 227) ${ }^{6}$.

\subsection{Quilombos}

Sobre a definição do termo quilombo, a Fundação Cultural Palmares (FCP) afirma:

Consideram-se comunidades remanescentes de quilombos os grupos étnicos raciais, segundo critérios de autoatribuição, com trajetória histórica própria, dotados de relações territoriais específicas, com presunção de ancestralidade negra relacionada com formas de resistência à opressão histórica sofrida. Já o conceito de comunidades negras tradicionais é mais amplo. São grupos culturalmente diferenciados e que se reconhecem como tais, que possuem formas próprias de organização social, que ocupam e usam territórios e recursos naturais como condição para sua reprodução cultural, social, religiosa, ancestral e econômica, utilizando conhecimentos, inovações e práticas gerados e transmitidos pela tradição (Fundação Cultural Palmares, 2010).

Essa definição é importante para entender que nem toda comunidade remanescente de quilombos precisa estar atrelada a um contexto de fuga de escravizados. A questão da autoatribuição será importante, bem como a relação que estes povos têm com a terra. Essa noção é pertinente inclusive para entender a formação de algumas comunidades existentes no Maranhão e, de maneira especial, em Alcântara, que é o foco desta tese.

culpa fosse confirmada, elas eram integradas às tropas de primeira linha. No ano de 1822, por exemplo, apenas uma pessoa conseguiu provar sua inocência e não ser incorporada à tropa (Faria, 2012: 142).

${ }^{6}$ Relevante é o fato de que nas descrições de alguns autores dos séculos XIX e XX não havia diferenças entre as descrições dos livres ociosos e dos índios "civilizados", tomados, muitas vezes, como um grupo só. 
Importante observar que cada território possui sua especificidade e cada grupo étnico deve ser considerado em sua particularidade, segundo o grau de isolamento experimentado, que não é o mesmo para todos, assim como os diversos modos em que foram constituídos (Braga, 2011:51).

O Maranhão é considerado o segundo estado do Brasil em número de negros, pretos e pardos, representando $72,4 \%$ da população, ficando atrás apenas da Bahia, e o maior do país em número de comunidades remanescentes de quilombos (Oosterbeek \& Reis, 2012).

De acordo com os dados oficiais do Ministério do Desenvolvimento Agrário (MDA), obtidos pela sua Assessoria Especial de Gênero, Raça e Etnia (AEGRE), até 2010 foram mapeadas 3.500 comunidades quilombolas no país. No Maranhão há mais de 400 locais identificados como comunidades quilombolas, 337 com processos no INCRA para a titulação da terra, porém, apenas 20 possuem o título. Dessas, somente no município de Alcântara foram identificadas 155, após o surgimento das Certidões de Autodeterminação emitidas pela FCP, com um total de 3.350 famílias, que lhes garantiu direito de acesso a uma série de serviços públicos e, principalmente, aos seus direitos territoriais (Braga, 2011).

O estado do Maranhão pode ser considerado uma sociedade escravista tardia, pois, embora tenha acontecido a introdução de escravos desde o século XVII, foi somente no último quarto do século XVIII que a região apresentou todos os traços de uma escravização agrícola desenvolvida. Havia poucas fazendas escravistas no estado sem quilombos ao seu redor.

Durante todo o período do regime escravista no Brasil, os africanos escaparam e tornaram-se fugitivos. A existência de matas densas ou montanhas inacessíveis a pouca distância do local de fuga era um fator de extrema importância. Logo os quilombos tornaram-se comuns e numerosos em todo o território brasileiro. Nos séculos XVIII e XIX havia diversos quilombos importantes em regiões isoladas.

A origem dessas comunidades é diversa, surgiram da desagregação de grandes fazendas, antes e depois de 1888; das doações de terras para ex-escravizados; da compra de terras pelos escravizados alforriados; da prestação de serviço de escravizados em guerras, como a Balaiada; e da desagregação das fazendas das ordens religiosas, como Carmelitas, Jesuítas e Mercedários.

O surgimento de quilombos no Maranhão data do início do século XVIII. À medida que aumentava o tráfico dos africanos em condição de escravos para o Maranhão e expandiam-se as lavouras de arroz e de algodão, os quilombos multiplicavam-se, aparecendo em Viana, Pinheiro, Alcântara, Itapecuru, no Alto Mearim, em Maracassumé, nas matas de Codó e até em São Luís (Santos, 1983: 67). 
Às vésperas da Independência, o Maranhão apresentava a mais alta porcentagem de africanos do império ( $55 \%$ da população). Por outro lado, não houve imigração europeia significativa, a população branca foi sempre reduzida, 15\% em 1821 (ver tabela 4.1 na seção 4.1). Após a independência, a proliferação de quilombos foi notável e, com a Balaiada, ocorrida entre 1838 e 1841, a fuga e formação de quilombos aumentou ainda mais. Uma numerosa população escrava concentrava-se perto das áreas de fronteira cobertas de mata e o resultado disso foi a multiplicação de quilombos durante o século XIX (Assunção, 1996: 433).

Havia, de acordo com Assunção (1996: 436-7), três tipos de quilombos no Maranhão. O primeiro tipo era formado por pequenos grupos que se escondiam nas matas das imediações das fazendas, localizados em regiões como Alcântara ${ }^{7}$, Viana, Vitória do Mearim, Itapecuru-Mirim, Rosário e Manga do Iguará.

O segundo tipo de quilombo são os grupos mais afastados das imediações das fazendas que conseguiram estabelecer algum tipo de economia de subsistência mais permanente e, eventualmente, combiná-la com a venda de excedentes. Esses quilombos existiram principalmente nas grandes matas das áreas de fronteira.

O terceiro tipo, e último, era o que combinava agricultura de subsistência com garimpo. O garimpo significava maiores recursos para a aquisição de bens e a participação em redes comerciais mais amplas.

Os quilombos existiram não só no Maranhão, mas também em outras partes do Brasil, contudo, quatro fatores contribuíram para a multiplicação desses quilombos ao longo do século XIX no Maranhão, para o número elevado de seus participantes e para a sua longevidade, a saber: (i) a elevada proporção de escravizados em relação à população livre no norte da província, (ii) a existência abundante de matas, com muitos rios e riachos, (iii) a existência de uma fronteira, isto é, de uma vasta zona não controlada pelo Estado, perto das áreas de plantation e (iv) a instabilidade política do período 1820-41 (Assunção, 1996).

Os quilombos conseguiram sobreviver durante décadas no estado, pois viviam em uma complexa rede de comunicação com a sociedade escravista, que lhes fornecia bens materiais e informações sobre as entradas. Eles mantinham também contato permanente com os escravos nas fazendas, chegando, em alguns casos, a trabalhar para fazendeiros. Ainda trocavam ou vendiam produtos de suas roças à população livre. Nesse sentido, os

\footnotetext{
7'É possível perceber, porém, a partir de dados históricos, que boa parte das comunidades formadas em Alcântara surgiram do abandono das terras pelas Ordens Religiosas ou pelos fazendeiros.
} 
quilombos não devem ser vistos como inimigos da sociedade escravista brasileira, mas sim como "um meio de campo que permitia vários tipos de relações" (Assunção, 1996: 460). Além, é claro, do fato de não estarem completamente isolados, mas participarem ativamente da sociedade, com contato constante com as populações fora desses quilombos.

Além desse contato externo, os quilombos também se comunicavam entre si, trocando informações ou planejando ações conjuntas, embora não seja possível avaliar a extensão dessa comunicação devido à falta de dados. A relação desses grupos com os indígenas não era, todavia, sempre pacífica:

Se por um lado algumas fontes sugerem relações pacíficas, não é, por outro lado, de surpreender que, com o avanço da fronteira, grupos indígenas que sentiam a pressão sobre seu território tivessem identificado os quilombolas como seus inimigos. Isso parece ter sido o caso na década de 1870 no Turi/Gurupi, como atestam os problemas dos quilombolas do Limoeiro e do São Sebastião (Assunção, 1996: 460).

Conforme já mencionado, o Maranhão era considerado o pior estado para os escravos. Os negros escravizados de outras províncias eram mandados para lá como punição. A taxa de mortandade era muito alta.

Boa parte dos brancos era de origem portuguesa e a maioria da população livre e pobre era de origem negra ou indígena. Havia ainda a falta de apoio ao Estado imperial, atestada pela recusa dos homens em servir nas suas tropas. Para essa população, a convivência com os quilombos não era algo excepcional. Em alguns casos, homens livres iam se refugiar nos quilombos.

Assunção (1996: 439) atenta para um fato importante que é a ausência de informações sobre essas comunidades. A documentação existente sobre elas era basicamente a feita pelas autoridades, caracterizada por descrições de cunho estratégico, restringindo-se aos aspectos militares, logo, não há informações mais precisas sobre como se dava a organização dessas comunidades, nem como era a vida interna delas.

O que se sabe é que, desde a época colonial e no decorrer do século XIX, no Maranhão, ocorre "a passagem da insubordinação escrava à constituição dos quilombos, a convivência dos quilombolas das matas com os escravos das fazendas e com a população pobre livre, e o ajuste de contas entre escravos e seus senhores" (Assunção, 1996:441). 


\subsubsection{Os quilombolas na Balaiada}

A Balaiada ocorreu entre os anos de 1838 e 1841 e foi a maior guerra civil ocorrida no Maranhão. A guerra da Independência no Maranhão ${ }^{8}$ deu início a um período de instabilidade política que se estenderia até a década de 1840. No decurso de 1822-24, 1831-32 e 1838-40 eclodiram diversas rebeliões, levantes e outros movimentos armados resultantes da disputa pelo poder entre vários grupos da elite. Essas lutas envolveram as camadas livres pobres, o que contribuiu para o acirramento dos conflitos que facilitavam a fuga de escravos e a formação de quilombos.

Os confrontos se davam entre os conservadores (portugueses) e os liberais (brasileiros) e tinham impacto sobre os escravos. A Balaiada ${ }^{9}$ se deu neste cenário de disputa política entre esses dois grupos e como consequência dela, além da crescente revolta da população negra em relação às arbitrariedades da elite. Além disso, o recrutamento em massa dos homens pobres para servir nas tropas do Império em outras províncias causou a revolta da população. A carta do presidente da província para a Comarca de Itapecuru dá uma ideia do cenário na época da revolta:

Constando a esta Presidência por várias representações de Lavradores dessa Comarca que no território da mesma escravos fugidos divagam e cometem mil desordens, roubos e assassinatos, unidos aos criminosos que nos lugares mais desertos buscam amparo contra a vigilância da polícia, cumpre que $\mathrm{V}$. S. faça perseguir, dispersar e apreender semelhante gente, reunindo para este fim, Capitães-do-Mato e pessoas acostumadas a penetrarem nos quilombos, aos quais sustentará, e abonará a cada um duzentos réis por dia [...] (Assunção, 1996: 443).

\section{Caio Prado Júnior observa que}

na origem deste levante, vamos encontrar as mesmas causas que indicamos para as demais insurreições da época: a luta das classes médias, especialmente urbana, contra a política aristocrática e oligárquica das classes abastadas, grandes proprietários

\footnotetext{
${ }^{8}$ Os portugueses da província se recusaram a aceitar o Império, reconhecendo a Independência do Brasil apenas em 1823, após a esquadra de Lord Cochrane render os portugueses.

${ }^{9}$ Alguns apontam o dia 13 de dezembro como o início da revolta, após o grupo conservador assumir o poder. Neste dia, um grupo de vaqueiros liderados por Raimundo Gomes invade a cadeia local para libertar amigos presos e esta invasão possibilita a ocupação de todo o vilarejo.
} 
rurais, senhores de engenho e fazendeiros, que se implantara no país (Prado Junior, 1979).

A "guerra" entre os quilombos e a sociedade já estava em andamento quando da eclosão da Balaiada. Os quilombolas que lutaram na revolta eram liderados por Cosme Bento das Chagas. Em 1839, em carta à Assembleia Legislativa, o presidente da província, Sousa e Mello, descreve uma insurreição iniciada por Cosme em várias fazendas, simultaneamente:

[...] de meado para fins de Novembro manifestou-se na comarca de Itapecuru e nas vizinhanças do Rosário uma pequena insurreição d'escravos, a que dera lugar o abandono em que, por causa da rebelião, se achavam as Fazendas, e as sugestões e um escravo por nome Cosme, evadido das Cadeias d'esta Cidade, quem aproveitou o ensejo para induzir os escravos de alguns vinte sítios a subtraírem-se ao domínio dos seus senhores, pegando das armas e proclamando-se livres (Assunção, 1996: 444).

Nesta situação, os lavradores deixavam suas fazendas e a instabilidade facilitava, e muito, a fuga dos escravos e a formação de diversos quilombos. Ao que parece, Cosme conseguiu reunir até 3 mil homens em sua luta. Isso se deve ao fato de ele prometer a liberdade, além de firmar cartas de alforria de seu próprio punho ${ }^{10}$ ou obrigar os proprietários a assinar a carta de alforria de seus escravos, como aconteceu na fazenda de Lagoa Amarela, em que obrigou o proprietário a assinar a carta de alforria de seus duzentos escravos antes de matá-lo.

Cosme e os quilombolas se juntaram à Balaiada posteriormente, quando os revoltosos já se viam sem chances diante das tropas após a chegada, em 1840, de Luís Alves de Lima, o futuro Duque de Caxias. Os revoltosos, em princípio, não levavam em consideração a questão da libertação dos escravos, que não constava na pauta dos insurretos balaios.

A estratégia de Lima era de incitar o ódio entre os povos livres e os escravizados, o que teve sucesso:

Como um dos objetivos, que me tem merecido particular atenção, para evitar futuras insurreições, é excitar o ódio entre os escravos e essa gente [os grupos rebeldes do Pio e Tempestade], mandei que aqueles rebeldes fossem bater o novo quilombo do

\footnotetext{
${ }^{10}$ Cosme era alfabetizado e reconhecia o valor de saber ler e escrever, tanto que estabeleceu uma escola de alfabetização na fazenda de Lagoa Amarela.
} 
Cosme, o que fizeram, remetendo-me os escravos capturados, e além d'estes outros muitos têm sido remetidos presos pelo Pedrosa (Assunção, 1996: 448).

A estratégia de oferecer anistia a quem ajudasse a desmantelar os quilombos e capturar os escravos fugidos deu certo e os quilombolas ficaram debaixo do fogo cruzado das tropas e dos ex-rebeldes. Cosme foi cercado em 1841, duzentos escravizados que o acompanhavam foram exterminados e ele foi condenado à morte e executado em 1842.

\subsection{Alcântara}

Alcântara fica a $22 \mathrm{~km}$ de faixa de mar da ilha de São Luís, o acesso à cidade se dá pela travessia da Baía de São Marcos por meio de barcos e dura aproximadamente uma hora e trinta minutos. As embarcações que realizam a travessia o fazem na parte da manhã e à tarde por causa da variação da maré. Outra possibilidade de acesso é por via terrestre, pela estrada federal MA-106, que dura cerca de doze horas. Há ainda a travessia de ferry boat, que pode ser realizada durante todo o dia.

Segundo dados do IBGE, em 2010, o município tinha uma população de 21.851 habitantes.

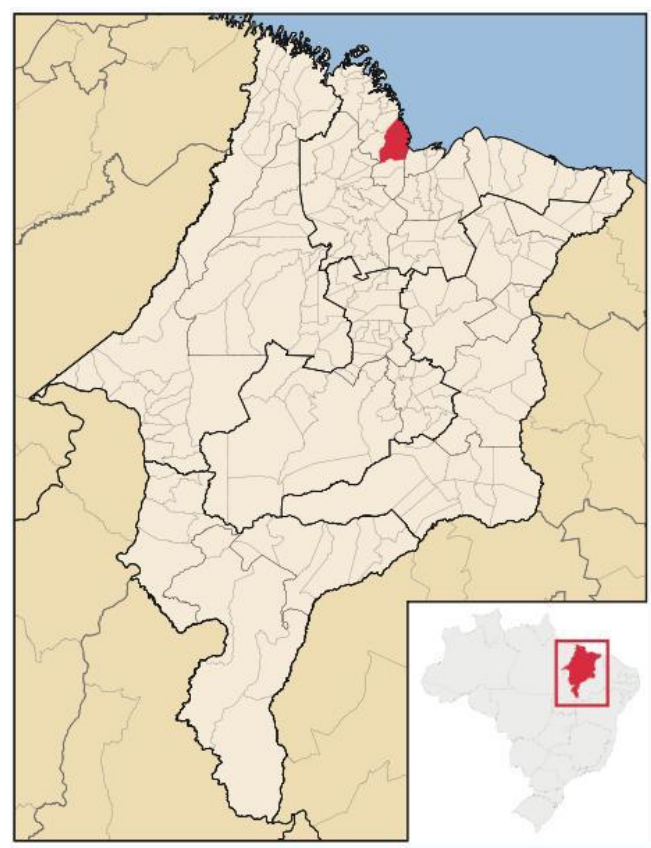

Figura 4.2: Localização de Alcântara (MA). Fonte: https://pt . wikipedia. org 
A princípio, Alcântara era uma grande aldeia de índios tapuias e tupis. O início da colonização se deu em 1612, por franceses. Os portugueses retomam o território no ano de 1615, originando a capitania de Cumã. Em 1648, com a elevação da produção agrícola e a instalação dos primeiros engenhos de açúcar, a capitania é elevada à condição de vila, tornando-se a Vila de Santo Antônio de Alcântara.

Em 1685, Alcântara era o segundo núcleo populacional da capitania do Maranhão e tinha aproximadamente quatrocentas pessoas. Nessa época a escravização indígena predominava em suas diferentes formas, embora também houvesse escravização de africanos, esta era minoria naquela época (Faria, 2012: 62).

Posteriormente, Alcântara foi considerada o "Celeiro do Maranhão" devido a sua importância como produtora e exportadora de produtos agrícolas. Nesse período era grande o número de mão de obra de africanos que, em sua grande maioria, eram de origem banta e mina-jeje.

Em 1850, Alcântara possuía 81 fazendas de cereais, 22 engenhos de açúcar, 24 fazendas de gado e para mais de 100 salinas. A decadência econômica de Alcântara tem início em 1865, com a transferência da produção açucareira do litoral para os vales (Braga, 2011).

Após 1865 a conjuntura muda e alguns fatores contribuem para o declínio de Alcântara: baixa do preço internacional do algodão, abolição da escravatura, mão de obra sendo vendida às minerações do sul, evasão dos latifundiários e omissão do poder público, diante disso, a economia da cidade foi desestruturada. As fazendas passaram por um processo de desagregação e foram entregues a antigos escravizados. As ordens religiosas (Carmelitas e Mercedários) também desocuparam suas propriedades e as repassaram à Igreja ou ao Estado.

O surgimento das comunidades negras rurais de Alcântara estabeleceuse em grande parte das terras que foram abandonadas e ficaram, ao longo de quase duzentos anos, sob a égide dos trabalhadores negros, dos escravos fugidos, dos índios, e dos mestiços que lá permaneceram. São 155 comunidades quilombolas no município e a população residente nestas comunidades corresponde a $80 \%$ da população total de Alcântara. Pelos critérios da Fundação Palmares, Alcântara está dividida em três grandes territórios quilombolas: o território dos atingidos pela Base Espacial de Alcântara, a Ilha do Cajual e as Terras de Santa Teresa ou Itamatatiua.

A partir do início do século XIX, aumentam significativamente os registros administrativos sobre quilombos na região de Alcântara, cujas primeiras ocorrências datam desde o início do século XVIII. Há o registro de sucessivas ocorrências de quilombos entre 1837 e 1868 (Almeida, 2006b). 
O fato de grande parte dos quilombos ter se formado devido ao abandono das terras pelos proprietários gerou um fenômeno interessante. Os que ficaram na terra adotaram o sobrenome dos antigos donos como um meio de legitimar a posse das terras - o sobrenome da aristocracia os consolidava como herdeiros legítimos das terras ocupadas. No caso específico de Itamatatiua, os moradores adotaram o sobrenome "de Jesus", em homenagem à Santa Teresa d'Ávila (Teresa de Jesus), tida como a verdadeira dona das terras.

Sobre as ações dos quilombolas, Almeida (2006b: 115) observa que

As ações dos quilombolas em Alcântara se intensificam a partir da primeira década do século XIX. Em razão inversa à desagregação das grandes plantações de algodão e de cana-de-açúcar, os quilombos expandem seu processo produtivo e ampliam suas relações em diferentes circuitos do mercado de produtos alimentares, marcando presença nos pequenos portos e nas vias de acesso às vilas de toda a região, sobretudo Alcântara, Guimarães, Turiaçu e Viana.

Os registros apontam para uma produção regular e um constante contato entre os comerciantes e os quilombos que concorriam pelo abastecimento de farinha e arroz das fazendas, dos núcleos urbanos regionais e também de São Luís. Os produtores das comunidades estabeleceram-se como um campesinato e vendiam livremente seus produtos, o que sugere que as comunidades de Alcântara também não eram tão isoladas assim. 


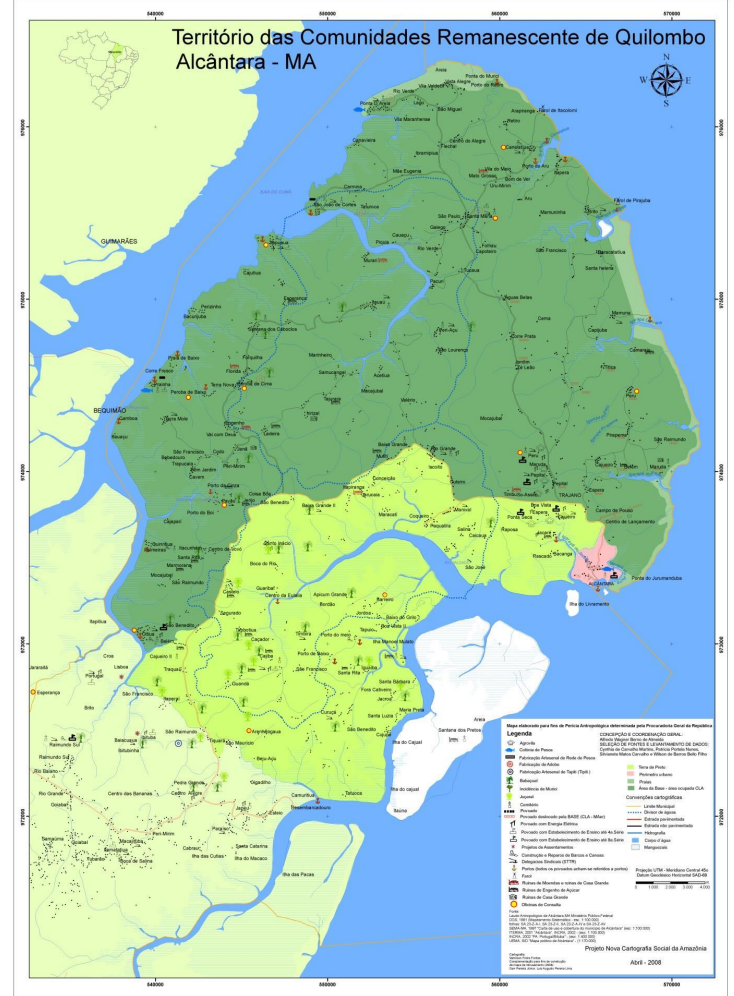

Figura 4.3: Território das Comunidades Remanescentes de Quilombos em Alcântara/MA. Fonte: Almeida (2006b)

Hoje, Alcântara é considerada patrimônio histórico-cultural, tombado em 1948 pelo Instituto do Patrimônio Histórico e Artístico Nacional (IPHAN).

Interessante observar que havia pouco conhecimento sobre a população de Alcântara até a chegada da Base, na década de 80 do século XX. Só a partir desse fato é que começaram os estudos sobre as comunidades existentes no local.

Através do decreto ${ }^{0} 7.720$, de 1980, o Governo do estado do Maranhão desapropriou 52 mil hectares de terras quilombolas para fins de utilidade pública que visava a implantação da Base de Lançamento de Alcântara. Em 1991, o Governo Federal, através do decreto presidencial n ${ }^{0} 72.571$, ampliou a área para 62 mil hectares, o que corresponde a mais da metade das terras do município de Alcântara, que tem 114 mil hectares.

Diante desse decreto, em 1987, 312 famílias de 23 povoados quilombolas foram transferidas e realocadas, pela Aeronáutica, em sete agrovilas, Marudá, Ponta Seca, Só Assim, Cajueiro, Espera, Peru e Pepital, onde residem até hoje. As indenizações referentes ao deslocamento nunca foram pagas às famílias. 


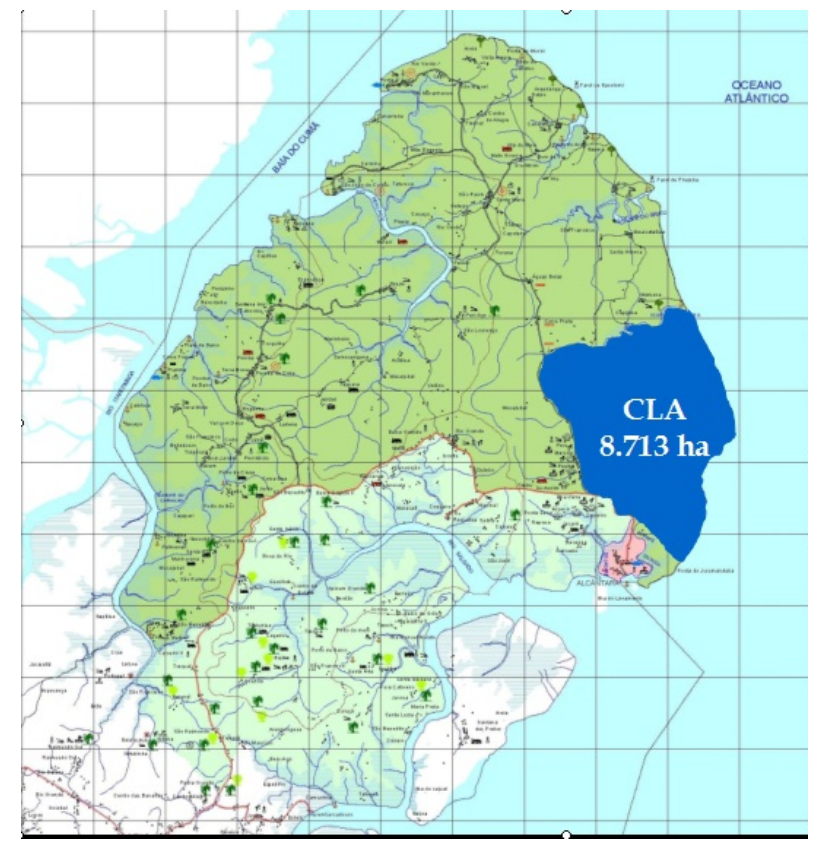

Figura 4.4: Área do Centro de Lançamento, Alcântara/MA

Desnecessário falar que este ato desestruturou as relações sociais construídas pelos moradores dos 23 povoados, além do impacto de agrupar essas comunidades em apenas sete agrovilas, com um território muito menor que aquele no qual os moradores estavam acostumados a viver, gerando uma pressão demográfica sobre os mesmos recursos. Outro agravante foi o fato de se deslocarem esses moradores para um território longe do mar, principal fonte de sustento das comunidades afetadas pela implantação da Base. De acordo com o depoimento de alguns moradores da comunidade de Mamuna, a situação das famílias que foram deslocadas para as agrovilas começou a se estabilizar somente uma década após a transferência ${ }^{11}$.

Após a implantação da Base, os moradores de Alcântara, em especial os atingidos pela Base, começaram a se organizar em luta pelos direitos formando organizações como o Sindicato dos Trabalhadores Rurais de Alcântara (STTR), que já existia, mas começou a atuar de forma mais ativa, o Movimento dos Atingidos pela Base Espacial em Alcântara (MABE), entre outros. Foi após essa movimentação e conscientização dos moradores da

\footnotetext{
${ }^{11}$ Alguns relatos apontam outros problemas que surgiram como consequência desse deslocamento compulsório e posterior perecimento das condições de vida dos moradores dessas agrovilas, como, por exemplo, a violência, as drogas e a prostituição.
} 
área rural de Alcântara através de seminários, cursos e eventos que eles começaram a se autoidentificar como quilombolas ${ }^{12}$.

\subsection{Itamatatiua}

Itamatatiua é o principal povoado de uma rede de 42 comunidades que formam as chamadas terras de Santa Teresa. Está localizado no município de Alcântara, ao norte do Maranhão, e dista 90km de São Luís, capital do estado, e a $70 \mathrm{~km}$ da sede de Alcântara ${ }^{13}$. O acesso à comunidade pode se dar por meio de ônibus que faz a linha diária entre os municípios de Alcântara e Bequimão, ou por meio de carro particular, ou ainda de moto ou moto-táxi. O nome da comunidade é de origem indígena e significa pedra, peixe e rio.

Também é possível chegar à comunidade por meio do ferry boat que sai todos os dias do Porto da Ponta da Madeira, em São Luís, e aporta no Porto do Cujupe, em Alcântara. É um trajeto de aproximadamente $22 \mathrm{~km}$ e uma hora e meia de duração. Após a chegada ao Cujupe, são mais 15km até a comunidade, por meio da rodovia MA 106.

O núcleo da comunidade, ou, como chamam os moradores, o sítio, fica a $1,5 \mathrm{~km}$ da estrada e o acesso é feito por uma pequena estrada de terra, chamada de ramal. A comunidade possui uma igreja, uma escola, um cemitério, uma pousada, uma quadra poliesportiva, um centro de produção de cerâmica, o barracão da Santa Teresa e algumas casas, quase todas de alvenaria.

\footnotetext{
${ }^{12}$ Há diversos estudos que tratam da atuação do MABE e de outros movimentos sociais nesta questão da implantação do CLA, como, por exemplo, Silva (2013) e os trabalhos realizados no âmbito do projeto Nova Cartografia Social da Amazônia, que podem ser acessados através do endereço eletrônico http://novacartografiasocial.com/.

${ }^{13}$ Devido à localização da comunidade, ela está fora da área atingida pela implantação do CLA.
} 


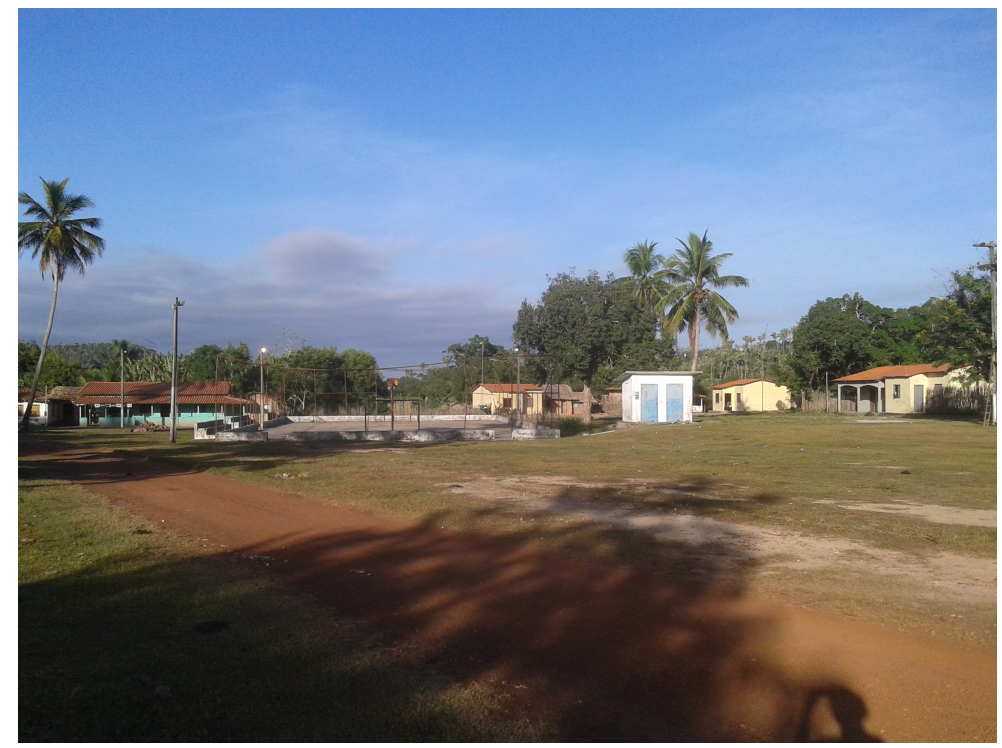

Figura 4.5: Visão da entrada da comunidade de Itamatatiua, Alcântara/MA

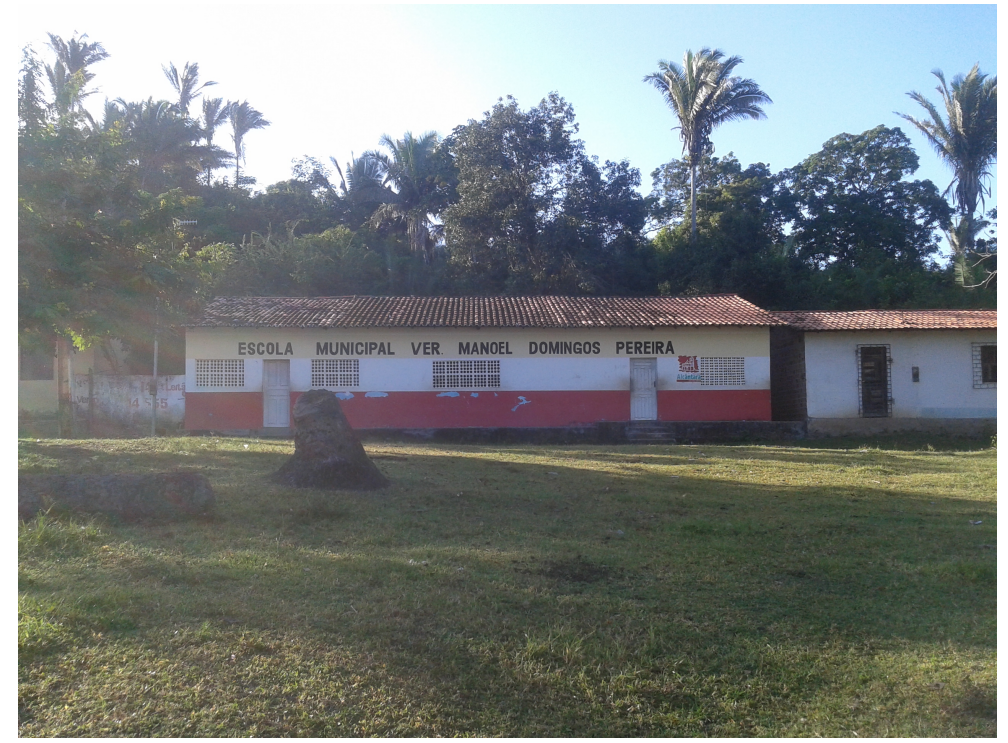

Figura 4.6: Escola municipal, comunidade de Itamatatiua, Alcântara/MA

A comunidade possui luz elétrica e um ponto de acesso à internet wi-fi no centro da comunidade, próximo à escola, além de água encanada. No entanto, o encanamento é abastecido apenas duas vezes ao dia, o que afeta a rotina dos moradores que têm de encher vasilhas para armazenar a água, além de lavar roupas e tomar banho no momento em que o encanamento está sendo abastecido. 
As comunidades de Alcântara receberam luz elétrica apenas no século XXI, quando foi lançado, em 2003, por meio do decreto $\mathrm{n}^{\circ} 4.873$, o Programa Luz para Todos, do Governo Federal.

Embora possua uma pousada, esta não funciona sempre, apenas quando algum grupo de pesquisadores ou visitantes estão na comunidade. Fora esses casos, a pousada permanece fechada.

A formação desse grupo não surgiu da fuga de negros escravizados. Com a decadência econômica de Alcântara, a Ordem das Carmelitas, dona da propriedade desde 1754, não teve mais condições materiais, a partir de 1821, de manter o local, deixando-o. Com a saída das Carmelitas, os grupos que ali viviam permaneceram, estabelecendo seus próprios meios de sobrevivência sem deixar de lado a tradição de produção de cerâmica (Pereira, 2011; Cestari et al., 2014; Almeida, 2006b; Pereira Júnior, 2012).

Os quilombos existentes nas terras de Santa Teresa, onde fica Itamatatiua, foram duramente reprimidos em 1837, mas não foram destruídos.

De acordo com os relatos de moradores, a comunidade teria mais de 300 anos, tendo surgido por volta de 1700, porém os relatos não condizem com as informações históricas. Contando com a saída da Ordem das Carmelitas, por volta de 1821, a comunidade de Itamatatiua teria, aproximadamente, 200 anos.

As fontes de renda dessa comunidade são a agricultura de subsistência, a cerâmica e a aposentadoria dos mais velhos. Há ainda, como complemento da renda, o recebimento de benefícios de programas do Governo Federal, como o Bolsa Família, por exemplo.

Apesar de ter a certidão de reconhecimento desde 2006, emitida pela Fundação Palmares, a comunidade ainda luta pela titulação definitiva das terras no INCRA.

Após a morte do líder Eurico de Jesus, em 1991, a comunidade começa a ser liderada pela filha dele, Neide de Jesus, e tem início uma espécie de matriarcado na comunidade. Hoje, dona Neide continua como líder da comunidade com o apoio de outras mulheres que assumem o comando da Associação, do Centro de Cerâmica e outras posições de liderança. A presidência da Associação, por exemplo, que administra o centro de cerâmica e a pousada, só pode ser exercida por mulheres. Diversas decisões políticas da comunidade passam pela Associação, como, por exemplo, as relações com agências governamentais, com movimentos sociais, entre outras.

A principal atividade da comunidade e fonte de renda é a confecção de cerâmicas pelas mulheres. Itamatatiua é tradicionalmente conhecida pela cerâmica feita na comunidade e essa atividade já proporcionou a essas 
mulheres diversas viagens pelo país para exposição e venda em feiras no Rio de Janeiro, Pará, Minas Gerais, entre outros estados.

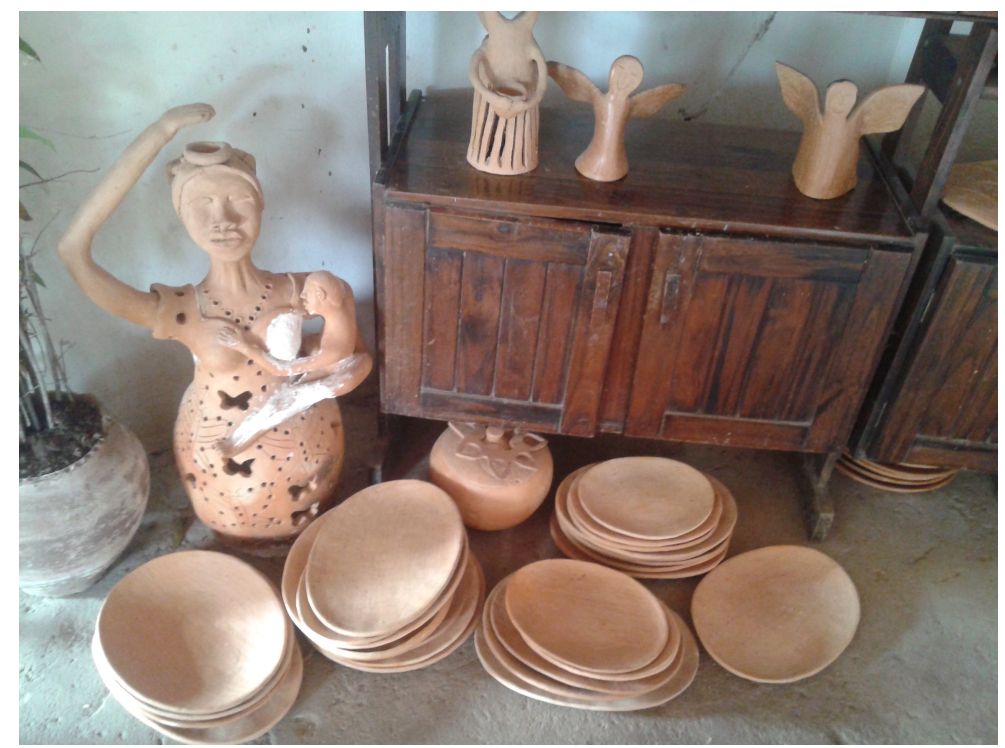

Figura 4.7: Peças de cerâmica produzidas na comunidade de Itamatatiua, Alcântara/MA

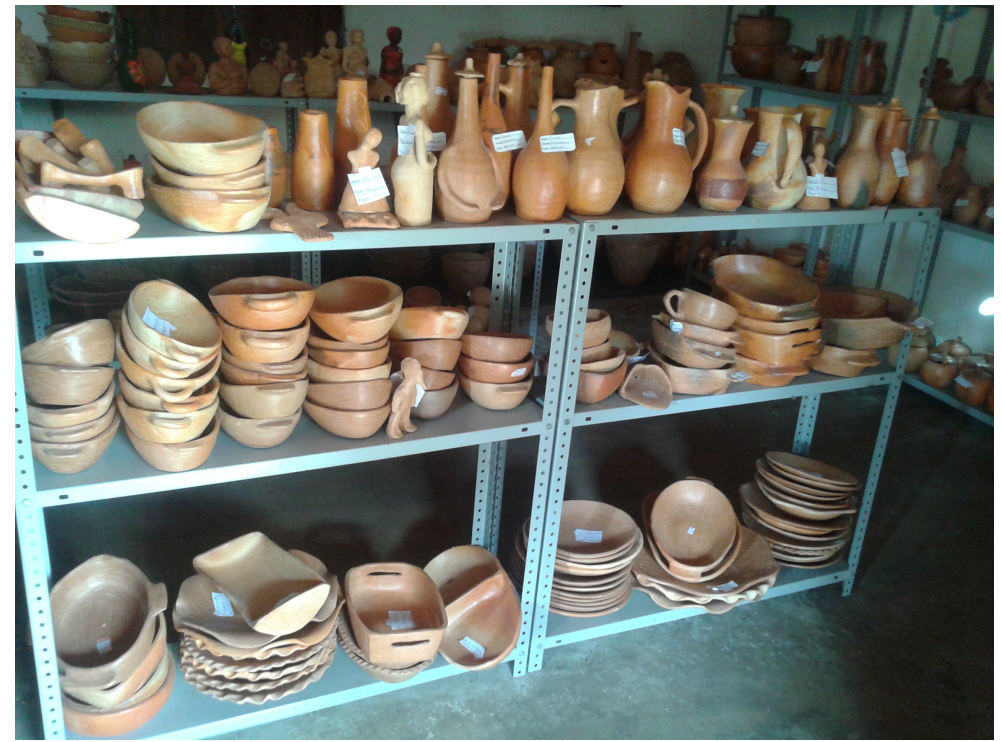

Figura 4.8: Peças de cerâmica produzidas na comunidade de Itamatatiua, Alcântara/MA 
Observou-se, no relato dos moradores, uma preocupação com a tradição da comunidade, tanto na feitura da cerâmica quanto em relação à plantação e criação de animais, pois há um desinteresse por parte dos mais novos em continuar essas atividades. Não há mulheres jovens envolvidas na confecção da cerâmica, exceto a filha de Neide de Jesus, líder da comunidade. Ao que parece, uma boa parte dos jovens se vale da renda da aposentadoria dos mais velhos ou prefere sair da comunidade para trabalhar.

Itamatatiua é conhecida como a comunidade mais tradicional de Alcântara, tanto pela festa de Santa Teresa quanto pela cerâmica produzida na comunidade, e tem sido estudada por pesquisadores de diversas áreas, em especial na área antropológica. Em vista disso, os moradores já estão acostumados a receber pesquisadores e, segundo relatos, sempre há alguém na comunidade realizando algum trabalho de campo. Logo, não é difícil encontrar trabalhos com informações sobre a comunidade, sobre a sua origem, localização e tradição, diferentemente de outras em Alcântara que não são tão estudadas, como Mamuna, por exemplo.

\subsection{Mamuna}

Diversamente de Itamatatiua, os estudos específicos sobre Mamuna são mais escassos - talvez até inexistentes. Em geral, os que existem são estudos a respeito do conflito com o Centro de Lançamento de Alcântara e tratam sempre das comunidades de Mamuna, Baracatatiua e Brito em conjunto, pois são as comunidades ameaçadas de deslocamento.

No laudo antropológico de Almeida (2006b) consta que, àquela época, havia em Mamuna 215 habitantes e 56 famílias. Relatos de moradores da comunidade afirmam que são 71 famílias vivendo na comunidade atualmente.

A comunidade fica na área litorânea de Alcântara e o acesso é feito por meio de carro, moto ou moto-táxi, não há uma linha de ônibus que passe pela comunidade.

Enquanto Itamatatiua é conhecida pela cerâmica e pela tradicional festa de Santa Teresa, sobre as quais incidem grande parte dos estudos feitos sobre essa coletividade, Mamuna é conhecida pela luta em relação à implantação da Base em Alcântara, tomada como a principal comunidade no tocante à resistência em relação às tentativas do Governo Federal de deslocar as comunidades litorâneas restantes na área de interesse da Aeronáutica. 


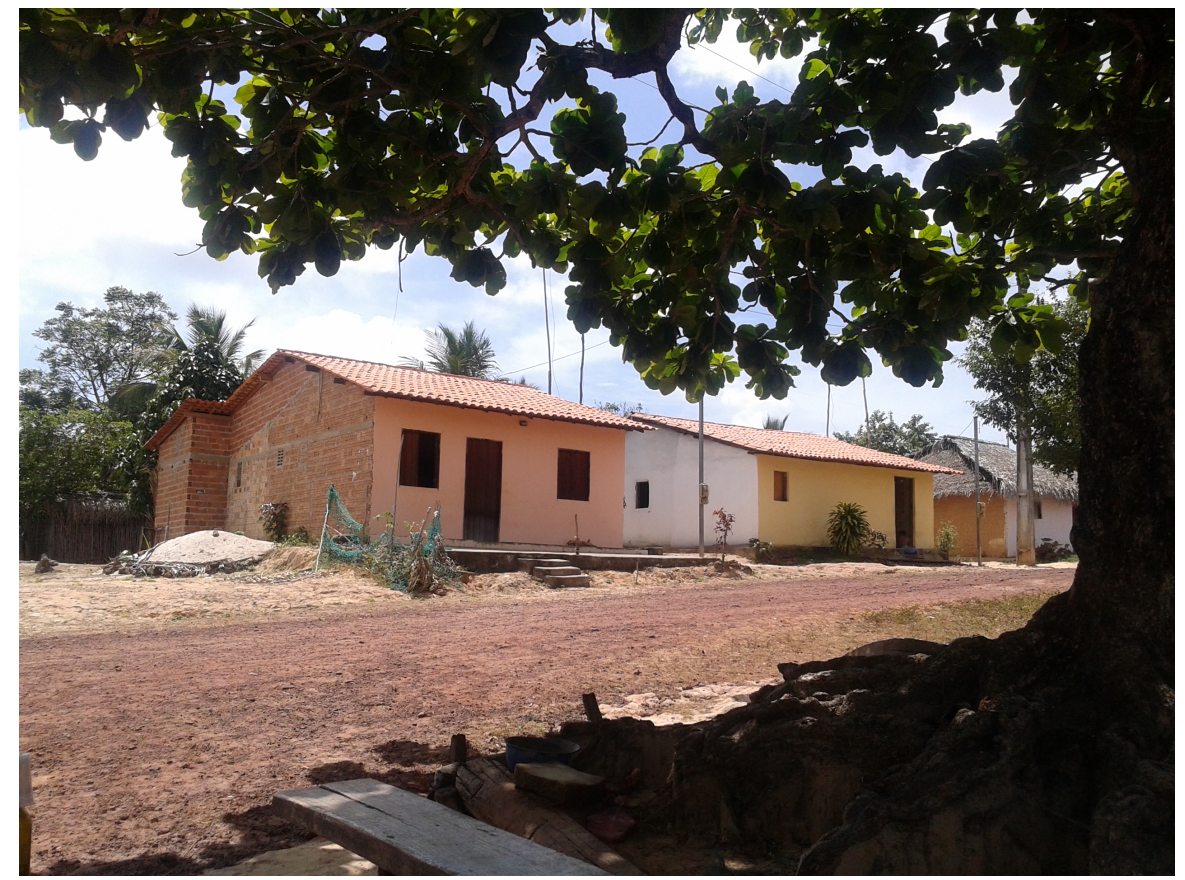

Figura 4.9: Comunidade de Mamuna, Alcântara/MA

Devido aos constantes conflitos com o Governo Federal em relação à desapropriação da comunidade, ainda há, em Mamuna, um número maior de casas de taipa, se comparado às outras comunidades. Além disso, segundo relatos dos moradores, durante anos evitou-se investir nas casas devido à possibilidade iminente de deslocamento dos habitantes de Mamuna.

A constante ameaça de deslocamento afetou o modo de vida dos moradores em Mamuna, não apenas pelo fato de eles não investirem em suas casas, o que está mudando nos últimos anos, mas pela forma de recepção das pessoas de fora também. Devido às diversas e diferentes investidas do Governo Federal, e pelo fato de já terem sido enganados diversas vezes por agentes tanto do governo quanto das empresas interessadas na área da comunidade, há uma constante desconfiança em relação às pessoas que vêm fazer pesquisa. Os moradores sempre questionam, diversas vezes, a respeito do que trata a pesquisa e são receosos também quando se tira fotos da comunidade.

Em 2003, o governo brasileiro assinou um acordo com a Ucrânia para a exploração da Base de Alcântara. Os dois governos gastaram cerca de R \$ 1 bilhão no projeto. O foguete seria lançado através de uma empresa conjunta, a Alcântara Cyclone Space (ACS). Os atrasos e conflitos em relação ao território levaram ao cancelamento do acordo em 2015. 
Em 2008, a empresa Alcântara Cyclone Space invadiu o território utilizado para roça pelas comunidades de Mamuna e Baracatatiua realizando desmatamento junto às nascentes de rios e igarapés, destruindo a mata ciliar, derrubando árvores e abrindo estradas ilegais. O IBAMA puniu a empresa por crime ambiental, tendo esta de pagar duas multas de sete mil reais ${ }^{14}$ (Pereira Júnior, 2009).

Com a eleição de Donald Trump nos Estados Unidos, o governo de Michel Temer voltou a negociar o lançamento de foguetes norte-americanos do Centro de Lançamento de Alcântara, negociações essas que tinham sido iniciadas no final do governo Fernando Henrique Cardoso (1995-2002) e, devido às diversas imposições do governo norte-americano, como a proibição do governo brasileiro de lançar foguetes próprios da base, foram canceladas pelo presidente Luiz Inácio Lula da Silva.

Não se sabe ainda como esse retorno das negociações pode afetar as comunidades litorâneas de Alcântara, porém o STTR, o MABE e o Movimento de Mulheres Trabalhadoras de Alcântara (MOMTRA) já se posicionaram em relação a essas negociações em carta publicada em 19/02/2017 (nos anexos).

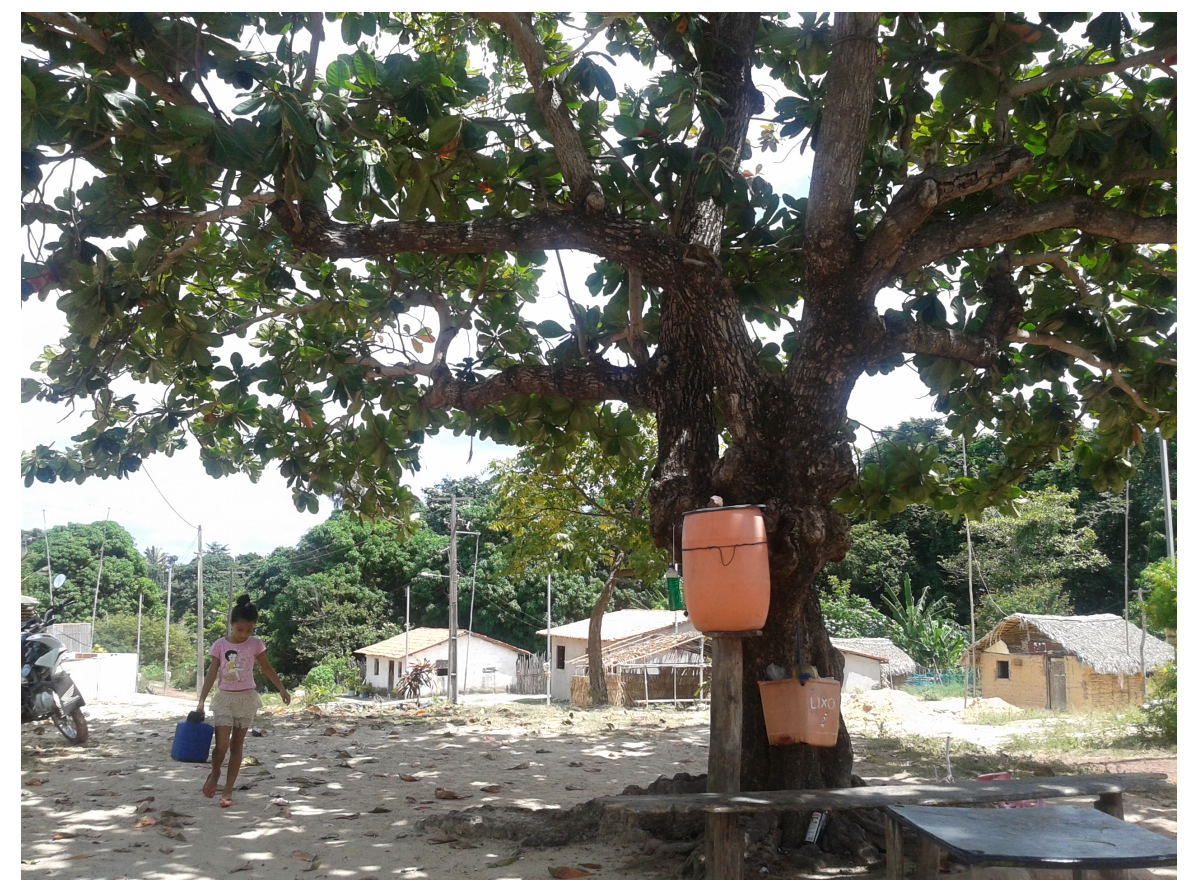

Figura 4.10: Comunidade de Mamuna, Alcântara/MA

\footnotetext{
${ }^{14}$ Pereira Júnior (2009) fez um estudo detalhado sobre a ação da ACS junto às comunidades de Mamuna, Baracatatiua e Brito, apontado os perigos dessas ações para as comunidades e as possíveis consequências e alterações no modo de vida da população.
} 


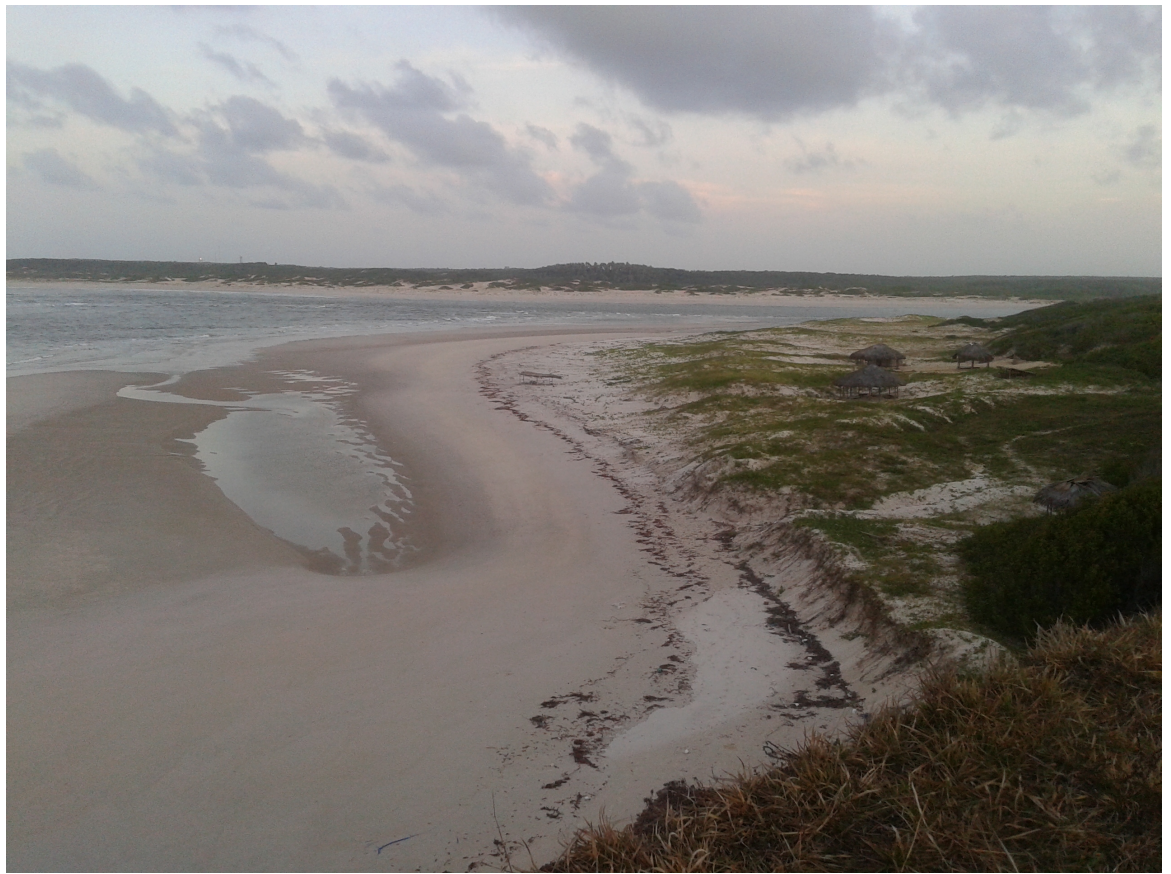

Figura 4.11: Praia de Mamuna, Alcântara/MA

Mamuna é liderada por uma mulher, Militina Garcia Serejo, professora do ensino primário em Alcântara e Peru e, assim como em Itamatatiua, as demais figuras de liderança da comunidade também são mulheres. Não há escola na comunidade, as crianças estudam na agrovila do Peru, próximo à Mamuna. Um ônibus da prefeitura é encarregado de buscar e levar as crianças todos os dias, porém, nem sempre é o que acontece. Por vezes, o ônibus fica uma semana sem passar na comunidade e, consequentemente, as crianças não vão à escola. E essa é uma das principais reclamações dos moradores, a ausência de uma escola na comunidade, bem como o descaso da prefeitura em relação ao transporte escolar encarregado de levar as crianças à escola na comunidade de Peru.

A comunidade tem luz elétrica ${ }^{15}$ e água encanada, porém os encanamentos são abastecidos duas vezes ao dia, o que leva os moradores a terem de armazenar água para poderem utilizar nos afazeres domésticos. Não há ponto de internet na comunidade, o sinal de telefone só fica disponível na área da praia, que dista cerca de dez minutos a pé da comunidade. Alguns moradores possuem telefone fixo em casa, mas são poucos.

\footnotetext{
${ }^{15}$ Assim como Itamatatiua, a comunidade de Mamuna recebeu luz elétrica somente nos anos 2000, através do programa do governo federal Luz Para Todos.
} 
As principais atividades em Mamuna são a pesca, a extração do óleo de mamona - daí o nome da comunidade - tucum e carnaúba, azeite de babaçu, a farinha de mandioca e as roças para consumo próprio. Outras fontes de renda desta comunidade são a aposentadoria dos mais velhos e os programas sociais do Governo Federal, como o Bolsa Família. De modo semelhante à Itamatatiua, há uma preocupação em relação à postura dos mais jovens no tocante à continuação das atividades tradicionais da comunidade. Em Mamuna também existe um desinteresse por parte da população mais jovem que, em grande parte, vive da aposentadoria dos mais velhos.

\subsection{Considerações do capítulo}

O Maranhão é o segundo estado em número de negros do país e foi o maior em número de população negra escravizada, o que gera consequências para a população negra do estado ainda nos dias de hoje. $\mathrm{O}$ fato de a vida dos escravizados ter sido muito dura no Maranhão, tanto em relação aos maus-tratos dos senhores, como ao trabalho, além do descaso do governo, levou à insurreição da população escravizada, com a consequente fuga e formação de quilombos.

O estado é considerado uma sociedade de escravização tardia. Apesar das tentativas de impulsionar a economia maranhense durante o período colonial, a intensificação do comércio e do tráfico de africanos escravizados só teve impulso após a criação da Companhia Geral do Grão-Pará e Maranhão, em 1755, apresentando os traços de uma escravidão agrícola desenvolvida apenas no último quarto do século XVIII. O apogeu do comércio e da economia se deu de meados do século XVIII até o final do XIX, com dois grandes ciclos econômicos, o Ciclo do Algodão, até 1868, e o do Açúcar, de 1868 até 1894. Este último teve início 18 anos após o decreto que proibia o tráfico de africanos e finalizou após 6 anos da abolição da escravidão.

O Maranhão recebeu então as últimas "levas" de africanos que chegaram ao Brasil, bem como negros escravizados de outras regiões que migravam de acordo com as necessidades econômicas da época. Como consequência, a formação dos quilombos no estado também foi tardia. A intensificação do surgimento dos quilombos se deu após a independência do Brasil e, especialmente, com a Balaiada, ocorrida entre 1838 e 1841.

O ambiente de revolta na época da Balaiada facilitou a formação de quilombos no Maranhão. Outro facilitador da fuga era a grande área coberta de matas em torno das fazendas, o que pode ser visto pela quantidade de 
comunidades remanescentes de quilombos que existem hoje no estado, em torno de 400.

Uma informação pertinente sobre a cidade de Alcântara é que ela é relativamente isolada de São Luís. O acesso se dá por barco ou por doze horas de estrada - ver seção 4.3 - e isso faz com que a própria cidade tenha mantido um certo isolamento em relação à capital do estado e, consequentemente, as comunidades quilombolas desse município também eram mais isoladas.

Embora muitos moradores afirmem que as comunidades têm mais de 300 anos, a história de formação da cidade mostra que não é bem assim. O próprio estado do Maranhão passou a receber os africanos em grande quantidade no último quarto do século XVIII, e o apogeu econômico de Alcântara se deu em meados do século XIX.

Uma característica dos quilombos de Alcântara é que muitos deles se formaram pelo abandono das terras por seus donos, como Itamatatiua, por exemplo, e esse fato teve início a partir do declínio econômico da cidade, com início em 1865, logo, boa parte das comunidades teria menos de 200 anos.

Este fato leva a pensar que, muito provavelmente, estes moradores mais velhos das comunidades quilombolas de Alcântara seriam a segunda geração, ou terceira para os que estão na faixa dos 40 e 50 anos, descendentes dos escravizados e ex-escravizados que formaram estes quilombos, carregando ainda muitos traços da fala de seus ancestrais.

Do mesmo modo que a formação dos quilombos se deu tardiamente, se comparado ao restante do país, especialmente em Alcântara, a autodeclaração dessas comunidades como remanescentes de quilombos veio mais tarde ainda, tendo início principalmente após a implantação da Base da Aeronáutica, na década de 80 do século XX, que gerou conflitos territoriais. A questão da posse da terra também foi um fator importante para esse autorreconhecimento, embora a grande maioria não possua a titulação da terra.

Interessante sempre observar que os quilombos não permaneceram isolados do restante da sociedade, como é comum pensar. Muito pelo contrário, estabeleciam comércio com a população livre, vendiam produtos agrícolas, mantinham contato com os escravizados que não conseguiam fugir das fazendas e comunicavam-se entre si, e estes fatores ajudaram não só para a formação, mas também para a permanência desses quilombos enquanto comunidades.

Durante toda a época de surgimento dos quilombos maranhenses, eles foram perseguidos pelas tropas que representavam o governo, ou pelos capitães do mato dos senhores das fazendas, ou ainda por pessoas livres 
que buscavam alguma recompensa. A fuga das fazendas não significava paz e liberdade, eles eram constantemente perseguidos, tendo que mudar de local e, muitas vezes, as pessoas que fugiam eram capturadas e levadas aos seus antigos donos.

Sobre a relevância das comunidades quilombolas para o entendimento da formação do português brasileiro, Mattos e Silva (2004: 87), assim como outros autores, chama atenção ao fato de a constituição humana e social dos quilombos apresentar significativo interesse para a história linguística do Brasil, pois eram agrupamentos sociais que, embora isolados, se articulavam com a sociedade considerada legítima.

A autora levanta a hipótese de que, nessas comunidades, em termos linguísticos, coabitariam diversos falares correntes aqui no Brasil, as línguas africanas, indígenas, português africanizado, português indígena e até português europeu, e se configurariam como laboratórios de formação de um português geral brasileiro. Aponta ainda o fato de que esses "espaços ilegítimos da escravidão" seriam, assim como os legítimos, fortes candidatos à difusão de um português geral brasileiro. Apresenta ainda a seguinte citação:

[o]s quilombolas brasileiros ocuparam sertões e florestas, cercaram e penetraram em cidades, vilas, garimpos, engenhos e fazendas; foram atacados, usados por grupos escravistas, aos quais também atacaram e usaram em causa própria; fugiram da escravidão e se comprometeram com a escravidão; combateram e se aliaram com outros negros, índios e brancos pobres; criaram economias próprias e muitas vezes prósperas; formaram grupos pequenos, ágeis, móveis e temporários, ou grupos maiores, sedentários, com gerações que se sucediam, politicamente estruturados; envolveram-se com movimentos políticos de outros setores sociais, desenvolveram seus próprios movimentos (Reis \& Gomes, 1996: 23).

Em suma, a organização das comunidades quilombolas apresenta uma ecologia interessante para pesquisa linguística, uma vez que conviveram diferentes 'falares' em um ambiente relativamente isolado, pois muitas dessas comunidades estabeleciam relações com a sociedade externa. $\mathrm{O}$ fato de ser um ambiente em que os aquilombados gozavam de uma certa liberdade, longe dos maus-tratos dos senhores das fazendas e das horas extenuantes de trabalho, possibilitava uma interação linguística mais ampla.

As comunidades de Alcântara seriam ainda especialmente interessantes, não só por seu certo isolamento em relação a São Luís e ao restante do 
estado, mas também por sua formação relativamente recente, estando a geração dos moradores atuais não muito distante daquela que formou esses povoados. Tendo em vista essas questões, acredita-se, salvaguardadas as devidas proporções, que algumas dessas comunidades podem ainda preservar, de modo mais manifesto, resquícios desse contato. 


\section{Capítulo 5}

\section{Concordância Verbal de Terceira Pessoa do Plural}

Nas discussões sobre o contato linguístico no português do Brasil, fenômenos que sempre aparecem como indicadores deste contato são a morfologia verbal e a variação na marcação de plural, em especial da terceira pessoa. Diversos estudos comparativos apontam para diferenças entre $o$ português do Brasil (PB), ou brasileiro, e o português europeu (PE) (Monte, 2015; Rubio, 2012; Holm, 2011; Gonçalves \& Rubio, 2010; Monguilhott, 2009, entre outros).

Conforme evidenciado anteriormente, esta tese parte do pressuposto de que as mudanças ocorridas no PB são oriundas do contato entre o PE, as diferentes línguas africanas trazidas para cá na época da colonização e as diversas línguas indígenas presentes no Brasil. Diante disso, não entrarei na discussão sobre contato versus deriva. Para maiores esclarecimentos sobre essa discussão, consultar os trabalhos de Scherre \& Naro (1997), Lemle \& Naro (1977), Naro (1981), Guy (1981), entre outros.

A variação na concordância verbal $(\mathrm{CV})$, bem como as diferenças entre o brasileiro e o PE quanto a este fenômeno, já foi tratada por um grande número de trabalhos e estes o fazem, em sua maioria, sob uma perspectiva sociolinguística variacionista, logo, precisarei de algumas noções e nomenclaturas dessa perspectiva para poder dialogar com análises anteriores e os resultados apresentados por elas.

Apresento, de modo sucinto, os trabalhos que tratam da variação na concordância verbal, tanto os que comparam o PB com o PE quanto os que estudam somente o PB como os que analisam as variedades do português faladas na África. Nestes trabalhos, são analisados dados de fala popular urbana, urbana culta e popular não urbana - critérios estabelecidos de acordo com maior ou menor escolaridade - , e alguns desses trabalhos 
comparam essas variedades entre si. O trabalho Lemle \& Naro (1977) tem um marco importante para os estudos sobre a variação na $\mathrm{CV}$, pois aponta para a relação entre a variação na concordância verbal e a saliência fônica do verbo, variável que se mostrará relevante nos estudos posteriores sobre a variação da $C V$.

Algumas das variáveis exploradas nos trabalhos de variação da concordância verbal realizados em uma perspectiva sociolinguística variacionista não se mostrarão pertinentes neste momento da análise dos dados das comunidades quilombolas alcantarenses, o que ficará claro no próximo capítulo, contudo, apresento brevemente alguns dos trabalhos mais recentes, dando preferência aos escritos entre o ano de 2009 e hoje $^{1}$, para localizar o leitor no modo como este fenômeno tem sido estudado.

\subsection{Português brasileiro e português europeu}

Para os estudos que analisam a variação na marcação de plural no verbo de terceira pessoa e comparam dados do português do Brasil e do português europeu, apresento os trabalhos de Monguilhott (2009), Rubio (2012) e Monte (2015).

Importante observar que, na perspectiva Sociolinguística Variacionista, há três frequências, as quais podem identificar um fenômeno como variável, semicategórico ou categórico (Labov, 2003: 241-243 em Monte, 2015):

\begin{tabular}{|l|c|}
\hline Tipo de regra & Frequência \\
\hline \hline I - Categórica & $100 \%$ \\
II - Semicategórica & $95-99 \%$ \\
III - Variável & $5-95 \%$ \\
\hline
\end{tabular}

Diante disso, se a marcação de concordância de terceira pessoa do plural, que é o objeto deste capítulo, ocorre entre 5 e 95\% dos casos, esta regra é considerada variável e isso significa que a variação é sistemática, e não livre. As variantes linguísticas no caso da CV seriam duas: a presença ou a ausência de marca de plural no verbo.

Monguilhott (2009) analisa o fenômeno da CV de terceira pessoa do plural nas duas línguas em amostras de dados sincrônicas e diacrônicas (séculos XIX e XX). Os dados sincrônicos são referentes a quatro localidades

\footnotetext{
${ }^{1}$ Abrirei exceção para um ou outro trabalho realizado anteriormente a 2009 que se fizer pertinente para a discussão que empreenderei sobre os dados alcantarenses, em especial os trabalhos que analisam dados de comunidades quilombolas.
} 
de Florianópolis - Ribeirão da Ilha e Costa da Lagoa, na zona não urbana, Ingleses e Centro, na zona urbana - e a quatro localidades de Lisboa: Cascais e Sintra, na zona não urbana, Belém e Centro, na zona urbana.

O corpus diacrônico é constituído por quatorze peças de autores de Santa Catarina, com cinco peças do século XIX e nove do século XX, e quatorze peças de autores portugueses, divididas da mesma forma, cinco do século XIX e nove do século XX.

Para a autora em questão, a concordância verbal é condicionada mais por fatores linguísticos do que por fatores extralinguísticos, tanto no PE quanto no PB.

Nos dados sincrônicos do português brasileiro, de um total de 794 contextos de terceira pessoa do plural, $640(80,6 \%)$ apresentaram marcas de plural no verbo, e 154 (19,4\%) não apresentaram qualquer marca. Para o português europeu, de um total de 807 dados, 742 (91,95\%) apresentaram marcas de concordância verbal, enquanto que 65 dados $(8,05 \%)$ não apresentaram qualquer marca de concordância ${ }^{2}$. Nesse sentido, a concordância verbal de terceira pessoa do plural pode ser considerada uma regra variável tanto no PB quanto no PE.

\begin{tabular}{|l|c|}
\hline Variedade & Ocorrência de CV \\
\hline \hline Português brasileiro & $80,6 \%$ \\
Português europeu & $91,9 \%$ \\
\hline
\end{tabular}

Tabela 5.1: Concordância sujeito verbo - PB/PE — dados sincrônicos. Fonte: Monguilhott (2009).

Em uma análise quantitativa geral dos dados, é possível dizer que o PE apresenta maior percentual de marcação de plural no verbo de terceira pessoa em relação ao $\mathrm{PB}$, com uma diferença de pouco mais de 10 pontos percentuais.

Para a autora, a variável saliência fônica apresentou-se a mais relevante na análise probabilística. No português europeu, a oposição não acentuada favorece a presença de marcas explícitas de plural no verbo, correspondendo a $93 \%$ de frequência. A oposição acentuada, por sua vez, apresenta 90\% de frequência na marcação de CV.

A saliência fônica é dividida segundo critérios propostos por Naro (1981) e possui uma escala com dois níveis classificados de acordo com a presença ou não de acento na desinência e de acordo com a quantidade de

\footnotetext{
${ }^{2}$ Optei por apresentar os resultados em percentagem, pois nem todos os trabalhos apresentam os pesos relativos ou os números absolutos.
} 
material fônico que diferencia as formas singular e plural (Monguilhott, 2009):

Nível 1: oposição não acentuada

1. a mudança da forma singular para a forma plural não envolve alteração na qualidade da vogal final da forma plural (conhece/conhecem, consegue/conseguem, corre/correm, vive/vivem, sabe/sabem);

(1) ELES não CONSEGUE alcançar nosso ritmo, né?

(2) Aí ELES não CONSEGUEM ter um bom rendimento.

(Monguilhott, 2009: 88-89)

2. a mudança da forma singular para a forma plural envolve alteração na qualidade da vogal final da forma plural (ganha/ganham, era/eram, gosta/gostam);

(3) Tenho três, quatro sobrinhos, ANDA TODOS ELES também aí ao mar.

(4) Sim, ANDAM aí UNS BRASILEIROS.

(Monguilhott, 2009: 89)

3. a mudança da forma singular para a forma plural envolve acréscimo de segmentos na forma plural (diz/dizem, quer/querem);

(5) Só que ELES DIZ que eu tenho que trabalhá pra pagá.

(6) Ah, UNS DIZI que é porque ele foi demitido.

(Monguilhott, 2009: 89)

Nível 2: oposição acentuada

1. a mudança da forma singular para a forma plural envolve apenas mudança na qualidade da vogal na forma plural (tá/tão, vai/vão);

(7) OS MEUS IRMÃOS TÁ cada um do seu lado.

(8) ELAS já TÃO o dia todo na escola.

(Monguilhott, 2009: 89)

2. a mudança da forma singular para a forma plural envolve acréscimo de segmentos sem mudanças vocálicas na forma plural (bateu/bateram, viu/viram, incluindo o par foi/foram que perde a semivogal); 
Português brasileiro e português europeu

(9) Conta COISAS QUE pra ele FOI um bocado traumáticas.

(10) AS AULAS PRÁTICAS FORAM reduzidas.

(Monguilhott, 2009: 89)

3. a mudança da forma singular para a forma plural envolve acréscimos de segmentos e mudanças diversas na forma plural como mudanças vocálicas na desinência, mudanças na raiz, e até mudanças completas (veio/vieram, é/são, disse/disseram);

\section{VEIO todos pra cá.}

VIERAM muitos imigrantes de fora pra cá.

(Monguilhott, 2009: 89)

Em cada um dos dois níveis há três categorias que variam de um menor para um maior grau de saliência fônica. Nos estudos sobre a variação da concordância verbal, a escala da saliência fônica irá interferir na marcação de plural, uma vez que as formas mais salientes (mais perceptíveis) tendem a ser mais marcadas, ao passo que as formas menos salientes serão menos marcadas.

Ou seja, quanto maior a diferença entre as formas singular e plural, maiores serão as chances de a forma plural ser marcada e, no sentido inverso, quanto menor a diferença fônica entre as formas singular e plural, maiores serão as chances de o verbo não receber a marca de plural quando na terceira pessoa do plural. Nesse sentido, o nível 2 apresenta maior probabilidade de aplicação da regra de concordância se comparado ao nível 1.

O nível 1 comporta-se de maneira diferente no PB e no PE. De acordo com alguns estudos, essa variável não seria relevante para a marcação de CV no português europeu, no entanto, os dados de Monguilhott (2009) parecem indicar efeitos contrários na aplicação desta variável nas duas línguas. Enquanto no PB o nível 1 favorece a não ocorrência de concordância verbal, no PE, esta variável favoreceria a marcação de plural.

A segunda variável pertinente para o estudo de Monguilhott (2009) foi o tipo dos verbos que foram divididos em: inacusativos prototípicos - seriam aqueles que possuem as propriedades $(+)$ posposição, $(-)$ desencadeador, $(-)$ indeterminação, (+) particípio e (-) cognato - (13); inacusativos não prototípicos (14); intransitivos prototípicos - seriam os que apresentam as propriedades (-) posposição, (+) desencadeador, (+) indeterminação, $(-)$ 
particípio e (+) cognato - (15); intransitivos não prototípicos $(16)^{3}$; transitivos (17) e cópula.

Depois SURGIU AS CARROÇAS, OS BURROS.

AS PESSOAS não SAI do Ribeirão todo dia pra vim no centro. MUITOS ESCRAVOS também TRABALHAVU nessa atividade.

Os primeiros europeus a vir pra cá foram OS ESPANHÓIS QUE APORTARAM aqui.

OS ALUNOS DÃO importância também pra esse profissional.

(Monguilhott, 2009:97-98)

Destes, o verbo inacusativo mostrou-se como o que menos favorece a marcação, com $73 \%$ para os não prototípicos e $77 \%$ de frequência para os prototípicos.

A autora observa, para as duas línguas, uma forte relação entre verbos inacusativos, a posposição do sujeito e o traço [- humano] do sujeito, todas essas variáveis desfavorecendo a marcação de $\mathrm{CV}$ e, ainda, que no verbo inacusativo não prototípico com sujeito com traço [- humano] encontra-se a menor frequência de concordância verbal.

Relevante observar que, a despeito das diferenças percentuais na marcação da CV entre o PB e o PE, a ocorrência de marcação de plural no verbo ainda representa a maioria dos dados apresentados pela autora, ou seja, a ocorrência de plural no verbo ainda ocorre com maior frequência nas duas línguas quando na terceira pessoa do plural, e a regra é variável para ambas.

A posição do sujeito apareceu como outra variável pertinente para comparação entre os dados do $\mathrm{PB}$ e do $\mathrm{PE}$. O SN posposto aparece como um fator que favorece a não ocorrência de $\mathrm{CV}$, pois, neste contexto, $66 \%$ dos dados não apresentaram qualquer marca no verbo. Este é o primeiro contexto no qual a não marcação de plural no verbo representa a maior parte das ocorrências.

O tipo de sujeito também emerge como uma variável importante, mais especificamente o SN pleno composto que apresenta $44 \%$ e $40 \%$ de frequência na ocorrência de CV para o PB e para o PE, respectivamente. Este seria, ao lado da posposição do sujeito, o segundo contexto em que a não marcação representa a maior parte dos dados. Interessante notar que o exemplo de SN composto apresentado pela autora possui o sujeito posposto:

\footnotetext{
${ }^{3}$ Os inacusativos e intransitivos não prototípicos foram definidos, pela autora, em função da não presença de alguma ou algumas propriedades dos verbos prototípicos.
} 
No tocante à variável traço semântico do sujeito, o traço [-humano] foi o que apresentou a diferença mais perceptível entre o PB e o PE, com 55\% e $71 \%$ de frequência, respectivamente. Não é possível dizer, para o português brasileiro, se este traço está favorecendo ou não a ocorrência da $\mathrm{CV}$, uma vez que apresenta, praticamente, $50 \%$ dos dados para as duas variantes.

Em suma, os fatores linguísticos que favorecem a marcação da CV de terceira pessoa do plural no brasileiro são contextos em que há a presença de acento na desinência, aqueles em que o sujeito preenchido ou nulo apresenta um antecedente com marca de plural, em que o verbo apresenta sujeito antecedente, em que apresentam sujeito com traço [+ humano], sujeito pronome pessoal e os contextos de verbos transitivos e intransitivos.

As variáveis linguísticas que favorecem a marcação de concordância verbal no português europeu são sujeitos com traço [+ humano], verbos com sujeito antecedente, verbos transitivo e intransitivo prototípicos, verbos com sujeito nulo cujo antecedente apresenta marca de plural, contexto em que há ausência de acento na desinência, e sujeitos pronome pessoal. Esta língua apresenta um índice maior de marcação de concordância verbal de terceira pessoa quando comparada ao português falado no Brasil.

É preciso observar mais uma vez que nas duas línguas a CV ocorre com maior frequência. A diferença entre elas não ultrapassa os $20 \%$. As variáveis linguísticas que apresentaram uma diferença significativa em relação à marcação de plural no verbo foram o sujeito pleno composto e o sujeito posposto.

O sujeito posposto parece ser um contexto favorecedor da não marcação de plural no PB; já no PE, embora a percentagem de ocorrência da CV seja baixa, ainda é superior a 50\% de marcação. Já o SN pleno composto parece favorecer a não marcação de plural nas duas línguas, representando $56 \%$ e $60 \%$ para o PB e o PE, respectivamente. É pertinente constatar que, além das análises dos autores, estou observando os contextos linguísticos em que a não marcação de plural no verbo é superior à ocorrência da CV.

Sobre a análise diacrônica, Monguilhott (2009) aponta para indícios de concordância obrigatória com sujeito posposto, no século XIX, para as duas línguas. No século XX, no entanto, o cenário muda e há indícios de um sistema de concordância variável com esse tipo de sujeito, principalmente no PB, que, talvez, não estivesse mais o reconhecendo como sujeito mas sim como objeto. Isto aponta para uma mudança tanto no PB quanto no PE, especialmente no português brasileiro, já que os dados sincrônicos revelam que o sujeito posposto favorece a não ocorrência da CV. 
Rubio (2012) utiliza, para o PB, dados do interior do estado de São Paulo, mais especificamente de São José do Rio Preto, cidade localizada na região noroeste do estado. Para os dados do português europeu, o autor utilizou amostras de regiões diversas, retiradas do Corpus de Referência do Português Contemporâneo (CRPC), do Centro de Linguística da Universidade de Lisboa, mais especificamente do sub-corpus oral espontâneo.

As amostras do português brasileiro apresentaram um percentual de $73 \%$ de concordância verbal, enquanto as do português europeu apresentaram $93,9 \%$ de frequência de marcação. Não obstante essa diferença, a regra de aplicação da CV nas duas línguas é variável.

\begin{tabular}{|l|c|}
\hline Variedade & Ocorrência de CV \\
\hline \hline Português brasileiro & $73 \%$ \\
Português europeu & $93,9 \%$ \\
\hline
\end{tabular}

Tabela 5.2: Concordância sujeito/verbo - PB/PE. Fonte: Rubio (2012).

Os fatores linguísticos relevantes para o PB foram o paralelismo linguístico, que analisa de que modo a presença ou a ausência de marcas de plural no SN sujeito interferem na marcação de plural no verbo; a saliência fônica, o paralelismo discursivo, que busca evidenciar, em uma construção seriada, se a presença de pluralização nos verbos anteriores pode levar a uma maior pluralização dos verbos da oração analisada; o traço semântico do sujeito e a posição do sujeito.

Os resultados de Rubio (2012), em relação a essas variáveis linguísticas, estão de acordo com os apresentados por Monguilhott (2009), na medida em que a anteposição do sujeito, o traço [+] humano, a presença de marca no SN sujeito adjacente ao verbo e um alto grau de saliência fônica favorecem a marcação de plural no verbo.

A posposição do sujeito apresentou-se novamente como favorecedora da não ocorrência de CV no português brasileiro, com uma frequência de não marcação de plural no verbo de $62 \%$.

Os resultados de Rubio (2012) evidenciam que tanto o português brasileiro quanto o português europeu possuem regra de concordância de terceira pessoa do plural variável, embora para o PB a frequência de não concordância seja maior (27\% para o PB e 6,1\% para o PE). O índice da amostra do $\mathrm{PB}$ analisada apresentou marcação de $\mathrm{CV}$ superior ao de outras variedades do PB, como os dados da periferia de São Paulo, por exemplo, que apresenta $71 \%$ de ocorrência de plural na terceira pessoa do plural.

Ao comparar amostras da cidade de São Carlos, em São Paulo, e da cidade de Évora, em Portugal, Monte (2015) aponta para uma percentagem 
maior de concordância em Évora: das 1.440 ocorrências de terceira pessoa do plural, $1.340(93,1 \%)$ apresentam a marca formal de concordância no verbo, enquanto apenas 100 (6,9\%) não possuem a marca de plural nos verbos. Já em São Carlos, das 1.442 ocorrências de terceira pessoa do plural, $686(48,2 \%)$ apresentaram a marca formal de plural no verbo, enquanto 736 $(51,8 \%)$ apresentaram a variante zero de plural nos verbos.

\begin{tabular}{|l|c|}
\hline Variedade & Ocorrência de CV \\
\hline \hline Português brasileiro & $48,2 \%$ \\
Português europeu & $93,1 \%$ \\
\hline
\end{tabular}

Tabela 5.3: Concordância sujeito/verbo - PB/PE. Fonte: Monte (2015).

O trabalho de Monte (2015) difere dos trabalhos de Monguilhott (2009) e Rubio (2012), pois a variante zero é levemente superior em São Carlos, embora seja possível dizer que as duas variantes ocorrem na faixa dos $50 \%$. Além disso, este resultado apresenta, até o momento, a maior dessemelhança entre o PB e o PE, com 48,2\% e 93,1\%, respectivamente, na ocorrência de $C V$, nas duas línguas.

Para os resultados de Monte (2015), a saliência fônica foi a mais relevante para o brasileiro. As marcações de plural aumentam significativamente no nível 2. Enquanto no nível 1, classe 2 (fala/falam), a ocorrência da marca formal de plural é de 30,3\%, na classe 3 do nível 2 (teve/tiveram), a ocorrência salta para 73,4\%.

Neste trabalho, o sujeito posposto mostra-se favorável à não marcação de plural no verbo, especialmente no português brasileiro, com frequência de marcação de plural no verbo de $26,9 \%$ para o $\mathrm{PB}$ e $77,4 \%$ para o PE. Nos três estudos apresentados até o momento, esta tem sido a variável de maior relevância para a não ocorrência da $\mathrm{CV}$.

Dentre as variáveis linguísticas, as mais relevantes, de maneira geral, tanto para o PB quanto para o PE, são a posição do sujeito em relação ao verbo e o traço semântico do sujeito.

Embora os estudos apresentados apontem para variáveis como saliência fônica desempenhando papel importante na marcação da CV, é possível observar que tanto no português brasileiro quanto no português europeu a marcação de plural no verbo ainda corresponde à maioria das ocorrências, com uma diferença, em alguns casos, de, no máximo, 20\% entre as duas línguas.

A variável que parece ter destaque no favorecimento da não marcação de plural no verbo é a posição do sujeito, mais especificamente a posposição, apresentando um índice de não ocorrência de CV superior ao da marcação 
de plural em todos as pesquisas apresentadas até o momento. Apesar de não apresentar um papel proeminente em todos os estudos, o sujeito composto também parece ter significância para a não ocorrência de CV.

No que concerne à variação na concordância verbal, o português europeu apresenta um alto índice de marcação padrão de plural no verbo. Para o português brasileiro, embora o índice de marcação de CV seja mais alto nos trabalhos apresentados, a regra de aplicação da concordância pode ser considerada variável em termos labovianos.

Importante ressaltar que os estudos ora apresentados que comparam as duas línguas, PE e PB, utilizaram dados urbanos do português brasileiro, o que pode justificar os números de aplicação de CV apresentados. Percebe-se também que as variáveis linguísticas que parecem condicionar a marcação de plural no verbo são as mesmas nas duas línguas: anteposição do sujeito, traço [+ humano / + animado] do sujeito e paralelismo formal. Por outro lado, as variáveis que favorecem a não ocorrência de plural no verbo são a posposição do sujeito em relação ao verbo e os verbos inacusativos.

Embora as variáveis sociais não tenham sido exploradas ao longo deste capítulo, a quase totalidade dos estudos é categórica ao afirmar que o grau de escolaridade tem grande influência na marcação de plural verbal, sendo que informantes com maior grau de escolaridade marcam o plural no verbo com maior frequência do que aqueles com menor grau de escolaridade.

\subsection{PB, PE e outras variedades de português}

Para os trabalhos que comparam o português brasileiro, o português europeu e as variedades de português faladas na África, apresento os trabalhos de Brandão \& Vieira (2012), Vieira (2015b) e Mota (2015).

Brandão \& Vieira (2012) analisam a concordância de terceira pessoa do plural no português europeu, no português brasileiro e no português são-tomeense. O quadro geral dos resultados é o seguinte:

\begin{tabular}{|l|c|}
\hline Variedade & Marcação de CV \\
\hline \hline PB (Nova Iguaçu) & $78,1 \%$ \\
PST (São Tomé) & $93,1 \%$ \\
PE (Cacém) & $98,9 \%$ \\
\hline
\end{tabular}

Tabela 5.4: Concordância sujeito/verbo em PB, PE e PST. Fonte: Brandão \& Vieira (2012). 
Nas três línguas, apesar da diferença percentual entre elas, a marcação de plural no verbo apresenta-se como uma regra variável no PB e no PST. Já no PE, diferentemente dos estudos de Monguilhott (2009), Rubio (2012) e Monte (2015), a regra de aplicação da CV apresenta-se como semicategórica.

As variáveis linguísticas relevantes, assim como as demais apresentadas até o momento, foram animacidade, posição do sujeito em relação ao núcleo e a saliência fônica ${ }^{4}$.

Os dados do PB corroboram as análises evidenciadas anteriormente no que concerne à posposição do sujeito como favorecedora da não marcação de plural no verbo, com 47,6\% de marcação de plural. Para o português falado em São Tomé essa variável não parece ter tanta relevância, pois a frequência de ocorrência de CV é de 78,6\%.

Os resultados do trabalho de Brandão e Vieira estão em consonância com os de outros trabalhos sobre o tema em que as variáveis traço [+humano] do sujeito e a anteposição do sujeito favorecem a marcação da CV, além, é claro, da saliência fônica.

O PST apresentou uma frequência maior de marcação de concordância verbal se comparado ao PB. Já para o PE, as autoras observam que o que elas chamam de suposta falta de concordância está concentrada em contextos linguísticos diferentes dos verificados no português falado no Brasil e do português de São Tomé e que a aplicação de CV não pode ser considerada uma regra variável para essa língua e sim uma regra semicategórica.

Em outro estudo sobre essas três variedades do português, Vieira (2015b) faz um balanço a respeito dos três anos do projeto Estudo comparado dos padrões de concordância em variedades africanas, brasileiras e europeias do Português da ALFAL (Associação de Linguística e Filologia da América Latina). Os dados que fundamentam as análises do projeto são os mais diversos. Em relação ao PB foram focalizados dados de regiões metropolitanas, já para os dados do português europeu foram consideradas as regiões de Oeiras e Cacém, na região metropolitana de Lisboa, e Funchal na Ilha da Madeira. Os dados de São Tomé (PST), por sua vez, são entrevistas com falantes de português como língua materna.

Sobre os resultados gerais, a autora apresenta os resultados de Vieira \& Bazenga (2013) que são os mesmos apresentados em Vieira \& Bazenga (2015). Em números absolutos há um total de 1.467 dados para Oeiras; 1.185 para Cacém; 914 para Funchal; 1.395 para Copacabana; 1.365 para Nova Iguaçu e 737 dados para São Tomé:

\footnotetext{
${ }^{4}$ As autoras não apresentam os resultados das variáveis linguísticas para o português europeu.
} 


\begin{tabular}{|l|c|}
\hline Amostra & Presença de Plural \\
\hline \hline Oeiras & $99,1 \%$ \\
Cacém & $99,2 \%$ \\
Funchal & $94,7 \%$ \\
São Tomé & $92,1 \%$ \\
Copacabana & $88,1 \%$ \\
Nova Iguaçu & $78,8 \%$ \\
\hline
\end{tabular}

Tabela 5.5: Concordância sujeito/verbo em PB, PE e PST. Fonte: Vieira (2015b).

Sobre a variável que tem se mostrado, até o momento, mais relevante na não marcação de plural, a posposição do sujeito, percebe-se que ela interfere nos dados de Nova Iguaçu (PB), com 46,2\% de marcação de plural, e em Funchal (PE), com 47,2\% de ocorrência de CV. Nas demais, aparenta não ter relevância, uma vez que a frequência de marcação se mantém acima dos $70 \%$. O que parece então é que, talvez, não seria apenas uma questão de condicionamento linguístico, pois, se assim fosse, a variedade de Copacabana deveria apresentar maior percentagem de não marcação de plural no verbo com sujeito posposto, porém, apresenta uma frequência de $84,1 \%$ de $C V$.

Para a variável de São Tomé o fator do bi/multilinguismo também foi analisado. Haveria então três níveis de frequência de uso de uma língua crioula, de acordo com Brandão (2011, 2013): para os que só utilizam o português e dominam ou não uma língua crioula, seria zero ou baixa frequência; para os que usam o português e uma ou mais línguas crioulas, média frequência, e para os que utilizam a língua crioula mais vezes, alta frequência.

Para os primeiros, ou seja, que possuem zero ou baixa frequência na utilização de uma língua crioula, a ocorrência de marca de plural foi de 92,4\%; para os de média frequência, a ocorrência de plural foi de $90,2 \%$; já os que têm alta frequência de utilização de uma língua crioula apresentaram um total de 79,8\% de marcação de CV.

A análise do português europeu evidenciou que os contextos que favorecem a não marcação de plural no verbo são sujeitos de traço [-animado] $(68,1 \%)$; sujeito posposto $(54,5 \%)$, em especial os intransitivos e os inacusativos; sujeito representado pelo relativo que (49,8\%); verbo com baixa saliência fônica, dentre os quais uma boa parte são copulativos.

Os dados do PST também revelam uma regra variável de aplicação da $\mathrm{CV}$, apresentando porcentagem de marcação superior a $90 \%$. As variáveis linguísticas que interferem na ocorrência da concordância verbal são as 
mesmas que no PB e no PE, com maior atenção para a posição do sujeito e o traço semântico do sujeito.

Mota (2015) realiza um estudo sobre as variedades de português faladas em Luanda (PL), Angola, e Cabo Verde. No português falado em Luanda observa-se um baixo índice de não marcação de concordância do plural, com 1,53\% de não marcação para falantes de português como L1 (primeira língua) e 4,9\% de não marcação para falantes de português como L2 (segunda língua). Esses falantes de português como L2 são bi ou multilíngues de línguas bantas.

\begin{tabular}{|l|c|}
\hline Variedade & Frequência de CV \\
\hline \hline Lisboa (PE) & $99,1 \%$ \\
Cacém (PE) & $99,2 \%$ \\
Funchal (PE) & $94,7 \%$ \\
PST & $92,1 \%$ \\
Copacabana (PB) & $88,1 \%$ \\
Nova Iguaçu (PB) & $78,2 \%$ \\
Luanda & $97 \%$ \\
\hline
\end{tabular}

Tabela 5.6: Concordância sujeito/verbo em PE, PST, PB e PL. Fonte: Vieira (2015b).

Nesse sentido, a marcação de plural no verbo pode ser considerada uma regra semicategórica no português falado em Portugal e em Luanda.

Os casos de não marcação de plural verbal são em número maior entre os falantes de português como L2, seguidos de falantes bi/multilíngues ou aqueles que possuem conhecimento passivo de línguas bantas, no entanto, o índice de marcação da CV ainda é alto, com 98,4\% de marcação de plural para falantes de português como L1 e 95,1\% para falantes de português como L2, configurando-se ainda como uma regra semicategórica. As variáveis pertinentes para o português falado em Luanda foram, além do bi/multilinguismo, a saliência fônica, a posição do sujeito e os verbos inacusativos, copulativos, existenciais.

Para o português falado em Cabo Verde, todos os falantes são bilíngues, logo, o fator português como L2 não se aplica nesta amostra de dados. Os resultados evidenciam uma frequência de $0,28 \%$ de não ocorrência de plural nos verbos de terceira pessoa do plural. A autora não explora muito os resultados de Cabo Verde, apenas atribui o baixo índice à escolarização dos informantes, todos professores de português. 


\subsection{Português de Moçambique e português de An- gola}

Não há, ou não tenho conhecimento de que exista, para o português de Moçambique (PM), estudos sobre a concordância verbal, no entanto, parece haver, assim como nas outras variedades de português, uma variação na CV. Grande parte dos estudos sobre a variação na marcação de número do português falado em Moçambique o faz no âmbito do sintagma nominal. Mesmo parecendo ser a concordância de plural no verbo um fenômeno variável no PM, não há como precisar a frequência dessa variação, nem se é uma regra variável ou semicategórica, uma vez que, conforme já mencionado, não tenho conhecimento de estudos quantitativos sobre o tema.

Partindo do fato de que há uma ausência de estudos sobre a CV no português falado em Moçambique e devido à pertinência do estudo sobre este tema nesta língua para a discussão sobre a concordância verbal de maneira geral, farei, a partir de dados retirados de diferentes estudos, uma breve descrição sobre a concordância verbal nessa língua. Não será possível, contudo, fazer uma análise quantitativa dos dados, apenas uma breve descrição dos contextos existentes nos dados aos quais tive acesso.

No PM, ocorre, além da marcação canônica de plural no sujeito e no verbo, a marcação do plural apenas no sujeito, como é possível verificar nos dados de (19) a (23), o que ocorre também em PB, PE e PST:

$$
\text { Ultimamente, OS CASAMENTOS não DURA. }
$$

(Gonçalves, 2001:985)

(20) Às vezes OS PROFESSORES CHEGA àquela hora certa ou atrasa.

(21) OS FILHOS de agora PARECE que tira dinheiro.

(Gonçalves \& Stroud, 1998: 125)

(22) HÁ MULHERES que PASSA a vida dedicada só a viver solteira.

(23) Ele vai para essas escolas para receber ESSES ALUNOS que É mandado voltar.

(Gonçalves \& Stroud, 1998: 126)

Observa-se, nos dados de (20) a (23), que o sujeito possui marca de plural no último elemento e, mesmo para sujeitos adjacentes ao verbo, como é o caso de (20), o verbo não recebe a marcação de plural.

A variação na $\mathrm{CV}$ ocorre mesmo quando o sujeito é composto e plural, como em (24): 
BENS NECESSÁRIOS E BÁSICOS para um indivíduo adquirir ESTÁ muito além das suas capacidades

(Bavo, 2015: 47)

Para o dado (24) seria possível pensar que a distância entre o sujeito e o verbo facilitaria a não marcação de plural no verbo, porém, os resultados do estudo de Rubio (2012) mostram que esta distância não parece interferir na marcação de plural no verbo. Importante observar que se trata de um verbo de alta saliência fônica.

Nota-se também a marcação do verbo no plural com sujeitos coletivos singulares, atestada pelos dados (25) e (26). Interessante notar que grande parte dos dados em que o verbo recebe a marcação de plural com sujeitos coletivos singulares ocorre quando da presença do pronome gente, independentemente se este refere-se à primeira pessoa do plural (27) ou ao nome coletivo gente.

(25) Não sei se há uma ORGANIZAÇÃO qualquer deles que POSSAM fazer valer a sua voz...

(Gonçalves \& Stroud, 1998: 100)

(26) MUITA GENTE já DEIXARAM as igrejas, foram para ali.

(27) A GENTE ESTAMOS juntos

(Gonçalves \& Stroud, 1998: 100-126)

Na sequência de dados (25) a (27), os sujeitos coletivos singulares podem estar sendo interpretados como plurais, o que pode justificar a ocorrência dos verbos no plural ${ }^{5}$. Observem-se os dados a seguir:

(28) É verdade, não HAVIAM ESSES CASOS.

(Gonçalves \& Stroud, 1998: 127)

(29) Só eram os dois que eram amigos O RESTO ERAM bandidos

(Gonçalves \& Stroud, 2000: 202)

Em (28) há a marcação de plural no verbo haver para que este concorde morfologicamente com o sujeito posposto plural esses casos, contudo, a flexão, para este verbo, de acordo com a gramática normativa, não seria necessária.

Em (29) o que ocorre é o verbo marcado no plural com um sujeito singular, ao invés de concordar com o sujeito o resto, que inclusive está adjacente ao verbo. $\mathrm{O}$ verbo realiza uma espécie de concordância com os

\footnotetext{
tulo 8 .

${ }^{5}$ Explorarei a ocorrência de verbos plurais com sujeitos coletivos singulares no capí-
} 
verbos anteriores da oração, que foram apresentados no plural, seguindo um paralelismo discursivo.

Há ainda um fenômeno interessante no PM que parece também ser atestado no PE e no PB: a ocorrência de infinitivos flexionados, vista na sequência de (30) a $(33)^{6}$ :

(30) OS PROFESSORES não conseguem DAREM aulas.

(31) Deviam AS MOÇAS FAZEREM o planeamento.

(32) AS PESSOAS lá têm um horário para PODEREM se SEPARAREM da cidade

(Stroud \& Perpétua, 1997: 62)

(33) UM HOMEM de lá da terra com mulheres daqui COSTUMAM VIVEREM bem.

(Gonçalves \& Stroud, 1998: 127)

No português falado em Angola também é possível notar alguma variação na marcação de plural no verbo. Assim como no PM, a variação na marcação de número é estudada de modo mais amplo no domínio nominal, contudo, alguns autores apresentam a variação na marcação de plural no verbo (Adriano, 2014; Bento, 2010, entre outros). O estudo de Mota (2015) aponta para a marcação de concordância verbal em Luanda como uma regra semicategórica, no entanto, a ausência de mais estudos quantitativos em Angola sobre este tema impede de confirmar se tal regra é semicategórica apenas para o português falado em Luanda, ou ainda, somente para as regiões estudadas por Mota (2015).

Nos dados (34), (35) e (36) verifica-se a marcação de plural apenas no sujeito, enquanto o verbo não recebe qualquer marca de número plural, contextos facilmente encontrados no PB e no PST.

(34) apelo a TODOS ANGOLANOS para que POSSA exercer este direito de cidadania para que possa votar de coração limpo e porque a democracia é consolidada com momentos como estes

(Adriano, 2014: 217-18)

depois de VOCÊS APRENDER falar umbundo começa já a vos dividir

(Figueiredo \& Oliveira, 2013: 134)

\footnotetext{
${ }^{6}$ Este fenômeno não é o foco da presente tese. Em vista disso, para mais detalhes sobre os infinitivos flexionados, ver Raposo (1987), Miller (2002), Modesto (2010, 2011, 2016), entre outros.
} 

Quatro de Fevereiro que foi o início da luta armada

(Chavagne, 2005: anexo: 44)

Sujeitos compostos também apresentam variação na CV ((37) e (38)). É possível afirmar que estes sujeitos estão sendo entendidos como singulares. Os estudos de Monguilhott (2009) e Rubio (2012) apontam para esta variável como favorecendo a não marcação de plural no verbo para o português brasileiro.

A ÍNDOLE E A POSTURA ética se DESENVOLVE muito vote no Partido para que A SUA VIDA E A SUA FAMÍLIA MUDE nós levaremos as suas preocupações ao Parlamento angolano

(Adriano, 2014: 242)

A variação na marcação de plural também ocorre com sujeitos coletivos singulares. Diferentemente do português falado em Moçambique, essa variação é mais ampla, não restrita apenas ao pronome gente $(41)^{7}$. Importante notar que a variação com este pronome ocorre, igualmente, na primeira pessoa do plural (40) e com o nome coletivo gente (39):

(39) o facto de se terem colocado as listas nas escola e nos locais de voto está facilitar muita GENTE consultar onde VÃO votar no dia da votação

(Adriano, 2014:269)

(40) depois da GENTE CUMPRIRMOS este dever a família provavelmente estará satisfeita

(Adriano, 2014: 267)

(41) É que pronto AQUELE PESSOAL mesmo FALAVAM umbundu e então prontos, lidava com esse pessoal, conversava, e não sê quê e tive necessidade de aprender

(Chavagne, 2005: anexo: 148)

Nesses exemplos (de (39) a (41)), assim como apontado para o português de Moçambique, o sujeito coletivo singular está sendo interpretado como plural, o que leva a marcação de plural no verbo.

Conforme visto nos estudos apresentados no decorrer deste capítulo, sujeitos pospostos favorecem a não marcação de plural no verbo, conforme dados a seguir:

\footnotetext{
${ }^{7}$ Discutirei os dados do português de Angola pertinentes a esta variação no capítulo 8, quando tratar dos sujeitos coletivos nas comunidades maranhenses.
} 
Português de Moçambique e português de Angola

já COMEÇOU OS TRABALHOS para darmos início à construção das novas centralidades de Mbanza Congo e do Soyo

sabemos que está em fase de elaboração final o Plano Reitor das infra-estruturas que abarcará um horizonte temporal de quinze anos por este facto GANHA muito mais importância AS DECISÕES que hoje tomaremos

(Adriano, 2014: 232)

E, de modo interessante, sujeitos singulares apresentam verbos marcados no plural:

(44) NOSSO FILHO que ainda APRENDERAM um bocado connosco

(Figueiredo \& Oliveira, 2013: 169)

(45) Eu apoio O PROGRAMA de governo do Partido porque NELE CONSTAM a solução da minhas preocupações

(Adriano, 2014: 186)

Dados como os (44) e (45), em que o sujeito é singular e o verbo ocorre no plural, também são encontrados nas comunidades quilombolas alcantarenses. Isso pode enfatizar ainda mais o grau de variabilidade dessa marcação, ou seja, a variação se dá tanto com sujeitos plurais e verbos singulares quanto com sujeitos singulares e verbos plurais.

Tanto no PM quanto no PA há poucos estudos sobre a variação na ocorrência da concordância verbal. O PA apresenta o estudo de Mota (2015), em que a marcação de plural no verbo é apresentada como uma regra semicategórica. No PM parece não haver estudos sobre a variação na CV. Com base em dados retirados de diferentes autores, descrevi brevemente os contextos de ocorrência de variação na marcação de plural verbal de terceira pessoa nas duas línguas.

Diante dos dados disponíveis, não foi possível realizar uma análise quantitativa, tampouco estes dados podem representar todos os contextos de variação na marcação de $\mathrm{CV}$. Considerando que este é um fenômeno relevante para as discussões sobre o contato, vale a pena apontar para a necessidade de estudos sobre ele nas variedades africanas do português a fim de verificar se, de fato, em Angola, a ocorrência de plural no verbo pode ser considerada como uma regra semicategórica e, ainda, verificar qual a amplitude deste fenômeno no português falado em Moçambique. 


\subsection{A CV nas variedades urbanas do português brasileiro}

Para os estudos que analisam as variedades urbanas do português brasileiro, trago os trabalhos de Silva \& Santos (2014), de Araujo (2014) e de Welchen (2015).

Silva \& Santos (2014) investigam o fenômeno da concordância da terceira pessoa do plural no chamado português popular ${ }^{8}$ falado em Vitória da Conquista, no estado da Bahia, e apresentam 17,2\% de aplicação de regra de concordância nos dados analisados. Dos 1.055 contextos de terceira pessoa do plural, 181 apresentaram a ocorrência de CV e 874 (82,8\%) não apresentaram marcas de plural no verbo.

Estes resultados diferem dos estudos apresentados até então no presente capítulo para o brasileiro, que mostravam um percentual superior na marcação de plural no verbo, se comparado ao de não marcação.

Apesar da diferença apresentada nos resultados quantitativos, a influência da saliência fônica se mostra igualmente pertinente neste estudo, apresentando $73,6 \%$ de frequência de marcação para posição acentuada para as ocorrências de $\mathrm{CV}$.

Eles relacionam a baixa ocorrência de marcação de $\mathrm{CV}$ ao distanciamento entre as normas popular e culta, evidenciando uma realidade linguística e social bipolarizada no Brasil.

Araujo (2014) $)^{9}$ analisa a concordância verbal nas chamadas normas popular, considerando rural e urbana, e culta, urbana em Feira de Santana, Bahia.

Dos dados coletados, 1.969 ocorrências apresentaram o contexto de terceira pessoa do plural, 659 para a norma culta e 1.310 para a norma popular. Para a norma culta, $619(93,9 \%)$ apresentaram marca de plural no verbo, já para a norma popular, o total de ocorrências que apresentou marca de plural no verbo foi de $24,5 \%$ (321), com 989 ocorrências $(75,5 \%)$ sem qualquer marcação de CV.

\footnotetext{
${ }^{8}$ Falado por pessoas residentes nas áreas periféricas de Vitória da Conquista e com "formação escolar precária".

${ }^{9} \mathrm{~A}$ autora considera como variantes padrão aquelas em que se observam marcas de plural, mesmo com alterações morfofonêmicas do tipo pararo e construíro.
} 
A CV nas variedades urbanas do português brasileiro

\begin{tabular}{|l|c|}
\hline Norma & Frequência de CV \\
\hline \hline Norma culta & $93,2 \%$ \\
Norma popular & $25,5 \%$ \\
\hline
\end{tabular}

Tabela 5.7: Concordância sujeito/verbo - Normas popular e culta (BA). Fonte: Araujo (2014).

Essas percentagens evidenciam uma considerável diferença de ocorrência de plural no verbo em relação à norma popular e à norma culta, com maior índice de marcação de plural verbal na fala culta.

$\mathrm{Na}$ fala culta, o sujeito posposto aparece novamente como favorecedor da não marcação de plural no verbo, corroborando outras pesquisas já realizadas sobre o PB.

Ainda sobre a fala culta, diferentemente do esperado, alguns contextos que não apresentaram a CV são apontados como favorecedores da marcação de plural, como, por exemplo, o sujeito anteposto ao verbo, que apresentou 6 casos de não marcação e o sujeito referencial não realizado, com 7 dados.

De modo interessante, distintamente de outros trabalhos sobre o tema, a variável saliência fônica não se mostrou relevante em termos estatísticos para a fala culta de Feira de Santana. De maneira mais detalhada, a autora não evidenciou em seus dados uma relação entre o uso da variante padrão e maior diferença fônica entre as formas no singular e no plural do verbo.

Outra variável comumente apontada como relevante, mas que não se mostrou tão pertinente, foi a característica semântica do sujeito, uma vez que o índice de aplicação da CV foi alto, independentemente do traço do sujeito ser [+humano] (94,8\% de CV) ou [- humano] (91,1\% de CV).

Já para a norma popular, a variável saliência fônica mostrou-se pertinente, corroborando a afirmação de que, quanto maior a diferença entre as formas singular e plural do verbo, maior a probabilidade de ocorrência de marcas de plural no verbo. Para essa norma a frequência de não marcação de CV foi de $75,5 \%$.

Na norma popular, diversamente dos dados apresentados para o português brasileiro nos estudos anteriores, a marcação de plural verbal não chega a $50 \%$ dos dados em nenhuma das variáveis linguísticas. Evidenciase, desta forma, que a divisão entre normas culta e popular é relevante para entender a variação na marcação de plural no verbo na terceira pessoa.

Observa-se que a variável posição e realização do sujeito é relevante para ambas as normas, com a posposição do sujeito aparecendo mais uma vez como a maior favorecedora da não ocorrência de $C V$. No entanto, variáveis linguísticas pertinentes em diversos estudos sobre CV mostraramse relevantes apenas para a norma popular, como a saliência fônica e o 
traço semântico do sujeito, por exemplo. A autora observa que a variável saliência fônica interferiria apenas nas variedades mais afetadas pelo contato. Os resultados da norma popular vão ao encontro dos demais estudos realizados sobre a variação da marcação do plural no PB, em especial no que se refere às duas variáveis anteriormente citadas.

Não obstante, é saliente a diferença entre a ocorrência da CV nas duas normas, em que a norma culta apresenta um índice muito elevado de marcação de plural no verbo (93,9\%), ao passo que, na norma popular, esse índice é relativamente baixo, com $24,5 \%$ de frequência.

Os dados de Pelotas, no Rio Grande do Sul, analisados por Welchen (2015) mostram uma presença maior de concordância verbal: dos 5.263 contextos propícios para a aplicação da regra de concordância de terceira pessoa do plural, $4.317(82 \%)$ apresentaram a marca e 945 (18\%) não. A autora aponta também para um indício de aquisição da regra de CV por parte dos falantes.

Na mesma linha de outros trabalhos, a saliência fônica mostrou-se significativa para a ocorrência de $\mathrm{CV}$, em que as formas mais salientes favorecem a ocorrência de marcas de plural no verbo, do mesmo modo que a posição do sujeito, na qual a anteposição favorece a aplicação da $\mathrm{CV}$, com uma frequência de $86 \%$. A posposição, no sentido inverso e em consonância com as demais análises, favorece a não ocorrência da marcação de plural do verbo, apresentando a percentagem mais baixa de ocorrência de $C V, 50 \%$.

\subsection{A CV em variedades não urbanas do portu- guês brasileiro}

Para as variedades não urbanas do $\mathrm{PB}$, especificamente de comunidades quilombolas e rurais cujos resultados serão pertinentes para a discussão dos dados das comunidades alcantarenses, os trabalhos apresentados serão os de Silva (2005), de Almeida (2006a), de Lucchesi et al. (2009) e de Lima (2014).

Silva (2005) investiga a comunidade quilombola de Cinzento, localizada em Planalto, na Bahia; o povoado de Morrinhos, que fica na zona rural do município de Poções; e o próprio município de Poções, mas na área urbana.

De maneira semelhante aos resultados da fala popular de Feira de Santana e Vitória da Conquista, os dados de áreas não urbanas apresentam um índice de não ocorrência de plural no verbo superior à de plural. Nesse sentido, a divisão entre dados de zonas urbanas e não urbanas é pertinente 
para a análise da marcação de concordância verbal da terceira pessoa do plural.

Os dados estão divididos nas três comunidades conforme segue: em Cinzento há um total de 927 ocorrências de contextos de terceira pessoa do plural; em Morrinhos o total de ocorrências é de 602 dados e em Poções, 571 dados. É possível verificar que a comunidade quilombola de Cinzento apresenta o menor índice de frequência da $\mathrm{CV}$, enquanto a área urbana de Poções apresenta o maior índice de frequência.

\begin{tabular}{|l|c|c|}
\hline Comunidade & Quantidade & Percentagem \\
\hline \hline Cinzento & 117 & $13 \%$ \\
Morrinhos & 103 & $17 \%$ \\
Poções & 147 & $26 \%$ \\
\hline
\end{tabular}

Tabela 5.8: Concordância verbal em Cinzento, Morrinhos e Poções/BA. Fonte: Silva (2005).

Os resultados de Silva (2005) não são diferentes dos demais estudos em relação à variável posição do sujeito. Mais uma vez a posposição do sujeito aparece como o fator que mais favorece a não ocorrência da CV, com 92\% de não marcação de plural no verbo.

Sem fugir à regra, o traço [+ humano] favorece a ocorrência de marca formal de plural no verbo (19\% de CV) e o traço [- humano] a desfavorece ( $9 \%$ de CV). Os resultados da variável saliência fônica também são conforme o esperado, quanto menor a saliência fônica menor a ocorrência de CV (3\%) e quanto maior a saliência, maior a ocorrência (37\%).

Dentre as variáveis linguísticas, a que se mostrou mais favorável à aplicação da regra de concordância verbal foi a forma de indicação lexical do plural, com $70 \%$ de ocorrência de CV.

Esta variável linguística, no entanto, não é controlada em todos os estudos sobre a variação na CV. Há casos nos quais alguns dos tipos de indicação de plural são amalgamados, como em Araujo (2014), em que as indicações de plural e mórfica são consideradas juntas. Silva \& Santos (2014) controlam essas mesmas variáveis e, ao se compararem os dois resultados, observa-se que a indicação de plural através de numeral parece ser a que mais favorece a não marcação no verbo. Diante do fato de essa variável linguística não estar presente em todos os estudos, não é possível estabelecer com clareza o papel que a forma de indicação do plural no sujeito exerce na marcação de plural no verbo.

Almeida (2006a) analisa os dados da comunidade de São Miguel dos Pretos, localizada no município de Restinga Seca, no Rio Grande do Sul. 
A autora considera dados do tipo confirmaro, andaro como marcação não padrão.

Dos 1.044 dados referentes à concordância verbal de terceira pessoa, 847 (81\%) apresentaram a CV e 197 (19\%) não apresentaram marca formal de plural no verbo. Os resultados afastam-se de outros estudos de fala não urbana, em que a ocorrência de CV chega, em alguns casos, a 16\% do total dos dados, como em Helvécia (BA).

Igualmente, a posição do sujeito também reflete resultados já evidenciados em outros trabalhos, em que a anteposição do sujeito favorece a ocorrência de desinência plural nos verbos (83\%), ao passo que a posposição do sujeito, em consonância com os demais estudos, desfavorece a marcação de plural (51\%).

Em relação à diferença do percentual de ocorrência de CV da comunidade de São Miguel dos Pretos em relação às comunidades da Bahia, Rio de Contas, Helvécia e Cinzento, Almeida atribui às características sociais e históricas da comunidade do Rio Grande do Sul, que não ficou isolada do contato com outras fazendas e com a zona urbana de Restinga Seca, o que teria facilitado o acesso às variedades de língua com um índice de concordância verbal mais alto.

Lucchesi et al. (2009) chamam a atenção para o fato de existir um continuum no tocante à utilização do morfema de número no português brasileiro que vai desde a norma urbana culta até as comunidades afrobrasileiras. Este contínuo constituiria uma evidência empírica de como o contato entre diferentes línguas na época da colonização afetou diversas variedades do português brasileiro.

As variedades ditas populares, com sua formação mais ligada ao contato de línguas, apresentariam as menores frequências de uso das marcas formais de plural, ao passo que as variedades urbanas ditas cultas ou semicultas, que foram afetadas indiretamente pelo contato, teriam os maiores índices de aplicação da regra de CV.

\begin{tabular}{|l|c|c|}
\hline Variedade & Autores & CV \\
\hline \hline Interior da Bahia (CHBBN) & Lucchesi et al. (2009) & $16 \%$ \\
RJ (fala não urbana) & Vieira (1997) & $38 \%$ \\
Rio de Janeiro (analfabetos) & Naro (1981) & $48 \%$ \\
Rio de Janeiro (escolarizados) & Scherre \& Naro (1997) & $73 \%$ \\
Florianópolis (escolarizados) & Monguilhott \& Coelho (2002) & $79 \%$ \\
RJ (norma urbana culta) & Graciosa (1991) & $94 \%$ \\
\hline
\end{tabular}

Tabela 5.9: Continuum de marcação da concordância verbal em diferentes variedades do português brasileiro. Fonte: Lucchesi et al. (2009). 
Enquanto nas comunidades afro-brasileiras do interior da Bahia há um nível elevado de variação na marcação de $\mathrm{CV}$, na fala urbana culta do Rio de Janeiro a ocorrência de marcas formais de plural é quase semicategórica. Logo, o contato de línguas, mais forte nessas comunidades afro-brasileiras, seria o responsável pelo alto índice de variação da CV.

O trabalho de Lucchesi et al. (2009) fez uso de dados das comunidades de Cinzento (C), no Município de Planalto; Helvécia (H), no Município de Nova Viçosa; e das comunidades geminadas de Barra (B) e Bananal (BN), no Município de Rio de Contas, todas no interior da Bahia. Das 1.706 formas verbais ligadas à terceira pessoa do plural, 273 apresentaram a aplicação da regra de concordância, o que corresponde a 16\% do total.

Entre as comunidades, a de Cinzento, de forma semelhante ao resultado de Silva (2005), apresentou o menor índice de concordância (13\%) e a de Rio de Contas o maior índice (24\%).

Os resultados a respeito da saliência fônica não fogem à regra no estudo em questão: verbos com nível maior de saliência fônica apresentaram maior índice de concordância (31\%), enquanto os verbos com menor saliência fônica apresentaram o menor índice de marcação de CV (6\%).

A posposição do sujeito novamente favorece a não marcação de plural, com $89 \%$ de não ocorrência de $\mathrm{CV}$. Em consonância com outros trabalhos, o traço [+ humano] favorece a marcação de plural no verbo, com $17 \%$ de frequência, já o traço [- humano] desfavorece a ocorrência de CV, com 10\% de frequência.

Diante dos dados e das variáveis sociais, Lucchesi et al. (2009) apontam para o que eles chamam de uma tendência para a aquisição da regra de concordância, o que contraria as hipóteses que afirmam estar, o português brasileiro, perdendo essas marcas (Naro, 1981; Naro \& Scherre, 2007).

Lima (2014) explora o léxico que ela considera específico da comunidade de Caiana dos Crioulos, localizada na Paraíba. Não obstante, analisa outros fenômenos que ocorrem na fala dessa comunidade, a exemplo de alguns fenômenos fonéticos tais como a apócope, o rotacismo, a monotongação, a perda da nasalização final, entre outros, e alguns fenômenos morfossintáticos como a concordância nominal, a estrutura de negação, os pronomes pessoais, o grau diminutivo e a concordância verbal.

Embora apresentados de maneira sucinta, Lima analisa 186 casos de variação na concordância verbal debruçando-se sobre as variáveis como a posição do sujeito e a natureza da oposição singular/plural.

Tanto com sujeito anteposto ao verbo quanto com o sujeito posposto ao verbo, o índice de ausência de concordância é superior ao de presença de concordância, com 54 ocorrências (83\%) sem CV e 11 ocorrências (17\%) com concordância para os sujeitos antes do verbo, 17 ocorrências sem 
concordância verbal e nenhuma com a presença de concordância para os sujeitos pospostos ao verbo. Mais uma vez a posposição do sujeito aparece como altamente favorecedora da não marcação de plural no verbo.

A autora traz à tona a citação de Lucchesi segundo a qual, para os dados do português afro-brasileiro, a posição do sujeito não é tão relevante quanto para os dados do português urbano, por exemplo, pois a frequência de aplicação da regra de concordância entre o sujeito antes do verbo e o sujeito após o verbo não ultrapassa três pontos percentuais. No entanto, ao longo deste capítulo foi possível observar que a posição do verbo é relevante para a marcação de plural verbal, com a posposição do sujeito emergindo como altamente favorecedora da não marcação de plural para praticamente todos os dados do português brasileiro apresentados, com exceção da amostra de Copacabana (Vieira, 2015b), tanto na fala urbana quanto nas falas urbana culta, popular, rural e quilombola.

\subsection{Considerações do capítulo}

Os estudos sobre a variação na $\mathrm{CV}$ analisam, além das variáveis sociais, que não foram exploradas neste capítulo, variáveis linguísticas que poderiam favorecer ou não a marcação de plural no verbo de terceira pessoa. Embora uma análise ou outra possa diferir quanto às variáveis escolhidas, algumas estão sempre presentes, como, por exemplo, a saliência fônica e a posição do sujeito em relação ao verbo.

Observa-se que, independentemente da variedade estudada, as variáveis linguísticas mais relevantes para a ocorrência de marca formal de plural no verbo são a saliência fônica, a posição do sujeito e o traço semântico do sujeito. Essas três variáveis revelaram-se, em todos os trabalhos, as que mais condicionam ou não a aplicação da CV. Quanto mais saliência fônica possui o verbo, ou seja, quanto maior a diferença entre as formas singular e plural, maior a probabilidade de ocorrer a marcação de plural no verbo. Da mesma forma, a anteposição do sujeito bem como a presença de marca de plural no SN sujeito favorecem a ocorrência de plural no verbo.

A despeito do fato de Lucchesi afirmar que a variável posição do sujeito não é relevante para as variedades do português afro-brasileiro, ainda assim nota-se um favorecimento da anteposição do sujeito para a ocorrência de marca de plural no verbo.

O traço [+ humano] também favorece a aplicação da regra de concordância. De outro modo, o oposto dessas variáveis, isto é, uma baixa saliência fônica, a posposição do sujeito e o traço [- humano] são os contextos que mais desfavorecem a ocorrência de concordância verbal. Os diferentes tra- 
balhos são unânimes quanto a essa conclusão, o que difere de um trabalho a outro é a frequência de ocorrência da marcação de plural.

Outras variáveis são importantes para a aplicação da regra de marcação de plural, como o tipo de verbo, por exemplo, no entanto, as mais salientes para as diferentes análises foram as três citadas anteriormente.

Importante observar que os trabalhos não consideram sempre as mesmas variáveis linguísticas. Enquanto para alguns autores a distância entre o sujeito e o verbo é considerada relevante (Rubio, 2012), para outros essa não é uma informação pertinente. A conjugação verbal é importante para algumas análises (Almeida, 2006a) e não é considerada em outras.

Embora os estudos sobre a concordância verbal e, de modo mais específico, a variação no uso da concordância verbal sejam muitos, com uma tradição de mais de trinta anos de análises e tentativas de relacionar a variação encontrada no português brasileiro à frequência de uso da CV em outras variedades do português, como o português europeu - em maior número - e o português falado na África, é possível observar que os estudos sobre essa variação em comunidades quilombolas são poucos.

Se considerarmos que esse fenômeno está no centro das discussões sobre as origens do português brasileiro e que as comunidades quilombolas seriam excelentes fontes de dados para investigar essa origem, dado que uma boa parte delas manteve-se isolada do contato com as áreas urbanas, seria de se esperar que estudos sobre tal fenômeno nessas comunidades fossem em maior número.

A despeito das variáveis linguísticas, o que, de fato, evidencia uma diferença entre a ocorrência e a ausência de plural no verbo é a norma analisada. Ou seja, a norma não urbana apresentou uma percentagem de não ocorrência da CV superior à de ocorrência da concordância verbal, ao passo que a norma urbana, por sua vez, em especial a culta, apresenta percentagens de marcação de plural superiores às de não marcação de plural verbal.

Diante disso, para além das variedades linguísticas, que apresentam resultados similares nos diferentes estudos, a primeira distinção a ser feita seria entre as normas urbanas e não urbanas, para investigar por que haveria maior presença de marcação de plural na terceira pessoa na primeira norma e não na última.

Os diferentes estudos que analisam as normas não urbanas atribuem esta diferença ao contato linguístico com línguas africanas, o que teria influenciado esta não marcação (Silva, 2005; Lucchesi et al., 2009, entre outros), e à baixa escolaridade, geralmente existente nas zonas não urbanas. Lucchesi et al. (2009) apontam para um contínuo de marcação no verbo de terceira 
pessoa do plural que vai das zonas rurais, em especial as comunidades quilombolas, até as zonas urbanas, principalmente a fala culta.

Abaixo apresento uma tabela, adaptada de Rubio (2012) e atualizada com trabalhos mais recentes, dos diferentes estudos sobre a marcação de terceira pessoa do plural em variedades do português brasileiro, que evidencia a ocorrência de marcação de plural na terceira pessoa em diferentes regiões brasileiras:

\begin{tabular}{|l|c|c|}
\hline Variedade & autor & Ocorrência de CV \\
\hline \hline Comunidades CHBBN (BA) & (Silva, 2005) & $16 \%$ \\
Caiana dos Crioulos (PB) & (Lima, 2014) & $17 \%$ \\
Vitória da Conquista (BA) & (Silva \& Santos, 2014) & $17,2 \%$ \\
Feira de Santana (popular) & (Araujo, 2014) & $24,5 \%$ \\
São Carlos (SP) & (Monte, 2007) & $25 \%$ \\
Periferia de São Paulo & (Rodrigues, 1987) & $29 \%$ \\
Pará (analfabetos) & (Nina, 1980) & $29 \%$ \\
Vale do Rio Doce (MG) & (Gonçalves, 2007) & $34 \%$ \\
Araraquara (SP) & (Gameiro, 2005) & $45 \%$ \\
Vitória da Conquista (BA) & (Oliveira, 2005) & $51 \%$ \\
Rio Branco (AC) & (Rodrigues, 1997) & $58 \%$ \\
Belo Horizonte (MG) & (Faria, 2008) & $65 \%$ \\
Salvador (BA) & (Souza, 2011) & $69 \%$ \\
Rio de Janeiro & (Scherre \& Naro, 2010) & $73 \%(1980)$ \\
Rio de Janeiro & (Scherre \& Naro, 2010) & $83 \%(2000)$ \\
Interior paulista & BDI (2012) & $73 \%$ \\
Florianópolis (SC) & (Monguilhott \& Coelho, 2002) & $79 \%$ \\
S.Miguel dos Pretos (RS) & (Almeida, 2006a) & $81 \%$ \\
Pelotas (RS) & (Welchen, 2009, 2015) & $82 \%$ \\
Feira de Santana (culta) & (Araujo, 2014) & $93,9 \%$ \\
\hline
\end{tabular}

Tabela 5.10: Concordância sujeito/verbo em variedades do português brasileiro.

Diante dessas percentagens nota-se, de fato, a polarização entre as normas culta (urbana) e popular, sendo que a primeira apresenta maior ocorrência de marcação de plural no verbo enquanto que a norma popular apresenta baixa ocorrência de marcação de $\mathrm{CV}$, como as comunidades do interior da Bahia (Cinzento, Helvécia, Barra e Bananal) e Caiana dos Crioulos (PB), por exemplo, com 16\% e 17\% de ocorrência de concordância verbal, respectivamente, esses dois índices de comunidades quilombolas. 


\section{Capítulo 6}

\section{Concordância Verbal de 3PP nas Comunidades de Mamuna e Itamatatiua}

No capítulo anterior foram apresentados alguns dos trabalhos que analisam a variação na concordância verbal de terceira pessoa do plural. Foi possível observar, ao longo do referido capítulo, que as análises dessa variação, em sua quase totalidade, são feitas em uma perspectiva sociolinguística variacionista, algumas priorizando a análise quantitativa, outras a qualitativa.

O fato de as comunidades quilombolas pertencerem à área não urbana faz com que, em consonância com os demais estudos sobre o tema, seja esperada uma percentagem de não marcação de plural no verbo superior à de marcação de plural verbal. Contudo, a diferença entre a presença e a ausência de marca de plural no verbo não dá conta da análise dos dados das comunidades alcantarenses, uma vez que emerge uma terceira forma na marcação de plural de terceira pessoa.

Nesse sentido, a análise que será empreendida neste capítulo não se debruçará na questão que é amplamente discutida nos trabalhos sobre a variação da concordância verbal de terceira pessoa do plural, a saber, a presença ou a ausência de marca de plural no verbo. Logo, não faria sentido, neste momento da análise, explorar variáveis como saliência fônica e posição do sujeito condicionando a presença ou ausência de marcação de $\mathrm{CV}$, por exemplo, nos dados das comunidades quilombolas alcantarenses, 
uma vez que o foco, na presente análise, será, em primeiro lugar, explorar esta terceira forma de marcação de plural $^{1}$.

O que buscarei neste capítulo é descrever a marcação de terceira pessoa do plural que chamo de marcação intermediária - noção que ficará mais clara ao longo da descrição - e, complementarmente, evidenciar as consequências deste tipo de marcação, para, no capítulo seguinte, analisar essa marcação intermediária e sua possível relação com o contato linguístico.

\subsection{Origem da variação na concordância verbal}

Conforme explorado ao longo do capítulo 5, os estudos sobre esse tema consideram duas as variantes linguísticas da concordância verbal de terceira pessoa do plural: a presença (cf. (1), (3) e (5)) e a ausência de marca de plural no verbo (cf. (2), (4) e (6)), exemplificadas como segue ${ }^{2}$ :

(1) ELES FORAM para a cidade.

(2) ELES FOI para a cidade.

(3) ELAS DIZEM isso todo o tempo.

(4) ELES DIZ é muito isso.

(5) ELAS não CONSEGUEM chegar a tempo.

(6) ELAS não CONSEGUE chegar a tempo.

Nas sentenças (1) e (2) observa-se um alto nível de saliência fônica, isto é, a mudança para a forma plural envolve uma mudança saliente na base verbal com acréscimo de segmentos e mudanças diversas, ocorrendo até mesmo mudanças completas, como, por exemplo, o verbo ser (é/são) que possui um alto grau de saliência fônica.

Nos dados (3) e (4), a mudança da forma singular para a forma plural envolve acréscimo de segmentos, do mesmo tipo que ocorre no verbo quer/querem. O grau de saliência fônica não é tão alto quanto o dos dados anteriores, mas a passagem da forma singular para a plural ainda é bem perceptível em termos fonético-fonológicos. Já no último par de exemplos, (5)

\footnotetext{
${ }^{1} \mathrm{~A}$ análise empreendida na presente tese não desconsidera a importância dessas variáveis linguísticas, muito pelo contrário, no entanto, como, em princípio, as comunidades quilombolas alcantarenses apresentam um fenômeno distinto, buscarei, neste primeiro momento, descrever e apresentar as características desta marcação, procurando relacioná-la ao contato linguístico com as línguas africanas.

${ }^{2}$ Embora este não seja o foco das análises dos dados das comunidades de Alcântara, essas noções são importantes para o esclarecimento da noção de marcação intermediária da terceira pessoa do plural.
} 
e (6), a mudança da forma singular para a plural envolve a nasalização do segmento final, como em vive/vivem, gosta/gostam e a saliência fônica já não é tão perceptível.

Essas variações na CV, em especial a observada em (5) e (6), são explicadas, em algumas análises, pela perda da nasalização do último elemento. A discussão que se tem é se essa variação iniciou-se ou não a partir do enfraquecimento do segmento nasal.

A ideia de enfraquecimento fonético do segmento nasal que estaria conduzindo a uma erosão do morfema plural nas formas verbais tem início em Naro (1981). Essa erosão estaria levando a uma eliminação total da flexão verbal de pessoa e número, o que, por sua vez, traz consequências para a realização do sujeito pronominal.

$\begin{array}{ll}\text { Presente } & \text { Pret. Imperf. } \\ \text { eu estudo } & \text { eu estudava } \\ \text { você estuda } & \text { você estudava } \\ \text { ele estuda } & \text { ele estudava } \\ \text { a gente estuda } & \text { a gente estudava } \\ \text { vocês estuda(m) } & \text { vocês estudava(m) } \\ \text { eles estuda(m) } & \text { eles estudava(m) }\end{array}$

De acordo com Naro (1981), retomado em Naro \& Scherre (2007), o início do fenômeno da variação na concordância se deu no nível fonológico. Para os autores, tanto no PB quanto no PE houve desnasalização em toda a escala da saliência fônica - proposta por Naro (1981) - que se inicia no plano fonético-fonológico e se expande para o plano morfossintático.

A origem da variação na concordância verbal, para outros autores como Lucchesi (2006:99), por exemplo, estaria inicialmente ligada à inacusatividade verbal, ou seja, o enrijecimento da ordem SV deixaria os contextos VS para aqueles que veiculam a inacusatividade verbal e este contexto geraria uma variação na concordância verbal, pois os falantes entenderiam esse $\mathrm{S}$ posposto como um complemento verbal. A variação na $\mathrm{CV}$ teria sido intensificada posteriormente por um fortuito processo de enfraquecimento fonético ${ }^{3}$ da nasalidade do último segmento, na norma culta do português brasileiro. Aponta ainda para o fato de o português brasileiro, em especial o falado nas comunidades afro-rurais, estar em processo de aquisição da concordância verbal, uma vez que o autor percebe maior índice de ocorrência da marcação de $\mathrm{CV}$ na fala dos jovens.

\footnotetext{
${ }^{3}$ Os autores utilizam os termos fonético e fonológico indistintamente para explicar este processo de desnasalização do segmento final verbal.
} 
Já para Monguilhott (2009), uma mudança encadeia a outra, pois, ao que parece, a alteração no paradigma pronominal do português com a substituição de tu por você e do pronome nós pelo a gente ocasionou uma não obrigatoriedade de marcação da concordância no verbo, com consequente redução no paradigma flexional. Essa modificação acarretaria a necessidade da presença do sujeito expresso cada vez mais constante, levando o português do status de uma língua de sujeito nulo para uma língua de sujeito preenchido ${ }^{4}$.

Essa alteração irá promover a mudança na ordem do sujeito, ou seja, com a necessidade cada vez maior de preenchimento do sujeito, ocorre um enrijecimento na ordem SV, deixando, como já dito, a ordem VS para contextos de inacusatividade.

Em suma, não há consenso sobre se a variação na concordância verbal teve início devido a um enfraquecimento do segmento nasal final, ou se foi devida à inacusatividade verbal, ou ainda se foi à mudança no paradigma pronominal. $\mathrm{O}$ que se sabe é que esses três fatores têm influência na variação da $\mathrm{CV}$, independentemente de qual tenha iniciado o processo, e parece ser, conforme aponta Monguilhott, uma mudança encadeada à outra mudança, as quais trazem diversas consequências observadas hoje no $\mathrm{PB}$, como uma língua de sujeito preenchido, um paradigma pronominal reduzido, variação na concordância verbal, entre outras.

\subsection{Marcação padrão versus não padrão}

Os diferentes estudos sobre a CV consideram como marcação padrão de terceira pessoa do plural aquela que apresenta a marcação final $-m$, como andam/andavam, por exemplo, e muitos desses trabalhos contrapõem essa marcação à ausência de marca no verbo, como em eles anda / eles andava.

Na norma popular é possível encontrar marcações como eles andavo / eles andaro, que seria uma marcação intermediária entre a total ausência de marca de plural no verbo e a presença do morfema de indicador de plural $-m$.

Tanto Raimundo (1933: 69) quanto Mendonça (1933) atribuíram essa ocorrência à influência africana que, de acordo com eles, teria ocasionado a mudança tanto na nasal final quanto no ditongo final - ão. O primeiro apresenta exemplos como tocaram - tocaru, órfão - órfu, vezaram-se - se arrivezáro-se (o mesmo que enraivecer-se). Já Mendonça, ao apontar para

\footnotetext{
${ }^{4} \mathrm{~A}$ ideia de que o PB estaria se tornando uma língua de sujeito preenchido já foi amplamente explorada por diversos autores, como, por exemplo, Duarte (1993, 2000, 2003); Cyrino \& Duarte (2000); Buthers \& Duarte (2012), entre outros.
} 
os vestígios deixados pelos africanos na morfologia da língua portuguesa, observa (Mendonça, 1933: 86):

“Temos outrossim ouvido, no Distrito Federal, a terminação am da $3^{a}$ pessoa do perfeito do indicativo soar o átono na pronúncia dos pretos e gente de sua classe: amaram ...amaro, fizeram ...fizero, disseram ... dissero."

Castro (2001) igualmente atribui a perda da nasalização final à influência das línguas africanas, chamando atenção ao fato de este fenômeno também ocorrer em terras africanas, onde os falantes desconheceriam as vogais nasais, pronunciando, por exemplo, palavras do tipo benção, sótão, camisão, homem, coragem como bença, sótu, camisu, homi e coragi, respectivamente. Contudo, essa afirmação deve ser ponderada, pois há, sim, línguas africanas, inclusive do tronco nigero-congolês, que possuem vogais nasais como, por exemplo, a língua ijó, a jukun e a eve, que possui sete vogais nasais. Talvez essa pudesse ser uma estratégia influenciada pelas línguas africanas que possuem tendência em evitar ditongos (Heine \& Leyew, 2008) e não pelo fato de desconhecerem vogais nasais.

Fora das comunidades quilombolas e populares, esse fenômeno é observado no Nordeste por Marroquim (1934). Em Alagoas e Pernambuco há a ocorrência de exemplos como fizeram - fizero, amaram - amaro, mataram - mataro, foram - foro e a redução de ditongos ão finais átonos como órfão órfo, Estevão - Estevo, órgão - órgu. A perda da nasalização é evidenciada também em finais de palavras como homem - homi, ontem - onti, coragem coragi.

Embora atestada, poucos são os trabalhos que, ao falar da variação na concordância verbal em termos morfossintáticos, tratam dessa marcação não padrão de maneira separada das demais. É possível observar, no entanto, a análise desse tipo de marcação de maneira mais detida em estudos fonológicos, apresentados no próximo capítulo.

Lucchesi et al. (2009), ao analisarem comunidades quilombolas da Bahia, verificam essa marcação intermediária terminada em $\{-0\}$ juntamente com marcação padrão de plural, conforme dado em (7), utilizado para exemplificar o papel do traço semântico [+humano] do sujeito no favorecimento da marcação de plural.

$$
\text { ALGUMAS PESSOA DERO. }
$$

(Lucchesi et al., 2009:354)

Ao analisar a comunidade quilombola de São Miguel dos Pretos, no Rio Grande do Sul, Almeida (2006a) faz a distinção entre a marcação padrão 
e não padrão de plural no verbo. Considera a marcação intermediária do tipo andaro, no entanto, a analisa juntamente com a ausência de marca de plural no verbo, conforme sequência de dados de (11) a (14) a seguir:

Ocorrência padrão

(8) ... AS PESSOAS NÃO FAZEM quase os cursos que tem aqui.

(9) VOCÊS VÃO DAR andamento em tudo.

(10) ... e aí NÓS DIALOGAMOS com ele ali.

(Almeida, 2006a: 56)

Ocorrência não padrão

(11) ESSAS TERRAS TÁ fechada.

(12) Não sei se VOCÊS CONFIRMARU...

(13) NÓS NÃO TEMU canteiro para plantar isso...

(14) Não, NÓS MORAVA noutro lado.

(Almeida, 2006a: 56)

Analisando três comunidades no interior da Bahia, entre elas a comunidade quilombola de Cinzento, Silva (2005) também não faz a distinção de marcação padrão versus marcação intermediária, porém, considera, assim como Lucchesi et al. (2009), essa marcação que estamos chamando de intermediária juntamente com marcação padrão de plural, como é possível observar em (15), utilizado para exemplificar núcleo do SN adjacente ao verbo com marca de plural, e (16), utilizado para demonstrar o efeito gatilho, ou seja, em que medida a fala do documentador influencia a fala do informante, com marcação de plural.

(15) OS MENINOS TIRARO.

(16) Muitos DELES VIAJARO.

(Silva, 2005: 167)

Este tipo de marcação também é atestada na fala de Copacabana, no Rio de Janeiro (Vieira et al., 2015), porém, restrita apenas ao pretérito imperfeito (17) a (19), a contextos diante de consoante [- nasal ], como [f] e [p] em (20), e diante de pausa (21):

(17) eles TOCAVU guitarra violão

(18) os meus primo todos eles TOCAVU né? 

aí os vizinho né lá ... tudo ...PARTICIPAVU né?

(Vieira et al., 2015: 138)

(20) tem muitos garoto amigo meu aqui que FIZERU faculdade né ...é ... estudaram ... trabalham TUVERU profissão nem todos né ... você sabe né ... toda comunidade tem boas.

(21) esses esgoto é ainda aqueles esgoto que os portugueses FIZERU ...

(Vieira et al., 2015: 140)

O que é possível notar é que, nos trabalhos sobre a variação na marcação de plural verbal de terceira pessoa no PB, um ou outro apresenta dados com esse tipo de marcação e, dentre aqueles que apresentam, poucos são os que distinguem claramente como irão tratá-la, se como uma marca de plural juntamente com a marcação de plural padrão, como Lucchesi et al. (2009), Silva (2005) e Araujo (2014), por exemplo, ou como uma marcação não padrão analisada juntamente com a ausência de marca de plural, como a exemplo de Almeida (2006a) e Welchen (2015). Isso se deve, talvez, ao fato de esse tipo de marcação ocorrer de forma marginal, ou em contextos esperados, os de terceira pessoa no pretérito.

No português europeu, mais precisamente na variedade urbana insular de Funchal, na Ilha de Madeira, ocorrem duas variantes não padrão de marcação de plural: a primeira representada por-EM e a segunda representada por -U, que pode ocorrer com a vogal nasal [ũ] ou oral [u], dependendo do traço nasal do contexto fonético seguinte (Vieira \& Bazenga, 2015: 39). Esse padrão, contudo, representa apenas 9\% dos dados, ou seja, em um total de 866 ocorrências, essa marcação não padrão se dá 83 vezes, porém, representa quase o dobro de ocorrências de terceira pessoa plural sem qualquer marca no verbo $(5,3 \%)$.

Esta variedade se distingue de outras variedades do PE no tocante aos traços fonéticos como, por exemplo, as ditongações das vogais /i / e / u / tônico (navio > naveie; lua > laua), de /o/ em palavras como boa (baua); a palatalização de /1/ antes de /i/ ou /j/ (aquilo>aquilho), entre outros (Bazenga, 2015).

As realizações não padrão de Funchal estão restritas ao pretérito imperfeito do indicativo e esse tipo de marcação diferenciaria esta variedade insular de outras variedades do português europeu. Apresento a seguir dados com o segundo tipo de marcação não padrão, que se relacionam diretamente com os dados das comunidades maranhenses explorados na tese:

(22) eles VINHO brincar. 
Essa marcação, com as formas [o] e [u], "resultaria de um processo de desnasalização do ditongo nasal em [w] e posterior redução do ditongo nas vogais labiais. A forma [ũ] corresponderia apenas a um processo de redução do ditongo mas sem a ocorrência da desnasalização" (Vieira \& Bazenga, 2015: 41).

Bazenga (2015: 87) e Vieira et al. (2015: 124) apresentam a variante em -U como "histórica" ou "conservadora", associada às vogais existentes no

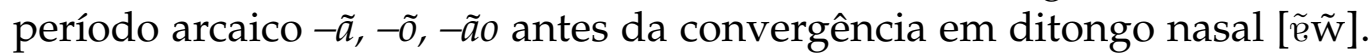
No entanto, a história de formação da Ilha da Madeira também poderia trazer uma explicação para a ocorrência dessas marcações não padrão que diferenciam esta variedade das demais faladas no continente.

A Ilha da Madeira, descoberta em 1416, nunca ficou totalmente isolada, pois, além do cultivo da cana-de-açúcar e posteriormente da vinha, era lugar de paragem obrigatória para os que passavam pelo oceano Atlântico, especialmente Funchal, cidade portuária considerada um ponto de ancoragem estratégico nas viagens atlânticas, situação que perdurou até o século XIX.

Diante disso, a sociedade madeirense pode ser considerada como o resultado de fluxos migratórios desde a sua descoberta, com a presença de comerciantes, sobretudo europeus (florentinos, genoveses, flamengos, espanhóis, franceses, bretões, galegos, cristãos-novos, entre outros), e de escravizados vindos da África. O contato gerado por sucessivas ondas de migração - imigração, emigração e retorno à ilha - moldou o perfil da população da Ilha da Madeira (Bazenga, 2015; Mota, 2015).

Informação importante também é o pequeno número de europeus, chamados "homens bons", que formaram a elite da Ilha da Madeira, além da falta de atenção do governo central, o que ocasionou um certo isolamento e independência política e financeira em relação a Portugal continental. Este certo isolamento do continente, em termos de relações, pode também ter acentuado as mudanças ocorridas na variedade falada nesta ilha.

Esse contato interferiu não apenas no "perfil genético" da população madeirense, mas também pode ter interferido nos aspectos linguísticos que diferenciam esta variedade das variedades portuguesas continentais, logo, tais marcações não padrão atestadas na variedade de Funchal poderiam ser, ao invés de uma marcação "conservadora", conforme apontado pelas autoras Bazenga (2015) e Vieira et al. (2015), resultado do constante contato 
com diferentes povos ocorrido ao longo da história de formação desta sociedade insular ${ }^{5}$.

Vieira (2015a) aponta para o fato de o debate sobre a influência do componente fonético-fonológico na marcação de terceira pessoa do plural residir basicamente na variável saliência fônica, e ainda:

Não obstante o controle sistemático do referido grupo de fatores nos estudos sociolinguísticos, deve-se observar que, até onde se sabe, não se dispõe, em estudos variacionistas [...] de levantamento de dados sistemático quanto às realizações fonéticas das terminações verbais. Assim, não se apresentam evidências suficientes para postular padrões fonéticos de marcação de pluralidade concretizados nas variedades brasileiras, europeias e sobretudo africanas do Português (Vieira, 2015a: 25).

Os estudos apresentados reforçam a importância dos aspectos morfofonológicos dentro dos estudos sobre a concordância verbal, já apontada por diferentes autores (Mota, 2013; Vieira, 2015a, entre outros), que fortalecem o fato de que a existência de concordância e a presença de marcas plurais constituem duas questões separadas. Logo, para entender a marcação da $\mathrm{CV}$, bem como a variação desta marcação, é preciso não apenas olhar para os aspectos sintáticos do fenômeno, mas também levar em consideração os aspectos fonéticos e morfofonológicos.

\subsection{Introduzindo os dados}

Para efeitos didáticos e entendimento dos dados que serão apresentados, a marcação considerada como intermediária é composta por formas do tipo andaro, falaro, comero, entre outras. Esta marcação é percebida aqui, em termos morfológicos, entre a total ausência de marca de plural no verbo e a marcação de plural verbal padrão. As ocorrências de terceira pessoa do plural são consideradas nesta tese conforme segue:

- Marcação padrão de plural

Eles/elas andavam

Eles/elas comiam

Eles/elas falam

\footnotetext{
${ }^{5}$ Esta é apenas uma sugestão de análise de como o fenômeno também poderia ser explicado pelo contato entre as diferentes línguas que conviveram na Ilha da Madeira, em consonância com a análise realizada por Mota (2015).
} 
- Marcação intermediária

Eles/elas andavo

Eles/elas comio

Eles/Elas falo

- Marcação não padrão - sem marca verbal

Eles/elas andava

Eles/elas comia

Eles/elas fala

Nas comunidades quilombolas de Alcântara evidencia-se a variação na concordância verbal, com a ocorrência dos três tipos exemplificados anteriormente, conforme tabelas a seguir:

\section{- Itamatatiua}

\begin{tabular}{|l|c|c|}
\hline Tipo de concordância & Quantidade & Percentagem \\
\hline \hline Padrão & 8 & $3,5 \%$ \\
Intermediária & 170 & $80 \%$ \\
Sem marcação & 35 & $16,5 \%$ \\
\hline \hline TOTAL & 214 & $100 \%$ \\
\hline
\end{tabular}

Tabela 6.1: Variação na marcação de CV na comunidade de Itamatatiua

- Mamuna

\begin{tabular}{|l|c|c|}
\hline Tipo de concordância & Quantidade & Percentagem \\
\hline \hline Padrão & 98 & $28 \%$ \\
Intermediária & 212 & $60 \%$ \\
Sem marcação & 45 & $12 \%$ \\
\hline \hline TOTAL & 358 & $100 \%$ \\
\hline
\end{tabular}

Tabela 6.2: Variação na marcação de CV na comunidade de Mamuna

Em uma comparação preliminar, observa-se número maior de ocorrência do plural padrão na comunidade de Mamuna, consequentemente a 
intermediária é menor nessa comunidade. A percentagem de não ocorrência de marcação de plural, no entanto, é até próxima nas duas comunidades, $16,5 \%$ em Itamatatiua e 12\% em Mamuna.

Ainda em termos preliminares de comparação, vemos que as comunidades de Alcântara diferem de outras comunidades quilombolas estudadas, em especial na Bahia (ver Lucchesi et al., 2009; Silva, 2005 e Lima, 2014), onde o plural padrão não ultrapassa os 18\%, mesmo para os que o analisam junto com a intermediária.

Caso eu fosse considerar a marcação padrão juntamente com a intermediária, a exemplo de outros autores (ver Lucchesi et al., 2009; Silva, 2005, Lima, 2014 e Araujo, 2014), a frequência de ocorrência da CV nas comunidades de Alcântara ficaria:

- Itamatatiua

\begin{tabular}{|l|c|c|}
\hline Tipo de concordância & Quantidade & Percentagem \\
\hline \hline Padrão e Intermediária & 178 & $83,5 \%$ \\
Sem marcação & 35 & $16,5 \%$ \\
\hline \hline TOTAL & 214 & $100 \%$ \\
\hline
\end{tabular}

Tabela 6.3: Marcação intermediária somada à marcação padrão - Itamatatiua

- Mamuna

\begin{tabular}{|l|c|c|}
\hline Tipo de concordância & Quantidade & Percentagem \\
\hline \hline Padrão e Intermediária & 310 & $88 \%$ \\
Sem marcação & 45 & $12 \%$ \\
\hline \hline TOTAL & 358 & $100 \%$ \\
\hline
\end{tabular}

Tabela 6.4: Marcação intermediária somada à marcação padrão - Mamuna

Se a análise fosse estabelecida nesses termos - marcação padrão junto com intermediária - , os dados aproximariam as comunidades quilombolas de Alcântara dos falares urbanos cultos, ou ainda à comunidade de São Miguel dos Pretos, no Rio Grande do Sul (Almeida, 2006a), contudo, não é possível fazer essa afirmação.

A decisão de analisar a marcação intermediária separada da padrão se dá pelo fato de que, embora a primeira apresente uma marca de plural no verbo, não se pode dizer que é do mesmo tipo da que ocorre em plurais 
padrão, logo, não pode ser comparada à fala urbana culta. Isso mostra que uma análise puramente quantitativa poderia levar, nesse caso, a um resultado enviesado dos dados.

Outro fator que levou à separação deste tipo de ocorrência, além do fato de dar-se em maior número, são os contextos nos quais essa marcação intermediária acontece, pois difere dos estudos que apresentaram esse final

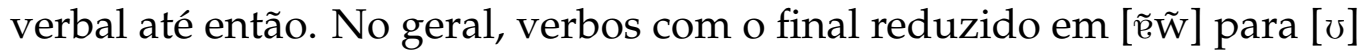
ocorrem no tempo pretérito, especialmente no perfeito, porém, os dados das comunidades Itamatatiua e Mamuna exibem esse tipo de redução verbal também no tempo presente, em verbos irregulares e em verbos de $2^{a}$ conjugação.

Diante disso, a divisão dos dados em relação à variação na ocorrência de CV das comunidades de Itamatatiua e Alcântara será a apresentada nas tabelas 6.1 e 6.2 .

\subsection{Marcação intermediária}

Conforme dito anteriormente, na norma popular é possível encontrar formas do tipo eles andavo / eles andaro, que considero como uma marcação intermediária entre a total ausência de marca de plural no verbo e a presença do morfema indicador de plural, ortograficamente transcrito como $-m$.

Novamente, tanto Raimundo (1933: 69) quanto Mendonça (1933) atribuíram essa redução final à influência africana, assim como Castro (2001), que sustenta o fato de as línguas africanas "desconhecerem as vogais nasais".

Tanto a comunidade de Itamatatiua quanto a de Mamuna exibem a marcação que estou chamando de intermediária em maior número; os exemplos são apresentados a seguir em (25) e (26):

(26) é engraçado ... eu sei que ... moléstia ELES TROUXERO muito ... muita ... benefício bem pouco que era pra ter uma escola muito boa ... feita pelo Governo Federal né não? — MGS/MMN

Em um mesmo contexto podem acontecer dois tipos de plural, como em (27), por exemplo, em que há o verbo com plural não padrão em as criança ganhava e o verbo com marcação intermediária em eles vinho. No 
dado (28) observa-se o plural padrão em eles diziam e o plural intermediário em eles aposentavo.

(27) nesse sítio dava muita gente ... muita ... chega zuava só de gente ... boi ... porquinho porquinho porquinho ... festa de Santa Teresa ... ah agó/ óia aqui no meio do sítio a gente via era só bancada ... que AS CRIANÇA GANHAVA dinheiro que ELES VI$\mathrm{NHO}$... fazer aquelas ... mesinha assim ... pa botar as coisa em cima ... roupa tudo ... e agora hoje a senhora não vê nenhuma ... bancadinha no meio do sítio com as coisa - MJ/ITM.

(28) ELES DIZIAM que o cara ia no caminho ... levava uma topada ... quebrava a cabeça dele ia lá e ELES APOSENTAVO —JB/ITM

Importante frisar que não se trata apenas do apagamento do segmento nasal ou do glide no final do verbo, mas sim de uma reanálise dessa morfologia final de plural [ $\tilde{\mathrm{v}} \tilde{\mathrm{w}}]$, em que $\operatorname{mand}[\tilde{\mathrm{e}} \tilde{\mathrm{w}}]$ vira $\operatorname{mand}[v]$, acredit $[\tilde{\mathrm{e}} \tilde{\mathrm{w}}]$

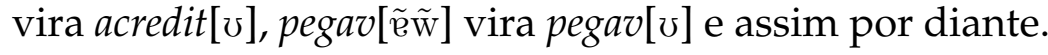

\subsubsection{Marcação intermediária no passado}

Dos 382 dados com plural intermediário, considerando tanto os dados de Mamuna quanto os de Itamatatiua, 184 encontram-se com o verbo flexionado no passado, número que corresponde a $48 \%$ do total. A hipótese defendida é que o final reduzido foi reanalisado como um morfema marcador de plural na terceira pessoa, sendo ampliado para contextos em que este tipo de redução não ocorre em outras comunidades, como verbos no presente, por exemplo.

Nas comunidades alcantarenses a marcação intermediária acontece, em maior número, em verbos flexionados no pretérito perfeito (29), contudo, também é atestado em verbos flexionados no pretérito imperfeito (30):

OS MAIS VELHO que talvez que plantasse ... já MORRERO tudo - RNJ/ITM aí AS PESSOA ENSINAVO lá também — ENJ/ITM

A ocorrência neste tempo verbal, conforme já observado, não difere da observada nas comunidades analisadas em outros estudos, como Cinzento e Helvécia, na Bahia (Lucchesi et al., 2009; Silva, 2005) e Caiana dos Crioulos (PB) (Lima, 2014), ou ainda de falares nordestinos (Marroquim, 1934).

Para a descrição do plural intermediário, os tipos de sujeito foram divididos, com base em Monte (2012), em: pronomes pessoais 'eles/elas' com 
referência determinada; pronomes pessoais 'eles / elas' com referência vaga ou indeterminada; nomes substantivos no singular com um ou mais determinantes no plural; nome substantivo no plural; outros pronomes; numeral no plural; dois ou mais núcleos; sujeito nulo e sujeito com pronome relativo 'que'.

Vale reforçar que as variáveis linguísticas não são analisadas nos mesmos termos que os estudos apresentados no capítulo 5.

\begin{tabular}{|l|c|c|}
\hline Variável & Quantidade & Percentagem \\
\hline \hline Eles(as) de referência definida & 113 & $61,4 \%$ \\
Eles(as) ref. vaga /indeterminada & 17 & $9,2 \%$ \\
Marcação singleton & 23 & $12,5 \%$ \\
Substantivo plural & 11 & $6 \%$ \\
Outros pronomes & 2 & $1 \%$ \\
Número plural & 1 & 0,6 \\
Dois ou mais núcleos & 3 & $1,6 \%$ \\
Sujeito nulo & 12 & $6,5 \%$ \\
Pronome relativo 'que' & 1 & $0,6 \%$ \\
\hline \hline TOTAL & 183 & $100 \%$ \\
\hline
\end{tabular}

Tabela 6.5: Marcação intermediária no pretérito - Mamuna e Itamatatiua

Importante notar que, independentemente se de referência determinada ou vaga, os sujeitos com pronomes pessoais de terceira pessoa do plural correspondem a 70,6\% do total dos dados com verbos flexionados no pretérito, tanto perfeito quanto imperfeito.

- Pronomes pessoais 'eles / elas' com referência determinada

(31) porque aí ELES FUGIRO mas num TINHO ... nada num TINHO ... caldeirão num TINHO ... colher não tinha prato num tinha pote né pa botar as coisa - NJ/ITM

(32) ano passado a gente foi pr'uma feira em São Bento que ELES ORGANIZARO lá ... os pessoal ... de lá de Alcântara — NJ/ITM

(33) olha num instante ELES FIZERO pra lá ... TIRARO tudo daí CARREGARO pra lá -MGS/MMN

(34) e os malofícios que ELES PROVOCARO com tudo isso ...com isso ELES TIRARO parte do palmeiral que a comunidade aqui se usufruia - MGS/MMN 
(35) e ES MEDIRO quintal MEDIRO quantas plantações você tinha (...) mas não CONSEGUIRO tirar não CONSEGUIRO (...) não CONSEGUIRO porque nós ti / fomos informados ... tivemos bastante apoio ... né ...entidades - NDS/MMN

(36) eu sei que ELES FIZERO naquela vez né uma barricada pra pa impre/ impedir que eles entrasse - LSM/MMN

- Pronome pessoal 'eles' com referência vaga/indeterminada

(37) eles diziam que o cara ia no caminho ... levava uma topada quebrava a cabeça dele ia lá e ELES APOSENTAVO — JB/ITM

(38) aí surgiu essa aposentadoria ELES BOTARO ... surgiu a Bolsa Escola ELES BOTARO - RJ/ITM

(39) este dia eu vi o ... ELES TAVO falando ... pela televisão que ... a pessoa que quisesse fazer faculdade ... eles já já tinha uma lei $\mathrm{RJ} / \mathrm{ITM}$

- Marcação singleton 6

(40) OS MAIS VELHO que talvez que plantasse ... já MORRERO tudo $-\mathrm{RNJ} / \mathrm{ITM}$

(41) aí AS PESSOA ENSINAVO lá também — ENJ/ITM

(42) agora que os pe/ OS (HOMEM) se AJUNTARO e ARRUMARO um pouco - DJ/ITM

(43) num achei assim tirar AS PESSOA que MORAVO ali ni ... Peru ... pra perto ainda não TIRARO ... Baracatatiua - IPM/MMN

(44) AS PESSOA ACEITAVO e nessa época também era a ditadura militar ... chegava e tirava como fez da banda do (...) a Peru Marudá ... Titica — MJLP/MMN

- Nome substantivo no plural

o AS CAIXEIRAS mais ... antiga já MORRERO — ENJ/ITM

(46) têm PESSOAS aí NASCERO e se CRIARO nesta comunidade MGS/MMN

(47) ALGUMAS PESSOAS ... que se DESTACARO ... algumas pessoa - MGS/MMN

${ }^{6}$ Marcação que exibe apenas uma marca explícita, de pessoa e número, no pronome sujeito. 
(48) aí AS PESSOAS COMEÇARO se desenvolver - MJLP/MMN

(49) ESSAS PESSOAS não CONVIVERO com você elas num têm vínculo nenhum com você - MJLP/MMN

(50) TODOS AS MÃES que já VIRO que já OLHARO as luta - MJLP/MMN

- Outros pronomes

(51) ano passado ficou ... foi UNS PASSARO quase quinze dias aí $\mathrm{ENJ} / \mathrm{ITM}$

(52) OS OUTRO FORO embora pa São Luís ... teve UNS que FORO embora pa São Luís - NJ/ITM

- Numeral no plural

(53) TODOS OS DOI MORRERO aí ... graças a Deus foi uma bença $\mathrm{CD} / \mathrm{MMN}$

- Dois ou mais núcleos

(54) A MINHA MÃE ... verdadeira mais MEU PAI ... MORRERO — $\mathrm{MAJ} / \mathrm{ITM}$

(55) aí MEU FILHO mais velho com OUTRO RAPAZ ... TIRARO o maderame tudim - MJLP/MMN

- Sujeito nulo

(56) Era festa de São Sebastião nunca mais FIZERO — MJ/ITM

(57) achei muito bom mesmo ... legal muito RECEBERO a gente muito ... bem - MAJ/ITM

(58) perguntando como fez a ... como foi a cerâmica ... quem começou fazer ... como COMEÇARO ... né - NJ/ITM

(59) maior burocracia ainda DERO uma área ... que não era uma a/ não é uma área totalmente apropriada - MGS/MMN

(60) certo os que tão lá inda não ...já MORRERO muito mas não de fome né - MFF/MMN

- Com pronome relativo 'que' 
(61) é porque o ... OS QUE GOSTAVO do serviço ... é como eu tô dizendo ... já MORRERO tudo já FICARO velho os que ainda têm não pode mais fazer - RNJ/ITM

Já para os verbos com plural padrão no passado, a proporção fica próxima à encontrada nos verbos de marcação intermediária.

\begin{tabular}{|l|c|c|}
\hline Variável & Quantidade & Percentagem \\
\hline \hline Eles(as) de referência definida & 51 & $65,5 \%$ \\
Eles(as) ref. vaga /indeterminada & 2 & $2,5 \%$ \\
Marcação singleton & 3 & $3,8 \%$ \\
Substantivo plural & 13 & $16,7 \%$ \\
Outros pronomes & 2 & $2,5 \%$ \\
Número plural & 1 & $1,2 \%$ \\
Dois ou mais núcleos & - & - \\
Sujeito nulo & 6 & $7,8 \%$ \\
Pronome relativo 'que' & - & - \\
\hline \hline TOTAL & 78 & $100 \%$ \\
\hline
\end{tabular}

Tabela 6.6: Marcação padrão de plural no verbo no pretérito - Mamuna e Itamatatiua

Para os verbos no passado sem qualquer marca morfológica no verbo, a proporção diminui um pouco.

\begin{tabular}{|l|c|c|}
\hline Variável & Quantidade & Percentagem \\
\hline \hline Eles(as) de referência definida & 11 & $39 \%$ \\
Eles(as) ref. vaga /indeterminada & - & - \\
Marcação singleton & 10 & $36 \%$ \\
Substantivo plural & 4 & $14,3 \%$ \\
Outros pronomes & 2 & $7,2 \%$ \\
Número plural & - & - \\
Dois ou mais núcleos & - & - \\
Sujeito nulo & - & - \\
Pronome relativo 'que' & - & - \\
\hline \hline TOTAL & 27 & $100 \%$ \\
\hline
\end{tabular}

Tabela 6.7: Verbos sem marcação de plural no verbo no pretérito - Mamuna e Itamatatiua

Nas comunidades alcantarenses, as ocorrências padrão e não padrão também diferem das de outras comunidades quilombolas ou de falares de 
zonas não urbanas, pois a primeira ainda é superior à não padrão, com $27,6 \%$ e $9,5 \%$, respectivamente. A intermediária ainda representa a maior parte dos dados, com $62,8 \%$ de ocorrência com verbos no pretérito, tanto perfeito quanto imperfeito. No entanto, a proporção de ocorrência quanto ao tipo de sujeito permanece a mesma nos três tipos de plural de terceira pessoa.

\subsubsection{Marcação intermediária no presente}

Diferentemente de outras comunidades não urbanas, ou mesmo de algumas comunidades urbanas em que esta redução é possível, nas comu-

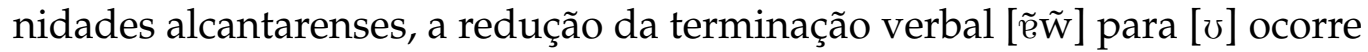
em verbos no tempo presente (cf. sequência de (62) a (65)):

(62) [Falando sobre os mais jovens e sobre a falta de trabalho na comunidade.] ELES num PENSO ... num sabe pensare ... se PENSO mas num quere né? - CJ/ITM

(63) é como eu digo ... esse dinheiro num é deles ... esse dinheiro é do governo ... tá vendo? é do governo ... então aí ELES FICO com a maior banca ... botando a maior banca com coisa que o dinheiro é deles - RJ/ITM

(64) com esse estudo que o Governo Federal de ...fazer ... um ... só uma centranização ... só um um colégio ... o que que acontece ... as criança fica prejudicada [...] vai ter semana que passa a semana todinha sem vim buscar as criança ... porque não tem ...o ... o ônibus tá com pneu furado ELES não AVISO ... entendeu? MJLP/MMN

(65) [Falando sobre os turistas que vão à Mamuna conhecer a praia] até tem vez ... que passa ... tem vez que passa quando vem assim da Alemanha ... quando assim ... às vez ELES PASSO dois três cinco dias ... PASSO ... mas a maioria só visita mesmo — NDS/MMN

Em relação ao tipo de sujeito, foram considerados os mesmos apresentados em 6.4.1. Os resultados são os que seguem: 


\begin{tabular}{|l|c|c|}
\hline Variável & Quantidade & Percentagem \\
\hline \hline Eles(as) de referência definida & 55 & $56,7 \%$ \\
Eles(as) ref. vaga /indeterminada & 21 & $21,6 \%$ \\
Marcação singleton & 9 & $9,2 \%$ \\
Substantivo plural & 7 & $7,2 \%$ \\
Outros pronomes & 5 & $5,3 \%$ \\
Número plural & - & - \\
Dois ou mais núcleos & - & - \\
Sujeito nulo & - & - \\
Pronome relativo 'que' & - & - \\
\hline \hline TOTAL & 97 & $100 \%$ \\
\hline
\end{tabular}

Tabela 6.8: Marcação intermediária de plural no verbo no tempo presente Mamuna e Itamatatiua

Se somarmos, dentro da ocorrência de marcação intermediária de plural, os pronomes eles(as) de referência definida com os de referência vaga ou indeterminada, o resultado é de $76 \%$ dos dados, uma proporção muito próxima à encontrada com os verbos no pretérito (70\%). Esse tipo de pronome representa a maioria dos dados de terceira pessoa no geral, logo, espera-se que a proporção para ele seja realmente superior.

- Pronomes pessoais 'eles / elas' com referência determinada

(66) eu não sei nem se ELAS ainda PAGO Associação ... será que PAGO? - MJ/ITM

(67) mas a maioria da juventude ...ELES ACHO ... que o pai tá no direito ... de subsistir ele o tempo todo - JB/ITM

(68) bastante jovens ... são tudo envolvido ... ELES CANTO ELES REPRESENTO ... aí toda boca da noite eles tão ensaiando - MFF / MMN

(69) aliás todos ELES GOSTO de estudar meus filho (... ) não perde aula só se eles tivere doente - LSM/MMN

- Pronome pessoal 'eles' com referência vaga/indeterminada

(70) geralmente algum problema que ELES ARRUMO e a pessoa acaba ficando lá - MJLP/MMN

- Nome substantivo no singular com um ou mais determinantes no plural 
(71) os OS RAPAZINHO é assim ... quer também botar logo mulher ... e nunca que se PREPARO pa mais tarde - RJ/ITM

(72) é conseguido AS PESSOA que TRABALHO na roça - ACJ/ITM

(73) aí AQUELES COLEGA FORMO jogo no campo aí vão levar a cesta básica - LSM/MMN

- Nome substantivo no plural

(74) agora OS NOVOS que num GOSTO de nada ... num quere participar de nada - MGS/MMN

(75) hoje AS PESSOAS ... TRABALHO com mais confiança — MJLP/MMN

- Outros pronomes

(76) UNS se AGRADO OUTROS num se AGRADO - ACJ/ITM

(77) OUTROS ENTRO porque GOSTO e ACHO bonito ... mas tem MUITOS que ENTRO por necessidade - MJLP/MMN

Para o plural padrão, a proporção já é um pouco diferente: a percentagem com pronome eles/elas diminui para $29,7 \%$ e os nomes substantivos no plural representam o maior número de dados com plural padrão no tempo presente, 10 dados (37\% do total).

\begin{tabular}{|l|c|c|}
\hline Variável & Quantidade & Percentagem \\
\hline \hline Eles(as) de referência definida & 6 & $25 \%$ \\
Eles(as) ref. vaga /indeterminada & 2 & $8,3 \%$ \\
Marcação singleton & 3 & $12,5 \%$ \\
Substantivo plural & 10 & $41,7 \%$ \\
Outros pronomes & 2 & $8,3 \%$ \\
Número plural & - & - \\
Dois ou mais núcleos & - & - \\
Sujeito nulo & 1 & $4,2 \%$ \\
Pronome relativo 'que' & - & - \\
\hline \hline TOTAL & 24 & $100 \%$ \\
\hline
\end{tabular}

Tabela 6.9: Marcação padrão de plural no verbo no tempo presente - Mamuna e Itamatatiua

Já em relação aos dados de plural não padrão em verbos no tempo presente, a proporção em relação ao tipo de sujeito se mantém parecida à 
proporção da marcação intermediária, com o pronome eles/elas representando $68 \%$ do total.

\begin{tabular}{|l|c|c|}
\hline Variável & Quantidade & Percentagem \\
\hline \hline Eles(as) de referência definida & 19 & $68 \%$ \\
Eles(as) ref. vaga/indeterminada & - & - \\
Sub. sing. determinante plural & 2 & $7 \%$ \\
Substantivo plural & 4 & $14,5 \%$ \\
Outros pronomes & 1 & $3,5 \%$ \\
Número plural & 1 & $3,5 \%$ \\
Dois ou mais núcleos & - & - \\
Sujeito nulo & - & - \\
Pronome relativo 'que' & - & - \\
\hline \hline TOTAL & 27 & $100 \%$ \\
\hline
\end{tabular}

Tabela 6.10: Sem marca de plural em verbos no tempo presente - Mamuna e Itamatatiua

Para os verbos no presente, não há diferença entre o plural padrão e o não padrão, com $17,5 \%$ e $18 \%$, respectivamente. O intermediário se mantém como o de maior ocorrência, com $64,5 \%$ dos dados. Logo, independentemente de o verbo encontrar-se no pretérito ou no presente, a marcação intermediária ainda corresponde ao maior número de dados, com percentagens bem próximas, inclusive. É possível afirmar que ela é predominante nas comunidades alcantarenses a despeito do tipo de sujeito e do tempo verbal.

Uma consequência importante quando o verbo está no presente é que essa marca começa a confundir-se com a flexão de primeira pessoa do singular, podendo estar presente inclusive em uma mesma sentença (cf. (78)):

(78) eu conheço São Bento ... Pinheiro ... pa Alcântara eu vou todo mês ... umum ... Bequimão ... por aqui perto tudo eu já fui ... EU só não VIAJO com elas assim ... porque ELAS VIAJO pra fora ...é porque num tem quem fique em casa ...num é? - CJ/ITM

Em (78), a única distinção entre as duas ocorrências é o pronome pessoal, pois a forma verbal é homônima, logo, a presença do pronome pessoal se faz cada vez mais importante para que não haja confusão nem prejuízo para a interpretação ${ }^{7}$.

\footnotetext{
${ }^{7}$ No dado em questão, a transcrição e análise fonética se faz pertinente para, por exemplo, verificar se há nasalização na forma de terceira pessoa, com o intuito de assegurar
} 
Este também seria então outro fenômeno, ao lado da redução do paradigma verbal, que reforça a necessidade da presença do pronome sujeito na sentença, fato que, entre outros, demonstra que o português brasileiro tem se tornado cada vez mais uma língua de sujeito preenchido ${ }^{8}$. Enquanto na redução do paradigma verbal a única forma verbal distinta é a de primeira pessoa e a presença do pronome sujeito é necessária a fim de se distinguir a forma verbal entre os demais pronomes (você/vocês, ele/eles e a gente) ver seção 6.1, capítulo 6-, nas comunidades alcantarenses, a presença do pronome se faz necessária, quando na terceira pessoa do plural no tempo presente, para distinguir a primeira da terceira pessoa.

Ao que parece, a marcação intermediária não é apenas numericamente maior nas comunidades de Mamuna e Itamatatiua. Os falantes estariam reinterpretando este final verbal $\{-0\}$, entendendo este morfema como uma marcação de plural verbal. Uma pista que leva a essa interpretação seriam os contextos com verbos de segunda conjugação, conforme em (79), e irregulares, como em (80) - explorados no próximo capítulo —, que, embora não sejam quantitativamente elevados (correspondem a $6 \%$ do total), podem deixar mais evidente essa ampliação desse plural intermediário, seja em termos quantitativos seja em termos qualitativos.

(79) aí todo mundo calado aí ela disse assim ... "ah mas vocês são muito calado ... VOCÊSS num DIGO nada" — MJLP/MMN

(80) [Falando sobre as pessoas que vão à Itamatatiua fazer pesquisa de campo] agora mesmo tem uma aqui da ...da Grécia ... ela tá até aqui ... hospedada ela tá fazendo uma pesquisa também ... é a K. ... ela tá pa Pinheiro ... aí ELES VENHO ... FAÇO muita pesquisa por aqui - ENJ/ITM

Essa redução do ditongo final átono e posterior reinterpretação do final $\{-\mathrm{O}\}$ como marcador de plural verbal poderiam ter sido frutos do contato linguístico com as línguas africanas trazidas para o Brasil durante o período colonial. Essa possibilidade de análise será explorada no próximo capítulo.

ou não se é, de fato, a mesma forma verbal para a primeira e terceira pessoa. Contudo, conforme apontado no início da tese, este tipo de análise será empreendida em trabalhos futuros.

${ }^{8}$ Para mais detalhes sobre essa questão, consultar os trabalhos já citados de Duarte (1993, 2000); Duarte (2003); Cyrino \& Duarte (2000); Buthers \& Duarte (2012), entre outros. 


\subsection{Considerações do Capítulo}

Neste capítulo apresentei a noção de marcação de plural intermediária, com a terminação verbal transcrita ortograficamente como [o], que estaria entre a total ausência de um morfema de plural no verbo e a presença do

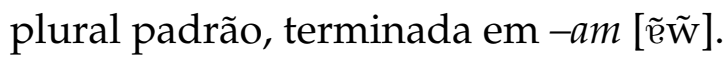

Grande parte dos estudos sobre a concordância verbal apresentam esses verbos de final reduzido de modo superficial, sem aprofundar a análise, ora concatenando com o plural não padrão (Almeida, 2006a e Welchen, 2015), ora analisando juntamente com as ocorrências de plural padrão (Silva, 2005; Lucchesi et al., 2009 e Araujo, 2014).

Nesta tese, considero e analiso essa marcação separada das demais, uma vez que nas comunidades quilombolas alcantarenses esses verbos com a vogal final posterior representam a maior parte dos dados. Seria um erro conceber e analisar esse tipo de marcação tanto com os dados de plural não padrão, porque essa terminação $\{-0\}$ veicularia plural, quanto com o plural padrão, pois, embora possa veicular uma noção de número, não se pode dizer que seja igual à ocorrência padrão.

Para os trabalhos que consideram essa redução final como influência das línguas africanas, os autores não explicitam como se deu essa influência (Raimundo, 1933), e alguns afirmam que teria se dado pois "as línguas africanas desconheceriam as vogais nasais" (Castro, 2001) e por este motivo

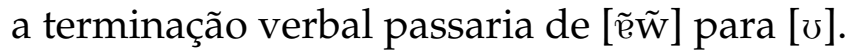

Apresentei a marcação intermediária de plural com verbos conjugados no tempo passado, evidenciada tanto no pretérito perfeito quanto no imperfeito. Ao que parece, não há restrição quanto ao tipo de sujeito, e acontece com pronomes pessoais 'eles/elas' com referência determinada; pronomes pessoais 'eles / elas' com referência vaga ou indeterminada; nomes substantivos no singular com um ou mais determinantes no plural; nome substantivo no plural; outros pronomes; numeral no plural; dois ou mais núcleos; sujeito nulo e sujeito com pronome relativo 'que', e não difere de outros trabalhos que apresentam este tipo de ocorrência, predominantemente, com verbos no passado.

Os verbos no presente evidenciam um contexto que não é muito comum para este tipo de redução. No que concerne ao tipo de sujeito, não foram encontrados dados com numeral no plural, dois ou mais núcleos, sujeito nulo e sujeito com pronome relativo 'que'. A maior percentagem, tanto com verbo conjugado no passado quanto com verbo conjugado no presente, se deu com o pronome eles/elas, independentemente se de referência definida ou vaga e indeterminada. No entanto, os dados com esse tipo de sujeito representam a maior parte das ocorrências no geral, o que torna, de fato, este resultado esperado. 
Foi possível ver que, quando no presente, a forma verbal se confunde com a da primeira pessoa do singular, o que torna cada vez mais necessária a presença do pronome pessoal, para que não haja prejuízo de interpretação.

Essa marcação intermediária de terceira pessoa do plural das comunidades alcantarenses difere da de outras comunidades quilombolas, como Helvécia e Cinzento, na Bahia, São Miguel dos Pretos, no Rio Grande do Sul e Caiana dos Crioulos, na Paraíba, tanto em termos quantitativos quanto em termos qualitativos. Além de, como já observado, ocorrer em maior número nas comunidades de Mamuna e Itamatatiua, dá-se em contextos mais diversificados, com verbos no presente, verbos de segunda conjugação e verbos irregulares.

Possivelmente este final reduzido possa ser resultado do contato das línguas bantas com o português brasileiro em Alcântara durante os séculos XVIII e XIX, lembrando que o Maranhão foi uma sociedade de escravização tardia, recebendo as últimas "levas" de africanos trazidos para cá em condição de escravizados e os quilombos se formaram com mais intensidade no decorrer do século XIX. Essa formação recente faz com que os falantes das comunidades alcantarenses sejam descendentes próximos dos negros escravizados ou ex-escravizados que formaram essas comunidades, pertencendo à segunda ou à terceira geração, e poderiam carregar maiores vestígios desse contato.

No próximo capítulo apresento uma proposta para este contato, formador de um banco de traços que poderia explicar a marcação intermediária de plural das comunidades de Mamuna e Itamatatiua e o porquê de ela poder ser considerada diferente da de outras comunidades quilombolas.

Explorarei igualmente os contextos que corroboram a hipótese que será apresentada, como verbos conjugados no presente, verbos de segunda conjugação, verbos irregulares e a ocorrência desse plural com sujeitos singulares. Ao que tudo indica, não parece ser apenas um condicionamento fonológico que resulta na redução do ditongo nasal átono final, mas há, provavelmente, outros fatores envolvidos que tornam inclusive a marcação intermediária de plural tão abrangente nessas duas comunidades. 


\section{Capítulo 7}

\section{Reanálise da marca de concordância da 3PP}

Conforme apontei no final do capítulo anterior, a marcação intermediária de terceira pessoa do plural que ocorre nas comunidades alcantarenses pode ser consequência do contato do português com as línguas bantas no período colonial. Os falantes dessas comunidades, por meio de um processo fonológico de redução do ditongo nasal átono final da termina-

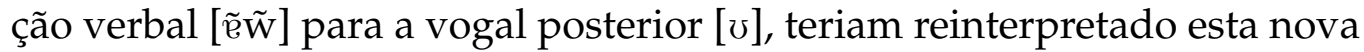
terminação como morfema de marcação de plural de terceira pessoa.

Essa reanálise poderia ser atestada por meio de contextos nos quais ela não seria prevista para o português, como em verbos de segunda conjugação e verbos irregulares, e de contextos nos quais essa marcação não é comum para o PB, como verbos conjugados no presente.

\subsection{Reinterpretação da marcação intermediária}

Nas variedades populares de português, a ausência de marcação de plural no verbo é superior à ocorrência desta marca e isso coloca em questão a própria noção de concordância (Corbett, 2000) e a maneira com que a língua explicita os marcadores da flexão de concordância.

A morfologia seria o pré-requisito para a concordância sintática, mas a morfologia do alvo, no caso, o verbo, não precisaria necessariamente realizar esses traços em algumas línguas. Nas línguas bantas, por exemplo, existem prefixos nominais e prefixos verbais no infinitivo, que são, em geral, ausentes nas outras formas verbais. Nas línguas crioulas, por exemplo, especialmente as de base portuguesa, os verbos não apresentam flexões. 
Nesse sentido, a ausência de marca de plural no verbo apresenta um padrão de concordância singleton, em que exibe apenas uma marca explícita, de pessoa e número, no pronome sujeito, como em eles come, semelhante ao encontrado no sintagma nominal, por exemplo, como em concordância do tipo as casa. Esse paradigma verbal, no qual a marca de número é expressa apenas no pronome, realizaria a distinção entre a $1^{a}$ e as demais pessoas pronominais, estas últimas apresentando uma forma verbal identificada à da $3^{a}$ pessoa do singular ${ }^{1}$.

$\begin{array}{lll}\text { Presente } & \text { Pret. Perf. } & \text { Pret. Imperf. } \\ \text { eu estudo } & \text { eu estudei } & \text { eu estudava } \\ \text { você estuda } & \text { você estudou } & \text { você estudava } \\ \text { ele estuda } & \text { ele estudou } & \text { ele estudava } \\ \text { a gente estuda } & \text { a gente estudou } & \text { a gente estudava } \\ \text { vocês estuda } & \text { vocês estudou } & \text { vocês estudava } \\ \text { eles estuda } & \text { eles estudou } & \text { eles estudava }\end{array}$

O paradigma verbal acima é o apresentado pelos diferentes autores que observam a tendência do português brasileiro para uma redução do paradigma pronominal e verbal. De acordo com esses autores (Lucchesi et al., 2009; Castro, 2001; Holm, 2011, entre outros), nas formas de terceira pessoa do plural, ocorreria uma desnasalização do final verbal que se dá por influência do contato com as línguas africanas.

Silva et al. (2012) apontam para este fenômeno, fonologicamente, não apenas como desnasalização, mas como uma redução do ditongo nasal átono final. Neste caso, ocorreria a queda do glide e a manutenção da vogal central.

Essa redução, apontada por alguns autores como desnasalização e por outros como redução de ditongo átono final, pode ser observada, em algumas comunidades, em palavras como viagem, coragem e homem, nas quais são produzidas como viage, corage e home.

A redução dos ditongos nasais átonos em terceira pessoa do plural nas comunidades de Alcântara difere das apresentadas acima, uma vez que o ditongo átono nasal final [ $\tilde{e} \tilde{w}$ ] é reduzido, na maior parte dos dados, para uma vogal posterior [ $v$ ]. Nessas comunidades, a morfologia de concordância verbal não está totalmente ausente, o que ocorre é uma redução fonológica sem a perda da marca morfológica de plural e, nesse sentido, uma terceira forma emerge no paradigma verbal.

\footnotetext{
${ }^{1}$ Paradigma do pretérito perfeito baseado em Holm (2011).
} 
O fenômeno de redução de ditongo nasal pós-tônico final também tem sido estudado em uma perspectiva fonológica por autores como Battisti (1997, 2002), Bopp da Silva (2005), Silva et al. (2012), Soares (2015), entre outros.

Em linhas gerais, as formas verbais padrão de terceira pessoa do plural no português possuem um fator tipicamente associado a elas que tem grande impacto na concordância e é relacionado à estrutura fonológica dessas formas (Mota, 2015): -/vogaltemáticaN/, em que /N/ representa um autossegmento flutuante (Mateus \& d'Andrade, 2000) não realizado como consoante nasal, mas que nasaliza a vogal anterior, dando origem a um ditongo fonético átono. Esse ditongo é formado então, como resultado de afixação morfológica flexional:

\section{- estudam}

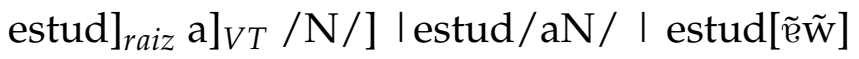

\section{- estudavam}

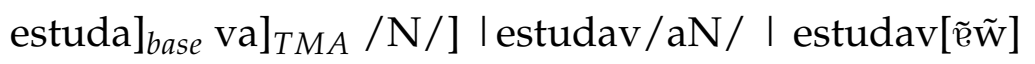

As formas padrão de terceira pessoa do plural terminam, então, com

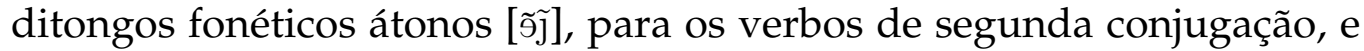
[ $\tilde{\mathrm{e}} \tilde{W}]$, para os verbos de primeira conjugação, sendo estes últimos os mais produtivos na língua (Wetzels, 2000).

Conforme dito anteriormente, / N/ é um autossegmento flutuante que se ancora na rima silábica. Os resultados desse processo são, primeiro, a nasalização da vogal precedente (vogal temática ou parte da TMA tempo, modo e aspecto), que é quase sempre não acentuada, e depois uma

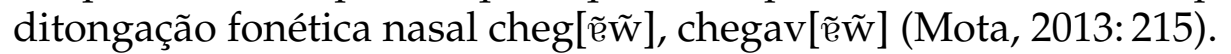

Esse ditongo formado é derivado, não lexical. O que ocorreria, na sua formação, seria um processo de assimilação, em que $\mathrm{N}$ se expande para a vogal e adquire os traços articulatórios da vogal por ele nasalizada. Em final de palavra, o processo de assimilação seria mútuo: $\mathrm{N}$ nasaliza a vogal e esta cria o glide homorgânico (Battisti \& Vieira, 2001: 168).

Na redução do ditongo nasal final átono, há um enfraquecimento da nasal e a consequente queda da semivogal. Após esse processo de apagamento e queda do glide, ocorre o alçamento da vogal, regra de neutralização do sistema vocálico do PB (posição átona final) (Bisol, 1989 em Soares, 2015),

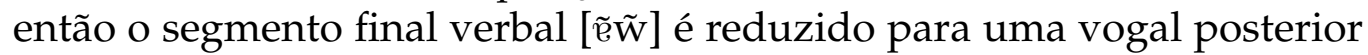
[ซ], sem nasalização. Esta regra pode ser representada da seguinte forma: 


$$
/ \tilde{\mathrm{Q}} \tilde{\mathrm{W}} / \longrightarrow[\mho] \_\# \#
$$

Dentro da perspectiva fonológica, a realização de ditongos nasais átonos também é vista como variável, ora ocorrendo a redução fonológica sem nasalização (órgu, falaru, homi, onti), ora ocorrendo o ditongo nasal (órgão, falaram, homem, ontem). Esses ditongos, quando tônicos, não sofrem qualquer redução (irmão) (Battisti, 2002). Essa variação é condicionada tanto por fatores linguísticos quanto extralinguísticos. Battisti (1997) afirma que a motivação para essa redução é prosódica, uma vez que seria a atonicidade da sílaba que desencadearia a realização variável dos ditongos.

Ao considerar a redução dos ditongos nasais pós-tônicos, (Silva et al., 2012: 285) apresentam o seguinte paradigma verbal:

\begin{tabular}{l|l|l} 
Presente & Pret. Perf. & Pret. Imperf. \\
eu cantu & eu cantei & eu cantava \\
você canta & você canto & você cantava \\
ele canta & ele canto & ele cantava \\
a gente canta & a gente canto & a gente cantava \\
vocês canta & vocês cantaru & vocês cantava \\
eles canta & eles cantaru & eles cantava
\end{tabular}

Os tempos verbais presente e pretérito imperfeito coincidem com o paradigma verbal apresentado anteriormente. O primeiro opondo a forma verbal da primeira pessoa à das demais e o pretérito imperfeito apresentando a mesma forma verbal para todas as pessoas pronominais.

O pretérito perfeito, no entanto, mostra um paradigma diferente. Neste tempo verbal, há três formas verbais distintas: a da primeira pessoa; a de segunda e terceira pessoas do singular e do pronome gente; e a forma de segunda e terceira pessoas do plural.

Para Silva et al. (2012), a redução para uma vogal central nos tempos presente e pretérito imperfeito é explicada por um nivelamento analógico e uma redução fonética. No pretérito perfeito também ocorre um nivelamento analógico, porém, associado aos pronomes vocês/eles(as). Isto se deveria ao fato de nas $2^{a}$ e $3^{a}$ conjugações os pronomes você, ele/a e a gente terminarem com $[\mathrm{u}]$, em ditongo: vendeu ou partiu. Então, os pronomes vocês e eles(as) adotariam, também, a terminação [u]: venderam > venderu; partiram > partiru. Ou seja, as $2^{a}$ e $3^{a}$ conjugações apresentariam o "nivelamento analógico de regularização das formas verbais para todas as pessoas verbais como [u] átono final" (pg. 291).

Nesse sentido, a terminação [u] átona final seria a forma adotada no nivelamento analógico de regularização das formas verbais de $2^{a}$ e $3^{a}$ pessoas 
de plural em todas as conjugações verbais. A organização gramatical operaria, desse modo, em redes interconectadas com a semântica, na expressão do número verbal, e com a fonética, na redução segmental em posição átona, contribuindo para a tendência de simplificação do paradigma verbal no PB. Diante disso, os autores também considerariam a terminação [u] átona final como uma marca morfológica de número verbal.

É possível notar em estudos como o de Silva et al. (2012), analisando dados de Belo Horizonte, ou como o de Gomes et al. (2013), analisando dados do Rio de Janeiro, entre outros, que a redução do ditongo nasal pós-tônico final é encontrada, basicamente, em verbos no pretérito perfeito. Pensando em marcação de número no verbo, apenas esse tempo verbal veicularia uma morfologia de concordância, enquanto os demais apresentariam a marca de plural apenas no pronome sujeito.

Essa redução do ditongo nasal átono final encontrada nas comunidades alcantarenses, contudo, apresenta um outro paradigma verbal com a redução do ditongo nasal pós-tônico final não apenas no pretérito perfeito, mas também no presente do indicativo e no pretérito imperfeito. Diante disso, todas as formas de terceira - e também de segunda - pessoa do plural apresentariam uma marca de concordância no verbo, a despeito do tempo verbal.

\begin{tabular}{l|l|l} 
Presente & Pret. Perf. & Pret. Imperf. \\
eu estudo & eu estudei & eu estudava \\
tu estudas & tu estudastes & tu estudavas \\
você estuda & você estudou & você estudava \\
ele estuda & ele estudou & ele estudava \\
a gente estuda & a gente estudou & a gente estudava \\
vocês estudo & vocês estudaro & vocês estudavo \\
eles estudo & eles estudaro & eles estudavo
\end{tabular}

Nestas comunidades, ao que parece, surge, ao lado da marcação padrão e da marcação não padrão, uma terceira forma, reduzida, para expressar o plural, porém ela ocorre de modo mais amplo que as outras duas formas e é aplicada em todos os tempos verbais, sem distinção. É a marcação intermediária de plural.

Diferentemente da análise que aponta para a redução do paradigma verbal que opõe a forma de primeira pessoa às demais, apresentando basicamente duas formas de flexão verbal, e considerando que a marcação intermediária é a de maior ocorrência, o paradigma verbal das comunidades de Alcântara seria composto, basicamente, de três formas nos tempos verbais presente e pretérito perfeito e duas formas no pretérito imperfeito. 
Nos dois primeiros tempos verbais há uma forma para a primeira pessoa do singular; uma forma para o singular, contemplando segunda e terceira pessoas e o pronome a gente; e outra forma para o plural, também contemplando a segunda e a terceira pessoas. No pretérito imperfeito há uma forma diferente para o plural, na segunda e terceira pessoas, oposta às demais.

Importante observar que os paradigmas apresentados anteriormente contribuem com a tendência de simplificação do paradigma verbal canônico, considerado pela gramática normativa, observada para o português brasileiro (Duarte, 1993, 2000, 2003; Cyrino \& Duarte, 2000; Buthers \& Duarte, 2012, entre outros). O paradigma das comunidades alcantarenses, contudo, apresenta uma complexificação, se comparado ao paradigma da norma popular, como apresentado em Holm (2011), Silva et al. (2012), entre outros.

Nas comunidades de Mamuna e Itamatatiua, os verbos no presente apresentam uma questão para a análise, pois a a forma verbal de terceira pessoa do plural confunde-se com forma verbal de primeira pessoa e, conforme já mencionado, isso aponta para a necessidade cada vez mais forte de marcação pronominal na fala dessas comunidades.

Diante do exposto até o momento, essa redução de ditongo nasal átono final para vogal posterior nas comunidades quilombolas de Alcântara, que considero na presente tese como marcação intermediária de plural, não parece ser, nessas comunidades, apenas um fenômeno de redução fonológica, embora possa ter-se iniciado deste modo. Envolve questões morfológicas, na marcação de plural, e sintáticas, apontando para a preferência pela marcação pronominal.

Nos dados do português escrito por africanos no século XIX também é possível encontrar a redução do ditongo nasal pós-tônico final (Oliveira, 2008). Em todas as 27 ocorrências do corpus da Sociedade Protetora dos

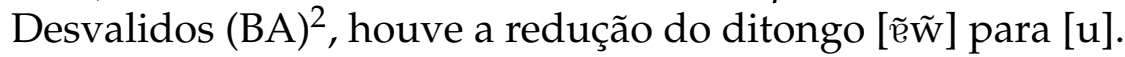

A redução de ditongos verbais finais apresentou-se em maior número, com exemplos do tipo: Asigno (assinam), asinaro (assinaro), Comparicero (compareceram), dexaro (deixaram), direberraro (deliberaram), disero (disseram), Fartaro (faltaram), foro (foram), gastaro (gastaram), entre outros (Oliveira, 2008: 166). É possível observar que, com exceção de assinam, os demais verbos encontram-se no pretérito perfeito, redução que ocorre

\footnotetext{
${ }^{2}$ A Sociedade Protetora dos Desvalidos foi fundada em 1832, em Salvador (BA). Os dados analisados por Oliveira (2008) são compostos por 290 documentos escritos ao longo do século XIX, no âmbito dessa irmandade negra. Mais detalhes sobre os dados e outros fenômenos estudados, ver Oliveira \& Lobo (2009).
} 
comumente em outras comunidades, como é o caso do Rio de Janeiro, por exemplo (Gomes et al., 2013).

O autor observa, para a explicação dessas ocorrências, que os africanos transpuseram fenômenos da fala na escrita. Não deixa claro, porém, o porquê da redução desse e de outros ditongos apresentados no referido trabalho. Observa que a monotongação ocorria já no latim vulgar (Oliveira, 2008: 157) e ainda que a redução de ditongos é atestada nas variedades portuguesa, brasileira e angolana do português, no entanto, parece não atribuir a redução da escrita dos africanos no século XIX a nenhuma motivação, se das línguas maternas dos escritores ou se do próprio português.

A hipótese para as comunidades de Alcântara seria a de que esse final $[\mho]$, transcrito ortograficamente como $\{-\mathrm{O}\}$, teria sido reinterpretado pelos falantes dessas comunidades como um morfema plural de terceira pessoa. Essa reinterpretação teria feito com que essa marcação fosse generalizada para todas as ocorrências de terceira pessoa do plural, como verbos no presente e verbos nos quais o processo fonológico de redução final [v] não poderia ocorrer no português brasileiro, como verbos de segunda conjugação, por exemplo, que serão apresentados na próxima seção.

\subsection{Marcação com verbos de segunda conjugação e com verbos irregulares}

A marcação intermediária de plural em verbos da $2^{a}$ conjugação pode tornar a proposta de reinterpretação do final $\{-0\}$ como um morfema de marcação de plural mais clara.

Ao que parece, essa reanálise do final $\{-0\}$ como marcador de plural de terceira pessoa, a partir das formas verbais regulares, teria se generalizado a tal ponto que fez com que esse morfema ocorresse inclusive em contextos nos quais essa redução não seria fonologicamente prevista, como verbos terminados em -em, conforme exemplo (1).

(1) [Falando do atendimento dos hospitais, pois na cidade mais próxima os atendentes se recusam, algumas vezes, a atender o pessoal da comunidade] eles ... eles só quere atender do Goiabal Raimundo Sul ...p pra lá pa Alca/pa Bequimão ... agora Itamatatiua ELES não QUERO pra lá ... quer Alcântara — MAJ/ITM

À semelhança de (1), o verbo mexer também recebeu a terminação verbal $\{-o\}$ quando conjugado na terceira pessoa do plural: 
(2) há aí uma grande diferença ... uma coisa que ELES USO normalmente ...e têm como adquirir ...tá enten/ e vive a vida DELES ... num MEXO com ninguém - MJLP/MMN

Caso esse processo de marcação intermediária do plural de terceira pessoa das comunidades analisadas fosse apenas um processo fonológico de redução do ditongo átono final, tanto o verbo querer (querem) quanto o verbo

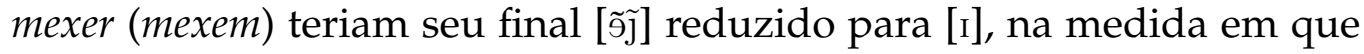
ocorreria a queda do glide e o alçamento da vogal.

Contudo, não é o que ocorre nos dados das comunidades alcantarenses, uma vez que esses verbos são marcados com o final $\{-0\}$, como é possível notar pelos exemplos em (1) e (2). Porém, fonologicamente, não seria possível ocorrer o alçamento da vogal [e] para a vogal posterior [v], logo, conforme apontado anteriormente, esse não é apenas um fenômeno de redução fonológica de ditongos nasais átonos finais.

De acordo com a hipótese levantada, a de reinterpretação desse final $\{-o\}$ como morfema de plural de terceira pessoa, os verbos de segunda conjugação não poderiam terminar em [I], pois além de não se tratar apenas de um fenômeno fonológico, a terminação [I] não corresponderia à marcação de terceira pessoa do plural dessas comunidades, o morfema $\{-0\}$.

Significativo mencionar novamente o fato de as formas verbais quero e mexo serem homófonas à forma de primeira pessoa do singular dos respectivos verbos. Os exemplos com o verbo fazer, em (3), (4) e (5), tornam o caminho dessa reanálise ainda mais claro.

(3) tirando o barro assim com a mão ... fazi/tapava tudinho ao redor e agora abria os buraco assim pa tirar o barro ... pa tirar o barro do fundo ... pa trazer pa fazer a louça como ELAS FAÇO aqui $\mathrm{MJ} / \mathrm{ITM}$

(4) [Falando de uma pesquisadora caboverdiana que passou um tempo na comunidade.] pra mim parecia ... ela ... ELES FAÇO louça pra lá que nem a gente ... tudo dela era assim que nem a gente até o couso dela era de J. não era? — IENJ/ITM

(5) a igreja tamo apontando né ... faz a missa que ELES FAÇO a missa é aqui em casa - CMDS/MMN

Na sequência de (3) a (5) vemos a marcação intermediária com o verbo fazer. Este verbo, quando na terceira pessoa do plural, possui a terminação em (fazem), assim como os verbos querer e mexer apresentados anteriormente. Outra vez, se o fenômeno em questão fosse apenas a redução desse ditongo 


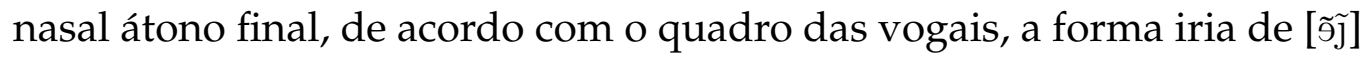
para a forma reduzida [I]:

(6) ?ELAS FAZI muita louça aqui.

Esta forma verbal, embora fonologicamente possível, não parece ser aceitável para este verbo, pois, seguindo a lógica de reanálise de $\{-0\}$ como morfema de plural de terceira pessoa, [I] não veicularia esta informação, logo, não poderia ocorrer nesse contexto. É possível perceber que não é uma questão de condicionamento fonológico, pois as consoantes que precedem a vogal final são diferentes nos verbos querer, mexer e fazer, logo, não é o ambiente fonológico que está condicionando a ocorrência de $\{-0\}$ final.

Reforçando que a questão aqui não é apenas uma redução da terminação verbal do plural, mas uma generalização da forma reduzida [ $\mho$ ] para o final plural dos verbos na terceira pessoa.

Ao que parece, a saída encontrada pelos falantes para regularizar a marcação intermediária no presente para o verbo fazer foi "torná-lo regular", escolhendo uma forma na qual a terminação $\{-0\}$ pudesse ocorrer e, assim como os demais verbos com marcação intermediária no presente, como resultado, a terceira pessoa do plural no presente fica homófona à marcação de primeira pessoa do singular, mesmo para os verbos irregulares.

Entendo esta regularização tanto da forma verbal (verbo irregular / regular) quanto da marcação intermediária, ou seja, a reanálise verbal da marcação intermediária se tornou tão ampla que até mesmo verbos que não se encaixam na redução fonológica do ditongo final em [v] estão sendo modificados para que possam receber esta terminação verbal.

O dado em (7) também reforça a hipótese de regularização. Neste exemplo é possível observar a ocorrência do final da marcação de terceira pessoa do plural -am, no tempo presente, no verbo irregular fazer, ou seja, ao invés de a ocorrência da marcação de CV ser eles fazem, no indicativo, o que seria esperado neste contexto, os falantes realizam eles façam, coincidente à forma subjuntiva, mostrando uma alternância com a forma reduzida eles faço.

(7) verdade porque ... ELES FAÇAM muita coisa é ... foi jogado muito dinheiro fora (mermã) ... muito dinheiro fora ... tem muito dinheiro perdido no meio daquele ... daquela sucata que tá ali - MGS/MMN

Lembrando que essa manutenção da base verbal regular se dá apenas quando o verbo ocorre na terceira pessoa do plural no tempo presente, 
pois quando o verbo encontra-se no pretérito imperfeito, por exemplo, a forma não apresenta problemas para a terminação verbal reduzida, uma

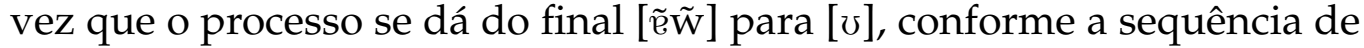
dados de (8) a (12). Lembrando que este também é um contexto distinto das comunidades que apresentam a redução do ditongo nasal pós-tônico final (Gomes et al., 2013; Silva et al., 2012).

(8) lá (no Pará) eles trabalha com cerâmica e a gente foi conhecer também como é que ELES FAZIO as panela - ACJ/ITM

(9) aqui tinha um casal de gente era muito unido aí ELES FAZIO essa festa (da Nossa Senhora da Conceição) junto - CMDS/MMN

(10) eu acho que foi assim porque ... e surgiu a cerâmica [... ] e eles tavo fugido alguém sabia mexer com cerâmica ... né? ... aí queimava (rocha) no tempo ... não era? ELE FAZIO ... tinha o barraquinho né? ... e alguém sabia - NJ/ITM

(11) ninguém fazia casa de alvenaria pra num ter que deixar pa trás ... porque ELES DIZIO que ia sair no outro ano marcava a área marcava tudo ... e nessa época as pessoas num tinha conhecimento dos seus direito - MJLP/MMN

(12) ES (a Base) num QUERIO que a comunidade daqui fosse nem na praia fazer a pescaria - NDS/MMN

Esta manutenção da base regular para o acolhimento deste morfema plural de terceira pessoa no tempo presente, que coincide com a forma verbal de primeira pessoa do singular, ocorre também em outros verbos, como o irregular dizer, (13) e (14), e os verbos vir, em (15), e ter, em (16) e (17).

O verbo dizer segue o mesmo princípio dos verbos fazer, querer e mexer - a redução fonológica da terminação verbal levaria à forma dizi, o que não parece ser aceitável para a fala dessas comunidades, então, a solução encontrada seria utilizar a forma coincidente à da primeira pessoa do singular para que a vogal final de plural de terceira pessoa pudesse ocorrer.

(13) aí o PESSOAL DIGO assim ... aí ele vai lá no sindicato e diz assim "eu sou lavrador" ... mas umbora ver a roça de seu fulano ... chega lá ... “onde é que tá a roça? tu né lavrador?" né ... ma rapaz ... aí num tem a roça - ACJ/ITM

(14) aí todo mundo calado aí ela disse assim ... "ah mas vocês são muito calado ... VOCÊS num DIGO nada" - MJLP/MMN 
Tanto o verbo vir quanto o verbo ter não apresentam qualquer alteração morfológica quando na terceira pessoa do plural, mas, neste caso, considerando a hipótese de que o final $\{-0\}$ teria sido reinterpretado como marcador de plural na terceira pessoa e que, nessas comunidades, a morfologia de plural verbal é relevante, esses verbos não estariam veiculando, para os falantes dessas comunidades, a ideia de plural. Então, assim como nos demais dados que estabelecem concordância com a terceira pessoa do plural no tempo presente, a solução encontrada foi utilizar uma forma coincidente à da primeira pessoa do singular, como é possível observar nos dados (15), (16) e (17).

(15) aí ELES VENHO ... faço muita pesquisa por aqui — ENJ/ITM

(16) se esses deputado ... com o governo cumprisse ... se fizesse uma lei ... firme pra ... pa nego ter medo ... acabava metade dessa valentia ... é porque ELES não TENHO medo da lei ... ele não tenho medo da lei - RJ/ITM

(17) [Falando sobre o atendimento médico em Bequimão.] eu disse "mas isso num tem nada a ver né ... não tem nada a ver ... aí" ... de de coisa ... ele ELES TENHO preconceito com a gente ... pa num ir pra lá ... que tem que ir é pa Alcântara - MAJ/ITM

Interessante notar que, embora não tão amplamente quanto nas comunidades quilombolas alcantarenses, este tipo de marcação também ocorre no português falado em Moçambique:

Há MUITAS ALUNAS fora da escola ou porque não TENHO dinheiro de matrícula.

(Gonçalves \& Stroud, 1998: 128)

O que estes dados de marcação de plural verbal intermediária em contextos nos quais a redução fonológica para [v] não seria prevista vêm mostrar é que, de fato, parece ter ocorrido uma reinterpretação desse morfema final como marcador de plural de terceira pessoa, o que fez com essa marcação fosse generalizada para os demais verbos quando conjugados na terceira pessoa do plural.

Outro fator que corrobora a hipótese levantada é a manutenção da base verbal em uma forma coincidente à de primeira pessoa para acolher esse morfema final, o que pode ser observado nos verbos dizer, fazer, ou ainda a inserção desse morfema em verbos que não possuem distinção na marcação de terceira pessoa do plural, como ter e vir, por exemplo. Estes verbos reforçam a hipótese levantada, pois, uma vez que esse morfema 
é veiculador da informação de plural na terceira pessoa, todos os verbos deveriam recebê-lo, logo, a base verbal de primeira pessoa é mantida para que se possa acolher essa terminação, no caso dos verbos irregulares, ou a eles é adicionado esse morfema, no caso dos verbos ter e vir.

No entanto, esse processo de "acolhimento" do morfema final com verbos no presente não gera formas novas, mas sim "toma emprestado", uma forma verbal de final $\{-0\}$ que já está disponível no paradigma verbal, a primeira pessoa do singular e, como consequência, a presença do pronome pessoal se faz cada vez mais necessária para que se distingam as pessoas verbais.

Caso os falantes dessas comunidades produzissem uma forma do tipo fazo, no verbo fazer, por exemplo, esta seria uma forma inovadora, contudo, a morfologia lexical dessas comunidades, e também do português, é conservadora. A fala dos moradores de Mamuna e Itamatatiua mantém a unidade entre o pronome e o verbo, e, o que é inovador, nas comunidades alcantarenses, é o elemento de construção, nesse caso específico, eles faço, e não as unidades constituintes.

Distintamente de outras análises que apontam para uma tendência, no português brasileiro, a uma marcação não redundante de plural que marca o número apenas no pronome sujeito, ou no determinante do sintagma nominal, os dados das comunidades alcantarenses evidenciam que, pelo menos no sintagma verbal, a informação de número no verbo ainda é importante para essas comunidades.

\subsubsection{O contato com as línguas africanas e a redução final do verbo}

Castro (2001), Lucchesi et al. (2009), Holm (2011), entre outros, indicam a perda da nasalização final dos verbos como decorrência do contato entre o português e as línguas africanas. Este fenômeno de desnasalização do final verbal tem sido amplamente atestado no PB. Os dados das comunidades de Alcântara, contudo, revelam não apenas um fenômeno de desnasalização do final verbal, mas, adicionalmente, uma redução do ditongo nasal final átono para uma vogal posterior e a manutenção de uma morfologia verbal de plural.

No Brasil, embora estruturalmente exista a discriminação racial, não há uma "fala de negros", exceto aquela associada às comunidades quilombolas. Fora das comunidades remanescentes de quilombos, a polarização existente é de ordem socioeconômica, resultante de uma discriminação social que divide a língua da camada mais pobre da população e a da camada mais 
rica. Não obstante, no período colonial e no início do século XX, havia características que eram associadas diretamente à fala dos negros.

Raimundo (1933) e Mendonça (1933), por exemplo, apontavam para essa marcação verbal final reduzida em vogal posterior como uma "fala de pretos", conforme apontado no capítulo 6, seção 6.2. A citação de Mendonça (1933: 86) é repetida aqui por conveniência:

“Temos outrossim ouvido, no Distrito Federal, a terminação am da $3^{a}$ pessoa do perfeito do indicativo soar o átono na pronúncia dos pretos e gente de sua classe: amaram ...amaro, fizeram ...fizero, disseram ... dissero" Mendonça (1933: 86).

Observe-se que era falada pelos "pretos e gente de sua classe". A escrita dos africanos no século XIX corrobora o fato de esse tipo de ocorrência ser uma característica ligada à fala dos africanos que falavam português, bem como uma influência das suas línguas maternas no português falado e escrito por eles, uma vez que, conforme Oliveira (2008) observa, eles transpunham fenômenos da fala para a escrita.

Essas ocorrências, apontadas por diferentes autores como característica da fala dos pretos ao falar português e que hoje é restrita a algumas comunidades, como em Minas Gerais e no Rio de Janeiro, por exemplo, ocorrendo de maneira mais marginal, são amplamente utilizadas nas comunidades de Alcântara e podem ser resultado do contato linguístico com as línguas africanas trazidas para cá, uma vez que eram associadas diretamente ao falar dos negros e africanos.

As línguas africanas possuem como propriedade geral, apontada por diversos estudiosos, preponderantemente, sílabas abertas e tendência a evitar ditongos e encontros consonantais (Meeussen, 1975: 2; Gilman, 1986: 41 em Heine \& Leyew, 2008: 20).

Conforme observado no capítulo 3, seção 3.3, as principais línguas transportadas para o Brasil na época da colonização foram as do tronco nigero-congolês, mais especificamente as línguas do grupo banto.

As línguas bantas são tipologicamente homogêneas e boa parte delas tem por característica, apontada também por diferentes autores, a ausência de ditongos (Heine \& Leyew, 2008; Ngunga, 2002, entre outros) e, para evitálos, realizam diversos processos fonológicos como a elisão e a assimilação, por exemplo.

Em meados do século XIX, Bleek (1862) já observava que as línguas bantas pareciam não possuir ditongos. Para Hyman (2003) as LBs restringem severamente a sequência de vogais e as vogais iniciais das bases verbais podem estar isentas dos processos de redução e assimilação aos quais as vogais pós-base estão submetidas. 
Ao realizar a descrição do quimbundo - língua que atestadamente participou do processo de formação do PB — falado na Bahia, Dias (1697: 2) também observa essas características, apontando para as sílabas abertas como, por exemplo, "Todos os nomes e verbos acabam em as vogais, $a, e$, $i, o, u[\ldots]$ " e para o processo de elisão de vogal quando da ocorrência de encontros vocálicos.

$$
\begin{aligned}
& \text { Macamba ami > Macambàmi } \\
& \text { Meus amigos } \\
& \text { Mubica üàmi > Mubicàmi } \\
& \text { Meu escravo }
\end{aligned}
$$

(Dias, 1697: 2)

Ao lado de dados como os do quimbundo, é possível dizer que alguns processos fonológicos encontrados sincronicamente em diferentes línguas bantas podem, talvez, ajudar a entender o processo de redução do ditongo átono nasal das comunidades alcantarenses e compreender de que forma as línguas africanas exerceram, no período colonial, um papel nas características encontradas na fala dessas comunidades. $O$ fato de não se ter informação exata das línguas que participaram da constituição do PB e tampouco dos traços em competição àquela época faz com que seja necessária a análise de dados sincrônicos para a reconstrução do possível banco de traços.

Isso não significa que as línguas apresentadas tenham sido as que, de fato, contribuíram para esse banco, porém, considerando que as línguas do grupo banto são fortemente relacionadas, é possível levantar a hipótese de que traços e processos semelhantes contribuíram para a constituição do banco de traços em competição existente naquela ecologia que deu origem à marcação intermediária de plural.

Conforme observado, em boa parte das LBs, quando há uma sequência de vogais, processos como elisão e assimilação costumam ocorrer. Línguas como yao, de Moçambique; do grupo xona, do Zimbábue, Moçambique e Zâmbia; do grupo soto, de Botsuana, entre outras, também exibem esses processos (Gowlett, 2003). Apresento, a seguir, dois processos que envolvem vogais. Um relacionado à centralização de vogais finais, mais suscetíveis aos processos fonológicos, conforme aponta Hyman (2003), e um processo de redução de ditongo.

Nas línguas bantas faladas no Gabão - zona B -, como tsogo, pinzi, cande, entre outras, próximo da Guiné Equatorial, porto do qual foram trazidos inúmeros africanos na condição de escravos, além dos processos comuns de elisão e assimilação, as vogais finais sofrem alguns processos 
fonológicos, entre eles a centralização das vogais não altas e baixas em final de palavra (van der Veen, 2003):

$$
\begin{aligned}
& \text { mùngòyà - mùngòyò } \\
& \text { pescoço }
\end{aligned}
$$

$$
\text { tsèyè - tsèyó }
$$

mandril

(van der Veen, 2003)

Os processos fonológicos dessas línguas reduzem consideravelmente o inventário de vogais finais. Em vez de sete vogais, geralmente são encontradas três, em final de palavra [i], [u] e [ə].

Nas línguas bantas da zona $S$, além do processo de elisão, ocorre um processo de assimilação e apagamento da vogal. As línguas da zona $S$ são essencialmente as faladas no Zimbábue, Moçambique, Botsuana, África do Sul e Lesoto, entre elas estão as línguas tonga, tsonga, tsua, venda, zulu, entre outras. Essa divisão é baseada na classificação de Guthrie (1948) para as línguas do grupo banto.

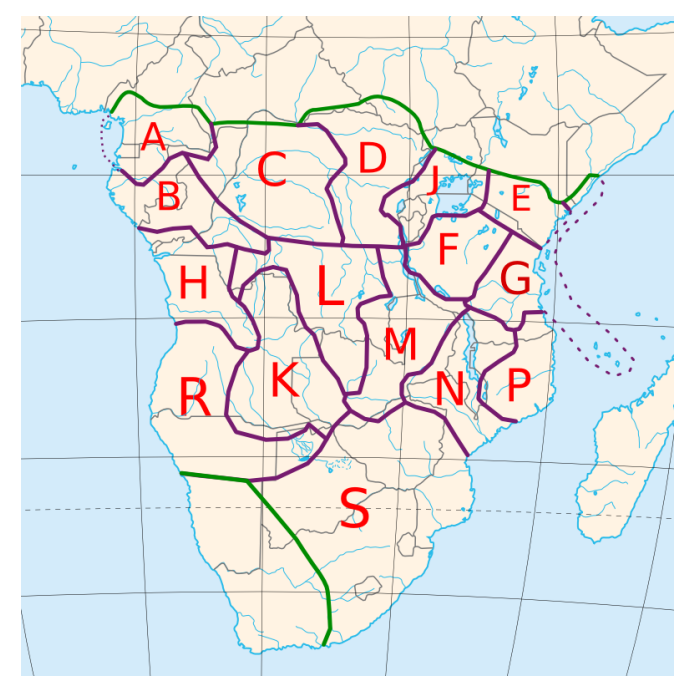

Figura 7.1: Localização aproximada das zonas geográficas de acordo com a classificação de Guthrie. Fonte: https://en . wikipedia.org.

Observem-se os dados da língua zulu (Gowlett, 2003):

$$
\begin{aligned}
& \mathrm{a}+\mathrm{i}>\mathrm{e} \longmapsto \text { ṇénł̧ùu (e uma casa) < *na } \\
& \text { (24) } \quad \mathrm{a}+\mathrm{a}>\text { an } \longmapsto \text { ṇàmánł̧à }(e \text { força })<\text { *ṇa-a-ma-nł̧a }
\end{aligned}
$$

${ }^{3} \mathrm{O}$ asterisco indica que esta é uma forma reconstruída. 


$$
\mathrm{a}+\mathrm{u}>\mathrm{o} \longmapsto \text { ṇòmúnt'ù (e uma pessoa) < ṇa-u-mu-nt'u }
$$

(Gowlett, 2003)

Nas línguas do grupo B ocorrem diversos processos fonológicos em vogais finais, especialmente átonas, e nas línguas do grupo $S$ o processo fonológico envolve a redução de uma sequência de vogais. No processo exemplificado pelos dados da língua zulu, ocorre uma assimilação entre as vogais, ocasionando abaixamento da vogal alta e levantamento da vogal central.

Importante observar que, no português brasileiro, a redução de ditongos se dá nas sílabas finais átonas, que estão mais propensas ao processo de redução do que as sílabas acentuadas. Não se vê processo de redução de ditongos em palavras como mãe, pão e irmão, por exemplo. Contudo, observa-se em palavras do tipo chaveiro, dinheiro e cadeira, nas quais esses ditongos são amplamente reduzidos no português brasileiro.

Nesse sentido, os processos fonológicos utilizados para evitar ditongos das línguas africanas, presentes no banco de traços formado durante $o$ contato linguístico, teriam exercido influência no português brasileiro, em especial em ditongos átonos e nos ditongos nasais átonos finais das comunidades de Mamuna e Itamatatiua.

Diante disso, não seria fortuito o fato de essa redução ser presente em dados de Minas Gerais (Silva et al., 2012), por exemplo, onde houve grande presença de africanos na época da mineração no Brasil colonial, no século XVIII. Os autores que estudam a redução de ditongo na fala mineira apontam, inclusive, para uma segunda forma de marcação de plural no verbo no paradigma verbal do pretérito perfeito, conforme apresentado na seção 7.1, acima. Tampouco o fato de esse tipo de ocorrência ter sido relacionado diretamente à fala dos pretos nos estudos sobre a influência das línguas africanas no PB.

Como explicitado no capítulo 3, subseção 3.1.1, na perspectiva teórica adotada, o contato linguístico e a reestruturação oriunda desse contato é consequência tanto da ecologia interna quanto da ecologia externa. A interação dessas duas ecologias poderia esclarecer não apenas as causas das mudanças linguísticas como também o motivo pelo qual um determinado fenômeno se espalha.

A ecologia interna prevê que entram em competição variantes de uma forma particular, estruturas ou regras coexistentes. Nesse sentido, as regras fonológicas amplamente utilizadas nas línguas bantas como um meio de evitar encontros vocálicos estariam presentes no banco de traços formado pelas línguas em contato na época de formação dessas comunidades.

Esses traços das diferentes línguas estariam em competição na medida em que alguns fatores das ecologias interna e externa favorecem ou não 
alguns deles. A escolha de uma dada característica seria restringida, então, por essas ecologias. A externa impõe um ranking particular de variantes ao qual as escolhas feitas pelos falantes são sensíveis. Lembrando que não são escolhas conscientes.

Essa característica particular será promovida ou desencorajada por um determinado grupo socioeconômico. Em cenários informais, por exemplo, onde variedades vernaculares são faladas, características não padrão são normalmente favorecidas sobre suas contrapartes padrão (Mufwene, 2008).

É possível levantar a hipótese de que, nas comunidades de Alcântara, adicionalmente aos processos fonológicos para evitar encontro de vogais existentes no banco de traços, a ecologia externa teve grande importância para a manutenção dessa marcação de plural com final reduzido, bem como para a sua expansão a outros contextos.

Na perspectiva de contato adotada (Mufwene, 2001, 2008), a ecologia externa exerce papel na manutenção ou desaparecimento de determinada língua ou de uma dada característica, na medida em que há condições socioeconômicas particulares que podem favorecer ou não o uso de uma língua ou característica particular.

O que teria impedido a emergência de um crioulo no Brasil, por exemplo, em contraposição aos cenários em que eles surgiram, teria sido a segregação racial instituída nestes últimos ambientes, em contraste a uma maior interação entre os europeus e não europeus na época de formação do vernáculo colonial aqui no Brasil, sem esquecer que essa maior interação não implica que ela tenha sido isenta de violência.

Considerando o contexto sócio-histórico de formação das comunidades alcantarenses apresentado no capítulo 4, é possível dizer que a qualidade do contato nessas comunidades teria sido de outra ordem, se comparada a comunidades quilombolas de outras regiões do país, até mesmo de outras localidades do Maranhão, levando em conta ainda o fato de as comunidades alcantarenses terem se formado mais tardiamente. Não se deve esquecer que o Maranhão é considerado uma sociedade de escravização tardia.

Além da formação recente dessas comunidades que possuem em torno de 200 anos, o fato de terem se formado a partir do abandono das terras pelos senhores trouxe, como consequência, um tipo de contato diferente daquele existente nas comunidades formadas na Bahia, por exemplo, ou mesmo das comunidades formadas mais próximas a São Luís, que viviam sob a constante ameaça das entradas e perseguições por parte dos fazendeiros. Nessas últimas, a fuga para os quilombos ou a formação destes não significava que tinham uma vida tranquila. Muitos eram capturados e levados de volta aos seus antigos donos, outros chegavam até a trabalhar 
em fazendas, mesmo depois da fuga. Sem contar que diversos quilombos eram destruídos e seus moradores mortos.

O relativo isolamento de Alcântara e dos moradores dessas comunidades os teria mantido distante de uma repressão mais efetiva por parte do governo, como as entradas, por exemplo. $\mathrm{O}$ fato de as terras terem sido abandonadas por seus antigos donos também eliminava o cenário de perseguição e captura dos fugidos que existia em outros contextos. Isso teria possibilitado um maior desenvolvimento dessas comunidades.

Como consequência, o contexto socioeconômico dessas comunidades teria feito com que essa característica da "fala dos pretos" fosse promovida e não desencorajada, o que poderia justificar o fato de essa marcação intermediária de plural ter se espalhado para os contextos distintos aos das comunidades nas quais esse tipo de marcação também pode ser atestada, conforme exposto ao longo das seções 7.1 e 7.2.

Nas ecologias em que as características de fala mais ligadas aos negros e africanos teriam sido mais repreendidas, quer por pressão social quer pela escolarização, a redução dos ditongos átonos finais para uma vogal posterior teria sido inibida e a ocorrência dessa marcação em outros contextos impossibilitada, embora, como já dito, ainda seja possível verificar esse tipo de marcação em comunidades nas quais atestadamente houve a presença de negros africanos escravizados, como Minas Gerais, por exemplo.

Nas comunidades de Mamuna e Itamatatiua observa-se, então, entre as características da marcação de terceira pessoa do plural, uma complexificação no paradigma verbal, quando comparado a outras comunidades rurais; ao invés de duas formas de marcação, atestam-se três formas verbais; uma redução do ditongo nasal átono final nos verbos de terceira pessoa do plural, independente do tempo verbal, que traz como consequência a coincidência entre a forma de terceira pessoa do plural e a forma do verbo de primeira pessoa do singular no presente do indicativo; a necessidade da presença do pronome sujeito; a manutenção de bases de primeira pessoa do singular com verbos irregulares no presente para a marcação de terceira pessoa do plural; e a inserção do morfema de plural nos verbos ter e vir.

Como Mufwene (2001: 166) observa, nenhuma diferença no processo de reestruturação do sistema linguístico pode ser clara ou exclusivamente associada a fatores da ecologia interna ou externa. Nesse sentido, considerando as ecologias interna e externa que deram origem às comunidades quilombolas de Alcântara, o que poderia ter acontecido é a aplicação, por influência do contato com as línguas africanas, dos processos fonológicos que evitam ditongos, os quais teriam levado à redução do ditongo átono final para uma vogal posterior nos verbos de terceira pessoa do plural. 
A ecologia externa teria atuado, por sua vez, na não repressão dessa característica da fala dos pretos. Diante disso, a marcação resultante desse processo de redução teria sido reinterpretada, pelos falantes dessas comunidades, como um morfema de marcação de plural de terceira pessoa e se espalhado para outros contextos, o que pode ser verificado nos verbos de terceira pessoa do plural no presente e no pretérito imperfeito, nos verbos de segunda conjugação e nos verbos irregulares, contextos nos quais essa marcação não ocorre em comunidades que tiveram uma ecologia externa distinta.

\subsection{Marcação com sujeitos no singular}

Outra marcação que ocorre nessas comunidades é a ocorrência de verbos plurais com sujeitos singulares.

A concordância verbal, em geral, é um sentido adicional de marcação de número, como no exemplo em inglês ${ }^{4}$ (26), contudo, há línguas em que a situação que prevalece é a exemplificada em (27), na qual o nome não recebe qualquer marca de plural e o que vai diferenciar o singular do plural é o verbo e, às vezes, o determinante.

(26) Those goats are eating the washing Aquelas cabras estão comendo a lavagem.

(27) Those sheep are doing nothing about it Aquelas ovelhas não fazem nada a respeito.

(Corbett, 2000: 136)

Situação semelhante à exemplificada em (27) ocorre em amele, uma língua papua que pertence ao subgrupo mandang, do tronco Nova Guiné:

(28) Dana (uqa) ho - i - a

homem 3.SG vir - 3.SG - hoje.PST

O homem veio.

(29) Dana (ale) ho - si - a

homem 3.DU vir - 3.SG - hoje.PST

Dois homens vieram.

(30) Dana (age) ho - ig - a

homem 3.PL vir - 3.PL - hoje.PST

\footnotetext{
${ }^{4}$ Mantive os exemplos no original para que o contraste ficasse mais evidente.
} 


\section{Os homens vieram.}

Nesta língua, o verbo deve concordar em número com o sujeito pelos formativos - $i-,-s i-$ e -ig- e o NP não marcado possui um referente definido. O nome pode mostrar número plural pela reduplicação dana-dana, porém é opcional. O número também pode ser indicado pela cópia pronominal, mas essa estratégia também é facultativa, como indicado pelos parênteses. Então, nessa língua, o número deve ser indicado no verbo e pode, opcionalmente, ser indicado no nome (Corbett, 2000: 137).

Em outras línguas do mundo ocorre o chamado número verbal que relaciona número de eventos, também conhecido como pluralidade ou pluracionalidade verbal. Além de eventos, os verbos pluracionais podem se referir a uma ação que é performada diversas vezes (leitura iterativa), ou em vários lugares (leitura distributiva), ou envolve vários participantes.

Cabredo-Hofherr \& Laca (2012) consideram sob o termo geral de pluralidade de eventos qualquer significado linguístico que expresse uma multiplicidade de eventos, sejam eles marcadores verbais, adverbiais ou adnominais, e usam o termo pluralidade verbal mais estritamente para a pluralidade de eventos marcada no verbo. Estes marcadores de pluralidade verbal são chamados de marcadores pluracionais (Newman, 1980) e são, em geral, reduplicativos e muito comuns nas línguas da América do Norte e no oeste africano, além das línguas dravídicas, e língua de sinais americana (Lasersohn, 1995).

É relevante observar que, em algumas línguas, mesmo que o nome não receba qualquer marca de número, isso não significa que seja uma língua que expressa a pluralidade verbal, como nos exemplos (27), (29) e (30). Nesses casos, a marcação de plural ainda se refere ao número de entidades e não de eventos.

O fenômeno da pluralidade é encontrado amplamente nas línguas da América do Norte, nas quais os marcadores de pluralidade verbal são mais produtivos e elaborados do que os marcadores nominais. Este fenômeno é encontrado também nas línguas paleoasiáticas; nas várias línguas do Cáucaso; no grupo centro-sul dravidiano das línguas do sul da Índia; em algumas línguas austronésias e em línguas papua. A marcação pluracional é uma característica areal encontrada no tronco chádico, em uma variedade de línguas nigero-congolesas e línguas nilo-saarianas, incluindo línguas em que a marcação de número não é uma característica flexional proeminente do sintagma nominal.

A pluralidade verbal expressa, nas línguas africanas, ações iterativas ou frequentativas, ou ações envolvendo uma pluralidade de participantes. 
Nas línguas chádicas, por exemplo, o número verbal codifica pluralidade de objetos, pluralidade de sujeitos de verbos intransitivos e pluralidade de eventos, no entanto, não codifica pluralidade de agentes de verbos transitivos (Creissels et al., 2008: 114). Observem-se dados da língua lendo, centro-sudanesa :

$$
\text { ma mí índrí nádha }
$$

1SG SC.AUX cabra RSM.pular:NOMZ

Estou pulando uma cabra ou um grupo de cabras simultaneamente

$$
\text { ma mí índrí núdhà }
$$

Estou pulando várias cabras uma por uma, ou uma cabra várias vezes

(Creissels et al., 2008:114)

No dado em (32), a pluralidade é expressa pela vogal u e pode ter uma leitura distributiva, vários eventos de pular várias cabras, uma de cada vez, ou uma leitura que pluraliza apenas o evento de pular cabra e, nesse caso, é somente uma cabra.

A língua hauçá apresenta exemplos deste fenômeno. O plural verbal a"aikee, em (34), indica que o evento de enviar não é simples, pelo contrário, envolve mais de um tempo e mais de um lugar, ou seja, mais de um evento de enviar, e pode significar "eu os enviei ao mesmo tempo para diferentes lugares", "eu os enviei em tempos diferentes para o mesmo lugar" ou ainda, "eu os enviei em tempos diferentes para lugares diferentes".

naa aikee su

Eu enviar eles

$$
\text { naa a"aikee su }
$$

Eu enviar.PL eles

(Corbett, 2000: 137)

Uma vez que tanto o número verbal quanto o nominal podem aparecer no verbo, pode não ser tão óbvio saber qual tipo está envolvido em cada caso. Em alguns casos, o próprio léxico irá fornecer a informação que o verbo está veiculando, por exemplo, a diferença entre correr e debandar envolve o número de sujeitos participantes, enquanto a diferença entre matar e massacrar envolve o número de objetos. 


\subsubsection{Mamuna e Itamatatiua}

Nas análises sobre a variação na marcação de CV, a suposição geral é que apenas a presença da marca de plural no sintagma nominal já veicularia a ideia de plural (Scherre, 1988, 1994; Guy, 1981; Baxter, 2009; Perini, 2011, entre outros.), tornando a presença da marca de plural no verbo opcional, como em eles trabalha.

Foi possível observar que, para as comunidades de Alcântara, a informação de plural no verbo é ainda importante, ou seja, apesar da redução do ditongo nasal átono final, a informação de morfologia plural ainda é mantida no verbo. Este fato é corroborado inclusive pelo índice percentual de verbos sem qualquer marca de plural, 12\% em Mamuna e 16,5\% em Itamatatiua, valores considerados baixos se comparado a outras comunidades rurais ou quilombolas.

Não é uma tarefa simples identificar se determinada língua ou determinado verbo marcado no plural está veiculando um número verbal ou um número nominal. Corbett (2000: 258) apresenta algumas generalizações para poder reconhecer um número verbal, entre elas estão as seguintes: os verbos tipicamente denotam situações em que a natureza do evento ou estado é substancialmente afetada pelo número de participantes envolvidos; muitos são verbos intransitivos de posição, como sentar, ficar em pé, ou de movimento, tais como ir, andar, correr ou voar, ou ainda transitivos que indicam a causa do movimento, como, por exemplo, levar, pegar, carregar e jogar; caso uma língua mostre número verbal, ele será indicado através de verbos de movimento, posição/localização e não será encontrado nos transitivos a menos que seja encontrado nos intransitivos.

Nos dados das comunidades alcantarenses, encontramos sujeitos singulares com verbos plurais que indicam movimento (35), ou a causa do movimento (36) e (37), o que estaria dentro das generalizações apresentadas por Corbett (2000) para a presença de número verbal.

(35) hoje ELE FICO é dizendo ... que se ELE VÃO matar uma pessoa ....ELE FICO é dizendo - RJ/ITM

(36) elas já fazio louça mas cada qual em sua casa ... hehein ... agora de certos tempo foi que ELA PASSARO fazer ... aqui ... - RJ/ITM

tinha menas gente ... não tinha esse barulho que tem agora ... de radiola ... às vez ELE BOTO ... hehein ... tem às vez tem aí ... às vez é no comércio - ACJ/ITM

Mesmo com a presença da marca de plural apenas no verbo, não é possível dizer que os verbos nos dados (35), (36) e (37) estão se referindo a eventos 
plurais. Em (35) há a indicação de pluralidade por meio de duas locuções verbais. A primeira delas com o verbo de movimento ir (vão matar) e a segunda com a locução fico é dizendo. No primeiro caso, "ir matar uma pessoa", a informação plural relevante parece ser o número de participantes, principalmente pelo fator de ser o evento de matar uma pessoa; já no segundo caso, "ficar dizendo", a informação plural relevante parece incidir sobre o evento, vários eventos de dizer que irá matar alguém.

Em (36), o que é relevante é o fato de as mulheres da comunidade terem mudado o local da fabricação da cerâmica, a locução "passaro fazer" não aponta para diversos eventos de fazer louça, mas sim para o fato, como já apontado, de as mulheres terem deixado de fazer louça em suas casas para fazer no Centro de Produção.

Já em (37), não é tão claro se a informação relevante é o número de participantes ou os vários eventos de ligar a radiola. Contudo, a ideia de múltiplos eventos é reforçada pelos diferentes lugares apontados pela informante, "tem às vez tem aí ... às vez é no comércio", logo, mesmo que esteja se referindo a mais de um participante, a informação proeminente parece ser o evento de "ligar a radiola várias vezes em vários locais".

Nos dados (38), (39) e (40) fica claro que a informação relevante é o número de participantes. Verbos como gostar indicam estado e do tipo melhorar, com sujeito paciente, como é o caso de (40), indica processo. Tanto em (38) quanto em (39) o que está sendo veiculado é a ideia de mais de um participante não gostar de algo e não vários eventos de não gostar, já em (40) a informação de plural pertinente é o número de habitações que melhorou e não diferentes eventos de melhorar, o que fica nítido com a sequência da sentença em que a informante "corrige" as habitação melhorou, retirando a informação de plural do verbo e levando para o sintagma nominal.

(38) porque eu era daquela de ficar observando [...] porque ou você escuta o que eles tem pra falar ... pra te dar experiência ...p pa te dar ... saber o que tu vai dizer ... e assim eu fazia ... e eles ficavo falando falando depois eu entrava ... ELE não GOSTAVO MJLP/MMN

(39) que depois a gente começamo a dizer "ninguém tira foto ... foto é uma coisa que fala por si só ... então a foto fala muito então não tira foto com ninguém" . . ficava olhando pra eles ... eles não gostavo de mim ... nenhuma reunião que tivemos por aqui ELE num GOSTAVO da gente ... porque eu era daquela de ficar observando - MJLP/MMN 
como A HABITAÇÃO também me/MELHORARO né? ... as habitação melhorou porque não tinha ${ }^{5}-\mathrm{CJ} / \mathrm{ITM}$

A sequência de (41) a (43) apresenta verbos irregulares. Nos dados (41) e (42), de maneira semelhante ao (37), não fica claro se a informação de plural pertinente está atrelada ao número de eventos ou à quantidade de participantes. Por exemplo, em (41) parece ser o evento de fazer a cerâmica a informação relevante, já em (42) parece ser o número de participantes, no entanto, não fica evidente nem pelo verbo, tampouco pelo contexto. Já em (43) não há dúvidas de que o número plural incide sobre o número de participantes.

(41) eu acho que foi assim porque ... e surgiu a cerâmica [... ] e eles tavo fugido alguém sabia mexer com cerâmica ... né? ... aí queimava (rocha) no tempo ... não era? ELE FAZIO ... tinha o barraquinho né? ... e alguém sabia - NJ/ITM

(42) tem a roça mas é só porque os mais velho tão tocando pa frente ... né esses mais novo ELE num DIGO assim "bora fazer uma roça" ... eles acho que o sol é muito quente ... que aí aquilo vai sujar a unha - ACJ/ITM

(43) têm outros lugares por aí que eles pode fazer essa ...Centro de Lançamento ... eu esqueci até o lugar ... onde a $M$. falou que tem ... que eles pode ir lá pra lá e fazer ... tem um lugar aí que eles pode fazer ... quer ... quer tirar ... como tiraro o Peru ... e tá lá toda a área ... ELE num USO pra nada ... entendeu — MJLP/MMN

Como apontado no início desta seção, o fato de a língua marcar o número de plural apenas no verbo não significa que ela veicula o número verbal. Os dados em que a informação de plural relevante é o número de eventos pode ser parte da própria semântica do verbo, não obstante, o fato de a marcação ocorrer apenas no verbo é um fenômeno interessante na fala dessas comunidades e, embora nem todas as ocorrências possam ser analisadas como número verbal, apontam para o fato de a informação de plural no verbo ser importante tanto em Mamuna quanto em Itamatatiua.

O mesmo fenômeno poder ser encontrado no português falado no continente africano. Os dados do português de Moçambique revelam que existe essa possibilidade na língua:

(44) UM HOMEM de lá da terra com mulheres daqui COSTUMAM VIVEREM bem.

\footnotetext{
${ }^{5}$ Falando sobre as melhorias na comunidade.
} 


$$
\text { só eram os dois que eram amigos O RESTO ERAM bandidos }
$$

(Gonçalves \& Stroud, 2000: 202)

Em (44) e em (45), o que ocorre é o verbo marcado no plural com um sujeito singular. No primeiro caso, ao invés de concordar com o sujeito singular $\mathrm{um}$ homem, o falante opta por concordar com o nome mais próximo, mulheres, mesmo não sendo o sujeito da oração. No dado (45) ocorre o inverso: ao invés de concordar com o sujeito $o$ resto, que inclusive está adjacente ao verbo, este segue uma espécie de concordância com os verbos anteriores da oração, que foram apresentados no plural, ou, ainda, o resto pode estar sendo interpretado como plural.

O português de Angola não é diferente. Em (46) observa-se a ocorrência do sujeito singular o colega com o verbo no plural irritam. Já no dado em (47) é possível considerar uma leitura coletiva do nome partido, o que justificaria a ocorrência do verbo no plural.

(46) E aí aparece a graça na sala porque muitas das vezes O COLEGA na sala não IRRITAM a professora, irritam é os colegas por estarem neste nível e apresentarem essas dificuldades.

(Inverno, 2011: anexo)

eu quero que se O PARTIDO tiver que ganhar MOSTRAM mais uma vez daquilo que é digno para o povo [...]

(Adriano, 2014: 357)

É significativo lembrar que esta marcação não representa a maior parte dos dados nem nas comunidades alcantarenses nem no português de Angola, tampouco no português de Moçambique, contudo, esse fenômeno merece alguma atenção. Se considerarmos que o número verbal ocorre em todos os troncos das línguas africanas, especialmente no oeste africano, e nas línguas indígenas, é possível afirmar que este traço poderia estar disponível no contato estabelecido na época colonial. E a presença da marcação de plural no verbo com sujeitos singulares nas variedades africanas do português poderia ser um reflexo do contato deste português com as línguas nativas faladas tanto em Angola quanto em Moçambique.

Essas marcações, em que o sujeito permanece no singular mas o verbo apresenta marca de plural, podem ser mais um indício de que a informação de plural no verbo é importante para essas comunidades, independentemente da redução do paradigma pronominal e verbal e, talvez, esse fato poderia ter levado à manutenção de uma morfologia de plural verbal, mesmo reduzida. Devido ao número de dados, especialmente quando comparados aos dados que apresentam sujeitos plurais, não é possível 
afirmar que este seja um resquício de pluralidade verbal, no entanto, o fato de permanecer a leitura plural, seja de eventos seja de participantes, substancia a ideia de que a informação de plural é mantida mesmo com sujeitos singulares.

\subsection{Considerações do Capítulo}

Neste capítulo foi apresentada uma proposta de análise para a marcação intermediária de plural das comunidades alcantarenses que seria resultado do contato com as línguas bantas.

Os falantes das comunidades de Mamuna e Itamatatiua, por meio de um processo fonológico de redução do ditongo nasal pós-tônico final [ $\widetilde{\wp} \tilde{W}] \mathrm{em}$ uma vogal posterior [ $v]$, teriam reanalisado esta última como um morfema de marcação de plural na terceira pessoa. Essa hipótese de reanálise seria reforçada pela ocorrência dessa mesma terminação verbal em contextos nos quais a redução fonológica para [v] não seria prevista, como verbos de segunda conjugação e verbos irregulares.

Essa reinterpretação ficou mais evidente na seção 7.2, com os dados de terceira pessoa de plural no tempo presente e mesmo no pretérito imperfeito. Estes contextos, embora fonologicamente possa neles ocorrer a redução do ditongo átono final para uma vogal posterior, não são comuns em outras comunidades. Contudo, essa terminação se apresenta de forma muito produtiva em verbos conjugados no presente do indicativo e no pretérito imperfeito, porém, as formas no presente apresentam uma singularidade na medida em que se confundem com a forma verbal da primeira pessoa do singular.

Outra evidência que corroboraria a hipótese levantada é a manutenção da base verbal de primeira pessoa do singular em verbos irregulares para acolher esse morfema final, o que pode ser observado nos verbos dizer, fazer, por exemplo. Além da adição deste morfema em verbos que não apresentam alteração na forma verbal plural, como o verbo ter. Estes verbos reforçariam a ideia de reinterpretação na medida em que mantêm uma base favorável à ocorrência deste morfema final, pois, uma vez que ele seria o veiculador da informação de plural na terceira pessoa, todos os verbos deveriam recebê-lo.

No entanto, esse processo de "acolhimento" do morfema de terceira pessoa do plural com verbos no presente e verbos irregulares não gera formas novas, mas "toma emprestado" uma forma verbal que já está disponível no paradigma verbal, a primeira pessoa do singular e, como consequência, a presença do pronome pessoal se faz cada vez mais necessária. 
O fato de este tipo de marcação - com final $\{-0\}-$ ocorrer no português falado em Angola e em Moçambique traria mais evidências para a hipótese de contato apresentada, pois essas variedades de português ainda convivem com as LBs, faladas como línguas nativas pela grande maioria dos falantes, especialmente em Angola.

Foi possível observar, ainda, dentro da perspectiva de contato linguístico, a relevância da ecologia externa para a manutenção ou o desaparecimento de determinadas características. Dadas condições socioeconômicas no Brasil teriam feito com que características fortemente associadas aos falares dos negros africanos e seus descendentes fossem sistematicamente reprimidas tanto por questões sociais quanto por aparelhos formais, como a escolarização. Essa condição, perdurou, inclusive, passado o período posterior à abolição. Ambientes relativamente isolados e distantes desse tipo de repressão teriam tido a possibilidade de manter, e até mesmo expandir, estas características, como é o caso das comunidades alcantarenses. 


\section{Capítulo 8}

\section{Sujeitos coletivos}

\subsection{Considerações teóricas}

Embora a ocorrência de plural verbal com sujeitos coletivos singulares não esteja diretamente relacionada à reanálise do final reduzido como morfema de plural, os dados de Mamuna e Itamatatiua trazem alguns fatos interessantes que diferem do esperado para esse tipo de ocorrência no português brasileiro e serão brevemente explorados neste capítulo.

A variação na marcação verbal é atestada em dados trecentistas do português (Mattos e Silva, 1991). Já nesses dados, fatores como a distância entre o sujeito e o verbo ( (1) e (2)), posposição do sujeito ( (3) e (4)), tipos de sujeito, e fatores semânticos como a interpretação plural (6) ou singular (5) do sujeito eram relevantes para a ocorrência dessa variação.

(1) A MALDADE dos que ficam no mundo MERECERON que aqueles que poderiam profeitar aos outros saian-se do mundo.

(2) Ca a homildade grande do HOMEN BÕÕ, que queria que os seus bõõs feitos sejam ascondudos, esto DEVEN a querer.

(3) Ei razon de me CRECEREN LAGRIMAS E DOOR E CHORO E AMARGURA.

(4) E pelas moradas dalgũũs que TANGIA A NEVOA E O FEDOR.

(5) O SABOR DO LUXURIOSO E O PRAZER HE vermen e fedor.

(6) A MANCEBIA E O DELEITO SON cousas vããs.

(Mattos e Silva, 1991: 95-96)

No que tange aos sujeitos coletivos, dados do português arcaico também revelam uma variação na marcação verbal (cf. dados de (7) a (11)), e a maior 
distância entre o sujeito e o verbo favoreceria a marcação deste último no plural, como é possível observar nos dados (8), (10) e (11):

(7) e daquesta medês dá testemõio todo o POBOO que enton ERA naquela cidade.

(8) Idolo a que O POBOO SANDEU de toda aquela terra FAZIAN honra come a Deus.

(9) GENTE dos lombardos que ERA mui cruevil USOU de toda sua crueza.

(10) Hũa mui gram rua em que morava muita GENTE que primeiramente ORARAN os idolos.

(11) E mandou que toda a outra GENTE QUE SOIA andar con el que FOSSEN com el e LEVASSEN boas vestiduras.

(Mattos e Silva, 1991:96-97)

Essa concordância é encontrada também no latim, conforme exemplo de Tito Lívio (59 a.C. - 19 d.C.) retirado de Bourciez (1956:104) em Silva (2005: 192):

(12) Cetera multitudo frequenti agmine PETUNT Thessaliam ${ }^{1}$.

Mesmo a ocorrência de verbos plurais com sujeitos coletivos singulares sendo um fenômeno evidenciado em dados do português arcaico (Mattos e Silva, 1991; Souza, 2005, entre outros) e registrado também no latim, algumas gramáticas ainda apresentam este tipo de marcação como um desvio de norma, como hipercorreção, ou ainda como uma figura de linguagem permitida apenas em obras literárias (Cunha \& Cintra, 2007), embora admitam que a distância entre o sujeito e o verbo favoreça este tipo de marcação (Bechara, 2007; Cunha \& Cintra, 2007; Castilho, 2010).

Verdade seja que os antigos a usaram muito mais largamente. Hoje se considera deselegante, escandaloso e risível dizer-se abertamente: o povo chegaram. Mas desde que haja algum distanciamento entre o sujeito e o predicado, que evite a deselegância, não faltam exemplos, ainda entre os clássicos modernos que autorizam tal desconcordância. (Adrião, 1945: 252-3)

Na comunidade de Helvécia, na Bahia, esse tipo de marcação está na ordem de $80 \%$, ou seja, dos 30 dados que apresentaram sujeitos coletivos, em 24 o verbo estava no plural.

\footnotetext{
${ }^{1}$ Outra multidão em leva assídua dirigiam-se à Tessália.
} 
Lucchesi et al. (2009: 352) apontam que esse tipo de concordância é um fenômeno semântico, pois nesses casos "o que vem primeiro à mente do falante é a ideia de plural, de mais de um indivíduo, portanto, a indicação do plural, nesses casos, é mais transparente". Nesse sentido, para os autores, o que estaria agindo é a transparência semântica, pressuposto que vem da área de estudo das línguas crioulas, o qual advoga que as regras gramaticais mais rapidamente adquiridas, ou que mais se conservariam, seriam aquelas nas quais a relação entre a forma e o significado é mais direta.

Alguns estudos sobre a variação na concordância verbal não abordam a variação de concordância com sujeitos coletivos singulares (Monguilhott, 2009), ou, se o fazem, abordam en passant a questão. Almeida (2006a) excluiu esse tipo de variação devido à pouca quantidade, também porque a autora não relacionou as ocorrências de sujeito coletivo com verbo no singular. Em todo o corpus da autora, a concordância de verbo plural com sujeito coletivo ocorreu apenas 7 vezes.

Assim como Helvécia, outras comunidades interioranas da Bahia apresentam a concordância semântica com sujeitos coletivos:

$$
\text { O POVO não QUEREM mais licor. }
$$

(Silva, 2005:351)

Silva (2005) observa que os falantes do português popular do interior da Bahia possuem a tendência de aplicar a concordância semântica ${ }^{2}$. Dos 24 dados, 21 , ou seja $70 \%$, apresentam verbo no plural com sujeitos coletivos, no entanto, esse autor não credita essa concordância a algum tipo de continuidade do latim. Em sua visão, todos os casos de variação verbal evidenciados na fala das três comunidades estudadas, a saber, Poções, Morrinhos e Cinzento, são frutos de uma "situação linguageira comum às situações de contato entre línguas".

Em estudo comparativo sobre o PB e o PE, Rubio (2012) detecta este fenômeno, no entanto, observa que os exemplos encontrados, devido ao baixo número, não constituem subsídios para investigação sociolinguística. Não obstante, "apontam para a ocorrência de mais um fenômeno variável tanto na variedade brasileira quanto na variedade europeia, nesse caso, ligado à CV de 3PS, que, como os já apresentados, carece de maior investigação" (pg. 193).

\footnotetext{
${ }^{2}$ Quando a concordância é determinada pelo sentido (Corbett, 2000).
} 
Considerando que os estudos sobre a variação na marcação verbal com nomes coletivos são poucos e em alguns casos essa variação é apenas mencionada (Scherre \& Naro, 1998; Mattos e Silva, 1991; Lucchesi et al., 2009, entre outros), as análises sobre anáforas de nomes coletivos e, ainda, sobre os próprios nomes coletivos podem ajudar a entender esta variação na marcação verbal.

A semântica dos nomes coletivos e plurais já foi amplamente discutida na literatura (ver Link (1983) para a semântica de nomes plurais; Landman (1989) para os nomes de grupos; Lasersohn (1987) para nomes coletivos, entre outros). Os nomes coletivos são semanticamente diferentes dos nomes plurais, embora, em algumas ocasiões, possam referir-se extensionalmente aos mesmos indivíduos (Godoy, 2010, 2013; Neves, 2014, entre outros). Isto fica claro no exemplo clássico a respeito dos comitês, de Landman (1989).

Tem-se, por exemplo, um comitê (A), o Comitê de Recepção a Novos Alunos (CRNA), formado pelos alunos Maria, Pedro e João. Caso o conjunto fosse a soma de seus membros, as sentenças (15) e (16), a seguir, deveriam ser igualmente verdadeiras, o que não é o caso.

(15) Maria, Pedro e João foram ao aeroporto recepcionar os novos alunos.

(16) O Comitê de Recepção aos Novos Alunos foi ao aeroporto recepcionar os novos alunos.

Nas sentenças (15) e (16), caso, por alguma razão, o Pedro não fosse ao aeroporto, a sentença (16) continuaria verdadeira, o que não seria o caso de (15). De outro modo, tomemos como exemplo a formação da seleção olímpica de vôlei do ano de 2016, cujas jogadoras foram Fabiana, Thaísa, Dani Lins, Natália, Fernanda Garay ... Sheilla. Mais uma vez, se o time fosse apenas a soma de seus indivíduos, a interpretação das sentenças (17) e (18) seria a mesma.

(17) Fabiana, Thaísa, Dani Lins, Natália, Fernanda Garay ... Sheilla jogaram muito bem nas Olimpíadas.

(18) A seleção brasileira de vôlei jogou muito bem nas Olimpíadas.

Contudo, caso haja algum problema e a Natália não possa jogar, por exemplo, a denotação de (18) continua a mesma, o que não ocorre com (17). Logo, como já dito anteriormente, o nome coletivo não é apenas a soma de seus indivíduos, embora possa carregar uma noção de pluralidade, o que poderia levar a concordância do verbo, e mesmo de algumas anáforas, para o plural. 
A diferença entre os nomes plurais e coletivos seria então o fato de nomes coletivos referirem-se a grupos com indivíduos, reunidos no mesmo espaço-tempo, os quais, ao serem nomeados por um coletivo, perdem a propriedade individual e passam a ser considerados como uma coletividade indissociável, enquanto os plurais referem-se a um conjunto de indivíduos de maneira dissociável. Dito de outra forma, os nomes coletivos denotam uma entidade indissociável na medida em que os elementos que constituem esse nome são vistos a partir da coletividade que atribuem, não por suas características individuais (Neves, 2014; Guimarães, 2008).

Não seria possível considerar, por exemplo, como uma alcateia um grupo de lobos localizados em diferentes pontos da floresta, nem tampouco seria possível considerar como uma manada um grupo de bois dispersos. É evidente que se pode dizer que a alcateia ou a manada se dispersou, no entanto, os elementos que a compõem precisariam, a priori, estar juntos para serem considerados uma alcateia ou uma manada, para então ela ser dispersada. O inverso já não é possível, ou seja, os elementos separados serem considerados como uma coletividade.

Já o nome plural não tem a função de agrupar, mas sim de indicar que aquela categoria corresponde a mais de um elemento. Tome-se como exemplo a sentença (19):

(19) Joana sempre cuidou muito bem de seus cachorros.

O plural cachorros indica mais de um elemento, e não é entendido necessariamente como cachorros que ocupam o mesmo tempo e espaço - podem ser cachorros que Joana teve ao longo de sua vida em diferentes lugares nos quais ela tenha morado, por exemplo.

Os nomes coletivos teriam sempre a referência de conjunto / grupo / coleção de. A concordância com o sentido dos coletivos é chamada de $a d$ sensum e as anáforas são chamadas de anáforas conceituais e indicam, como já foi exemplificado, uma discordância numérica entre o sujeito morfológico e o verbo ou anáfora. O que parece ser unânime entre os diferentes estudos é que a distância entre o sujeito coletivo e o verbo favorece a marcação do verbo no plural (Mattos e Silva, 1991; Maia, 2011; Bechara, 2007).

Bosque (1999), em Guimarães (2008), aponta que os coletivos são retomados em uma relação anafórica como um conjunto de elementos aos quais não se pode predicar isoladamente, ao contrário dos nomes plurais

Sobre as anáforas conceituais, alguns estudos concordam que não é um caso de "erro", mas que há equivalência semântica entre os termos, e que o fato de os nomes coletivos possuírem uma semântica plural faz com que a remissão com pronome plural seja possível (Olsemann, 2007; Farias et al., 
2012; Russo, 2009; Godoy, 2010). E, ainda, as anáforas chamadas conceituais são fáceis para o falante interpretar e não geram nenhum prejuízo na compreensão nem para os falantes nativos do inglês (Gernsbacher, 1986, 1991), tampouco para os falantes nativos do português brasileiro (Silva, 2004).

As anáforas conceituais podem ocorrer em três situações comunicativas. Na primeira delas os pronomes plurais são utilizados para referir algo que possui mais de uma entidade (múltiplas) ou eventos que ocorrem repetidamente, como, por exemplo:

(20) Eu preciso de UM PRATO. Onde você OS guarda?

(21) Ontem foi MEU ANIVERSÁRIO. Eu costumava me incomodar com ELES, mas ontem não liguei.

(Gernsbacher, 1991: 85: traduzido)

Em (20) pressupõe-se que, nas casas em geral, haja mais de um prato, seria diferente caso o falante quisesse um ferro de passar roupa ou um rodo, por exemplo, dos quais, em geral, há apenas um. Em (21) há um evento que ocorre repetidas vezes, aniversário, logo, é possível retomá-lo com um pronome plural; diferente seria se se tivesse referindo ao aniversário de trinta anos, por exemplo, que só se comemora uma vez.

Na segunda situação comunicativa os pronomes plurais referem-se a nomes genéricos:

(22) Minha mãe sempre me incomoda para usar UM VESTIDO. Ela acha que fico bem NELES, mas eu não acho.

(23) Eu adoro ter UM ANIMAL DE ESTIMAÇÃO. ELES são excelentes companhias.

(Gernsbacher, 1991: 85: traduzido)

Tanto em (22) quanto em (23) há uma referência a nomes genéricos. Em (22) a mãe acha que a filha fica bem em vestidos, no geral, e em (23) diz que os animais de estimação, no geral, são excelentes companhias.

$\mathrm{Na}$ terceira situação comunicativa, que é a que se relaciona diretamente à tese, os pronomes plurais retomam nomes coletivos.

(24) A professora substituta pediu para A CLASSE parar com o mau comportamento. Mas ELES não prestaram atenção nela.

(Gernsbacher, 1991: 85: traduzido)

Além disso, coletivos menos tradicionais também podem ser retomados por pronomes plurais: 
(25) Depois do colégio, minha irmã foi trabalhar na IBM. ELES fizeram uma boa proposta a ela.

(26) Você não imagina o quanto é ruim trabalhar para A PREFEITURA. ELES nunca dizem se seu trabalho será coberto pelo orçamento do mês seguinte.

(Gernsbacher, 1991: 85: traduzido)

Em suma, o que os trabalhos sobre a semântica dos nomes coletivos e sobre as anáforas conceituais revelam é que a possibilidade de retomar nomes coletivos com pronomes plurais ou ainda de o verbo concordar no plural não é marginal na língua, nem possui dificuldade de compreensão para os falantes, ou tampouco é uma característica idiossincrática de alguma comunidade isolada. E, desta feita, não deveria mais ser considerada como um desvio de norma, tal como em algumas gramáticas, ou ainda de hipercorreção, ou pronomes ilegais (nos termos de Gernsbacher, 1991).

\subsection{Sujeitos coletivos nas comunidades alcanta- renses}

Como evidenciei acima, na língua há a possibilidade de verbos plurais concordarem com nomes coletivos e, ainda, estes serem retomados anaforicamente por pronomes plurais.

O fenômeno de concordância verbal plural com sujeito coletivo singular ocorre nos dados das comunidades de Mamuna e Itamatatiua, como podemos observar nos exemplos (27) e (28) a seguir. Dos 88 dados com sujeitos coletivos, 35 (40\%) possuem verbos no plural ou são retomados por pronomes anafóricos plurais.

(27) Belém né ... banhamo no rio ... tem um ri/ né ... o rio é muito bom ...ề ...é bom demais ... O PESSOAL GOSTARO demais — $\mathrm{ACJ} / \mathrm{ITM}$

(28) ...e além do mais eles não querem mostrar o que tá lá estragado ...e os malofícios que eles provocaro com tudo isso ....com isso eles tiraro parte do palmeiral que a comunidade aqui se usufruía que era da comunidade Peru Velho que foi relocada pra uma agrovila ... e ... O PESSOAL ... USAVAM muito essa questão lá do ... da madeira ... nada pode ser retirado de lá - MGS/MMN 
O que é interessante dos dados (27) e (28) é que o sujeito não está distante do verbo, o que seria um fator inibidor deste tipo de concordância (Mattos e Silva, 1991; Maia, 2011; Bechara, 2007).

Bechara (2007) observa ainda que, para esse tipo de concordância, que ele chama de concordância de palavra para sentido, a língua impõe apenas condição de estética, pois "construções como o povo trabalham e a gente vamos soam geralmente desagradável aos ouvidos" - grifo meu. Vale observar, porém, que a fala não segue às regras prescritas pelas gramáticas normativas e que, em termos linguísticos, não há qualquer valoração nas diferentes formas usadas pelos falantes e, dificilmente, as regras linguísticas são regidas por questões estéticas.

Os dados em que o sujeito e o verbo estão distantes e este último concorda no plural são poucos; o que ocorre é o primeiro verbo permanecer no singular e o segundo verbo concordar no plural (29):

(29) O POVO parece que ...PAROU ...PAROU no bom sentido né ...é ... PAROU no bom sentido ... parece que num ... num QUEREM muito assim o negócio do do do ... do serviço e tal — JB/ITM

Quando o sujeito e o verbo estão distantes, o que ocorre algumas vezes é a retomada por um pronome plural (30), embora essa retomada também ocorra sem o sujeito e o verbo estarem distantes (31), (32) e (33):

(30) agora vem OS PESSOAL do São Luís ... faz a festa é vão pa praia ... praia ELES GOSTO muito e todo domingo vem - CMDS/MMN

(31) aí O PESSOAL assim ELES num PARO assim pa pensar 'mbora se ajuntar fazer uma olaria - ACJ/ITM

ESSA TURMA NOVO eu num sei o que ELES QUERE - ACJ/ITM

e aqui ... vei UM PESSOAL de Barreirinha e aí muito trabalhador ... ES SE MATARO por causa de serviço ES SE MATARO ... mas foi uma cena que nós nunca oiamo - CD/MMN

Nomes coletivos que representam órgãos públicos ou governo também apresentam a concordância chamada de ad sensum, nesses casos a distância entre o sujeito e o verbo é um fator relevante. A proximidade entre o sujeito coletivo e o verbo inibiria a concordância ad sensum (cf. (35) e (36)) ao passo que a distância entre o sujeito e o verbo favoreceria a ocorrência deste no plural (34): 
(34) e O GOVERNO tá ajudando demais ... isso aí ... isso aí eu não falo DO GOVERNO ... eu não falo de ... presidente eu não falo de nada ... TÃO fazendo o máximo possível ... TÃO ajudando ... só não estuda quem não quer - RJ/ITM

(35) se ELE se O GOVERNO PRESIDENTE BOTASSE essas coisa pra cá pra gente a gente fica contente ...e (xxx) um posto de saúde e se ele fizer (essa) estrada pra gente a gente fica contente ... com o governo - RJ/ITM

(36) o dante ... chegava O ...PESSOAL DA BASE CHEGAVA (arrastando) nós tava de ... se recolhia e ficava de ... só ... hehein ... com medo tá vendo - $\mathrm{CD} / \mathrm{MMN}$

Outra diferença em relação a este tipo de sujeito é a ocorrência mais frequente de anáfora pronominal plural, exemplificada pelos dados em (37) e (38):

e o GOVERNO FEDERAL manda a gente pra ... ele ... levar na transportadora as peça ... e aí ELES MARCO a viagem pra gente ir - NJ/ITM

A AERONÁUTICA ... tinha alugado aqui a ... uma parte da ... das terra aqui do Centro de Lançamento ... ELES não ALUGARO o Centro de Lançamento ELES QUERIO dar uma parte das terra de Alcântara ...p pra fazer uma base de Lançamento pra Ucrânia MGS/MMN

Não aprofundarei a questão de anáforas plurais retomando sujeitos coletivos neste momento por não ser o objetivo desta tese. É possível encontrar mais detalhes sobre essa questão nos trabalhos já citados de Gernsbacher (1986, 1991), Silva (2004), Olsemann (2007), Mattos (2010), Godoy (2010, 2013), Farias et al. (2012), entre outros.

De fato, nos dados da comunidade, observa-se que, distintamente dos estudos sobre o tema, a concordância plural do verbo com termos coletivos dá-se, na grande maioria, com o sujeito anteposto e adjacente ao verbo, exceto quando o sujeito refere-se a entidades governamentais.

(39) o aluno da professora M. que da universidade ... da UFMA ... então ele disse assim "M. o pro/ o doutor A. ... ele vai sair ... O PESSOAL VÃO sair o advogado vão sair ninguém ainda num falou nada porque eles" ... as pessoas elas tinha medo de falar ... entendeu ..."e ninguém falou nada e...e ... aí a tua conver/ a tua vez é agora" - MJLP/MMN 
(40) porque o governo bota dinheiro ... agora o o prefeito é que num num coisa ...e ele não passou ... esse $S$. ... acho que era $W$. né ... não fez nada ... O POVO SE ENGANARO com ele ... umum $\mathrm{MAJ} / \mathrm{ITM}$

(41) mas de primeiro não tinha assim ... tinha só aquele radinho que a gente escutava [...] hoje em dia todo final de semana tem domingueira tem essas coisa assim ...e aí ... mudou muito né ... O POVO FICARO assim mais agitado ... e de primeiro era tudo mais calmo - ACJ/ITM

(42) ...e lá Baracatatiua eles conseguiram outras pessoas que depois trabalharam várias pessoas lá depois de mim ...e hoje a comunidade está praticamente ... desabitada né ... pouca gente ... O PESSOAL FORO tudo embora - MGS/MMN

Atesta-se, ainda, em Itamatatiua, adicionalmente, a ocorrência de determinante no plural, antes dos nomes coletivos, conforme dados (43) e (44):

(43) tinha uma casinha ali perto da igreja [...] aí as pessoa ensinavo lá também ... aí quando não era isso era aquele MOBRAL ... que fazia OS PESSOAL SE AJUNTAVO eles mesmo fazia (de barro) ... aí também OS PESSOAL ESTUDAVO assim ... não era aquele estudo como tem agora né - ENJ/ITM

(44) eles compra mas ...hehein [...] a louça ficou mais um pouco devagar ... estes dias chegou UNS PESSOAL ... COMPRARO umas peça bacana mesmo também eles ...e .... agora que tem as férias? ... aí eles tão vindo - MAJ/ITM

No português falado em Moçambique também há a ocorrência de verbos no plural com sujeitos coletivos singulares, conforme a sequência de dados de (45) a (50):

(45) Não sei se há uma ORGANIZAÇÃO qualquer deles que POSSAM fazer valer a sua voz...

(Gonçalves \& Stroud, 1998: 100)

(46) A POLÍCIA estava a dez metros do local, mas simplesmente LIMITARAM-SE a dizer

(António, 2011:31)

(47) MUITA GENTE CHUMBAM

(48) Eu vi tanta GENTE ALMOÇAREM lá JANTAREM lá

(49) Esta GENTE APROVEITAM o máximo agora 


$$
\text { Esta GENTE que ESTÁ cá também ESTÃO ricos }
$$$$
\text { A GENTE PASSÁVAMOS refeições }
$$

(Gonçalves \& Stroud, 1998: 126)

Interessante notar que grande parte dos dados - aos quais tive acesso - em que o verbo recebe a marcação de plural com sujeitos coletivos singulares ocorre quando da presença do nome gente, independente se este refere-se à primeira do plural (51) ou ao nome coletivo. Em (50) é possível perceber que o primeiro verbo encontra-se no singular e o segundo recebe a marcação de plural, evidenciando a variação na $\mathrm{CV}$.

No português de Angola também ocorre a marcação de plural no verbo com sujeitos coletivos singulares. Pelos dados aos quais tive acesso, das duas variedades, é possível observar que, de modo distinto ao português de Moçambique, essa marcação é mais ampla no PA, com uma variedade maior de tipos de sujeitos coletivos, não restrita apenas ao nome gente. $\mathrm{O}$ verbo é marcado no plural com sujeitos coletivos singulares que indicam um conjunto de pessoas (52) e (53), semelhante às marcações das comunidades alcantarenses que, em sua grande maioria, marcam o verbo no plural com nomes coletivos singulares do tipo o pessoal, o povo.

$$
\text { é a mudança que eu quero [...] porque O POVO ANGOLANO }
$$
ANDAM a sofrer muito [...]

(Adriano, 2014: 273)

só peço que A POPULAÇÃO SEJAM mais compreensível e ACEITAM daquilo que está acontecer

(Adriano, 2014: 357)

Esse tipo de marcação parece ser mais amplo no português falado em Angola do que no português falado em Moçambique, e também nos dados das comunidades quilombolas de Mamuna e Itamatatiua, como é possível ver nos dados de (54) a (57), em que o verbo é marcado no plural com o sujeito coletivo singular grupo, mesmo quando este sujeito apresenta um determinante singular (cf. (54), (55) e (56)):

(54) depois UM GRUPO de militantes e simpatizantes do Partido liderado pelo seu secretário provincial FORAM ao Comando Provincial da Polícia Nacional onde PROTAGONIZARAM cenas de agressão física a agentes da ordem incluindo a uma oficial superior que viu também sua farda rasgada

tenho provas de UMA FROTA que ESTÁ aqui permanente desde os anos oitenta ESSA FROTA ESTÃO aqui numa média de onze 
embarcações

(Adriano, 2014: 279)

(56) ESTE GRUPO de jovens educadores comunitários PREPARAM-SE para fazer um giro comunitário pelos bairros vão levar mensagens de civismo

(Adriano, 2014:357)

(57) TEM GRUPO de miúdos aqui que DORMEM aqui nesse ...

(Inverno, 2011: anexo)

Em (55) a variação torna-se ainda mais visível, na medida em que o primeiro verbo ocorre no singular (uma frota que está) e o segundo ocorre no plural (essa frota estão).

A presença do quantificador todo ao lado dos sujeitos coletivos singulares não inibe a marcação de plural no verbos, como nos exemplos (58) e (59) a seguir:

eu aconselho A TODA JUVENTUDE que VOTEM

(Adriano, 2014:273)

(59) Por isso é que A MALTA TODA lá da parte destas zonas TINHAM medo que o Savimbe aparecesse porque senão cortava-lhes a cabeça porque ele foi sempre contra

(Chavagne, 2005: anexo: 101)

Para português falado em Cabo Verde, igualmente, é possível observar a ocorrência de verbos no plural com sujeitos coletivos singulares, conforme exemplo em (60):

(60) há GENTE ... deixa fugir um pouco do assunto - há GENTE que USA o facto de existirem variantes para COMBATEREM a oficialização - a escrita - ou o desenvolvimento do crioulo - porque infelizmente há gente em Cabo Verde - e GENTE que CONSTITUI ... que ASSUMEM posições ou atitudes de intelectuais - que ESTÃO contra o crioulo - infelizmente - GENTE que DEVERIAM estar na luta para a afirmação da nação caboverdiana - para a sobrevivência da nação caboverdiana no mundo - acho que estão mais preocupados com a sobrevivência da nação portuguesa - não é?

(Lopes, 2011:483) 
De volta aos dados das comunidades quilombolas, para os sujeitos que não são adjacentes ao verbo, a distância entre eles também não é muito grande, como é possível notar em (61):

(61) tinha uma comunidade na beira da baixa ... né ... chamada Santa Rita ... e lá morava A FAMÍLIA dos Anjos né ...QQUE MORAVAM lá ... e eles ... era só uma família mesmo - MGS/MMN

Sujeitos com relativas parecem não impedir que verbos ocorram no plural com nomes coletivos singulares (cf. (62) a (64)):

(62) ainda tem aquela casinha lá do ... Tele Centro que tem a escolinha agora do ... Tele Centro isso tudo foi através de ... a casinha foi A COMUNIDADE mesmo que ... que conseguiu fazer QUE GANHARO o Tele Centro né mas num tinha [...] a casa aí a gente mesmo ... que se uniu e fizemos — ENJ/ITM

(63) chegou aqui ... quis me comprar [...] ah botou dinheiro que eu nunca peguei na vida ...é ... botou dinheiro que eu nunca peguei na vida ... já olhei ... chegou aqui ó ... “eu vou dar trinta mil pa cada ... cada (fosseiro) desse aí ... pa você acalmar ESSE PESSOAL QUE TÃO brabo e você ... eu vou le dá cento e vinte pra você" $\mathrm{CD} / \mathrm{MMN}$

(64) e então nós ia pra lá fazer o quê? ... pra lá pessas agrovila fazer o quê? certo os que tão lá ainda não ... já morrero muito mas não de fome né porque eles também ... muitos se vale daqui ... da nossa praia [...] nós nunca proibimos ... porque todo mundo tem fome né ... e um é ESSE PESSOAL que SAÍRO ali ...Peru Caramajós ... es pesco mais é aqui ...é na praia aqui - MFF/MMN

Por fim, esse tipo de concordância também é possível com termos genéricos:

$$
\begin{aligned}
& \text {... A MULHER parece que ... se ORGANIZO mais as coisa eu - } \\
& \text { NJ/ITM }
\end{aligned}
$$

Apesar de os estudos sobre o tema apontarem a possibilidade de concordância de verbos no plural com nomes coletivos singulares, os dados de Mamuna e Itamatatiua diferem dos demais estudos no tocante aos fatores que favorecem esse tipo de concordância.

O que parece ser uma unanimidade entre os estudos, que a distância entre o sujeito e o verbo favorece a marcação deste no plural ao passo que a proximidade inibe, não se mostrou verdadeiro no caso dessas comunidades quilombolas nem para as variedades africanas do português. Pelo contrário, 
na grande maioria dos dados que apresentaram a marcação verbal plural, o sujeito estava adjacente ao verbo, o que mostraria uma singularidade deste tipo de marcação nas comunidades ora estudadas e, ainda, que a restrição da língua mencionada por Bechara (2007) não se aplica, pelo menos aos dados dessas comunidades.

\subsection{Considerações do Capítulo}

Neste capítulo foi explorada brevemente a ocorrência de verbos plurais com sujeitos coletivos singulares. Embora esta marcação não represente a maioria das marcações do plural nem nas comunidades alcantarenses nem no português de Angola, tampouco no português de Moçambique, sua ocorrência é significativa, pois, ao considerarmos que o número verbal ocorre em todos os troncos das línguas africanas, especialmente no oeste desse continente, é possível afirmar que, assim como a marcação de plural no verbo com sujeitos singulares evidenciou, a morfologia verbal de plural é importante nessas comunidades.

Embora a ocorrência dessa marcação de plural com nomes coletivos não se relacione diretamente com a hipótese de reinterpretação do final verbal reduzido como morfema marcador de terceira pessoa do plural, apresenta uma característica que, teoricamente, não seria prevista para o português. É possível observar que esses sujeitos coletivos estão sendo interpretados como plurais e a distância entre eles e o verbo não seria mais inibidora da marcação de plural no verbo.

De acordo com diferentes estudiosos do tema, verbos plurais com nomes coletivos singulares só poderiam ocorrer caso o sujeito estivesse distante do verbo; mas não é o que foi observado nos dados das comunidades alcantarenses apresentados na subseção 8.2, nem nos dados do PA e do PM. 


\section{Capítulo 9}

\section{Considerações Finais}

Na presente tese explorei a marcação de plural de terceira pessoa nas comunidades de Mamuna e Itamatatiua, em Alcântara (MA). Diferentemente de estudos que abordam o mesmo tema, nas comunidades alcantarenses, há, ao lado da marcação padrão e não padrão de plural, um terceiro tipo, ao qual denominei de marcação intermediária de plural.

Esta marcação intermediária, além de representar o maior número de ocorrências, aparece em contextos distintos dos evidenciados nas comunidades em que há a redução do ditongo nasal pós-tônico final, como verbos conjugados no presente do indicativo, no pretérito imperfeito, verbos de $2^{a}$ conjugação e verbos irregulares.

Esses contextos distintos, assim como a quantidade de ocorrências, mostraram a necessidade de olhar para tal redução de modo mais detido, pois pareciam ser não apenas um fenômeno de redução fonológica. Ao que parece, esse morfema resultante da redução do ditongo nasal átono final estaria sendo entendido pelos falantes das comunidades alcantarenses como morfema marcador de terceira pessoa do plural.

Diante disso, levantei a hipótese de que essa redução poderia ter sido influência do contato com as línguas africanas durante o período colonial, uma vez que essa forma reduzida era sempre apontada como característica da fala dos pretos.

Ao olhar para as línguas bantas, percebe-se uma tendência a evitar encontros vocálicos. Alguns autores chegam a postular, inclusive, que não há ditongos nas LBs. Tal tendência a evitar encontros de vogais faz com que essas línguas lancem mão de diversos processos fonológicos, como a elisão e a assimilação, por exemplo.

Esses processos fonológicos, vistos nas LBs como uma resposta a sua tendência em evitar encontro de vogais, estariam presentes no banco de traços em competição formado pelas línguas em contato no período colo- 
nial, e o contexto átono final dos verbos de terceira pessoa do plural do português brasileiro estaria mais propenso à aplicação de tais processos.

O fato de esse tipo de marcação reduzida ocorrer de forma mais ampla nas comunidades de Mamuna e Itamatatiua seria devido, então, à ecologia externa de formação dos quilombos.

$\mathrm{O}$ abandono das terras pelos senhores e o relativo isolamento daquelas comunidades teria feito com que esses traços da fala dos pretos não sofressem tanta repressão pelos meios sociais. $\mathrm{O}$ fato teria possibilitado então não só a ocorrência dessa marcação verbal reduzida de maneira mais ampla, mas também a sua posterior reinterpretação como morfema de terceira pessoa do plural e sua consequente ampliação para os demais contextos de 3PP.

A marcação de plural com sujeitos singulares, assim como com sujeitos coletivos, apontou para a importância da morfologia verbal de plural nessas comunidades. Isso pode ser devido ao contato com línguas que possuem pluralidade verbal, tanto bantas quanto indígenas.

Como Mufwene $(2001,2008)$ observa, a reestruturação de línguas, resultante de variedades em contato, não pode ser explicada somente por fatores externos ou internos. A confluência das duas ecologias é que é capaz de explicar o porquê de, mesmo diante dos mesmos traços, as comunidades seguirem caminhos distintos.

O que a análise desses dados revela é que o estudo sobre os traços linguísticos que contribuíram para o contato entre as diferentes línguas que formaram o PB não é sempre óbvio. Muitas vezes, não há apenas um elemento morfológico ou sintático que afeta as características advindas desse contato, mas o que pode ocorrer é a interferência de fatores fonéticos, fonológicos, morfológicos, sintáticos e até semânticos para a constituição de uma única mudança advinda deste contato entre diferentes línguas. Isso leva o linguista a analisar diferentes fenômenos para que os "sinais" possam ser interpretados de maneira correta para o entendimento de uma dada peculiaridade da língua estudada.

Adicionalmente, o contexto histórico de formação e a interação entre os falantes revelam-se, igualmente, essenciais para o entendimento de características distintas existentes em comunidades que tiveram os mesmos traços linguísticos em contato.

Por fim, a tarefa de estudar esse contato não é fácil. Ainda mais partindo de dados atuais para postular interações anteriores, às quais não temos acesso sequer por documentos, uma vez que estes, além de retratarem o contexto colonial e imperial a partir de uma visão da elite lusófona, não procuravam registrar como se dava a vida ou a interação da população que compunha as camadas mais desfavorecidas da sociedade, especialmente 
relativas à população africana e negra escravizada. Em primeiro lugar, embora possamos traçar a origem das línguas africanas trazidas para cá, não temos como precisar todas as línguas que desembarcaram aqui e nem qual a quantidade de falantes dessas línguas para se ter uma noção dos inputs que colaboraram para este contato.

Em segundo lugar, a dificuldade reside em realizar uma reconstituição histórica dessa interação e, como já apontado, não temos registros detalhados a respeito da camada da população que contribuiu maciçamente para a formação do $\mathrm{PB}$, os africanos escravizados e seus descendentes. Os relatos existentes são feitos sempre nas mesmas bases, retratando de maneira geral como eram a rotina de trabalho, a alimentação, a relação entre senhores e escravos, os castigos físicos, as tentativas de fuga, entre outras informações. Não há registros de como se dava a interação entre os escravizados na senzala, por exemplo, ou como era a interação deles com outras pessoas das camadas pobres; os registros apontam apenas que este tipo de interação de fato existiu, mas não como ela se deu.

Os documentos sobre a interação dos aquilombados também são inexistentes, ou praticamente inexistentes. As informações são as reproduzidas pelas pessoas que queriam destruir esses quilombos, com uma visão estratégica e muitas vezes militarista. Resta-nos, então, apenas supor como se dava essa interação, dado que é sabido que conviviam escravizados fugidos, ex-escravizados e pessoas livres nesses ambientes.

Precisar, ainda, quais traços selecionados pelos falantes nessas interações a partir de uma língua já "modificada", também requer uma análise cuidadosa, uma vez que partimos do sentido inverso, analisar as características existentes no PB e tentar traçar a origem dessas características nas línguas que supostamente participaram desse contato. No final das contas, as conclusões às quais se chega sempre residirão no campo das hipóteses.

Essas dificuldades, no entanto, não tornam a análise dos dados menos confiável, ou significam que não é preciso que seja realizada de maneira acurada; muito pelo contrário, tentar traçar as origens do PB é uma tarefa que requer muita diligência e os trabalhos realizados até o momento mostram que este é um caminho próspero de análise. A presente tese tentou contribuir para o debate. Espero ter alcançado esse intento. 


\section{Referências Bibliográficas}

Adriano, P. S. (2014). Tratamento morfossintático de expressões e estruturas frásicas do português em Angola: divergências em relação à norma europeia. Tese de doutorado, Universidade de Évora.

Adrião, P. (1945). Tradições clássicas da língua portuguesa. Porto Alegre. Edição de 2010.

Alexiadou, A., L. Haegeman, \& M. Stavrou (2007). Noun Phrase in the Generative Pespective. Berlim / New York: Mouton de Gruyter.

Alkmin, T. \& M. Petter (2008). África no Brasil: a formação da lingua portuguesa, Capítulo Palavras da África no Brasil de ontem e de hoje, pp. 145 - 177. São Paulo: Editora Contexto.

Almeida, A. P. d. (2006a). A concordância verbal na comunidade de são miguel dos pretos, restinga seca, rs. Dissertação de mestrado, Universidade Federal do Rio Grande do Sul.

Almeida, A. W. B. d. (2006b). Os quilombolas e a Base de lançamento de foguetes de Alcântara: laudo antropológico, Volume 1. Brasília: MMA.

Almeida, A. W. B. d. (2006c). Os quilombolas e a base de lançamento de foguetes de Alcântara: laudo antropológico, Volume 2. Brasília: MMA.

Almeida, M. A. L. d. (2014). História Social da Língua Nacional 2: Diáspora Africana, Capítulo Tráfico de africanos para o Brasil, pp. 353 - 361. Rio de Janeiro: Editora NAU.

Amaral, A. (1920). O dialeto caipira (1982 ed.). São Paulo: Hucitec/Secretaria da cultura, ciência e tecnologia.

Antonino, V. (2007). A concordância nominal em predicativos do sujeito e em estruturas passivas no português popular do interior do estado da bahia. Dissertação de mestrado, Institudo de Letras da Universidade Federal da Bahia. 
António, T. (2011). Estratégias de ensino da concordância verbal em número à população universitária moçambicana. Dissertação de mestrado, Faculdade de Letras e Ciências Sociais da Unviersidade Eduardo Mondlane.

Araujo, S. S. d. F. (2014). A concordância verbal no português falado em Feira de Santana - BA: sociolinguística e sócio-história do português brasileiro. Tese de doutorado, Instituto de Letras da Universidade Federal da Bahia.

Assunção, M. R. (1996). Liberdade por um fio: história dos quilombos no Brasil, Capítulo Quilombos maranhenses, pp. 433-466. São Paulo: Companhia das Letras.

Assunção, M. R. (2010). A memória do tempo de cativeiro no maranhão. Tempo. Revista do Departamento de História da UFF 14, 67-110.

Baptista, M. (2002). The syntax of Cape Verdean Creole - the Sotavento Varieties, Volume 54. Amsterdam / Philadelphia: John Benjamins.

Barbosa, M. A. (1996). Língua e Discurso: contribuição aos estudos semânticosintáticos (4 ed.). São Paulo: Editora Plêiade.

Battisti, E. (1997). A nasalisação no português brasileiro e a redução dos ditongos nasais átonos: uma abordagem baseada em restrições. Tese de doutorado, Pontifícia Universidade Católica do Rio Grande do Sul.

Battisti, E. (2002). Fonologia e variação - recortes do português brasileiro, Capítulo A redução dos ditongos nasais átonos, pp. 183-202. Porto Alegre: EDIPUCRS.

Battisti, E. \& M. J. B. Vieira (2001). Introdução a estudos de fonologia do português brasileiro, Capítulo O sistema vocálico do português, pp. 159194. Porto Alegre: EDIPUCRS.

Bavo, N. (2015). Caderno de Pesquisa $n^{0}$ 1: Didáctica do Português L2, Capítulo Concordância verbal, pp. 47-58. Maputo: Cátedra de Português Língua Segunda e Estrangeira/Universidade Eduardo Mondlane.

Baxter, A. (2009). O Português Afro-Brasileiro, Capítulo A concordância de número, pp. 269-293. Salvador: EDUFBA.

Baxter, A. N. (1992). Actas do Colóquio sobre Crioulos de base lexical portuguesa, Capítulo A contribuição das comunidades afro-brasileiras isoladas para o debate sobre a crioulizaçao prévia: um exemplo do estado da Bahia, pp. 7-35. Lisboa: Colibri. 
Bazenga, A. M. (2015). A concordância verbal em variedades do português: a interface fonética-morfossintaxe, Capítulo A concordância de terceira pessoa plural: a variedade insular do PE (Funchal), pp. 76-103. Rio de Janeiro: Vermelho Marinho.

Bechara, E. (2007). Moderna Gramática Portuguesa (38 ed.). Rio de Janeiro: Editora Lucerna.

Bento, C. T. J. S. F. (2010). Contributos para uma caracterização linguística do luandense. Dissertação de mestrado, Universidade de Aveiro.

Bisol, L. (1989). O ditongo na perspectiva da fonologia atual. D.E.L.T.A..

Bleek, W. H. I. (1862). A Comparative Grammar of South African Languages Part 1: Phonology. London: Trübner \& Co.

Bonvini, E. (2002). História do saber lexical e constituição do léxico brasileiro, Capítulo Palavras de origem africana no português do Brasil: do empréstimo à integração, pp. 147 - 162. São Paulo: Humanitas/FFLCH/USP.

Bonvini, E. (2008a). África no Brasil: a formação da língua portuguesa, Capítulo Línguas africanas e o português falado no Brasil, pp. 15-62. São Paulo: Editora Contexto.

Bonvini, E. (2008b). África no Brasil: a formação da língua portuguesa, Capítulo Os vocábulos de origem africana na constituição do português falado no Brasil, pp. 101 - 144. São Paulo: Editora Contexto.

Bopp da Silva, T. (2005). A redução da nasalidade em ditongos de sílaba átona em final de vocábulo entre falantes bilíngues e monolíngues do rio grande do sul. Dissertação de mestrado, Universidade Federal do Rio Grande do Sul.

Bosque, I. (1999). Gramática descriptiva de la lengua española: Sintaxis básica de las clases de palabras, Capítulo El nombre común, pp. 3-73. Barcelona: Real Academia Española.

Bourciez, E. (1956). Éléments de linguistique romane. Paris: Klincksieck.

Braga, Y. M. R. d. O. (2011). Território étnico: conflitos territoriais em alcântara, maranhão. Dissertação de mestrado, Universidade do Vale do Paraíba.

Brandão, S. F. (2011). Concordância nominal em duas variedades do português: convergências e divergências. Veredas 15, 164-178. 
Brandão, S. F. (2013). Patterns of agreement within the noun phrase. Journal of Portuguese Linguistics 12, 51-100.

Brandão, S. F. \& S. R. Vieira (2012). Concordância nominal e verbal: contribuições para o debate sobre o estatuto da variação em três variedades urbanas do português. Alfa 3, 1035-1064.

Buthers, C. M. \& F. B. Duarte (2012). Português brasileiro: uma língua de sujeito nulo ou de sujeito obrigatório? Diacrítica 26, 63-87.

Cabredo-Hofherr, P. \& B. Laca (2012). Verbal Plurality and Distributivity. Berlin: Linguistische Arbeiten Series.

Carvalho, N. F. d. (1989). A natureza do gênero em português. Alfa 1, 55-88.

Castilho, A. T. d. (2010). Gramática do Português Brasileiro. São Paulo: Editora Contexto.

Castro, A. \& F. Pratas (2006). Studies on agreement, Capítulo Capeverdean DP-internal number agreement: additional arguments for a distributed morphology approach, pp. 11-24. Amsterdam: John Benjamins.

Castro, Y. P. d. (2001). Falares Africanos na Bahia - um vocabulário afro-brasileiro. Rio de Janeiro: Topbooks.

Cestari, G. A. d. V., L. B. Caracas, \& D. M. Santos (2014). Artesanato tradicional, design e sustentabilidade: com a palavra quem produz cerâmica em Itamatatiua. Strategic Design Research Journal 2, 84-94.

Chavagne, J.-P. (2005). La langue portugaise d'Angola. Etudes des écarts par rapport à la norme européenne du portugais. Tese de doutorado, Université de Lyon 2.

Corbett, G. G. (1991). Gender. New York: Cambridge University Press.

Corbett, G. G. (2000). Number. Cambridge: Cambridge University Press.

Costa, E. V. d. (1997). Da senzala à colônia (2010 ed.). São Paulo: Fundação Editora da UNESP.

Creissels, D., G. J. Dimmendaal, Z. Frajzyngier, \& C. König (2008). A Linguistic Geography of Africa, Capítulo Africa as a morphosyntactic area, pp. 86 - 150. Nova York: Cambridge University Press. 
Cunha, A. S. d. A. (2003). A atuação do 'Parâmetro do Sujeito Nulo' na variedade popular do português falado nos quilombos do Maranhão. Tese de doutorado, Universidade de São Paulo.

Cunha, C. \& L. F. L. Cintra (2007). Nova Gramática do Português Brasileiro (4 ed.). Rio de Janeiro: Lexicon Editora Digital.

Cyrino, S. \& M. E. Duarte (2000). Brazilian Portuguese and the Null Subject, Capítulo Visible subjects and invisible clitics in Brazilian Portuguese, pp. 55-73. Frankfurt: Iberoamericana -Vervuert.

Dias, P. (1697). Arte da língua de Angola. Lisboa: Oficina de Miguel Deslandes, Impressor de Sua Majestade.

Duarte, M. E. (1993). Português Brasileiro: uma viagem diacrônica, Capítulo Do pronome nulo ao pronome pleno: a trajetória do sujeito no português do Brasil, pp. 107-128. Campinas: Editora UNICAMP.

Duarte, M. E. (2000). Brazilian Portuguese and the Null Subject, Capítulo The loss of the Avoid Pronoun Principle in Brazilian Portuguese, pp. 17-36. Frankfurt: Iberoamericana -Vervuert.

Duarte, M. E. (2003). Mudança Linguística em Tempo Real, Capítulo A evolução na representação do sujeito pronominal em dois tempos, pp. 115-128. Rio de Janeiro: Contra Capa.

Dzeco, J. J. (2011). Estratégias didácticas adoptadas pelos professores para o ensino da concordância nominal em número nas escolas primárias moçambicanas localizadas nas zonas rurais. Dissertação de mestrado, Faculdade de Letras e Ciências Socias da Universidade Eduardo Mondlane.

Elia, S. (1987). Sociolinguística. Rio de Janeiro: Padrão.

Faria, N. V. M. d. (2008). A concordância verbal no português de belo horizonte. Dissertação de mestrado, Pontifícia Universidade Católica/MG.

Faria, R. H. M. d. (2012). Mundos do trabalho no Maranhão oitocentista: os descaminhos da liberdade. São Luís: EDUFMA.

Farias, S. C. d., M. M. Leitão, \& J. Ferrari-Neto (2012). Gênero e número no processamento da anáfora conceitual com nomes coletivos em português brasileiro. ReVEL 1(6), 82-109. 
Fernandes, F. (1963). Organização social dos tupinambás. São Paulo: Difusão Europeia do Livro.

Figueiredo, C. \& M. S. D. d. Oliveira (2013). Português do Libolo, Angola, e o português afro-indígena de Jurussaca, Brasil: cotejando os sistemas de pronominalização. PAPIA 23, 105-185.

Figueiredo, C. F. G. (2008). A concordância variável no sintagma nominal plural do português reestruturado de Almoxarife (São Tomé). Papia: Revista de Crioulos de Base Ibérica 18, 23-43.

Gameiro, M. B. (2005). A concordância verbal na língua falada da região central do estado de são paulo. Dissertação de mestrado, Faculdade de Ciências e Letras, Universidade Estadual Paulista.

Gernsbacher, M. A. (1986). Comprehension of conceitual anaphora in discourse. In Proceedings of the Cognitive Science Society.

Gernsbacher, M. A. (1991). Comprehending conceptual anaphors. Language and Cognitive Processes 2, 81-105.

Gilman, C. (1986). African areal characteristics: sprachbund, not substrate? Journal of Pidgin and Creole Languages 1, 33-50.

Gleason Jr, H. A. (1978). Introdução à Linguística Descritiva. Lisboa: Fund. Calouste Gulbenkian.

Godoy, M. C. (2010). Resolvendo a anáfora conceitual: um olhar para além da relação antecedente / anafórico. Dissertação de mestrado, Instituto de Estudos da Linguagem da Universidade Estadual de Campinas.

Godoy, M. C. (2013). A influência da predicação nas leituras plurais e singulares dos termos coletivos: um estudo empírico. Revista (Con) Textos Linguísticos 7, 105-125.

Gomes, C. A., C. Mesquita, \& T. d. S. Fagundes (2013). Revisitando a variação entre ditongos nasais finais átonos e vogais orais na comunidade de fala do Rio de Janeiro. Revista Diacrítica 27, 153-173.

Gomes, C. C. \& B. Okoudowa (2015). Introdução à Linguística Africana, Capítulo Morfologia, pp. 127-157. São Paulo: Editora Contexto.

Gomes, F. d. S. (1997). A Hidra e os Pântanos: quilombos e mocambos no Brasil (sécs. XVII - XIX). Tese de doutorado, Universidade Estadual de Campinas. 
Gomes, F. d. S. (2005). A hidra e os pântanos: mocambos, quilombos e comunidades de fugitivos no Brasil. São Paulo: Editora UNESP.

Gonçalves, P. (2001). Panorama geral do português de Moçambique. Revue Belge de Philologie et d'Histoire 79, 977-990.

Gonçalves, P. (2015). Aspectos morfossintáticos da gramática do português de moçambique: a concordância nominal e verbal. Cuadernos de la ALFAL 1(7), 9-16.

Gonçalves, P. \& F. Chimbutane (2004). O papel das línguas bantu na génese do português de Moçambique: o comportamento sintáctico de constituintes locativos direccionais. PAPIA 14, 1-29.

Gonçalves, P. \& C. Stroud (Eds.) (1998). Panorama do português oral de Maputo: Estruturas Gramaticais do Português: problemas e aplicações, Volume III. Maputo: Imprensa Universitária.

Gonçalves, P. \& C. Stroud (Eds.) (2000). Panorama do português oral de Maputo: Vocabulário Básico do Português (espaço, tempo e quantidade): contextos e prática pedagógica, Volume IV. Maputo: Imprensa Universitária.

Gonçalves, S. C. L. \& C. F. Rubio (2010). Confrontos e contrastes entre duas variedades lusófonas no emprego da concordância verbal. Língua portuguesa: ultrapassar fronteiras, juntar culturas 1, 158-179.

Gonçalves, V. d. F. (2007). A ausência de concordância verbal no vale do rio doce-mg. Dissertação de mestrado, Faculdade de Letras, UFMG.

Gowlett, D. (2003). The Bantu Languages, Capítulo Zone S, pp. 609-630. Nova York: Routledge.

Graciosa, D. (1991). Concordância verbal na fala culta carioca. Dissertação de mestrado, Universidade Federal do Rio de Janeiro.

Guimarães, A. C. C. (2008). Caracterização dos nomes coletivos em português - aspectos estruturais. Dissertação de mestrado, Universidade Federal de Uberlândia.

Guthrie, M. (1948). The Classification of the Bantu Languages. Londres, Nova York e Toronto: International Africa Institute by the Oxford University Press. 
Guy, G. R. (1981, a). Linguistic variation in Brazilian Portuguese: aspects of phonology, sintax and language history. Tese de doutorado, University of Pennsylvania.

Harris, J. W. (1991). The exponence of gender in spanish. Linguistic Inquiry 1(22), 27-62.

Heine, B. (1982). Apprehension: das sprachliche Erfassen von Gegenständen, Capítulo African noun class systems, pp. 189-216. Tübingen: Gunter Narr Verlag.

Heine, B. \& Z. Leyew (2008). A Linguistic Geography of Africa, Capítulo Is Africa a linguistic area?, pp. 15-35. New York: Cambridge University Press.

Holm, J. (1992). Vernacular Brazilian Portuguese: a semi-creole. In E. D'Andrade \& A. Kihm (Eds.), Actas do Colóquio sobre crioulos de base lexical portuguesa, pp. 37-66. Lisboa: Colibri.

Holm, J. (2004). Languages in Contact: the partial restructuring of vernaculars. Cambridge: Cambridge University Press.

Holm, J. (2011). Os contatos linguísticos no Brasil, Capítulo O português do Brasil e o português europeu, pp. 157-172. Belo Horizonte: Editora UFMG.

Hyman, L. M. (2003). The Bantu Languages, Capítulo Segmental Phonology, pp. 42-59. Nova York: Routledge.

Inverno, L. (2011). Contact-induced restructuring or Portuguese morphosyntax in interior Angola: Evidence from Dundo (Lunda Norte). Tese de doutorado, Universidade de Coimbra.

Inverno, L. C. C. (2005). Angolas's transition to vernacular portuguese. Dissertação de mestrado, Faculdade de Letras da Universidade de Coimbra.

Katamba, F. (2003). The Bantu Languages, Capítulo Bantu nominal morphology, pp. 103-120. London: Taylor \& Francis Routledge.

Labov, W. (2003). Sociolinguistics: the essential readings, Capítulo Some sociolinguistic principles, pp. 234-250. Malden: Blackwell Publishing.

Lago, A. B. P. d. (1822). Estatística histórico-geográfica da Província do Maranhão. Lisboa: Typ. da Real Academia das Ciências. 
Landman, F. (1989). Groups i; groups ii. Linguistics and Philosophy 12(5), $559-605 ; 723-744$.

Lasersohn, P. (1987). Papers from the 23rd Regional Meetings of the Chicago Linguistic Society, Capítulo Collective Nouns and Distributive Determiners, pp. 214-229. Chicago: Chicago Linguistic Society.

Lasersohn, P. (1995). Plurality, Conjunction and Events. Dordrecht / Boston / London: Kluwer Academic Publishers.

Lemle, M. \& A. J. Naro (1977). Competências básicas do português. Technical report, Relatório final de pesquisa apresentado às instituições patrocinadoras, Fundação MORBRAL e Fundação Ford.

Lima, C. d. (1981). História do Maranhão. São Luís: Senado Federal.

Lima, F. B. d. (2014). Comunidade quilombola Caiana dos Crioulos: um estudo sociovariacionista. Tese de doutorado, Universidade Federal da Paraíba.

Link, G. (1983). Meaning, Use and Interpretation of Language., Capítulo The Logical Analysis of Plurals and Mass Terms: A Lattice-theoretical Approach, pp. 127-146. Berlin: de Gruyter.

Lins, A. B. (2009). Do português arcaico ao português brasileiro: outras histórias, Capítulo Três hipóteses e alguns caminhos para melhor compreender o processo constitutivo do português brasileiro, pp. 272 - 296. Salvador: EDUFBA.

Lopes, A. M. V.-C. d. M. (2011). As linguas de Cabo Verde: uma radiografia sociolinguística. Tese de doutorado, Universidade de Lisboa.

Lucchesi, D. (2000). A variação na concordância de gênero em uma comunidade de fala afro-brasileira: novos elementos sobre a formação do português popular do Brasil. Tese de doutorado, Universidade Federal do Rio de Janeiro.

Lucchesi, D. (2006). Parâmetros sociolinguísticos do português brasileiro. Revista da Abralin 5(1 e 2), 83-112.

Lucchesi, D. (2009a). O português afro-brasileiro, Capítulo A concordância de gênero, pp. 295-318. Salvador: EDUFBA.

Lucchesi, D. (2009b). O português afro-brasileiro, Capítulo História do contato entre línguas no Brasil, pp. 41-73. Salvador: EDUFBA. 
Lucchesi, D. (2009c). O português afro-brasileiro, Capítulo A realização do sujeito pronominal, pp. 167 - 183. Salvador: EDUFBA.

Lucchesi, D. (2012). A diferenciação da língua portuguesa no Brasil e o contato entre línguas. Estudo linguístico galega 4, 45-65.

Lucchesi, D., A. Baxter, \& J. A. A. d. Silva (2009). O Português afro-brasileiro, Capítulo A concordância verbal, pp. 331 - 372. Salvador: EDUFBA.

Luna, F. V. \& H. S. Klein (2010). Escravismo no Brasil. São Paulo: Edusp / Imprensa Oficial do Estado de São Paulo.

Magalhães, T. M. V. (2004). A valoração de traços de concordância dentro do DP. DELTA 20, 149-170.

Maia, J. P. F. (2011). Variação na concordância verbal com nomes coletivos em fortaleza - ce. Dissertação de mestrado, Universidade Federal do Ceará, Centro de Humanidades.

Marroquim, M. (1934). A língua do nordeste (Alagoas e Pernambuco) (2008 ed.). Maceió: UFAL.

Mateus, M. H. M. \& E. d'Andrade (2000). The phonology of Portuguese. Oxford: Oxford University Press.

Mattos, S. E. R. (2010). Pluralização com sujeito de tipo coletivo singular. Revista Linguística 6, 73-85.

Mattos e Silva, R. V. (1991). Caminhos de mudanças sintático-semânticas no português arcaico. Cadernos de Estudos Linguísticos (UNICAMP) 1(1), 59-74.

Mattos e Silva, R. V. (2004). Ensaios para uma sócio-história do português brasileiro. São Paulo: Parábola Editorial.

Mattoso, K. d. Q. (1979). Etre esclave au Brésil: XVI - XIX siècle. Paris: Hachette.

Mattoso Camara Jr, J. (1973). Princípios de Linguística Geral (4 ed.), Volume 5. Rio de Janeiro: Livraria Acadêmica.

Mattoso Camara Jr., J. (2004). Estrutura da Lingua Portuguesa (363 ed.). Petrópolis: Editora Vozes.

Meeussen, A. E. (1975). Possible linguistic africanisms ( fifth hans wolff memorial lecture). Language Sciences 35, 1-39. 
Mello, H. (2011). Os contatos linguísticos no Brasil, Capítulo Formação do português brasileiro sob a perspectiva da linguística de contato, pp. 173185. Belo Horizonte: Editora UFMG.

Mello, H., C. V. Altenhofen, \& T. Raso (Eds.) (2011). Os contatos linguísticos no Brasil. Belo Horizonte: Editora UFMG.

Mendonça, R. (1933). A influência africana no português do Brasil (2012 ed.). Brasília: Fundação Alexandre de Gusmão.

Miller, D. G. (2002). Nonfinite structures in theory and change. Oxford: Oxford University Press.

Miranda, W. (2013). O sintagma nominal do caboverdiano: uma investigação semântica. Dissertação de mestrado, Departamento de Linguística. Faculdade de Filosofia, Letras e Ciências Humanas da Universidade de São Paulo.

Modesto, M. (2010). Brazilian Portuguese says about control: Remarks on Boeckx \& Hornstein. Syntax 13, 78-96.

Modesto, M. (2011). Estudos da linguagem, casamento entre temas e perspectivas, Capítulo Infinitivos flexionados em português brasileiro e sua relevância para a teoria do controle, pp. 63-87. João Pessoa: Ideia.

Modesto, M. (2016). The morphosyntax of Portuguese and Spanish in Latin America, Capítulo Inflected infinitives and restructuring in Brazilian Portuguese, pp. 157-176. New York, NY: Oxford University Press.

Monguilhott, I. d. O. e. S. (2009). Estudo sincrônico e diacrônico da concordância verbal de terceira pessoa do plural no PB e no PE. Tese de doutorado, Universidade Federal de Santa Catarina.

Monguilhott, I. d. O. e. S. \& I. L. Coelho (2002). Variação e mudança no português falado na região Sul, Capítulo Um estudo da concordância verbal de terceira pessoa em Florianópolis, pp. 189-215. Pelotas: Educat.

Monte, A. (2007). Concordância verbal e variação: uma fotografia sociolinguística da cidade de são carlos. Dissertação de mestrado, Faculdade de Ciências e Letras, Universidade Estadual Paulista.

Monte, A. (2012). Concordância verbal e variação: um estudo descritivocomparativo do português brasileiro e do português europeu. Tese de doutorado, Universidade Estadual Paulista - UNESP/Araraquara. 
Monte, A. (2015). O estatuto variável da concordância verbal de terceira pessoa do plural no PB e no PE. Cuadernos de la ALFAL 1(7), 124-143.

Monteiro, J. L. (2002). Morfologia Portuguesa (4 ed.). Campinas: Pontes Editores.

Mota, M. A. (2013). Variant patterns of subject-verb agreement in portuguese: morphological and phonological issues. Journal of Portuguese Linguistics 12, 209-234.

Mota, M. A. (2015). Para uma tipologia da concordância sujeito-verbo, em português falado: contributos do português de Luanda e de Cabo Verde. Cuadernos de la ALFAL 1(7), 17-35.

Mufwene, S. (2001). The Ecology of Language Evolution. Cambridge: Cambridge University Press.

Mufwene, S. (2008). Language Evolution: Contact, Competition and Change. New York: Continuum International Publishing Group.

Mussa, A. (1991). O papel das línguas africanas na história do português do brasil. Dissertação de mestrado, UFRJ.

Naro, A. J. (1981). The social and structural dimensions of syntactic change. Language 57, 63-98.

Naro, A. J. \& M. M. P. Scherre (2007). Origens do português brasileiro, Capítulo Concordância variável em português: a situação no Brasil e em Portugal, pp. 49-69. São Paulo: Parábola Editorial.

Negrão, E. \& E. Viotti (2008). África no Brasil: a formação da língua portuguesa, Capítulo Estratégias de impessoalização no português brasileiro, pp. 179-203. São Paulo: Contexto.

Negrão, E. \& E. Viotti (2010). A estrutura sintática das sentenças absolutas no português brasileiro. Linguística ALFAL 23, 61-82.

Negrão, E. \& E. Viotti (2011). Portugais et langues africaines. Études afrobrésiliennes., Capítulo Epistemological aspects of the study of the participation of African languages in Brazilian Portuguese., pp. 13-44. Paris:Karthala.

Negrão, E. V. \& E. Viotti (2012). Em busca de uma história linguística. Revista Estudos da Linguagem 20 2, 309-342. 
Negrão, E. V. \& E. Viotti (2014). Contato entre o quimbundo e português clássico: impactos na gramática de impessoalização do português brasileiro e angolano. Linguística 30, 289-330.

Neves, D. B. A. (2014). Uma perspectiva comparada entre nomes coletivos e plurais do PB. Monografia de final de curso, Universidade de Brasília.

Newman, P. (1980). The Classification of Chadic within Afroasiatic. Leiden: Universitaire Press.

Ngunga, A. (2002). Elementos de Gramática da língua yao. Maputo: Imprensa Universitária.

Nina, T. d. J. C. (1980). Concordância nominal/verbal do analfabeto na microrregião de bragantina. Dissertação de mestrado, Instituto de Letras e Artes, Pontifícia Universidade Católica/RS.

Oliveira, K. (2008). O verso e o reverso: redução de ditongos e ditongação em textos escritos por negros no Brasil oitocentista. SIGNUM: Estudos da Linguagem 2(11), 155-175.

Oliveira, K. \& T. Lobo (Eds.) (2009). África à vista: dez estudos sobre o português escrito por africanos no Brasil do século XIX. Salvador: EDUFBA.

Oliveira, K., J. Soledade, \& V. d. S. Santos (2009). África à vista: Dez estudos sobre o português escrito por africanos no Brasil do século XIX, Capítulo Concordância Nominal: cenas da variação em palcos do século XIX, pp. 255-316. Salvador: EDUFBA.

Oliveira, M. d. S. (2005). Concordância verbal de terceira pessoa do plural em vitória da conquista: variação estável ou mudança em progresso? Dissertação de mestrado, Instituto de Letras, Universidade Federal da Bahia.

Olsemann, A. (2007). A ambiguidade semântica do coletivo em processos de referenciação. Dissertação de mestrado, Universidade Federal do Paraná.

Oosterbeek, L. \& M. d. G. O. Reis (2012). Terras de preto em terras da santa: Itamatatiua e as suas dinâmicas quilombolas. Cadernos de Pesquisa 19, 7-15.

Parkvall, M. \& L. Álvarez López (2003). Português vernáculo brasileiro e a hipótese da semi-crioulização. Revista da Abralin 2, 111-152. 
Pereira, C. C. M. (2011). Mitos da cultura africana: elementos de informação e preservação da memória na comunidade quilombola alcantarense de itamatatiua. Dissertação de mestrado, Universidade Federal da Paraíba.

Pereira Júnior, D. (2009). Quilombos de Alcântara: território e conflito — intrusamento do território das comunidades quilombolas de Alcântara pela empresa binacional Alcântara Cyclone Space. Manaus: Editora da Universidade Federal do Amazonas.

Pereira Júnior, D. (2012). Territorialidades e identidades coletivas: uma etnografia de terra de santa na baixada maranhense. Dissertação de mestrado, Universidade Federal da Bahia.

Perini, M. A. (2011). Os contatos linguísticos no Brasil, Capítulo Quadro geral do português do Brasil hoje, pp. 139-156. Belo Horizonte: Editora UFMG.

Petter, M. (2002). História do saber lexical e constituição de um léxico brasileiro, Capítulo Termos de origem africana no léxico do português do Brasil, pp. 119 - 141. São Paulo: Humanitas/FFLCH/USP.

Petter, M. (2015). Introdução à Linguística Africana, Capítulo A classificação das línguas da África, pp. 49-85. São Paulo: Editora Contexto.

Petter, M. M. T. Relatório científico apresentado à FAPESP. Projeto Vestígios de Dialetos Crioulos de Base Lexical Portuguesa em Comunidades AfroBrasileiras Isoladas.

Petter, M. M. T. (1999). Lenguas criollas de base lexical española y portuguesa., Capítulo A linguagem do Cafundó: crioulo ou anticrioulo?, pp. 101-118. Vervuert: Iberoamericana.

Petter, M. M. T. (2008). Variedades Linguísticas em Contato: Português Angolano, Português Brasileiro e Português Moçambicano. Tese de livre-docência, Universidade de São Paulo.

Petter, M. M. T. (2011). Os contatos linguísticos no Brasil, Capítulo A influência das línguas africanas no português brasileiro, pp. 255-274. Belo Horizonte: Editora UFMG.

Petter, M. M. T. (2014). História Social da Lingua Nacional 2: Diáspora Africana, Capítulo Línguas africanas e línguas do tráfico, pp. 345-347. Rio de Janeiro: Editora NAU. 
Petter, M. M. T. \& D. Zanoni (2005). Quilombos do Vale do Ribeira: variação e mudança na concordância de gênero e número. Papia-Revista Brasileira de Estudos Crioulos e Similares 1(15), 61-71.

Prado Junior, C. (1979). Evolução política do Brasil e outros estudos. São Paulo: Brasiliense.

Prazeres [Maranhão], F. F. d. N. S. d. (1891). Poranduba maranhense ou relação histórica da província do Maranhão [...] com [...] um dicionario abreviado da lingua geral do Brazil. Revista Trimestral do Instituto Historico e Geográfico Brazileiro 54, 4-277.

Queiroz, S. (1998). Pé preto no barro branco: a lingua dos negros da Tabatinga. Belo Horizonte: Editora da UFMG.

Raimundo, J. (1933). O Elemento Afro-Negro na Lingua Portuguesa. Rio de Janeiro: Renascença Editora.

Raposo, E. (1987). Case theory and Infl-to-Comp: The inflected infinitive in European Portuguese. Linguistic Inquiry 18, 85-109.

Raso, T., H. Mello, \& C. V. Altenhofen (2011). Os contatos linguísticos no Brasil, Capítulo Os contatos linguísticos e o Brasil: Dinâmicas pré-históricas, históricas e sociopolíticas, pp. 13-56. Belo Horizonte: Editora UFMG.

Reis, J. J. \& F. d. S. Gomes (1996). Liberdade por um fio: história dos quilombos no Brasil, Capítulo Introdução: uma história de liberdade, pp. 9-25. São Paulo: Companhia das Letras.

Ribeiro, J. (1897). Diccionario grammatical. Rio de Janeiro/São Paulo: Livraria Clássica/Francisco Alves.

Rodrigues, A. C. S. (1987). A concordância verbal no português popular em São Paulo. Tese de doutorado, Faculdade de Filosofia, Letras e Ciências Humanas, Universidade de São Paulo.

Rodrigues, D. A. (1997). A concordância verbal na fala urbana de rio branco. Dissertação de mestrado, Instituto de Estudos da Linguagem, Universidade Estadual de Campinas.

Rodrigues, N. (1932, [1890 - 1905]). Os africanos no Brasil (1977 ed.). São Paulo: Nacional. Notas bibliográficas de Fernando Sales. 
Rubio, C. F. (2012). Padrões de concordância verbal e alternância pronominal no português brasileiro e no português europeu: estudo sociolinguistico comparativo. São Paulo: Cultura Acadêmica.

Russo, A. M. (2009). Aspectos semânticos, conceituais e morfo-sintáticos das categorias nominais. Dissertação de mestrado, Departamento de Linguística da Faculdade de Filosofia, Letras e Ciências Humanas da Universidade de São Paulo.

Said Ali, M. (1964). Gramática secundária e gramática histórica da língua portuguesa. Brasília: Editora Universidade de Brasília.

Salles, V. (1971). O negro no Pará, sob o regime da escravidão. Rio de Janeiro: Fundação Getúlio Vargas; Belém: Universidade Federal do Pará.

Santos, M. J. V. (1983). A balaiada e a insurreição de escravos no Maranhão. São Paulo: Ática.

Scherre, M. (1988). Reanálise da concordância nominal em português. Tese de doutorado, Universidade Federal do Rio de Janeiro.

Scherre, M. \& A. J. Naro (1997). Diversidade linguística no Brasil, Capítulo A concordância de número no português do Brasil - um caso típico de variação inerente., pp. 93-114. João Pessoa: Idéias.

Scherre, M. M. (1994). Aspectos da concordância de número no português do Brasil. Revista Internacional de Lingua Portuguesa (RILP) - Norma e variação do Português. Associação das Universidades de Lingua Portuguesa 12, 37-49.

Scherre, M. M. (2001). Phrase-level parallelism effect on noun phrase number agreement. Language Variation and Change 13(1), 91-107.

Scherre, M. M. \& A. J. Naro (2010). Grammatical constraints and social factors in subject-verb agreement in Brazilian Portuguese. University of Pennsylvania Working Papers in Linguistics 16(2), 165-71.

Scherre, M. M. P. \& A. J. Naro (1998). Dialettologia, geolinguistica, sociolinguistica (Atti del XXI Congresso Internazionale di Linguistica e Filologia Romanza), Volume 5, Capítulo Sobre a concordância de número no português falado no Brasil, pp. 509-523. Tübingen: Max Niemeyer Verlag. Centro di Studi Filologici e Linguistici Siciliani, Universitá di Palermo. 
Silva, A. d. (2004). A leitura e a compreensão da anáfora conceitual. Tese de doutorado, Instituto de Estudos da Linguagem da Universidade Estadual de Campinas.

Silva, C. R. T., M. D. Moura, \& M. S. d. Cerqueira (2012). Programa Minimalista em foco: princípios e debates, Capítulo Entendendo a concordância sob o viés minimalista, pp. 237-270. Curitiba: Editora CRV.

Silva, G. P. P. (2013). Produção intelectual, movimento social e conflitos: o mabe e a luta em defesa da territorialidade. Dissertação de mestrado, Universidade Estadual do Maranhão.

Silva, J. A. A. d. (2005). A concordância verbal de terceira pessoa do plural no português popular do Brasil: um panorama sociolingüístico de três comunidades do interior do Estado da Bahia. Tese de doutorado, Universidade Federal da Bahia, Instituto de Letras.

Silva, J. A. A. d. \& D. d. S. Santos (2014). Variação e mudança: Análise empírica da concordância verbal na terceira pessoa do plural (P6) em Vitória da Conquista - BA. Estudos da Lingua(gem) 12(2), 73-88.

Silva, T. C., M. S. Fonseca, \& M. Cantoni (2012). A redução do ditongo [ãw] postônico na morfologia verbal do português brasileiro: uma abordagem baseada no uso. Letras de Hoje 47, 283-292.

Soares, L. Y. d. S. (2015). A redução do ditongo nasal átono final na cidade de uberlândia. Dissertação de mestrado, Universidade Federal de Uberlândia.

Souza, C. B. (2011). A concordância verbal no português falado em Salvador: uma realidade linguística bipolarizada. Papia: Revista Brasileira de Estudos e Similares 2(21), 183-93.

Souza, P. D. d. S. (2005). Concordância verbal em português: o que nos revela o período arcaico? Dissertação de mestrado, Universidade Federal da Bahia.

Stroud, C. \& G. Perpétua (Eds.) (1997). Panorama do português oral de Maputo: A Construção de um Banco de Erros, Volume II. Estocolmo: Stockholm Institute of Education - GOTAB.

van der Veen, L. J. (2003). The Bantu Languages, Capítulo The B30 language group, pp. 371-391. Nova York: Routledge. 
Vianna Filho, L. (1946). O negro na Bahia. São Paulo: J. Olympo.

Vieira, S. R. (1997). A não-concordância em dialetos populares: uma regra variável. Revista Graphos 1(2), 115-133.

Vieira, S. R. (2015a). A concordância verbal em variedades do português: a interface fonética-morfossintaxe, Capítulo A interface morfossintaxe-fonética na variação da concordância: primeiras contribuições, pp. 17-28. Rio de Janeiro: Vermelho Marinho.

Vieira, S. R. (2015b). Padrões de concordância de terceira pessoa do plural no português: um balanço das contribuições do projeto 21 da ALFAL. Cuadernos de la ALFAL 1(7), 107-123.

Vieira, S. R. \& A. Bazenga (2013). Patterns of third person verbal agreement. Journal of Portuguese Linguistics 12, 7-50.

Vieira, S. R. \& A. M. Bazenga (2015). A concordância verbal em variedades do português: a interface fonética-morfossintaxe, Capítulo A concordância de terceira pessoa do plural: padrões em variedades do português, pp. 29 75. Rio de Janeiro: Vermelho Marinho.

Vieira, S. R., S. F. Brandão, \& D. K. Gomes (2015). A concordância verbal em variedades do português: a interface fonética-morfossintaxe, Capítulo A expressão fonética de terceira pessoa do plural no português do Brasil: uma agenda de pesquisa para o tratamento da variável saliência fônica, pp. 104-147. Rio de Janeiro: Vermelho Marinho.

Vilela, M. (1974). Considerações gerais sobre o género: o género dentro das categorias gramaticais. Revista da Faculdade de Letras - Filologia 1, 139-150.

Viveiros, J. (1954). História do Comércio do Maranhão: 1612 - 1895. São Luís: Associação Comercial do Maranhão.

Vogt, C. \& P. Fry (1996). Cafundó: A África no Brasil. Linguagem e sociedade. São Paulo: Unicamp/Companhia das Letras.

Welchen, D. (2009). Pelotas/RS e a concordância de terceira pessoa do plural. Tese de doutorado, Instituto de Letras, Universidade Federal do Rio Grande do Sul.

Welchen, D. (2015). A concordância verbal de terceira pessoa do plural em Pelotas/RS. Revista Linguas E Letras - Unioeste 16(32), 374-393.

Wetzels, W. L. (2000). Comentários sobre a estrutura fonológicas dos ditongos nasais no português do Brasil. Revista de Letras 1/2(22), 25-30. 
Anexo I - Mapas 


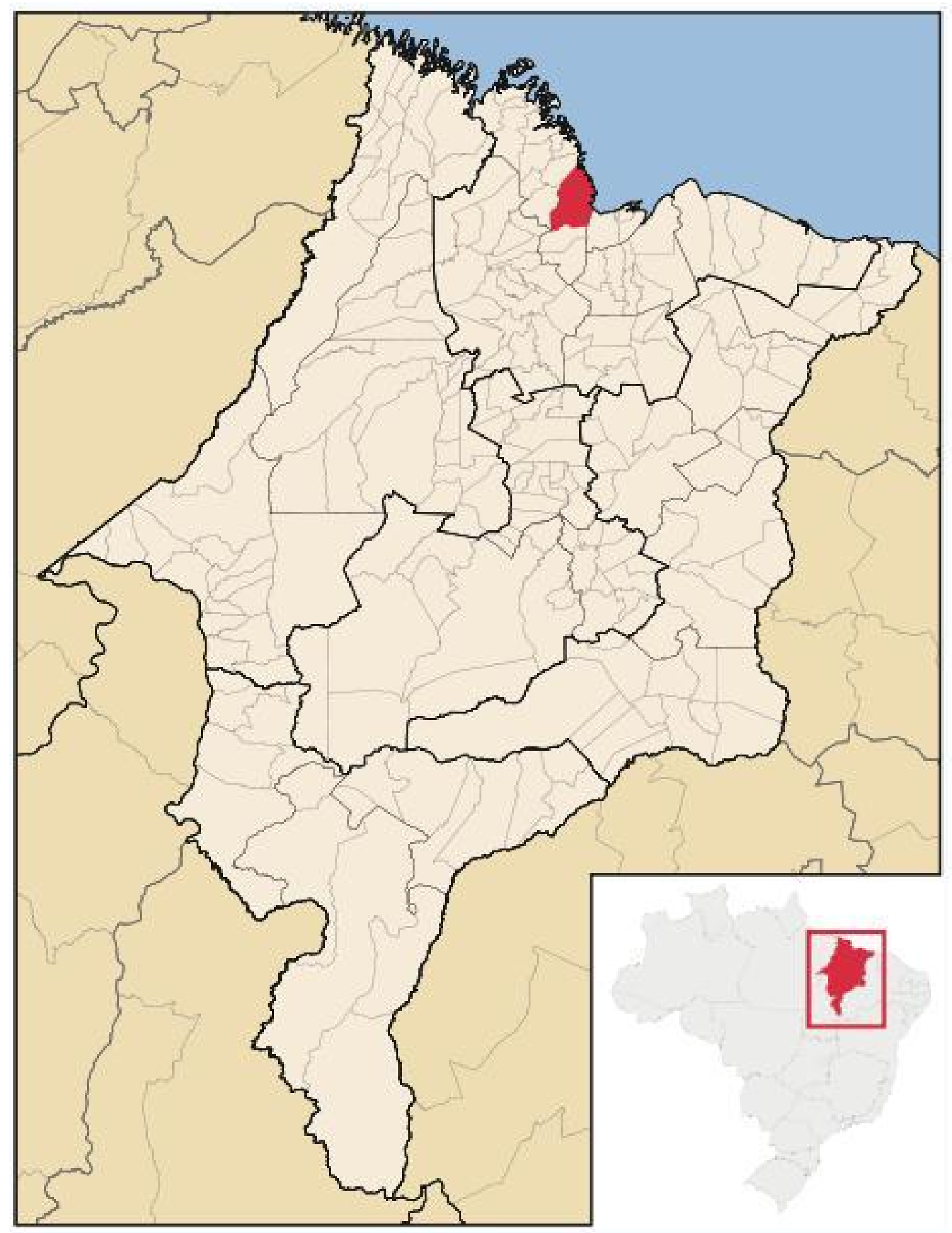

Figura 1: Localização de Alcântara, Maranhão. 


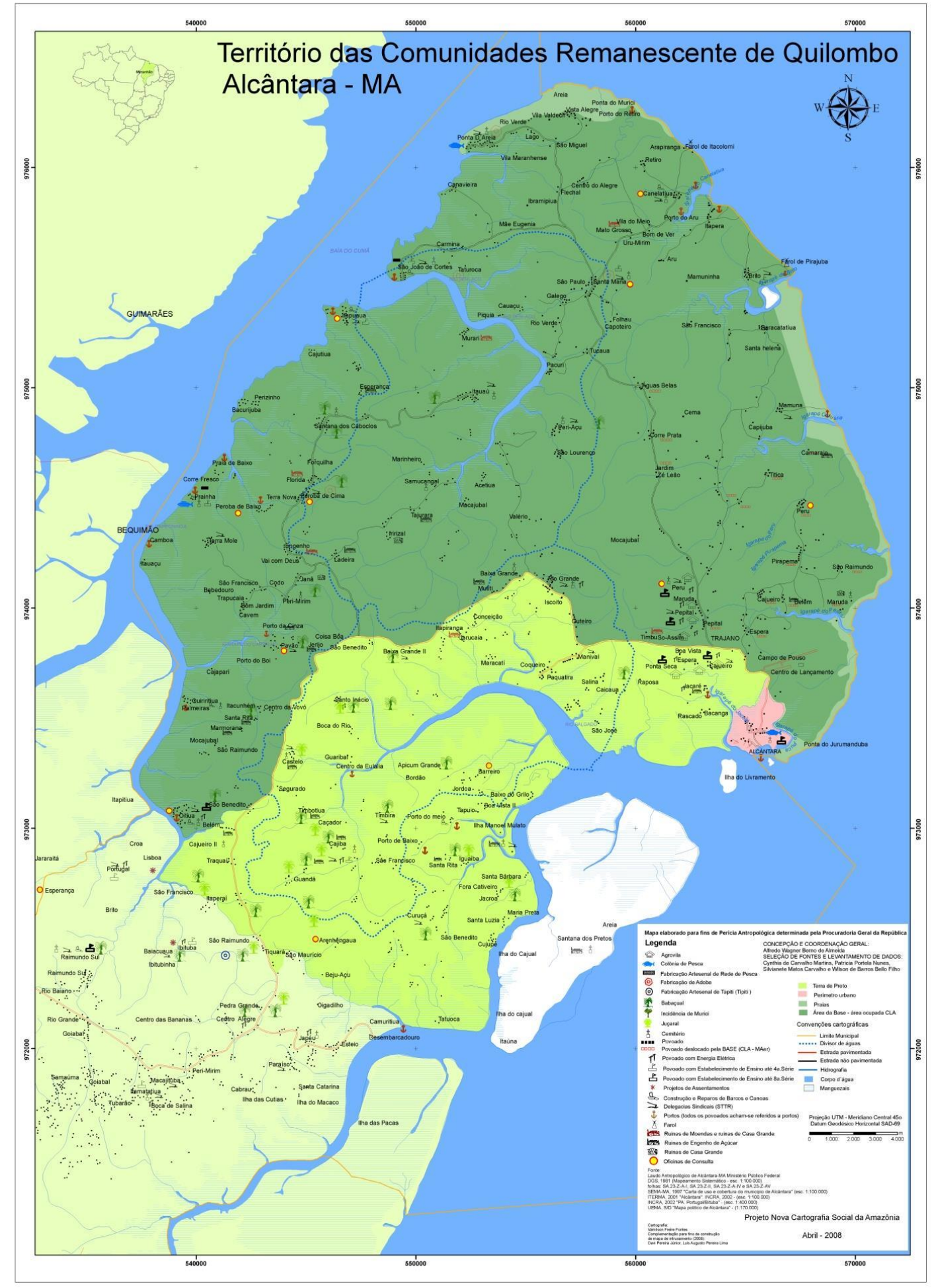

Figura 2: Território das Comunidades Remanescentes de Quilombos em Alcântara/MA. 


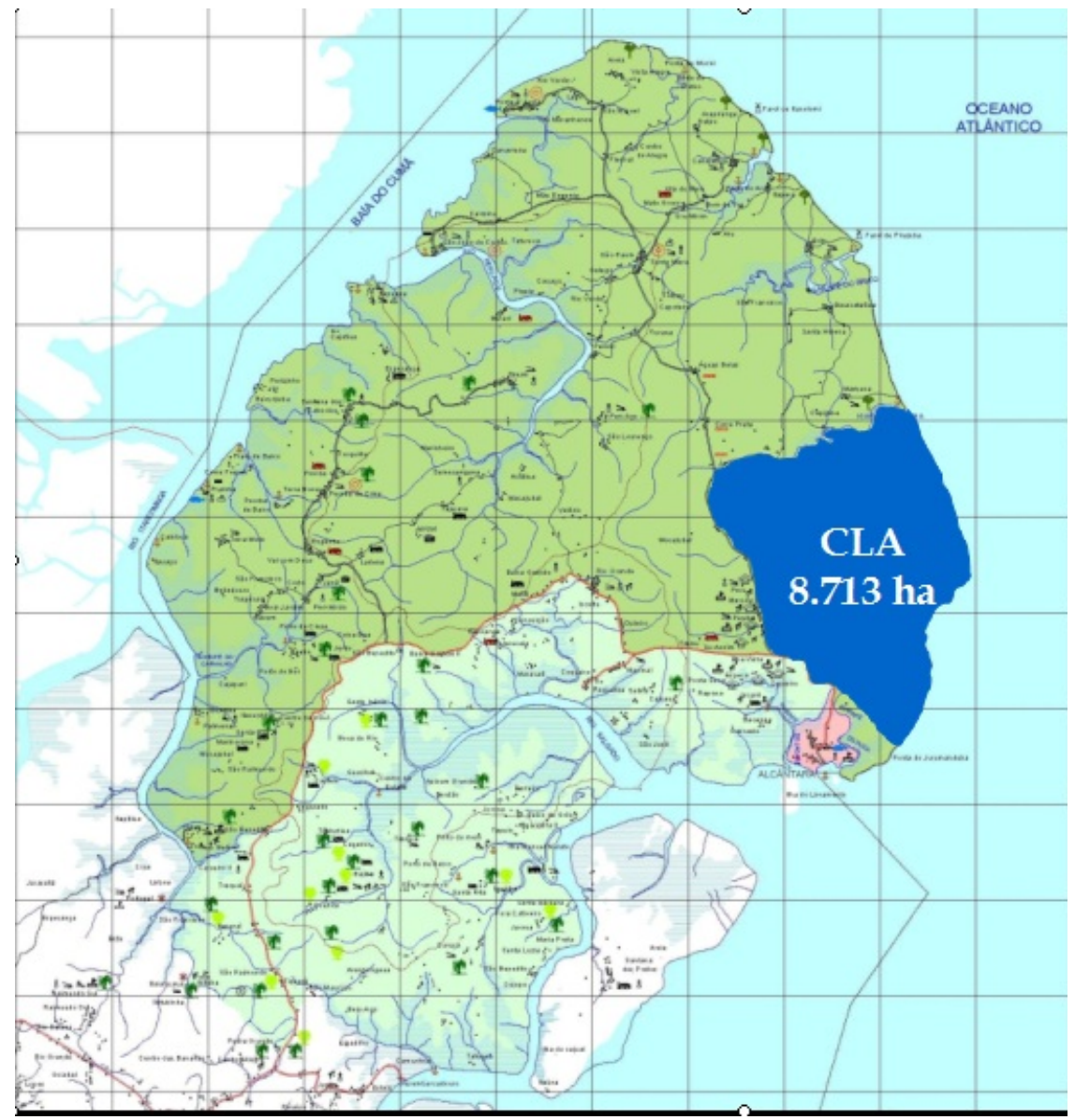

Figura 3: Área do Centro de Lançamento, Alcântara/MA 


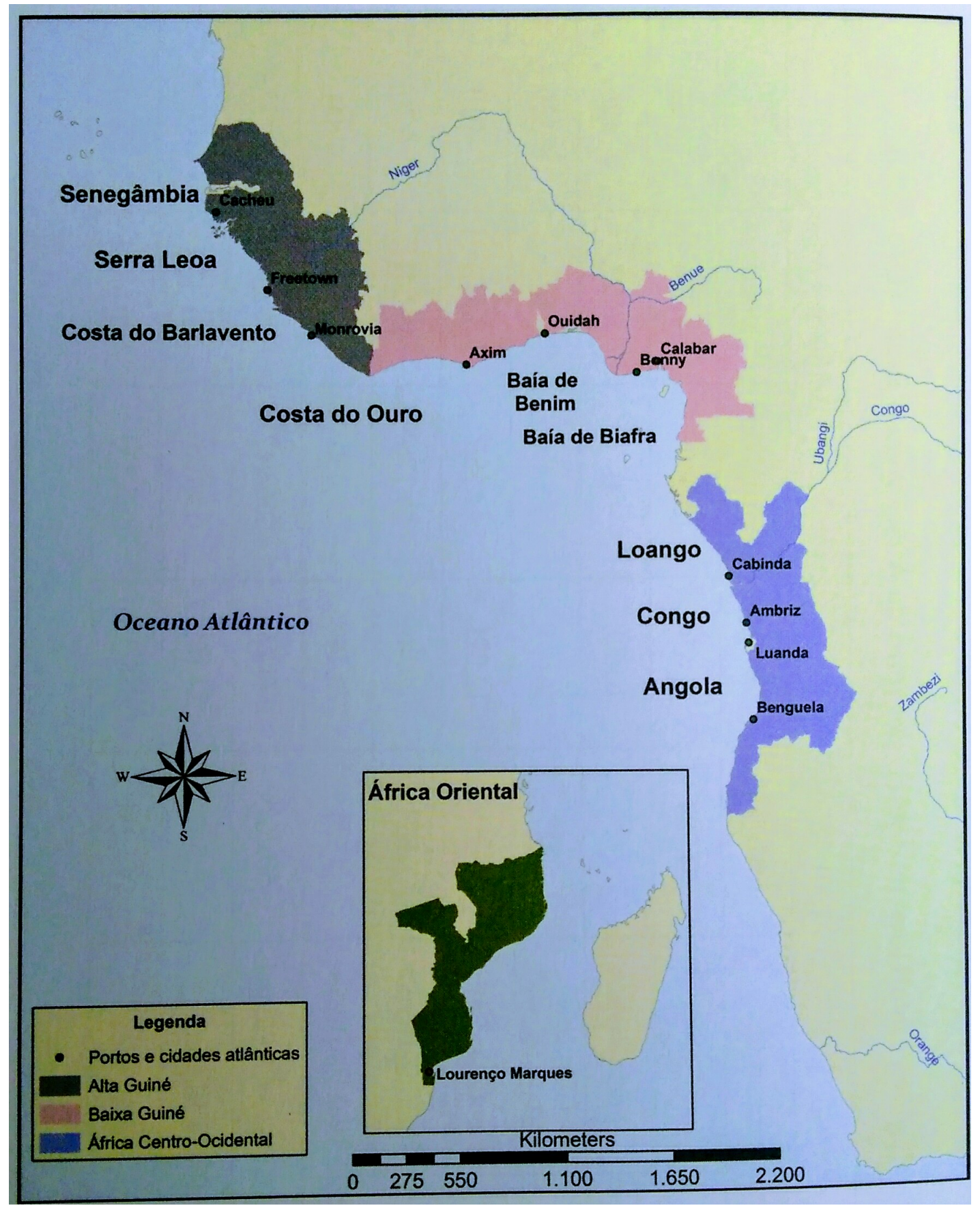

Figura 4: Tráfico de escravos: regiões e portos.

Fonte:Almeida (2014:358). 


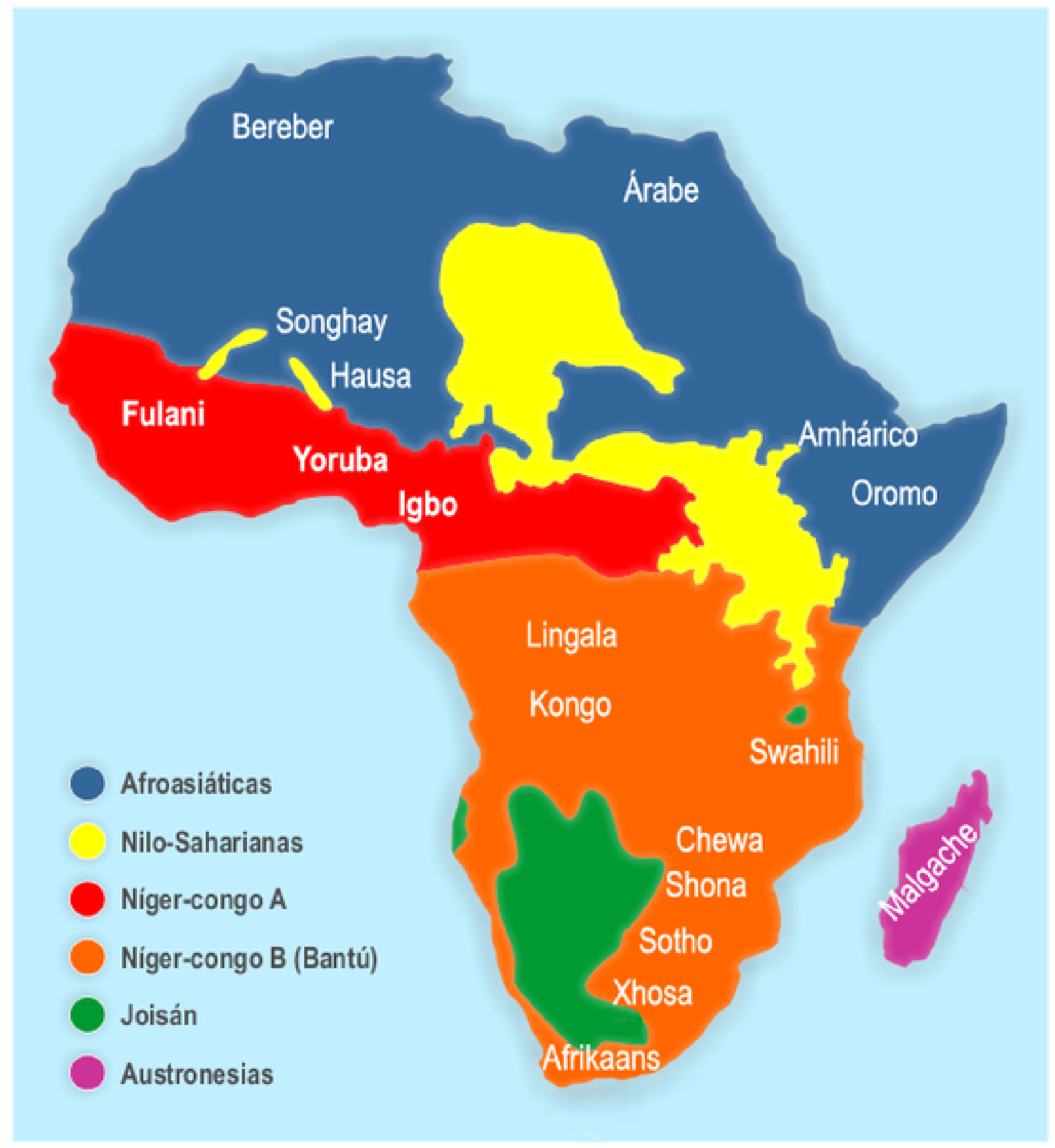

Figura 5: Línguas da África: troncos linguísticos.

Fonte: pt.wikipedia.org 


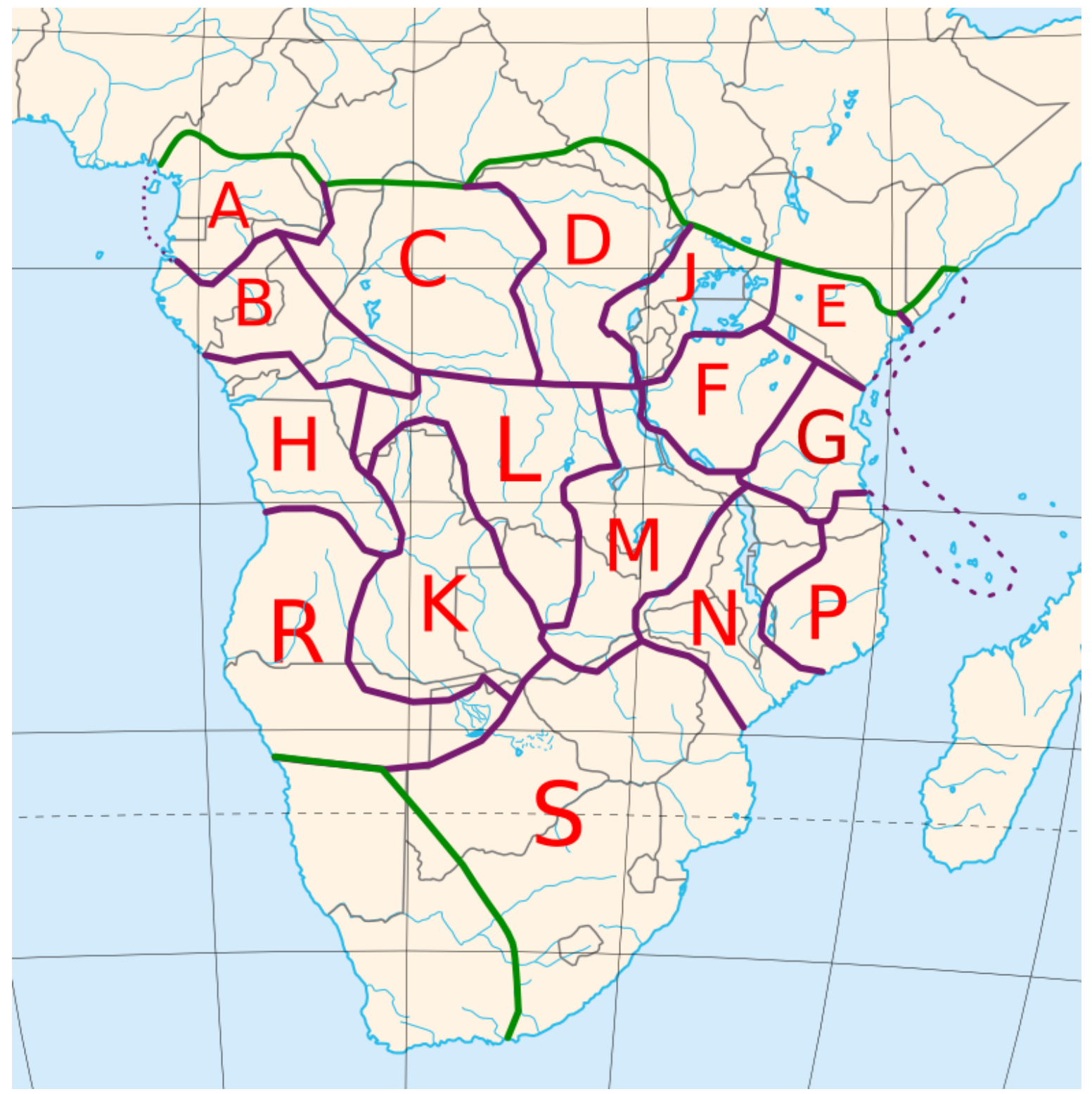

Figura 6: Localização aproximada das zonas geográficas de acordo a classificação de Guthrie. Fonte: https://en.wikipedia.org 


\section{Anexo II - Carta de Alcântara sobre a cessão da Base Espacial aos EUA}




\title{
Carta de Alcântara sobre a cessão da Base Espacial aos EUA
}

\author{
SINDICATO DOS TRABALHADORES RURAIS AGRICULTORES E AGRICULTORAS \\ FAMILIARES DE ALCÂNTARA - STTR. \\ MOVIMENTO DOS ATINGIDOS PELA BASE ESPACIAL DE ALCÂNTARA - MABE \\ MOVIMENTO DE MULHERES TRABALHADORAS DE ALCÂNTARA - MOMTRA \\ CARTA AO POVO BRASILEIRO \\ A BASE ESPACIAL DE ALCÂNTARA É NOSSA E DEVE SERVIR SOBERANA E \\ DEMOCRATICATICAMENTE AO POVO BRASILEIRO.
}

Alcântara/MA, 19/02/2017

O Sindicato dos Trabalhadores Rurais Agricultores e Agricultoras Familiares de Alcântara (STTR/Alcântara), o Movimento dos Atingidos pela Base Espacial de Alcântara (MABE) e o Movimento de Mulheres Trabalhadoras de Alcântara, organizações sociais que historicamente se colocam na luta e defesa do território quilombola de Alcântara REPUDIAM veementemente os fatos noticiados recentemente por diversos meios de comunicação sobre a negociação orquestrada pelo então titular do Ministério das Relações Exteriores do Brasil cuja finalidade é a cessão da Base Espacial de Alcântara aos Estados Unidos da América, pelos fatos e razões a seguir:

1. Como é de amplo e irrestrito conhecimento de toda a comunidade nacional e internacional o movimento quilombola de Alcântara, representado pelas instituições acima, sempre se colocou na dianteira do debate crítico acerca da política espacial brasileira, desenvolvida a partir da Base Espacial de Alcântara;

2. Sobretudo porque toda e qualquer intervenção ali produzida reverbera no cotidiano das comunidades quilombolas de Alcântara;

3. O protagonismo histórico da luta do movimento quilombola de Alcântara, cuja fala há mais de três décadas ecoa na arena pública do embate político, agora com o mesmo vigor e entusiasmo, e também lançando mão da lucidez política necessária, ergue-se na defesa da soberania do povo brasileiro ao se posicionar absolutamente contrário a cessão da Base Espacial de Alcântara aos Estados Unidos da América. A Base espacial é um patrimônio do povo brasileiro e para este deve estar a serviço!

4. Como é sabido, sempre questionamos em diversos espaços e fóruns, inclusive acadêmicos, o modelo de desenvolvimento adotado pelo governo brasileiro, na condução da política espacial brasileira. Pois, as propostas até então apresentadas sempre se convergem na perda do nosso território e dos direitos fundamentais dele correlatos;

5. Razão pela qual, diversas ações judiciais tramitam nos tribunais nacionais contra o governo brasileiro, e mesmo nos tribunais internacionais a exemplo das ações em curso da Comissão Interamericana de Direitos Humanos e na Organização Internacional do Trabalho, denunciando as violações de direitos perpetradas pelo governo brasileiro no comando da política espacial em Alcântara;

6. Neste contexto, destacamos o que nos é mais caro: o não cumprimento pelo Estado brasileiro da norma constitucional dispensada no artigo 68 do Ato das Disposições Constitucionais 
Transitórias do texto constitucional de 1988, isto é, a não titulação do território quilombola de Alcântara, cujo processo se arrasta desde o final da década de 1990, sem que até o momento tenha encontrado uma solução que assegure os direitos das famílias quilombolas;

7. O conflito social de Alcântara coloca dois grandes protagonistas em posições opostas do debate, sem quaisquer prejuízos dos demais atores envolvidos. De um lado o governo brasileiro que sustenta o atual modelo de desenvolvimento da política espacial, e de outro lado, as comunidades quilombolas que têm diariamente seus direitos territoriais ameaçados em detrimento de um equivocado programa espacial que já demonstrara por diversos e lamentáveis acidentes e fracassados acordos internacionais, não funcionar;

8. Apesar disso, NÃO SOMOS CONTRA A BASE ESPACIAL! Nutrimos o mais claro entendimento sobre sua importância estratégica para o desenvolvimento científico e tecnológico do Brasil e para o povo brasileiro. A Base Espacial constitui patrimônio científico irrenunciável do povo brasileiro;

9. O seu uso e o seu desenvolvimento, devem servir exaustivamente aos interesses nacionais e da soberania científica do povo brasileiro, colocando o Brasil na linha de frente da exploração da tecnologia espacial;

10.Entregá-la aos interesses estrangeiros significa, no nosso entender, renunciar a todo um esforço e investimento nacional, ainda que tímido, que já fora realizado ferindo, assim, nossa soberania. A proposta encabeçada pelo atual e ilegítimo governo afronta a soberania e autonomia científica do povo brasileiro;

11.E mais, os povos quilombolas gozam do direito constitucional a autodeterminação sobre seus territórios, logo, a proposta em questão vai de encontro a Tratados e Convenções internacionais a que o Brasil é signatário, a exemplo a Convenção 169 da OIT sobre Povos Indígenas e Tribais;

12.No mais, a cessão da Base Espacial de Alcântara aos Estados Unidos ou a qualquer outro país implica na afronta à autodeterminação do povo quilombola de Alcântara na gestão do seu território. E disso não abrimos mão!

13.Mobilizaremos todos os meios e esforços que tiverem ao alcance para impedir o avanço dessa proposta neoliberalista que na prática fere a soberania do povo brasileiro e de longe a autodeterminação das comunidades quilombolas de Alcântara;

14.Defendemos que a gestão e o desenvolvimento da política espacial brasileira sejam exclusivamente realizados pelo governo brasileiro, em parceria fundamental da comunidade cientifica brasileira. Só assim teremos um programa aeroespacial sólido, soberano e alicerçado nos valores da democracia, inclusão social e do respeito aos direitos territoriais das comunidades quilombolas de Alcântara;

15.Assim, convocamos toda sociedade brasileira a lutar para impedir o avanço da proposta de ceder/alugar/privatizar a Base Espacial de Alcântara aos interesses americanos ou a qualquer outro país. É preciso resistir, tal qual o fizemos à época da ALCA e do famigerado acordo Brasil - EUA de salvaguarda tecnológica no início da década 2000;

16.A BASE ESCPACIAL é do povo brasileiro, e dever servir aos interesses soberanos e democráticos do povo brasileiro! A tecnologia e o desenvolvimento científico devem estar a serviço dos direitos do povo brasileiro. 
Sindicato dos Trabalhadores e Trabalhadoras Rurais de Alcântara - STTR/Alcântara Movimento dos Atingidos pela Base Espacial de Alcântara - MABE Movimento de Mulheres Trabalhadoras de Alcântara - MOMTRA 